Prepared in cooperation with the New Jersey Department of Environmental Protection

\title{
Water-Level Conditions in the Confined Aquifers of the New Jersey Coastal Plain, 2008
}

Scientific Investigations Report 2013-5232 



\section{Water-Level Conditions in the Confined Aquifers of the New Jersey Coastal Plain, 2008}

By Vincent T. DePaul and Robert Rosman

Prepared in cooperation with the

New Jersey Department of Environmental Protection

Scientific Investigations Report 2013-5232 


\title{
U.S. Department of the Interior SALLY JEWELL, Secretary
}

\section{U.S. Geological Survey Suzette M. Kimball, Acting Director}

\author{
U.S. Geological Survey, Reston, Virginia: 2015
}

For more information on the USGS - the Federal source for science about the Earth, its natural and living resources, natural hazards, and the environment, visit http://WWw.usgs.gov or call 1-888-ASK-USGS

For an overview of USGS information products, including maps, imagery, and publications, visit http://WwW.usgs.gov/pubprod

To order this and other USGS information products, visit http://store.usgs.gov

Any use of trade, firm, or product names is for descriptive purposes only and does not imply endorsement by the U.S. Government.

Although this information product, for the most part, is in the public domain, it also may contain copyrighted materials as noted in the text. Permission to reproduce copyrighted items must be secured from the copyright owner.

Suggested citation:

DePaul, V.T., and Rosman, Robert, 2015, Water-level conditions in the confined aquifers of the New Jersey Coastal Plain, 2008: U.S. Geological Survey Scientific Investigations Report 2013-5232, 107 p., 9 pl., http://dx.doi. org/10.3133/sir20135232.

ISSN 2328-0328 (online) 


\section{Acknowledgments}

The authors are grateful to the many well owners for allowing access to their wells and to the water purveyors and staff for adjusting withdrawal schedules and assisting in the collection of water-level measurements. The authors also wish to thank Nicholas Smith, Walter Jones, Richard Walker, Donald Rice, Stephen Cauller, and Glen Carleton of the U.S. Geological Survey (USGS) for their assistance in data collection and Stewart Lovell and William Cocke of the Delaware Department of Natural Resources and Environmental Control for facilitating the collection of water-level data in Delaware. Critical reviews of the manuscript were provided by Glen Carleton and Edward Bugliosi of the USGS. Frederick Sickels and Diane Zalaskus of the New Jersey Department of Environmental Protection are gratefully acknowledged for their continued support of this program.

\section{Contents}

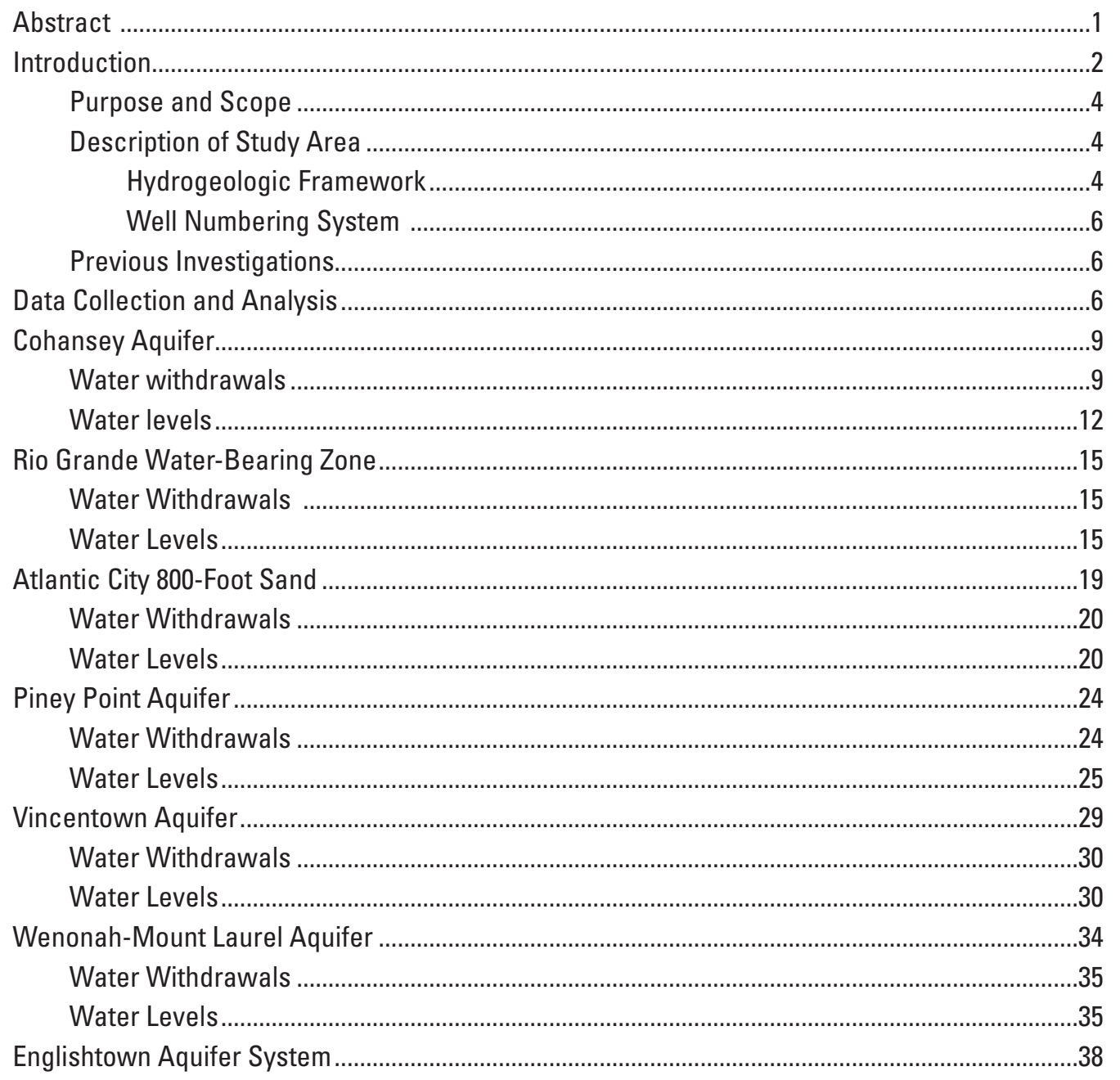




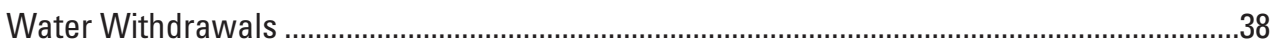

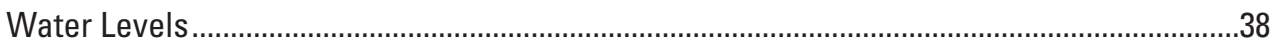

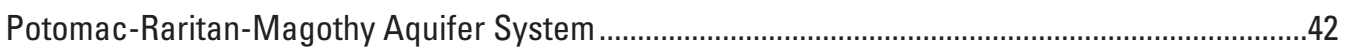

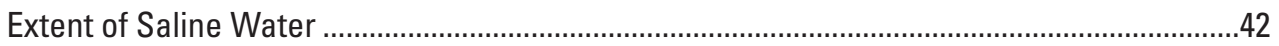

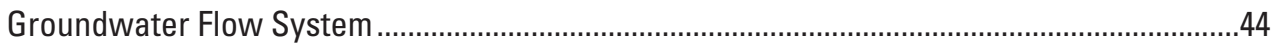

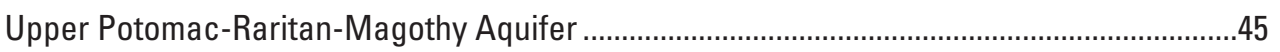

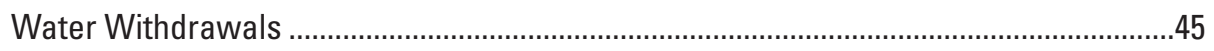

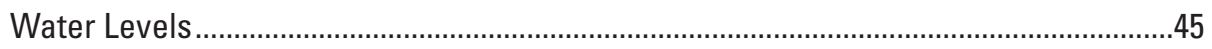

Middle Potomac-Raritan-Magothy Aquifer.....................................................................52

Water Withdrawals …..........................................................................................

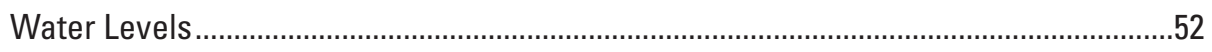

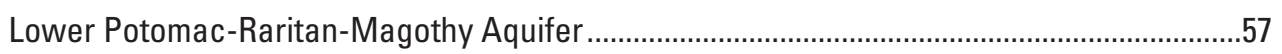

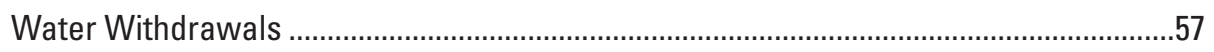

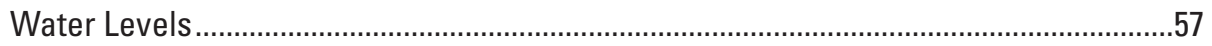

Potentiometric Heads in Relation to the Tops of Aquifers .........................................................60

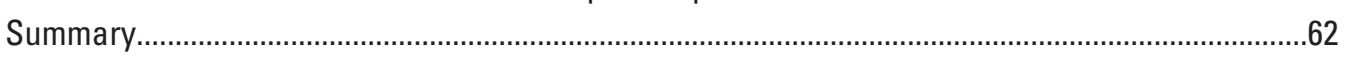

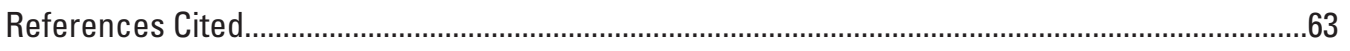

Appendixes 1-10.

1-1. Water-level data for wells screened in the confined Cohansey aquifer, New Jersey Coastal Plain, 1978-2008......................................................................68

1-2. Water-level data for wells screened in the Rio Grande water-bearing zone, New Jersey Coastal Plain, 1978-2008 ...................................................................69

2. Water-level data for wells screened in the Atlantic City 800-foot sand, New Jersey Coastal Plain, 1978-2008.

3. Water-level data for wells screened in the Piney Point aquifer, New Jersey Coastal Plain, 1978-2008.

4. Water-level data for wells screened in the Vincentown aquifer, New Jersey Coastal Plain, 1978-2008..

5. Water-level data for wells screened in the Wenonah-Mount Laurel aquifer, New Jersey Coastal Plain, 1978-2008.

6. Water-level data for wells screened in the Englishtown aquifer system, New Jersey Coastal Plain, 1978-2008

7. Water-level data for wells screened in the Upper Potomac-Raritan-Magothy aquifer, New Jersey Coastal Plain, 1978-2008

8. Water-level data for wells screened in the Middle and undifferentiated

Potomac-Raritan-Magothy aquifer, New Jersey Coastal Plain, 1978-2008

9. Water-level data for wells screened in the Lower Potomac-Raritan-Magothy aquifer, New Jersey Coastal Plain, 1978-2008

10-1. Results of the Mann-Kendall trend test on water levels from selected observation wells, New Jersey Coastal Plain, 1978-2008 …………………………………….......104

10-2. Results of the Wilcoxon signed-rank test for paired water levels .................................107 


\section{Plates}

Plates 1-9. Maps showing:

1. Potentiometric surface of the Cohansey aquifer and the Rio Grande water-bearing zone, 2008

2. Potentiometric surface of the Atlantic City 800 -foot sand, 2008

3. Potentiometric surface of the Piney Point aquifer, 2008

4. Potentiometric surface of the Vincentown aquifer, 2008

5. Potentiometric surface of the Wenonah-Mount Laurel aquifer, 2008

6. Potentiometric surface of the Englishtown aquifer system, 2008

7. Potentiometric surface of the Upper Potomac-Raritan-Magothy aquifer, 2008

8. Potentiometric surface of the Middle and undifferentiated Potomac-Raritan-Magothy aquifer, 2008

9. Potentiometric surface of the Lower Potomac-Raritan-Magothy aquifer, 2008

\section{Figures}

1. Map showing location of the study area and generalized representation of simulated prepumping flow in a hydrogeologic section through the Coastal Plain of southern New Jersey...

2. Map showing location and volume of groundwater withdrawals from the confined Cohansey aquifer, southern Cape May County, New Jersey Coastal Plain, 2008

3. Graph showing estimated groundwater withdrawals from the confined Cohansey aquifer in Cape May County, New Jersey Coastal Plain, 1978-2008

4. Map showing water-level changes in the confined Cohansey aquifer, Cape May County, New Jersey Coastal Plain, 2003-2008.

5. Graphs showing water-level hydrographs for selected observation wells screened in the confined Cohansey aquifer, Cape May County, New Jersey Coastal Plain, 1978-2008.

6. Maps showing location and volume of groundwater withdrawals from $A$, the Rio Grande water-bearing zone, $B$, the Atlantic City 800 -foot sand, and $C$, the Piney Point aquifer, New Jersey Coastal Plain, 2008

7. Graphs showing estimated groundwater withdrawals from $A$, the Rio Grande water-bearing zone, $B$, the Atlantic City 800 -foot sand, and $C$, the Piney Point aquifer New Jersey Coastal Plain, 1978-2008.

8. Maps showing groundwater-level changes in $A$, the Rio Grande water-bearing zone, $B$, the Atlantic City 800 -foot sand, and $C$, the Piney Point aquifer, New Jersey Coastal Plain, 2003-2008.

9. Graphs showing water-level hydrographs for selected observation wells screened in the Rio Grande water-bearing zone, New Jersey Coastal Plain, 1978-2008.

10. Graphs showing water-level hydrographs for selected observation wells screened in the Atlantic City 800-foot sand, New Jersey Coastal Plain, 1978-2008.

11. Graphs showing water-level hydrographs for selected observation wells screened in the Piney Point aquifer, New Jersey Coastal Plain, 1978-2008 
12. Graph showing water-level hydrograph for selected observation wells screened in the Piney Point aquifer, Delaware and eastern Maryland, 1978-2008 .....

13. Maps showing location and volume of groundwater withdrawals from $A$, the Vincentown aquifer, $B$, Wenonah-Mount Laurel aquifer, and $C$, the Englishtown aquifer system, New Jersey Coastal Plain, 2008.

14. Graphs showing estimated groundwater withdrawals from $A$, the Vincentown aquifer, $B$, the Wenonah-Mount Laurel aquifer, and $C$, the Englishtown aquifer system, New Jersey Coastal Plain, 1978-2008.

15. Maps showing groundwater level changes in $A$, the Vincentown aquifer, $B$, the Wenonah-Mount Laurel aquifer, and $C$, the Englishtown aquifer system, New Jersey Coastal Plain, 2003 to 2008.

16. Graphs showing water-level hydrographs for selected observation wells screened in the Vincentown aquifer, New Jersey Coastal Plain, 1978-2008.

17. Graph showing water-level hydrographs for selected observation wells screened in the Wenonah-Mount Laurel aquifer in the northern counties of the New Jersey Coastal Plain, 1978-2008.

18. Graph showing water-level hydrographs for selected observation wells screened in the Wenonah-Mount Laurel aquifer in the southern counties of the New Jersey Coastal Plain, 1978-2008.

19. Graphs showing water-level hydrographs for selected observation wells screened in the Englishtown aquifer system, New Jersey Coastal Plain, 1978-2008

20. Map showing area of saline groundwater, Potomac-Raritan-Magothy aquifer system, New Jersey, 2008

21. Maps showing location and volume of groundwater withdrawals from $A$, the Upper Potomac-Raritan-Magothy aquifer, $B$, the Middle Potomac-Raritan-Magothy aquifer, and $C$, the Lower Potomac-Raritan-Magothy aquifer, New Jersey Coastal Plain, 2008

22. Graphs showing estimated groundwater withdrawals from $A$, the Upper PotomacRaritan-Magothy aquifer, $B$, the Middle Potomac-Raritan-Magothy aquifer, and $C$, the Lower Potomac-Raritan-Magothy aquifer, New Jersey Coastal Plain, 1978-2008

23. Maps showing groundwater-level changes in the $A$, Upper Potomac-RaritanMagothy aquifer, $B$, Middle Potomac-Raritan-Magothy aquifer, and $C$, Lower Potomac-Raritan-Magothy aquifer, New Jersey Coastal Plain, 2003-2008 .

24. Graphs showing water-level hydrographs for selected observation wells screened in the Upper Potomac-Raritan-Magothy aquifer in the northern counties, New Jersey Coastal Plain, 1978-2008.

25. Graphs showing water-level hydrographs for selected observation wells screened in the Upper Potomac-Raritan-Magothy aquifer in the southern counties, New Jersey Coastal Plain, 1978-2008.

26. Graphs showing water-level hydrographs for selected observation wells screened in the Middle and undifferentiated Potomac-Raritan-Magothy aquifer in the northern counties, New Jersey Coastal Plain, 1978-2008.

27. Graphs showing water-level hydrographs for selected observation wells screened in the Middle and undifferentiated Potomac-Raritan-Magothy aquifer in the southern counties, New Jersey Coastal Plain, 1978-2008

28. Graphs showing water-level hydrographs for selected observation wells screened in the Lower Potomac-Raritan-Magothy aquifer, New Jersey Coastal Plain, 1978-2008 
29. Graphs showing water-level hydrographs for selected observation wells screened in the Lower Potomac-Raritan-Magothy aquifer, Delaware Coastal Plain, 1978-2008

30. Maps showing available feet of potentiometric head above the top of the $A$, Piney Point aquifer, $B$, Wenonah-Mount Laurel aquifer, and $C$, Englishtown aquifer system, central and southern New Jersey, 2008.

\section{Tables}

1. Geologic and hydrogeologic units of the New Jersey Coastal Plain

2. County prefix codes used in well-numbering systems in New Jersey, Pennsylvania, and Maryland

3. Groundwater withdrawals by county and aquifer from selected confined aquifers of the New Jersey Coastal Plain, 2008

\section{Conversion Factors, Datums, and Abbreviations}

\begin{tabular}{lcl}
\multicolumn{1}{l}{ Inch/Pound to SI } & & \\
\hline \multicolumn{1}{c}{ Multiply } & By & \multicolumn{1}{c}{ To obtain } \\
\hline & Length & \\
\hline foot $(\mathrm{ft})$ & 0.3048 & meter $(\mathrm{m})$ \\
mile $(\mathrm{mi})$ & 1.609 & kilometer $(\mathrm{km})$ \\
\hline & Area & \\
\hline square mile $\left(\mathrm{mi}^{2}\right)$ & 2.590 & square kilometer $\left(\mathrm{km}^{2}\right)$ \\
\hline & Flow rate & \\
\hline gallon per day $($ gal $/ \mathrm{d})$ & 0.003785 & cubic meter per day $\left(\mathrm{m}^{3} / \mathrm{d}\right)$ \\
million gallons per day $(\mathrm{Mgal} / \mathrm{d})$ & 0.04381 & cubic meter per second $\left(\mathrm{m}^{3} / \mathrm{s}\right)$ \\
\hline & Transmissivity & \\
\hline foot squared per day $\left(\mathrm{ft}^{2} / \mathrm{d}\right)$ & 0.09290 & meter squared per day $\left(\mathrm{m}^{2} / \mathrm{d}\right)$ \\
\hline
\end{tabular}

Vertical coordinate information is referenced to the National Geodetic Vertical Datum of 1929 (NGVD 29).

Horizontal coordinate information is referenced to the North American Datum of 1983 (NAD 83).

Altitude, as used in this report, refers to distance above or below the vertical datum.

*Transmissivity: The standard unit for transmissivity is cubic foot per day per square foot times foot of aquifer thickness $\left[\left(\mathrm{ft}^{3} / \mathrm{d}\right) / \mathrm{ft}^{2}\right] \mathrm{ft}$. In this report, the mathematically reduced form, foot squared per day $\left(\mathrm{ft}^{2} / \mathrm{d}\right)$, is used for convenience.

Concentrations of chemical constituents in water are given in milligrams per liter (mg/L). 



\title{
Water-Level Conditions in the Confined Aquifers of the New Jersey Coastal Plain, 2008
}

\author{
by Vincent T. DePaul and Robert Rosman
}

\section{Abstract}

Groundwater-level altitudes in 10 confined aquifers of the New Jersey Coastal Plain were measured and evaluated to provide an overview of regional groundwater conditions during fall 2008. Water levels were measured in more than 900 wells in New Jersey, eastern Pennsylvania, and northern Delaware and potentiometric surface maps prepared for the confined Cohansey aquifer of Cape May County, the Rio Grande water-bearing zone, the Atlantic City 800-foot sand, the Piney Point, Vincentown, and the Wenonah-Mount Laurel aquifers, the Englishtown aquifer system, and the Upper, Middle, and Lower aquifers of the Potomac-Raritan-Magothy aquifer system. In 2008, the highest water-level altitudes were observed in the Vincentown aquifer (median, $78 \mathrm{ft}$ ) and the lowest in the Atlantic City 800-foot sand (median, -45 ft). Persistent, regionally extensive cones of depression were present within the potentiometric surfaces of the Englishtown aquifer system in east-central New Jersey, the Wenonah-Mount Laurel aquifer in east-central and southern New Jersey, the Upper, Middle, and Lower Potomac-Raritan-Magothy aquifers in southern New Jersey, and the Atlantic City 800-foot sand in the southeastern part of the State. Cones of depression in the potentiometric surfaces of the Upper Potomac-Raritan-Magothy and the Piney Point aquifers in east-central and southwestern New Jersey had broadened and deepened since 2003.

Declining water levels in many of New Jersey's confined Coastal Plain aquifers intensified during the late 1970s and early 1980s, prompting the designation of two water-supply Critical Areas by the New Jersey Department of Environmental Protection; Critical Areas 1 and 2 continued to be of concern. To address that concern, water-level changes were assessed in nearly 800 wells measured during the fall of 2003 and 2008, and potentiometric-surface difference maps for each aquifer were constructed and evaluated. In addition, water-level trends were calculated for 77 wells for the periods 2003-8 and 1998-2008 and for 73 wells for the period 1978-2008.

From 2003 to 2008 small to moderate water-level changes were observed in many Coastal Plain aquifers in New Jersey, but in places, groundwater levels continued to decline substantially as a result of pumping. Groundwater levels in the Atlantic City 800-foot sand were lower in 2008 than in 2003; declines were greatest near pumping centers in eastern Atlantic County. Changes were less pronounced in Cape May County where water levels were, on average, 1 to 3 feet (ft) lower than those during the previous study (2003), except near Rio Grande where a localized cone of depression had formed as a result of increased withdrawals. Large and widespread declines occurred in the Piney Point aquifer in Cumberland County where water levels in and around the city of Bridgeton had fallen in excess of $100 \mathrm{ft}$ since 2003 , and by $30 \mathrm{ft}$ to more than $60 \mathrm{ft}$ in surrounding areas. Groundwater levels in the Wenonah-Mount Laurel aquifer and Englishtown aquifer system continued to recover in east-central New Jersey; however, groundwater levels in the Wenonah-Mount Laurel aquifer throughout the southern part of the State continued to decline.

In the Upper Potomac-Raritan-Magothy aquifer, groundwater levels were substantially lower than in 2003 in parts of northern Ocean County but were stable in the area adjacent to Raritan Bay (Critical Area 1), and water levels continued to recover in southern New Jersey. In the Middle PotomacRaritan-Magothy aquifer, water levels rose near Raritan Bay in Middlesex County; however, modest declines were recorded in interior areas of Monmouth and Ocean Counties. Groundwater levels in both the Middle and Lower Potomac-RaritanMagothy aquifers were stable or rising within the regional cone of depression in Critical Area 2; beyond the critical area in southern New Jersey, however, water levels were slightly lower than in 2003.

Analyses of long-term water-level changes indicate that from 1978 to 2008 downward trends occurred at 20 wells (27 percent), upward trends at 27 wells (37 percent), and trends at 26 wells (36 percent) were insubstantial. Sustained, long-term declines were observed most often at wells within the Atlantic City 800-foot sand and at wells in the Piney Point aquifer in southern New Jersey, in which rates of decline were as great as 1.4 feet/year. Upward water-level trends were observed frequently at wells screened in the Englishtown aquifer system and the Wenonah-Mount Laurel aquifer in Critical Area 1 in east-central New Jersey, and in the PotomacRaritan-Magothy aquifer system in parts of Critical Area 1 and throughout most of Critical Area 2 in southern New Jersey. Annual rates of upward change were as great as 3.9 
and $5.6 \mathrm{ft} / \mathrm{yr}$ in the Englishtown aquifer system and WenonahMount Laurel aquifer, respectively. Among the units of the Potomac-Raritan-Magothy aquifer system, annual rates of recovery were greatest in the Lower aquifer.

From 1998 to 2008, downward water-level trends were observed at 22 wells ( 29 percent), upward trends were observed at 21 wells ( 27 percent), and insubstantial trends at 34 wells (44 percent). Downward trends were detected most often at wells open to the Piney Point aquifer and the Atlantic City 800-foot sand. Upward water-level trends were most frequent in wells open to the Englishtown aquifer system in Critical Area 1 and in wells within the Potomac-Raritan-Magothy aquifer system in southern New Jersey.

\section{Introduction}

The Coastal Plain aquifers of New Jersey provide an important source of water for more than 2 million people. Groundwater withdrawals from Coastal Plain aquifers have steadily increased from less than 50 million gallons per day (Mgal/d) prior to 1920 to more than $300 \mathrm{Mgal} / \mathrm{d}$ in the late 1980s and early 1990s (unpublished data on file at the U.S. Geological Survey (USGS), New Jersey Water Science Center). As a result, water levels in the confined aquifers have steadily declined, and regional cones of depression have formed. In addition to the loss of storage, declining water levels in these aquifers have caused reversals in natural hydraulic gradients that have, in some areas, induced the movement of brackish or saline water from estuaries, bays, and adjacent aquifers to freshwater aquifers.

Prior to 1978, groundwater levels were measured and cones of depression were mapped in response to local hydrologic issues. To provide water-supply managers, regulators, and scientists with a regional assessment of groundwater conditions in multiple aquifers, the USGS, in cooperation with the New Jersey Department of Environmental Protection (NJDEP), initiated a plan in 1978 to map the potentiometric surfaces of the major confined aquifers on a 5-year cyclical basis. Such assessments provide a broad view of the effects of groundwater development and are an essential component to managing and sustaining the region's water supply. In 1988, the plan of study was expanded to include selected water-level measurements in Delaware in order to better define cones of depression that propagated beneath the Delaware River and Bay. To date, potentiometric surfaces in 1978, 1983, 1988, 1993, 1998, and 2003 have been mapped.

In 1985, concern over the long-term decline in water levels in areas where groundwater was the primary or sole source of supply prompted the NJDEP to designate two water-supply Critical Areas in the New Jersey Coastal Plain. Critical Area 1 is in the east-central part of the State and Critical Area 2 is in the Camden County area of southern New Jersey. Each Critical Area is composed of a depleted zone and a threatened margin. The boundary of the depleted zone corresponds to the average -30-feet potentiometric contour in each of the regulated aquifers, which is based on the 1983 maps by Eckel and Walker (1986). A 3-mile-wide buffer, known as the threatened margin, surrounds the depleted zone of each aquifer and addresses the potential for saltwater intrusion as a result of this decline in water levels. Critical Area boundaries shown on maps in this report are composites that include the largest surface extents of both the depleted zone and the threatened margin of each of the affected aquifers.

Critical Area 1, designated in 1985, encompasses parts of Middlesex, Monmouth, and Ocean Counties (fig. 1). Regulated aquifers within Critical Area 1 apply to, in increasing order of depth, the Wenonah-Mount Laurel aquifer, the Englishtown aquifer system, and the Upper and Middle PotomacRaritan-Magothy aquifers (PRM). Mandatory reductions in groundwater withdrawals from production wells within the depleted zones of the Wenonah-Mount Laurel aquifer, the Englishtown aquifer system, and the Middle PRM aquifer were set at 50 percent relative to 1983 volumes, whereas those in the Upper PRM aquifer were set at 40 percent of 1983 volumes. Within the threatened margin, allocated withdrawals remained at 1983 volumes (New Jersey Administrative Code 7:19-8.4, 2005). Critical Area 1 restrictions were implemented in 1989, but because access to alternate water supplies was not initially available, compliance by most individual purveyors was deferred until 1991.

Prior to the recovery and subsequent stabilization of water levels during the early 1990s throughout Critical Area 1, water levels declined by as much as 135, 260, and 300 feet relative to predevelopment conditions in the Middle PRM aquifer, Wenonah-Mount Laurel aquifer, and Englishtown aquifer system, respectively. Upon completion of the Manasquan Reservoir in 1991, which can supply the region with approximately 30 million gallons per day (Mgal/d) of surface water (New Jersey Water Supply Authority, 2005), withdrawals from confined Coastal Plain aquifers in this area were reduced and replaced with surface-water withdrawals and, to a lesser extent, withdrawals from shallower, unconfined aquifers (Watt, 2000), initiating a reversal in the long-term decline in water levels. As of 2008, water levels have recovered from lows observed during $1983-88$ by as much as 67,150 , and $187 \mathrm{ft}$ in the Middle PRM aquifer, the Wenonah-Mount Laurel aquifer, and the Englishtown aquifer system, respectively.

In an effort to improve the management of groundwater resources of the PRM aquifer system in southern New Jersey, Critical Area 2 was designated in 1993. Groundwater availability issues within the region included widespread declining water levels and loss of storage associated with development of groundwater resources for public supply and the potential for movement of saline water from Gloucester County and downdip areas toward the Camden area cone of depression. The management area encompasses Camden, most of Burlington and Gloucester, and parts of Atlantic, Cumberland, Ocean, Monmouth, and Salem Counties (fig. 1), although regulations are most applicable to the first three counties. Restrictions on groundwater withdrawals apply only to the 
A

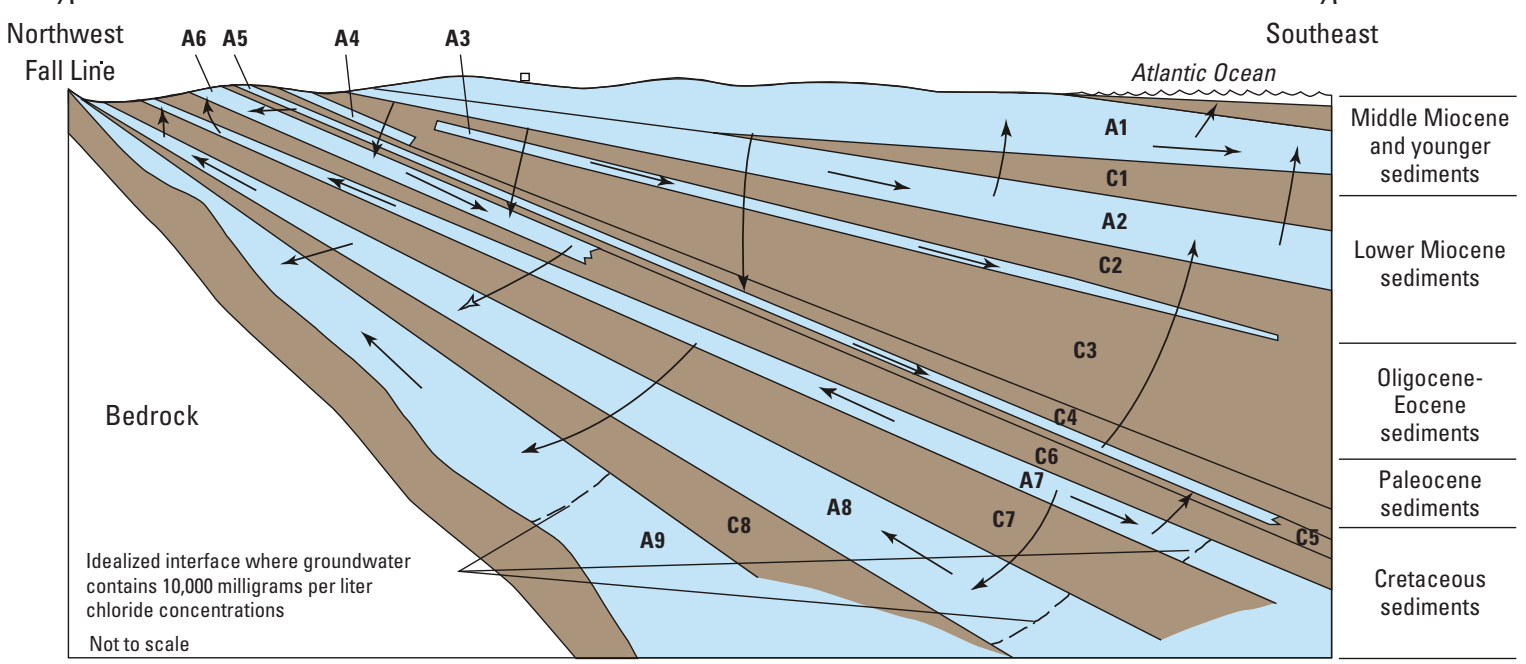

EXPLANATION

$\begin{array}{ll}\text { Aquifer } & \longrightarrow \begin{array}{c}\text { Generalized direction } \\ \text { of groundwater flow }\end{array} \\ \text { Confining unit } & \end{array}$

\section{Hydrogeologic unit}

A1 Upper unconfined Kirkwood-Cohansey aquifer

C1 Confining unit overlying the lower Kirkwood Formation aquifer (Atlantic City 800-foot sand); also contains the Rio Grande water-bearing zone

A2 Confining lower Kirkwood Formation aquifer (Atlantic City 800 -foot sand)

C2 Basal Kirkwood Formation confining unit; the upper part of the composite confining unit

A3 Confined Piney Point aquifer

C3 Composite confining unit

A4 Vincentown aquifer

C4 Navesink-Hornerstown confining unit

A5 Wenonah-Mount Laurel aquifer

C5 Marshalltown-Wenonah confining unit

A6 Englishtown aquifer system

C6 Merchantville-Woodbury confining unit

A7 Upper Potomac-Raritan-Magothy aquifer

C7 Confining unit between the Middle and Upper Potomac-Raritan-Magothy aquifers

A8 Middle Potomac-Raritan-Magothy aquifer

C8 Confining unit between the Lower and Middle Potomac-Raritan-Magothy aquifers

A9 Lower Potomac-Raritan-Magothy aquifer

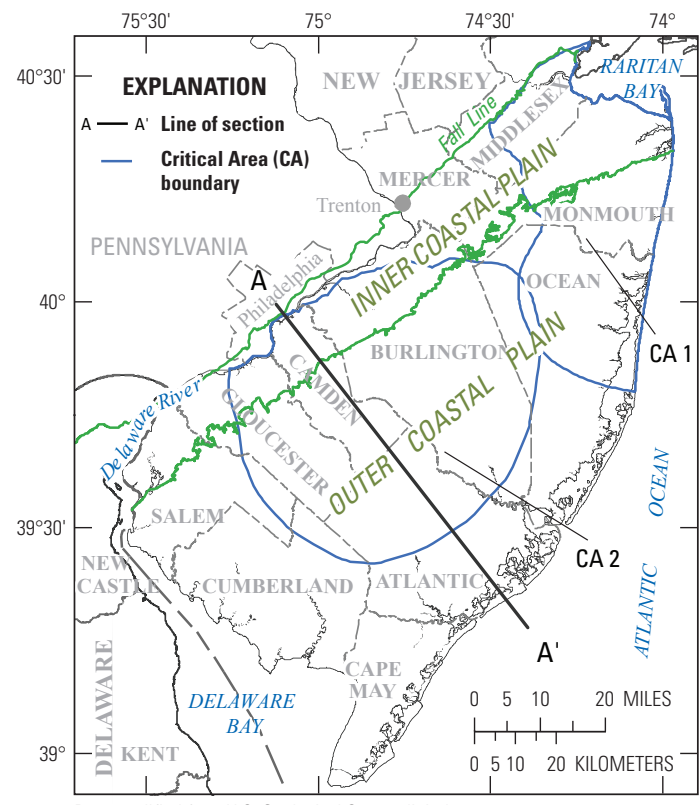

Base modified from U.S. Geological Survey digital

data, 1:24,000 Universal Transverse Mercator

Projection, Zone 18, NAD 83

Figure 1. Location of the study area and generalized representation of simulated prepumping flow in a hydrogeologic section through the Coastal Plain of southern New Jersey. 
aquifers of the PRM and were initiated in 1996. Groundwater withdrawals in the depleted zone were reduced by an average of 22 percent relative to 1983 volumes, whereas within the threatened margin, withdrawals were limited to the maximum annual volume between 1983 and 1991 (New Jersey Administrative Code 7:19-8.5, 2005). Development of shallower, non-restricted aquifers was encouraged and specific conservation measures introduced to curtail groundwater withdrawals within the region including the use of the Tri-County Pipeline, which began operation in 1996 and can provide more than $30 \mathrm{Mgal} / \mathrm{d}$ of water from the Delaware River to users within Burlington, Camden, and Gloucester Counties. In addition, parts of Burlington County were recognized as a Water Allocation Credit Receiving Area, whereby allocated withdrawals may be transferred locally to developing areas based on formulae set forth by the NJDEP (New Jersey Administrative Code, $7: 19-8.5,2005)$. Reductions in groundwater withdrawals coupled with the use of alternative surface-water sources have resulted in substantial rises in water levels in Critical Area 2, and as of 2008, water levels have recovered from lows observed during $1988-93$ by as much as 53,40 , and $50 \mathrm{ft}$ in the Upper, Middle, and Lower PRM aquifers, respectively.

\section{Purpose and Scope}

The scope and objectives of this report are to characterize 2008 groundwater conditions within selected confined aquifers of the New Jersey Coastal Plain and to evaluate groundwaterlevel changes in each during selected time periods using potentiometric-surface and water-level-change maps and simple trend statistics. Hydrographs that illustrate seasonal variations and the long-term effects of groundwater withdrawals are provided for 83 wells. Groundwater withdrawals from the 10 confined aquifers in New Jersey are compiled for 1978 to 2008 and presented in various maps, graphs, and tables throughout the report. Basic well-characteristic and waterlevel data are included in the appendixes. This report is the seventh in the series of reports that show the potentiometric surfaces for the major confined aquifers of the New Jersey Coastal Plain.

\section{Description of Study Area}

The study area encompasses the Coastal Plain Physiographic Province of New Jersey, eastern Pennsylvania, and parts of the Coastal Plain in Delaware. Although the study area extends offshore and beneath the continental shelf, the primary focus of the study was on the emerged parts of the Coastal Plain in the three States, an area of approximately 5,400 square miles $\left(\mathrm{mi}^{2}\right)$. The study area, shown in figure 1, is bounded on the west by the Fall Line and on the east by the Atlantic Ocean. This investigation focuses on the counties of Atlantic, Burlington, Camden, Cape May, Cumberland, Gloucester, Monmouth, Ocean, Salem, and parts of Mercer and Middlesex in New Jersey but includes limited parts of
Kent and New Castle Counties in Delaware and parts of Philadelphia County in Pennsylvania. Topography within the study area is relatively flat; altitudes range from $0 \mathrm{ft}$ along estuaries, bays, and the Atlantic coastline to nearly $400 \mathrm{ft}$ at the transition of the inner and outer Coastal Plain sub-provinces in western Monmouth County, New Jersey. For purposes of geographic comparison, the New Jersey counties of Mercer, Middlesex, Monmouth, and Ocean are referred to in this report as the northern counties within the Coastal Plain; the remaining counties within the Coastal Plain-Atlantic, Burlington, Camden, Cape May, Cumberland, Gloucester, and Salem - are referred to as the southern counties.

Groundwater has historically been the primary source of potable supply throughout much of the study area. The broad, flat stream valleys characteristic of the low-relief topography of the Coastal Plain generally are not practical for surface-water impoundments. A thick sequence of unconsolidated sands and gravels that underlie the study area, however, provide an abundant source of freshwater, enabling the development of many areas within the Coastal Plain for moderate to large populations. In recent years, declining water levels and instances of saltwater intrusion initiated a shift toward alternate sources of supply. From 1985 to 2008 surface water as a percentage of the total public supply among Coastal Plain populations increased from 11 to nearly 25 percent. As a result, declining groundwater levels in threatened aquifers began, and continue, to recover.

\section{Hydrogeologic Framework}

The hydrogeologic framework used in this report was developed for the New Jersey Coastal Plain Regional Aquifer System Analysis (RASA) study by Zapecza (1989) and consists of a southeastward dipping and thickening wedge of unconsolidated deposits of sand, silt, and clay of Cretaceous to Tertiary age underlain by basement rocks and overlain by a veneer of locally occurring Quaternary sediments. Coastal Plain sediments were deposited in various shelf, marginal marine, near shore or coastal beach, and deltaic environments, the extent of which fluctuated in response to relative changes in sea level. Units composed of distinctly less permeable sediments (predominantly clays and fine-grained silts) form the confining units, and coarser, more permeable sand and gravel units, which readily produce water, form the aquifers. These deposits are less than $50 \mathrm{ft}$ thick along the western limit of the Coastal Plain (Fall Line) and thicken to more than 6,500 ft in southern Cape May County. Coastal Plain sediments of Cretaceous and Tertiary age generally strike northeast-southwest and dip 10 to 60 feet per mile $(\mathrm{ft} / \mathrm{mi})$ to the southeast (Zapecza, 1989); overlying Quaternary deposits are flat. Many of these units crop out near the Fall Line parallel to strike, transitioning into unconfined aquifers; others such as the Piney Point aquifer are confined throughout the study area. The aquifers and confining units discussed in this report range in age from Lower Cretaceous to Miocene (table 1). A brief description of each aquifer is included in sections devoted to 
Table 1. Geologic and hydrogeologic units of the New Jersey Coastal Plain.

[Aquifers in bold print are those discussed in report. Modified from Zapecza, 1989, and Sugarman, 2001]

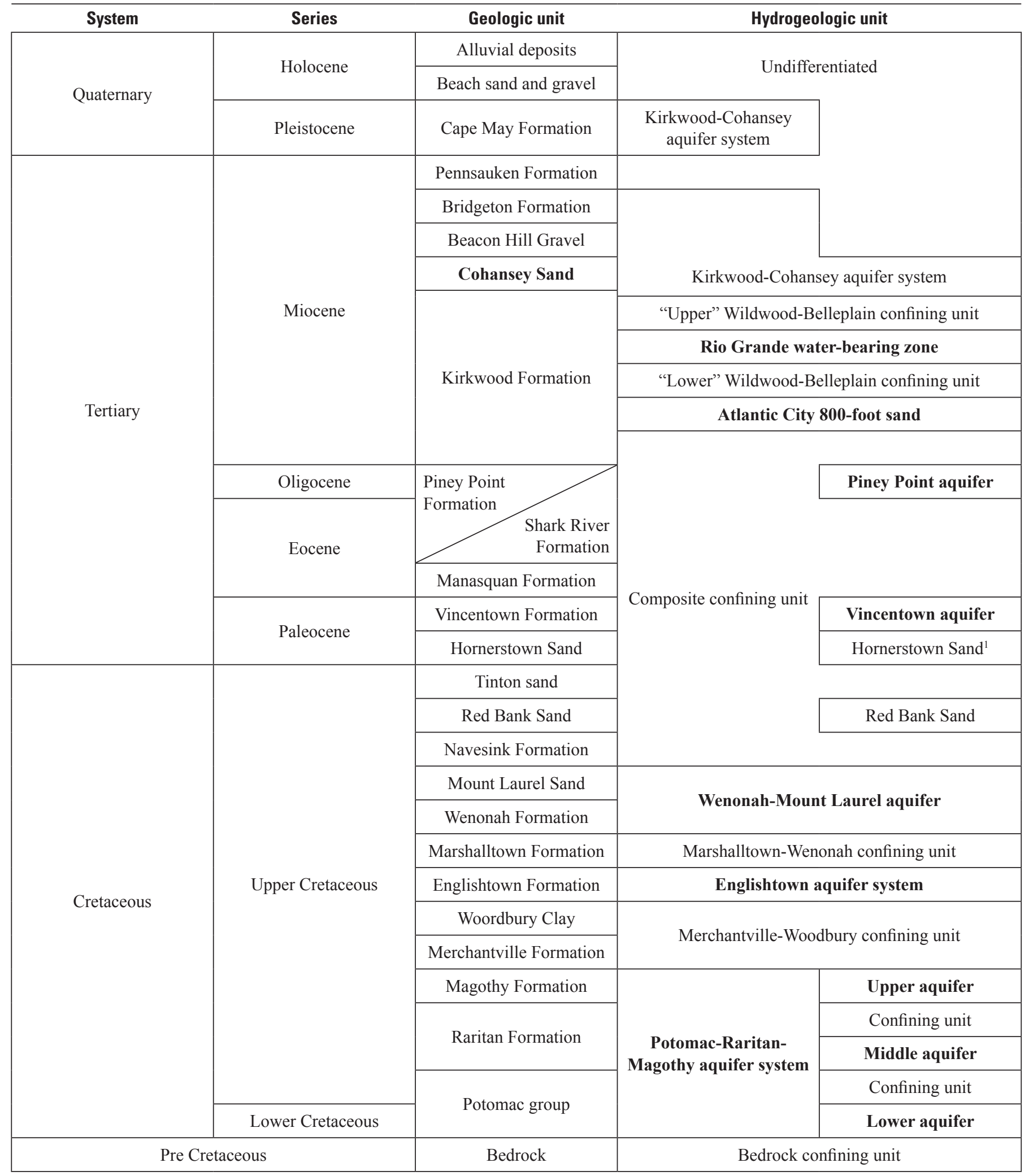

${ }^{1}$ Not designated as a formal aquifer by Zapecza (1989). 
individual aquifers; for a more detailed discussion, Zapecza (1989) and Sugarman and others (2005) describe the hydrogeology of New Jersey and Vroblesky and Fleck (1991), the hydrogeology of Delaware.

\section{Well Numbering System}

In this report, wells are listed by their USGS identification numbers. For wells located in New Jersey and Pennsylvania, the well-numbering system consists of a county code number followed by a sequence number for wells within that county. For example, well number $15-123$ is the 123 rd well inventoried in Gloucester County. In Maryland, the numbering system consists of a county code, followed by the 5-minute quadrangle code and a number indicating the order in which the well was inventoried in that quadrangle. For example, well CO Bd 53 is located in Caroline County as indicated by "CO," is in the 5-minute quadrangle "Bd," and is the 53rd well mapped in that quadrangle. County codes for New Jersey, Pennsylvania, and Maryland are listed in table 2. Well identifiers in Delaware are assigned by the Delaware Geological Survey and are numbered on the basis of a coordinate system using 5-minute quadrangles of latitude and longitude.

Table 2. County prefix codes used in well-numbering systems in New Jersey, Pennsylvania, and Maryland.

\begin{tabular}{lcll}
\hline County name & Code & County name & Code \\
\hline \multicolumn{5}{c}{ New Jersey } \\
\hline Atlantic & 01 & Mercer & 21 \\
Burlington & 05 & Middlesex & 23 \\
Camden & 07 & Monmouth & 25 \\
Cape May & 09 & Ocean & 29 \\
Cumberland & 11 & Salem & 33 \\
Gloucester & 15 & & \\
\hline \multicolumn{5}{c}{ Pennsylvania } \\
\hline Philadelphia & P & & \\
\hline \multicolumn{5}{c}{ Maryland } \\
\hline Cecil & CE & & \\
Caroline & CO & & \\
\hline
\end{tabular}

\section{Previous Investigations}

Various regional studies describe groundwater-level data, potentiometric surfaces, and groundwater flow in the New Jersey Coastal Plain. Previous potentiometric surface maps in this series present groundwater levels in the study area at 5-year intervals from 1978 through 2003: 1978, Walker (1983); 1983, Eckel and Walker (1986); 1988, Rosman and others (1996); 1993 and 1998, Lacombe and Rosman (1997, 2001); and 2003, DePaul and others (2009). The confined-aquifer waterlevel map series is supplemented by water-table maps for the unconfined aquifers within the following basins of the New Jersey Coastal Plain: Mullica River Basin (Johnson and Watt, 1996); Salem River, Raccoon, Oldmans, Alloway, and Stow Creek Basins (Johnson and Charles, 1997); Upper Maurice River Basin (Lacombe and Rosman, 1995); Great Egg Harbor River Basin (Watt and Johnson, 1992); Rancocas, Crosswicks, Assunpink, Blacks, and Crafts Creek Basins (Watt and others, 2003); and the Toms River, Metedeconk River, and Kettle Creek Basins (Watt and others, 1994).

Countywide water-resources studies were conducted by Barksdale and others (1943), Jablonski (1968), and Anderson and Appel (1969) for Middlesex, Monmouth, and Ocean Counties, respectively. Rush (1968), Farlekas and others (1983), Hardt and Hilton (1969), Rosenau and others (1969), Gill (1962), and Lacombe and Carleton (2002) completed water-resource studies for the southern counties of Burlington, Camden, Gloucester, Salem, and Cape May, respectively.

Simulations of groundwater flow from a regional perspective within the New Jersey Coastal Plain are described in Martin (1998), Pope and Gordon (1999), and Voronin (2004). Pucci and others (1994), Navoy and Carleton (1995), and McAuley and others (2001) did detailed studies, including groundwater-flow models of Critical Area 1, Critical Area 2, and the Atlantic City area, respectively. In Critical Area 2, Navoy and others (2005) simulated the vulnerability of publicsupply wells open to the Potomac-Raritan-Magothy aquifer system to saltwater intrusion, and Navoy (1994) simulated the effects of projected withdrawals on water levels in the Wenonah-Mount Laurel aquifer. Groundwater-level recovery in Critical Area 1 and Critical Area 2 is discussed in Spitz and others (2008) and Spitz and DePaul (2008).

Simulations of the effects of allocated and projected withdrawals on water levels in the Potomac-Raritan-Magothy aquifer system in Gloucester and Salem Counties are reported by Charles and others (2011). Voronin and others (1996), Spitz (1998), and Lacombe and others (2009) simulated groundwater flow in confined aquifers in Cape May County. Pope (2006) simulated effects of increased withdrawals on water levels in the Atlantic City 800-foot sand.

\section{Data Collection and Analysis}

Static groundwater-level altitudes were measured in 926 wells in New Jersey and Pennsylvania by USGS personnel. Water levels were measured in additional wells in Delaware by personnel of the Delaware Department of Natural Resources and Environmental Control (DNREC). Water levels used in this study, most of which were measured during late October to mid-December 2008, are assumed to represent the 2008 average annual water level in that aquifer at that location within the study area; in some cases water levels were recovering from high summer withdrawal rates and had not yet reached the mean annual water level, but the difference from mean annual, where it exists, is generally small. Water levels 
measured at about the same time of year once every 5 years can be compared to each other to reveal long-term trends whether or not they are exactly the mean annual water levels for the respective years.

Water levels were measured at observation wells and production wells used for industrial, commercial, irrigation, domestic, and public supply; wells used for measurement were generally chosen on the basis of areal distribution within each aquifer. Measurements made at observation wells constitute about one-third of the dataset, and in order to maximize the geographic distribution and to capture low water levels associated with withdrawals, the network was augmented with production wells. Measurements were made using steel or electric tapes graduated to hundredths of a foot, which are the most accurate devices, or using an airline, which is less accurate. The airline method was used in limited instances and only at wells that were inaccessible for measuring by either electric or steel tape. Pumps in high-capacity supply wells were turned off for a minimum of 1 hour before measurement of the water level in the well. In addition, nearby pumping was controlled at the time of measurement; pumps in all other high-capacity production wells screened in the same aquifer within $0.25 \mathrm{mi}$ of the measured well were idle for at least 1 hour prior to measurement of the water level. In accordance with USGS methods for the collection of water-level data, measurements were made in each well until two consecutive measurements within $0.05 \mathrm{ft}$ were obtained at least 5 minutes apart. The resulting water-level measurement was considered representative of static or near-static conditions. Importantly, "static" in this report is not intended to mean unaffected by withdrawals but rather representative of water levels in the area, not of those influenced by the very local effects of individual withdrawals. Water-level data are presented in appendixes 1 through 9.

Groundwater in three observation wells measured in this study had chloride concentrations in excess of 5,000 milligrams per liter $(\mathrm{mg} / \mathrm{L})$. Water levels in these wells were converted from a measured saltwater hydraulic head to a calculated freshwater head. The conversion equation follows a modification of the Ghyben-Herzberg relation (Todd, 1980) to determine the equivalent length of freshwater in a well filled with saltwater:

$$
l_{f}=\left(p_{s} / p_{f}\right) l_{s}
$$

where

$$
\begin{aligned}
& l_{f} \quad \begin{array}{l}
\text { is length of the freshwater column in the well } \\
\text { casing, }
\end{array} \\
& p_{s} \quad \text { is the density of saltwater, } \\
& p_{f} \quad \text { is the density of freshwater, and } \\
& l_{\mathrm{s}} \quad \text { is the length of saltwater column in the well } \\
& \quad \text { casing. }
\end{aligned}
$$

The density of freshwater is 1.00 gram per cubic centimeter $\left(\mathrm{g} / \mathrm{cm}^{3}\right)$, and the density of water increases with increasing solute concentrations. Adjusted water levels were used to contour the potentiometric surfaces; both the measured water levels and their freshwater equivalents are presented in the appendixes of the report.

The water level in a well represents the hydraulic head in the part of the aquifer to which the well is open. Hydraulic heads at each well were calculated by subtracting the water level, in feet below land surface, from the land-surface altitude, in feet above the National Geodetic Vertical Datum of 1929 (NGVD 29). In confined aquifers, this level typically stands above the top of the aquifer as a result of increases in pressure with depth and the presence of overlying, relatively impermeable strata. Maps depicting the areal distribution of hydraulic head within each aquifer then were constructed; lines of equal hydraulic head are represented on these maps by potentiometric-surface contours. From these maps groundwater flow in each aquifer can be inferred, as general flow directions are assumed to be perpendicular to the potentiometric-surface contours and in the direction of decreasing head. Although most of the data used in this study are composed of measurements made in the confined parts of the aquifers, in some cases, measurements made in the unconfined parts are included in order to guide placement of potentiometric contours at the aquifer outcrops.

On the plate maps accompanying this report, the symbol for an observation well applies not only to the original use of the well, but to wells that had not been pumped during the 7 days prior to measurement. Prior to 1998 , reports in this series applied the term "observation well" to a well that had not been pumped within the 24 hours prior to measurement. Because of wide variations in the hydraulic characteristics among the aquifers within the study area, the residual effects of pumping stresses also differ greatly, and therefore, this "idle period" for observation-well classification was lengthened to 7 days.

Groundwater-level-change maps for selected aquifers were constructed by comparing the potentiometric surfaces and groundwater-level measurements from 2003 and 2008. Water-level-change values were calculated as the difference between the 2003 and 2008 groundwater-level altitudes, except where continuous or semi-continuous hydrograph data were available; in those cases, a calculated slope was used to determine water-level change. In limited cases, water levels measured during 2008 that were not measured during prior studies were compared to an estimated water level derived from the earlier potentiometric surface map at that location. In addition, where measurements were sparse or absent, particularly in downdip areas of some units, points representing the differences in the potentiometric surface at the intersections of two contours were used to provide additional spatial coverage. The water-level-change values were plotted on digital base maps and initially contoured by using geographic information systems (GIS) software to provide an unbiased interpolation of the data. The contours were then manually adjusted to reflect the understanding of the groundwater system. Raster datasets were constructed from the resulting "difference" contours and points in order to provide estimates of groundwater-level change in areas lacking measurements. While these maps 
provide a spatial perspective in assessing water-level change throughout individual aquifers over a given time period, interpretations based on these maps are best viewed with some caution. In most cases, the density of data throughout a given aquifer may be insufficient to support the interpretation and use on a local scale. Additionally, many of the data points used in the construction of these maps are based on two measurements that represent a long-term net change in water levels; in the absence of continuous long-term water-level data, the direction and rate of change during intervening time periods may fluctuate and not be known, and cannot be resolved through use of intermittent data points. Further, uncertainty may be introduced by the relative positions of the compared water-level measurements on the annual hydrograph. Finally, equivalent gradational scales were used on all maps to maintain consistency; a change of -5 to $+5 \mathrm{ft}$ is classified as "no substantial change," and lesser water-level changes are not shown.

Water-level data from wells with at least 15 years of record were used to produce the hydrographs shown in various figures throughout this report, with the exception of those for the Rio Grande water-bearing zone, where water levels were collected intermittently. In many cases, hydrographs show periods of record beyond 15 years, and many span the 30 -year period from 1978 to 2008 . The water-level data used to construct the hydrographs are a combination of continuous measurements and manual measurements collected on a seasonal basis. These data illustrate seasonal variations in water levels; the long-term effects of artificial stresses, such as pumping; and in some cases, the development and recovery of depressions in the potentiometric surface. Where temporal density and continuity of long-term water-level measurements were sufficient, trends were statistically analyzed by using the Mann-Kendall trend test, a commonly used method to assess monotonic change in time-series data (Mann, 1945; Helsel and Hirsch, 2002). The Mann-Kendall method is a nonparametric trend test that determines whether a statistically significant positive or negative change in a constituent (in this case, depth to water) has occurred over the period of interest. The method, however, does not imply whether change is linear nor does it determine the magnitude of change. Calculation of Sen's slope for each of the test periods was used to quantify the magnitude of annual water-level change (Sen, 1968; Gilbert, 1987). Because water levels may vary throughout the year as a result of seasonal demand and withdrawal patterns, a modified test that accounts for seasonality in the data, determined from Wilcoxon scores, was used (Hirsch and Slack, 1984; Winkler, 2004). For the purposes of this study, an upward or downward change over a given period of time was considered statistically significant if the Mann-Kendall trend test had a 95-percent confidence level ( $p$ value of 0.05 ) and if the average yearly change, as indicated by the slope of the line, was greater than or equal to 0.2 feet per year ( $\mathrm{ft} / \mathrm{yr}$ ). If the slope was less than $0.2 \mathrm{ft} / \mathrm{yr}$, the indicated yearly change was considered insubstantial. Analyses focused on the 5-year period from 2003 to 2008, the decadal period of 1998 through 2008, and the
30 -year period from 1978 to 2008 . The 30 -year period coincides with the duration of the individual water-level synoptic studies in this series and is used to illustrate long-term trends not dominated by short-term variations in climate or withdrawal patterns. Because trends observed in many of the wells were not always unidirectional from the beginning to the end of a cycle, trends in different directions may cancel each other out, leading to the conclusion of an "insignificant trend" for a given time period.

In addition to trend tests on long-term water-level data, hypothesis tests were performed on the medians of paired differences between the 2003 and 2008 and the decadal (1998-2008) measurements using the non-parametric Wilcoxon signed-rank test (Wilcoxon, 1945; Helsel and Hirsch, 2002). The null hypothesis for each test was that the median difference between paired measurements is equal to zero or that no statistical difference exists between compared measurements. Because the ranks of differences rather than the actual values are used, the magnitude of the differences does not affect the outcome of the test. Differences were considered significant if a $p$-value of less than or equal to $(\leq) 0.05$ (95-percent confidence level) was attained, that is, a 1 in 20 chance of obtaining this correlation by random occurrence. As the $p$-value decreases, evidence for rejecting the null hypothesis increases. Tests were performed on data grouped according to aquifer, aquifer and county, and aquifer and selected management-area boundaries.

The location of the 10,000-mg/L line of equal chloride concentration (approximately half that of seawater) was simulated for selected aquifers in the New Jersey Coastal Plain by use of the USGS SHARP model (Pope and Gordon, 1999). The locations of these lines (hereafter referred to as isochlor) on selected plates represent the toe of the saltwater interface, that is, the intersection of the interface with the bottom of the aquifer, generally its farthest landward or updip position. Because of disequilibrium of the flow system with present day sea level, the position of the interface is more closely related to predevelopment rather than current groundwater conditions, and despite future scenarios of increasing withdrawals and deepening cones of depression, numerical simulations indicate little to no movement (Pope and Gordon, 1999). As such, these boundaries likely have not moved substantially in response to changing groundwater conditions observed throughout past study cycles and, therefore, have not been updated. The locations of the $10,000-\mathrm{mg} / \mathrm{L}$ isochlors for the aquifers of the Delaware Coastal Plain are based on maps by Vroblesky and Fleck (1991). The location of the 250-mg/L isochlor, which designates the limit of potable water in each aquifer as defined by NJDEP secondary drinking-water standards (New Jersey Administrative Code, 2004), is based on published maps that are cited for each aquifer. If no map was available to show the location of the $250-\mathrm{mg} / \mathrm{L}$ isochlor in a particular aquifer, the line was determined from chloride data stored in the USGS National Water Information System database (NWIS) and the NJDEP quarterly monitoring database. Modifications from previously published maps in this report series were made to 
these $250-\mathrm{mg} / \mathrm{L}$ isochlors as current (2003-8) water-quality data warranted.

Groundwater-withdrawal data for central and southern New Jersey were tabulated and mapped in order to assess volumes of water pumped from each of the aquifers. Data were compiled from permitted data only, that is, wells in which daily withdrawals meet or exceed 100,000 gallons for a period of more than 30 days in a consecutive 365-day period. Such wells include those used for public-supply, large-scale agriculture (irrigation), and commercial or industrial purposes. No attempt was made to estimate withdrawals from numerous smaller-capacity production wells, such as those used for domestic supply, which is a limitation of the analysis. Withdrawal data cited in this report were obtained from data reported to the New Jersey Department of Environmental Protection and were quality reviewed and incorporated into the water-use database of the USGS New Jersey Water Science Center. Additional withdrawal data from the late 1970s were obtained from Zapecza and others (1987).

\section{Cohansey Aquifer}

The Cohansey aquifer in Cape May County is the youngest and uppermost confined aquifer considered in this study. The aquifer is composed of gravel and coarse- to fine-grained sands and includes the lower part of the Cohansey Formation and the sand-rich uppermost section of the Kirkwood Formation (Zapecza, 1989). Throughout Cape May County, Pleistocene deposits of sand and clay overlie the Cohansey aquifer, providing effective confinement from surficial recharge. In northern Cape May County, the Cohansey aquifer underlies the Holly Beach water-bearing zone and is confined by one or more discontinuous clay deposits, whereas in the southern part of the county two intervening widespread and uniform confining units and the estuarine sand aquifer overlie the Cohansey aquifer. The aquifer in Cape May County ranges in thickness from $50 \mathrm{ft}$ near Ocean City to more than $150 \mathrm{ft}$ near the southern tip of the peninsula (Lacombe and Carleton, 2002). The limit of confinement is in northern Cape May County, approximately bounded by the Tuckahoe River and a northeast-trending line from the mouth of the Maurice River at Delaware Bay to the intersection of Cape May, Cumberland, and Atlantic Counties.

The Cohansey aquifer contains freshwater throughout most of the extent underlying mainland Cape May County; however, saline water is present in the aquifer beneath the extreme southern part of the peninsula, beneath the back bays and barrier islands north of Wildwood, and beneath near-shore and offshore areas of the Atlantic Ocean and the Delaware Bay (pl. 1). Additionally, saltwater has migrated into freshwater parts of the aquifer along the western coast of the peninsula, west of the village of Rio Grande. The saltwater-freshwater interface (hereafter referred to as saltwater front), as indicated by $250-\mathrm{mg} / \mathrm{L}$ isochlor, was originally mapped by Gill (1962) and updated by Lacombe and Rosman (2001), Lacombe and Carleton (2002), and DePaul and others (2009). The estimated position of the saltwater front is mapped farther inland than in previous studies, near Villas, Cape May County, reflecting the rapidly rising chloride concentrations observed in well 9-187, which increased from $190 \mathrm{mg} / \mathrm{L}$ in 1996 to $805 \mathrm{mg} / \mathrm{L}$ in 2005 . A groundwater sample collected in early 2010 yielded a chloride concentration of $1,150 \mathrm{mg} / \mathrm{L}$, confirming the $70-\mathrm{mg} / \mathrm{L}$ annual rate of increase. The chemistry of the water from this well is consistent with seawater intrusion into coastal fresh groundwaters. The composition of the groundwater is that of a calcium-chloride type, indicative of base-exchange reactions with aquifer materials, whereby the uptake of sodium into the solid phase (primarily on clay minerals and organic matter within the aquifer matrix) is enhanced, replacing calcium ions that are subsequently released to solution (Vengosh, 2003). This results in low molar ratios of sodium to chloride relative to seawater $(<0.86)$, as well as low ratios of both sulfate and boron to chloride. Lacombe and others (2009) indicate that withdrawals at the Rio Grande well field are a possible cause of intrusion in this area. Similarly, chloride concentrations in well 9-89, along the western coast of the peninsula and 2.8 miles to the north of well 9-187, have increased linearly since 2003; sodium to chloride molar ratios in groundwater from this well also have decreased during the same time period, indicating a mix of seawater with fresher groundwaters. Immediately to the south of Villas, however, the groundwater remains fresh along the western coast of the peninsula where chloride concentrations are typically less than $15 \mathrm{mg} / \mathrm{L}$, and no sustained increases have been observed during the past decade. Approximately $2 \mathrm{mi}$ to the east of well 9-187, at the Rio Grande well field (fig. 2), chloride concentrations in a production well have increased from about $15 \mathrm{mg} / \mathrm{L}$ to as high as $83 \mathrm{mg} / \mathrm{L}$ during 1998-2009. Although concentrations in this well are typically around $50 \mathrm{mg} / \mathrm{L}$, decreasing sodium to chloride ratios along with increasing chloride concentrations indicate the possible movement of water from the Delaware Bay.

\section{Water withdrawals}

The distribution of withdrawals from the Cohansey aquifer in Cape May County is shown in figure 2. Groundwater withdrawals are most common in the southern part of the peninsula in upland areas of Middle and Lower Townships, although smaller-capacity production wells are located throughout the central and northern parts of the county. During 2008, approximately $4 \mathrm{Mgal} / \mathrm{d}$ (75 percent of total withdrawals) were withdrawn for public supply, lesser amounts were withdrawn for industrial, irrigation, and other purposes. In 2008, the Wildwood Water Utility (WWU), the largest user of groundwater from the Cohansey aquifer, withdrew an average of $2.0 \mathrm{Mgal} / \mathrm{d}$. Most of the withdrawals were concentrated at the well field at Rio Grande and accounted for 50 percent of public-supply withdrawals from the aquifer in 2008. The second largest user of the Cohansey aquifer, Lower Township 


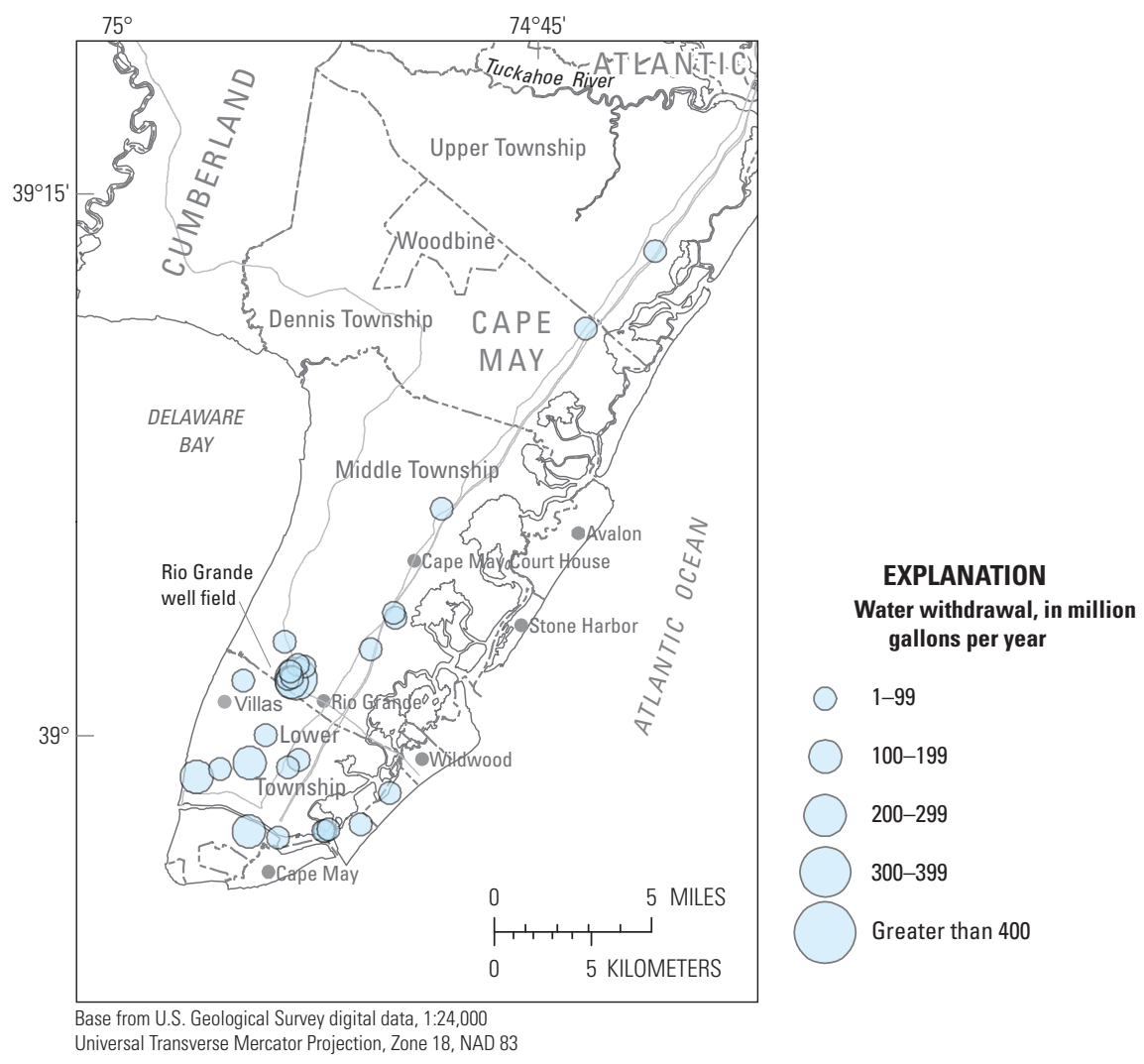

Figure 2. Location and volume of groundwater withdrawals from the confined Cohansey aquifer, southern Cape May County, New Jersey Coastal Plain, 2008.

Municipal Utilities Authority (LTMUA), accounted for an additional $1.1 \mathrm{Mgal} / \mathrm{d}$.

From 1978 to 2008, estimated withdrawals from the Cohansey aquifer ranged from 3.8 to $6.9 \mathrm{Mgal} / \mathrm{d}$. By 1982, withdrawals were at their peak and remained greater than $6 \mathrm{Mgal} / \mathrm{d}$ throughout the 1980s (fig. 3). During 1991-92 withdrawals decreased by 14 percent, and throughout the 1990s, average withdrawal rates were about $5.5 \mathrm{Mgal} / \mathrm{d}$. Following a brief increase from 1996 to 1998, withdrawals decreased with the introduction of Cape May City Water Department (CMCWD) wells tapping the Atlantic City 800-foot sand and supplying water to the desalination plant completed in 1998. From 1998 to 1999, withdrawals from the Cohansey aquifer decreased by 24 percent, the largest such reduction from any given year to the next. Withdrawal rates increased during $2000-1$, but from 2003 to 2008 withdrawals were further reduced by an additional 20 percent. Withdrawals of 3.8 Mgal/d in 2008 were the lowest since this series of studies commenced in 1978 (fig. 3; table 3).

Withdrawals by the two major utilities remained relatively constant from the early the 1980s to 2006; however, farther to the south substantial reductions occurred in Cape May City, coinciding with the use of production wells open to the Atlantic City 800 -foot sand. LTMUA slightly reduced withdrawals during 2006-7; however, they returned to antecedent withdrawal rates in 2008. From 2007 to 2008, WWU reduced withdrawals from the Cohansey aquifer at the Rio Grande well field by nearly $1 \mathrm{Mgal} / \mathrm{d}$ and replaced those by using withdrawals from deeper, less vulnerable aquifers. 


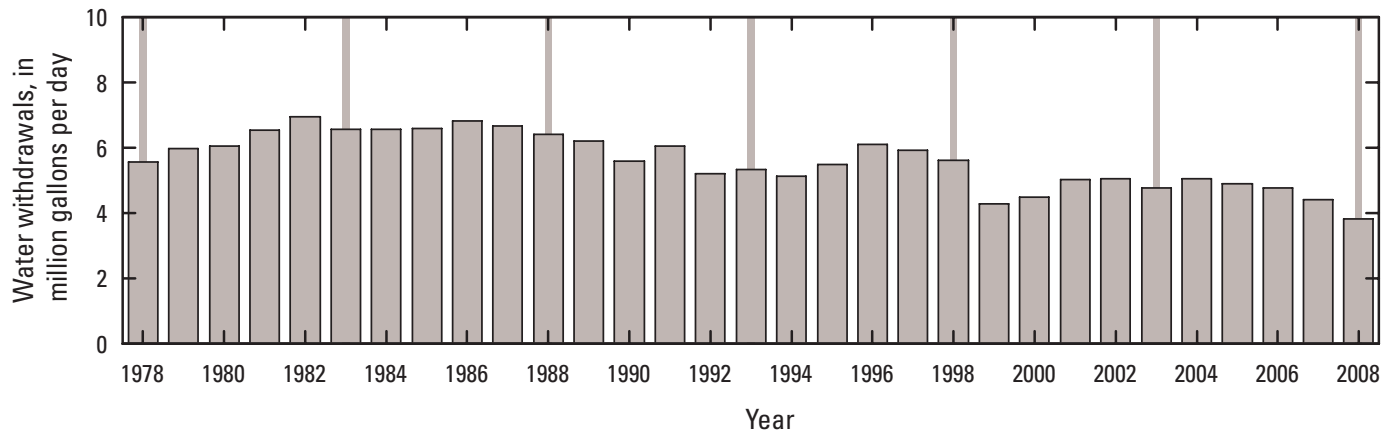

Figure 3. Estimated groundwater withdrawals from the confined Cohansey aquifer in Cape May County, New Jersey Coastal Plain, 1978-2008. (Thin vertical bars denote 5-yr data collection periods)

Table 3. Groundwater withdrawals by county and aquifer from selected confined aquifers of the New Jersey Coastal Plain, 2008.

[Withdrawals are in million gallons per day; only permitted and reported values included; <, less than; --, not applicable]

\begin{tabular}{|c|c|c|c|c|c|c|c|c|c|c|}
\hline \multirow[b]{2}{*}{ County } & \multicolumn{10}{|c|}{ Aquifer } \\
\hline & Cohansey ${ }^{1}$ & $\begin{array}{c}\text { Rio Grande } \\
\text { water- } \\
\text { bearing } \\
\text { zone }\end{array}$ & $\begin{array}{l}\text { Atlantic City } \\
800-\text { foot } \\
\text { sand }\end{array}$ & $\begin{array}{l}\text { Piney } \\
\text { Point }\end{array}$ & $\begin{array}{c}\text { Vincen- } \\
\text { town }\end{array}$ & $\begin{array}{l}\text { Wenonah- } \\
\text { Mount } \\
\text { Laurel }\end{array}$ & $\begin{array}{l}\text { English- } \\
\text { town } \\
\text { aquifer } \\
\text { system }\end{array}$ & $\begin{array}{c}\text { Upper } \\
\text { Potomac- } \\
\text { Raritan- } \\
\text { Magothy }\end{array}$ & $\begin{array}{l}\text { Middle } \\
\text { Potomac- } \\
\text { Raritan- } \\
\text { Magothy }\end{array}$ & $\begin{array}{l}\text { Lower } \\
\text { Potomac- } \\
\text { Raritan- } \\
\text { Magothy }\end{array}$ \\
\hline Atlantic & -- & -- & 11.8 & 0.6 & -- & -- & -- & -- & -- & -- \\
\hline Burlington & -- & -- & -- & 0.03 & $<0.01$ & 2.8 & 0.9 & 4.5 & 18.0 & 9.5 \\
\hline Cape May & 3.8 & 0.3 & 8.7 & -- & -- & -- & -- & -- & -- & -- \\
\hline Cumberland & -- & -- & -- & 0.5 & -- & -- & -- & 0.1 & -- & -- \\
\hline Gloucester & -- & -- & -- & -- & 0.1 & 1.4 & 0.04 & 8.7 & 6.0 & 2.8 \\
\hline Mercer & -- & -- & -- & -- & -- & -- & -- & 0.8 & 9.0 & -- \\
\hline Middlesex & -- & -- & -- & -- & -- & -- & -- & 15.8 & 8.4 & -- \\
\hline Salem & -- & -- & -- & -- & 0.03 & 1.2 & -- & 1.5 & 2.7 & 0.6 \\
\hline Total & 3.8 & 0.6 & 26.8 & 5.8 & 1.1 & 8.2 & 7.2 & 55.1 & 64.9 & 37.2 \\
\hline
\end{tabular}

${ }^{1}$ Cape May County only. 


\section{Water levels}

The potentiometric surface map for fall and early winter 2008 for the confined Cohansey aquifer is shown on plate 1 (fig. 1-1); supporting water-level data used to construct this map are presented in appendix 1-1. Because water-level altitudes in the northern part of Cape May County did not change appreciably since pumping began, the potentiometric surface of the aquifer underlying only the southern half of the Cape May peninsula was mapped. The configuration of the groundwater surface shows a broad cone of depression centered beneath major withdrawal locations in the southern part of the peninsula, encompassing all of Lower Township, Cape May, and West Cape May, as well as large parts of Middle Township and Wildwood Crest. The highest measured water-level altitudes in the confined Cohansey aquifer occurred in central and western Middle Townships and in areas to the north, ranging from about 4 to $6 \mathrm{ft}$. The lowest groundwater-level altitudes occurred in central and southern Lower Township in the vicinity of the LTMUA and CMCWD well fields, ranging from -9 to $-17 \mathrm{ft}$. In comparison, withdrawals from the WWU Rio Grande well field to the north are substantially greater than those from the LTMUA and CMCWD Cohansey aquifer wells (82 percent), yet heads are slightly higher. Lower observed groundwater levels to the south and west are consistent with a decrease in transmissivity toward the southwestern part of the peninsula and greater recharge in Middle Township and to the north. The groundwater surface within the study area slopes concentrically inward toward potentiometric lows in central and southern Lower Township, and flow is radially inward from the north and south, as well as from the Atlantic Ocean and Delaware Bay coastlines. The configuration of the potentiometric surface is similar to that of 2003; however, the area encompassed by the -10 -ft contour has contracted slightly from its previous extent as a result of reductions in Cohansey aquifer withdrawals at the WWU Rio Grande well field.

Vertical head differences were calculated as the differences in groundwater altitude between each aquifer and adjacent hydrogeologic units. These head differences are an indication of the direction and magnitude of hydraulic gradients that affect the vertical component of flow and provide insight into the potential for inter-aquifer flow. Calculation of such differences is predicated on the collection of accurate head data from multiple aquifers at individual wells or at wells in close proximity to one another. However, data of this type are limited throughout the study area, and estimated groundwater altitudes were compared to those in adjacent units above and below each aquifer to supplement the analysis. Because the Cohansey aquifer is the uppermost aquifer in this study and a recent potentiometric surface has not been constructed for the overlying estuarine sand aquifer, comparison could be made only with the underlying unit, the Rio Grande waterbearing zone. Throughout the study area, water levels within the Cohansey aquifer are greater than those in the Rio Grande water-bearing zone. The potential for downward flow from the aquifer is strongest throughout the central part of Cape
May County, where vertical head differences are typically 20 to $25 \mathrm{ft}$, and probably weakest toward the southern tip of the peninsula.

Small to moderate net water-level changes were measured in most wells during 2008; from a regional perspective, however, water levels generally remained about the same relative to those observed in 2003. Results of the Wilcoxon signed-rank test indicate that no statistically significant difference is present among 38 matched data pairs measured in 2003 and 2008. Water levels increased in 21 wells (55 percent), were unchanged in 4 wells (11 percent), and decreased in 13 wells (34 percent). Water-level changes range from declines of 2 to $3 \mathrm{ft}$ at the northeastern and southwestern edges of the cone of depression to rises of 2 to $9 \mathrm{ft}$ in central and northern Lower Township (fig. 4). For the 10-year period 1998-2008, results indicate that there was a statistically significant rise in water levels.

Long-term water-level trends in the Cohansey aquifer were evaluated both graphically and statistically. The magnitude of groundwater-level changes in the Cohansey aquifer, as well as the other confined aquifers throughout the Coastal Plain, depends upon changes in storage within the aquifer, which is a function of its hydraulic properties, and the distribution and changes in patterns of recharge and discharge (including withdrawals). Climatic variations affect water levels in confined aquifers only indirectly and are not considered in this report.

Hydrographs of four wells located within and at the edges of the cone of depression in southern Cape May County are shown in figure 5. Each hydrograph depicts water-level altitudes at or below $0 \mathrm{ft}$ since the initial study in 1978 . The hydrographs also show the response of water levels to seasonal changes in withdrawals; these fluctuations were as much as $19 \mathrm{ft}$, with wells located closest to pumping centers (9-60 and 9-150) exhibiting the greatest annual variability. The water level in well 9-80, located near the northeastern edge of the cone of depression, shows the least annual variability. The net change in water levels in this well during the 5-year (2003-8), the decadal, and the 30-year periods was negligible. The hydrograph of observation well 9-150, which is located near the southern tip of the peninsula, shows rising water levels from 1979 through the mid-1980s, stabilization through the mid-1990s, and rising levels again from 1998 to 2003. From 2004 through 2008, the near-zero slope of the hydrograph indicates stable groundwater levels. The recovery in water levels in well 9-150 during 1979-86 resulted from the abandonment of public-supply wells in Cape May Point and a decrease in withdrawals from Cape May City's southernmost supply well (Lacombe and Carleton, 2002); rising water levels and the lower amplitude of seasonal fluctuations observed between 1998 and 2004 were the result of further reductions in withdrawals by Cape May City. From 2005 to 2008 , annual variability again increased, although this may be an artifact of an increase in data-collection frequency. The net change during 2003-5 in the water level in well 9-150 was negligible. Well 9-60, located in northern Lower Township 
near LTMUA production wells and less than $1 \mathrm{mi}$ from the WWU Rio Grande well field, had annual high water levels of -7 to $-12 \mathrm{ft}$ and seasonal fluctuations of 10 to $19 \mathrm{ft}$; the summer level was nearly $20 \mathrm{ft}$ below the annual high. Although measurements in this well were made at a rate of only 2 to 3 times per year, an upward slope in the hydrograph can be observed during 2005-8, indicating a rise in water levels corresponding to reductions in withdrawals from the Cohansey aquifer at the well field. Withdrawals from the nearby pumping center remained relatively constant from 1980 through 2006, averaging 3.2 Mgal/d; consequently, the water level in this well shows neither a distinct upward nor downward trend during that period.
Results of the Mann-Kendall trend analysis are listed in appendix 10-1. Temporal density of the data for well 9-60 was not sufficient, and trends were not calculated. No significant upward or downward trends were observed in the remaining Cohansey aquifer wells for the 5-year period from 2003 to 2008; however, a slight downward trend was indicated for well 9-150 during 1998-2008. In contrast, an upward trend was indicated for the 30-year period. Although upward and downward trends were detected at the 95-percent confidence level during several periods at wells 9-49 and 9-80, the slopes of the hydrographs during these periods were negligible, and the magnitude of change was not considered important.

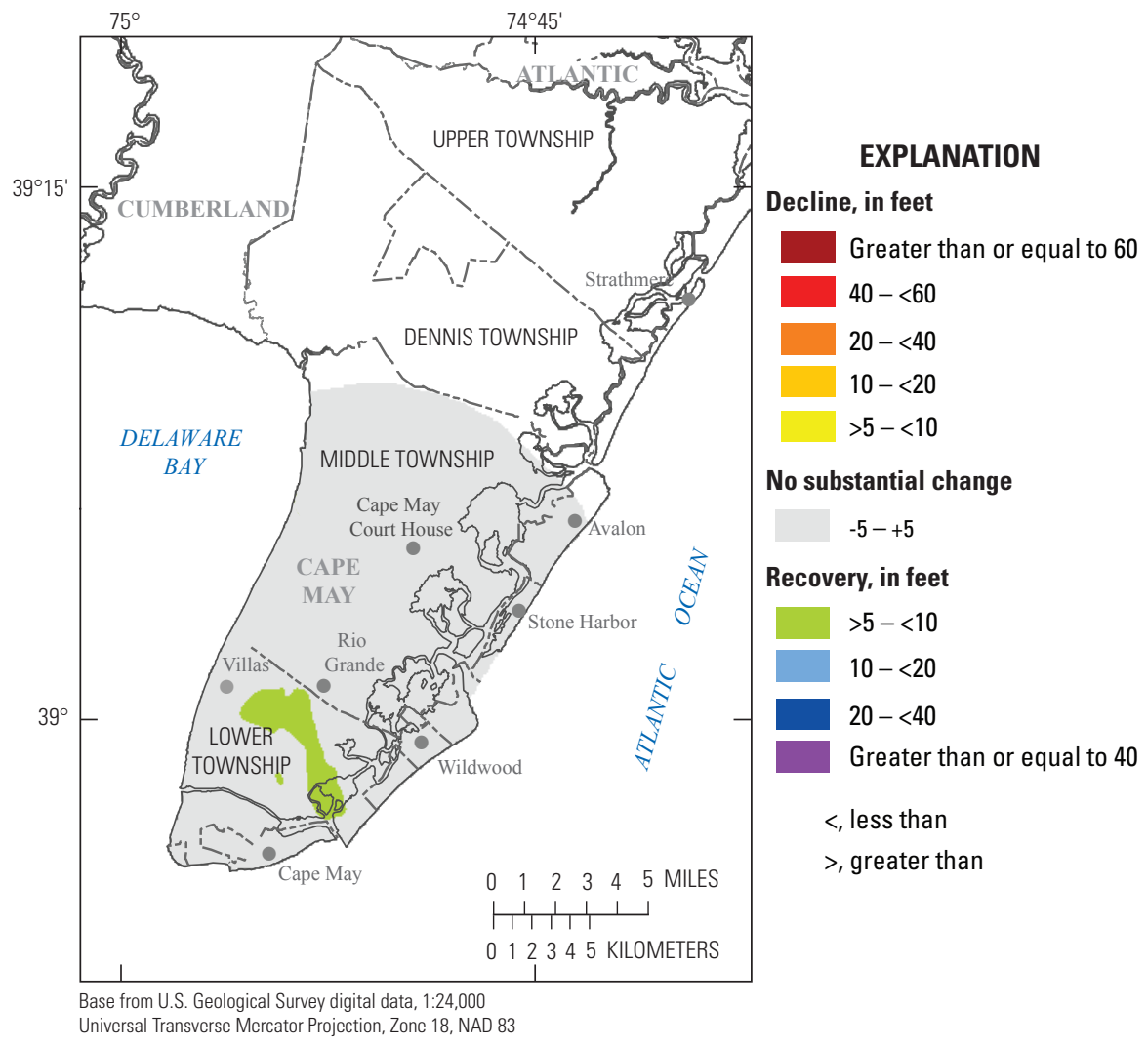

Figure 4. Water-level changes in the confined Cohansey aquifer, Cape May County, New Jersey Coastal Plain, 2003-8. 


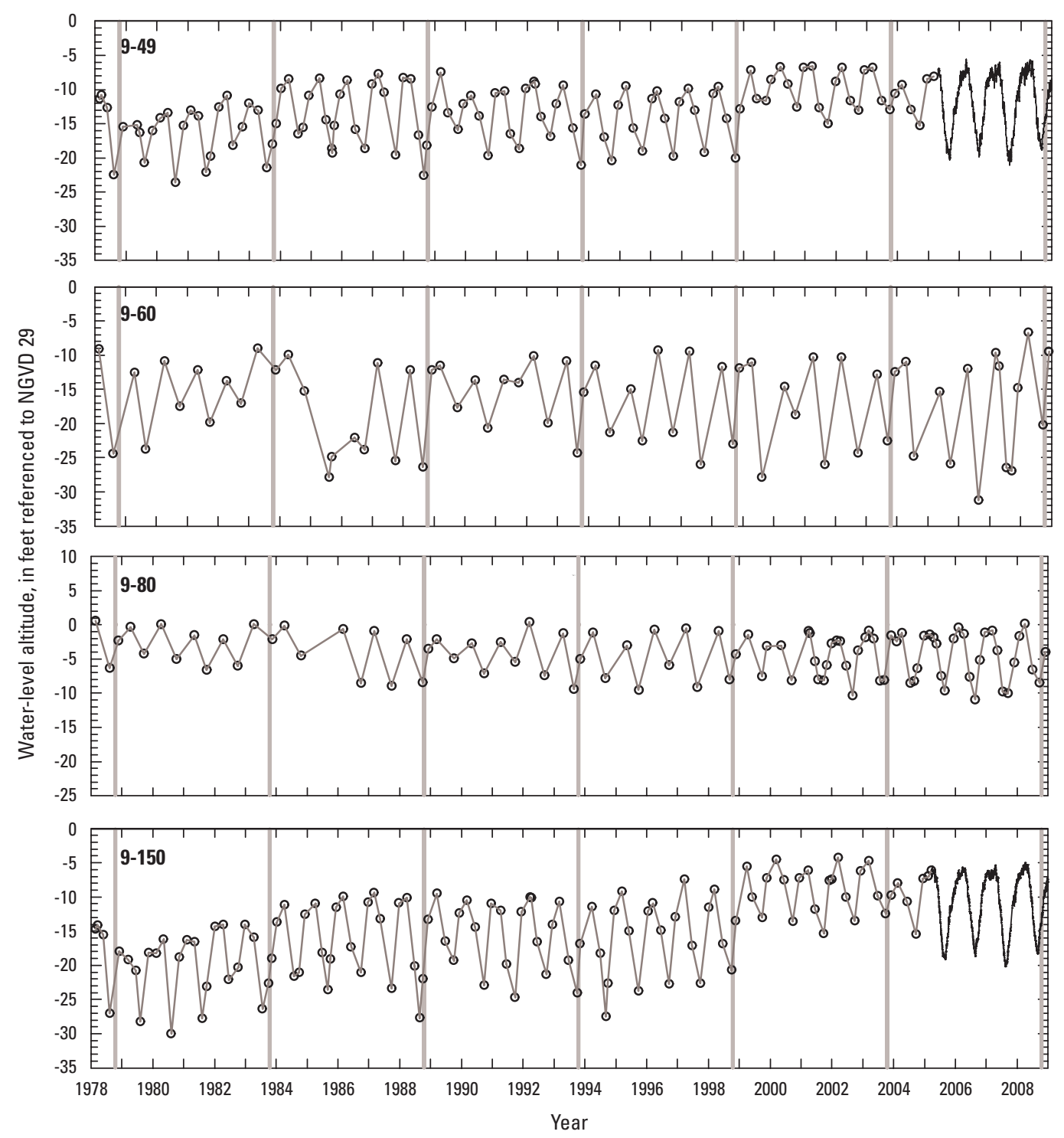

EXPLANATION

Water-level measurement

Continuous

o $\longrightarrow$ Manual

Figure 5. Water-level hydrographs for selected observation wells screened in the confined Cohansey aquifer, Cape May County, New Jersey Coastal Plain, 1978-2008. (All hydrographs are at the same scale; vertical bars denote 5-yr data collection cycles; well locations shown on pl. 1-1) 


\section{Rio Grande Water-Bearing Zone}

The Rio Grande water-bearing zone, as described by Zapecza (1989), is a relatively thin unit composed of coarseto fine-grained sand situated midway within the confining unit that overlies the Atlantic City 800-foot sand. The updip extent of the Rio Grande water-bearing zone approximately coincides with that of the Atlantic City 800 -foot sand, though it is slightly eastward, extending from southern Ocean County through eastern Cumberland County (fig. 1-2 on pl. 1). The Rio Grande water-bearing zone is laterally continuous from Cape May to the southern Ocean County mainland and barrier island beaches; however, the formation pinches out in Egg Harbor Township, Atlantic County, and is generally not recognizable farther updip in this area (Sugarman and Miller, 1997; Zapecza, U.S. Geological Survey, written commun., 2011). The water-bearing zone is approximately $40 \mathrm{ft}$ thick throughout its extent in coastal Ocean and Atlantic Counties (Zapecza, 1989) but thickens considerably in southeastern Cape May where, near Stone Harbor, it is as great as $170 \mathrm{ft}$ thick (Lacombe and Carleton, 2002). Although water levels differ from those in the underlying Atlantic City 800-foot sand, demonstrating substantial hydraulic separation between the aquifers, Lacombe (U.S. Geological Survey, written commun., 2011) showed that geophysical and driller's logs collected at the WWU Rio Grande well field were not definitive regarding the depth and thickness of the confining unit separating the Rio Grande water-bearing zone from the Atlantic City 800-foot sand, resulting in two wells intended for the lower part of the Rio Grande water-bearing zone being installed instead in the upper part of the Atlantic City 800-foot sand.

Fresh groundwater is present within the aquifer underlying coastal regions of the mainland and the barrier islands from its northwestern limit in southern Ocean County southward through most of mainland Cape May County. The aquifer contains saline water south of the canal in southern Cape May County and likely beneath the back bays, barrier islands, and near shore areas along the Atlantic Coast from Avalon to the city of Cape May. Limited available water-quality data provide no evidence of increasing chloride concentrations through 2008. The location of the $10,000-\mathrm{mg} / \mathrm{L}$ isochlor has not been determined for this aquifer but may be near the location of the $10,000-\mathrm{mg} / \mathrm{L}$ isochlor in the underlying Atlantic City 800 -foot sand.

\section{Water Withdrawals}

The Rio Grande water-bearing zone is of minor importance as a source of potable water in New Jersey and is the least utilized of the aquifers included in this study (table 3). Withdrawals from the aquifer totaled approximately 225 million gallons ( $0.6 \mathrm{Mgal} / \mathrm{d})$ during 2008 . Withdrawals are made primarily by water purveyors in Long Beach and Little Egg Harbor Townships in southern Ocean County and in Middle
Township in Cape May County (fig. 6A). Several smallercapacity production wells withdraw water from the aquifer, although the amounts are not thought to be substantial; these wells are located in parts of northern Cape May and eastern Cumberland Counties. Average withdrawals from 1978 to 2008 were less than $1 \mathrm{Mgal} / \mathrm{d}$ (fig. 7A). Withdrawal amounts were apportioned equally between Ocean and Cape May Counties from 1978 to 1988 (approximately 0.3 to $0.4 \mathrm{Mgal} / \mathrm{d}$ ); thereafter, withdrawals generally were greater in Cape May County.

\section{Water Levels}

Groundwater-level data used in preparing the 2008 potentiometric surface for the Rio Grande water-bearing zone are presented in appendix 1-2. The groundwater surface configuration is an elongated cone of depression centered beneath coastal New Jersey extending from the Cape May peninsula northward to Ship Bottom in southern Ocean County (fig. 1-2 on pl. 1). Water levels within the Rio Grande water-bearing zone ranged from a low of -27 ft (well 9-67) in southern Cape May to a maximum of $16 \mathrm{ft}$ (well 9-149) in northwestern Cape May County. As noted by Lacombe and Rosman (2001), the configuration of the regional cone of depression is consistent with the configuration of, and sustained head decline of the cone of depression in, the underlying Atlantic City 800-foot sand, and low water levels observed in downdip parts of the Rio Grande water-bearing zone probably result from downward flow to the Atlantic City 800-foot sand. Locally, withdrawals from the Rio Grande water-bearing zone at the Rio Grande well field in southern Cape May contribute to the low water levels in this vicinity. Water levels at the Rio Grande well field rose by as much as $9 \mathrm{ft}$ relative to 2003 levels as a result of reductions in groundwater withdrawals that began in 2006. In contrast, the water level in well 9-526, $2.2 \mathrm{mi}$ to the west, was $8 \mathrm{ft}$ lower than in 2003 despite the absence of withdrawals from the aquifer (fig. $8 A$ ). Elsewhere, most water levels measured in the Rio Grande water-bearing zone showed small to moderate declines from 2003 (fig. 8A), although withdrawal data indicate little change during the same period. Despite the absence of wells and data, groundwater levels most likely declined throughout eastern and coastal Atlantic County in response to declines in the underlying Atlantic City 800-foot sand. Water-level altitudes in the Rio Grande water-bearing zone were greater than those in the Atlantic City 800 -foot sand throughout the study area; vertical differences increased where heads were most depressed in the underlying aquifer in central and eastern Atlantic County and, to a lesser extent, in southern Cape May County. An upward vertical gradient from the Atlantic City 800-foot sand to the Rio Grande water-bearing zone previously observed at the Rio Grande well field reversed and as of 2008 is downward.

Hydrographs for two observation wells located in Cape May County are shown in figure 9. Water-level data were collected intermittently at these two wells, and distinct long-term 

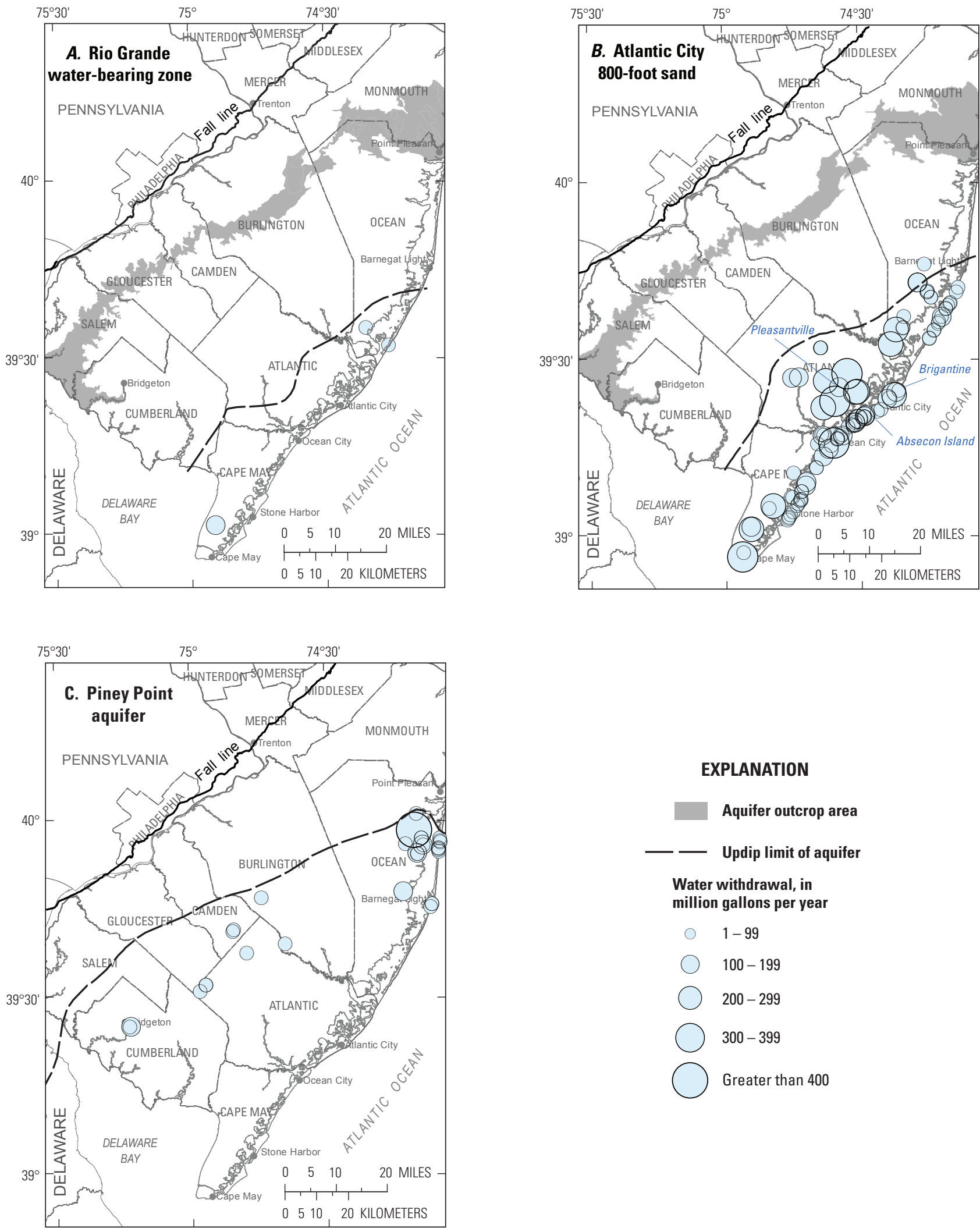

EXPLANATION

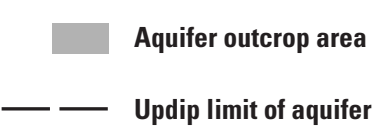

Water withdrawal, in million gallons per year

(1-99

$100-199$

200-299

$300-399$

Greater than 400

Base from U S. Geological Survey digital data, 1:24,000

Universal Transverse Mercator Projection, Zone 18, NAD 83

Figure 6. Location and volume of groundwater withdrawals from $A$, the Rio Grande water-bearing zone, $B$, the Atlantic City 800-foot sand, and $C$, the Piney Point aquifer, New Jersey Coastal Plain, 2008. 


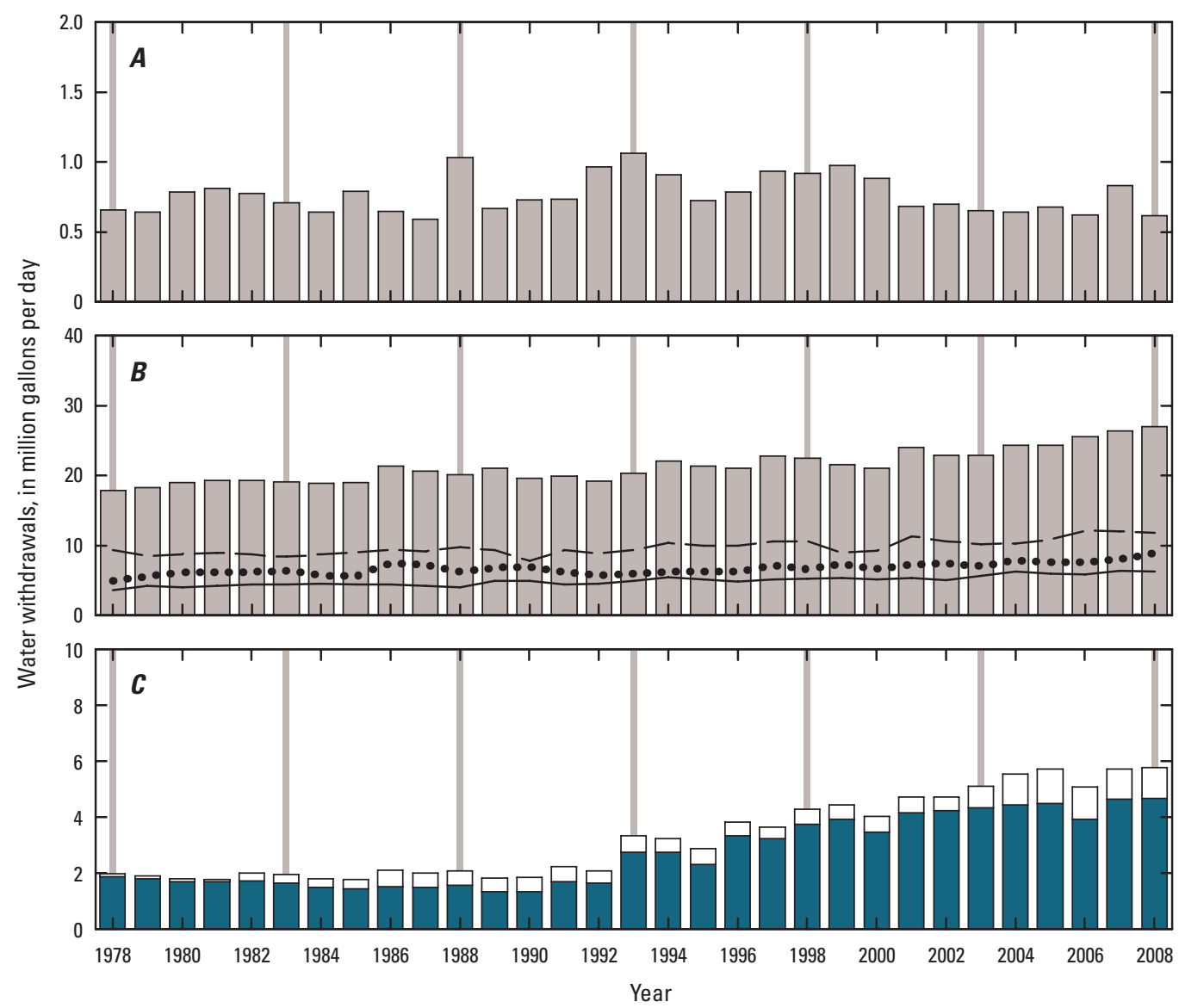

EXPLANATION

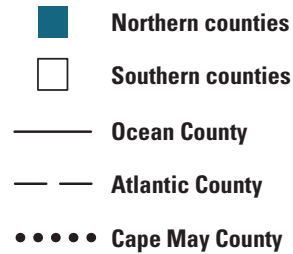

Figure 7. Estimated groundwater withdrawals from $A$, the Rio Grande water-bearing zone, $B$, the Atlantic City 800-foot sand, and $C$, the Piney Point aquifer, New Jersey Coastal Plain, 1978-2008. [Thin vertical bars denote 5-yr data collection periods; note different vertical scaling]

trends are difficult to evaluate. Seasonal fluctuations in water levels are evident at both wells during the early 1990s but are more pronounced in well 9-71 because of its location among production wells at the Rio Grande well field. Data were collected more frequently at well 9-304 than at well 9-71. From 2003 to 2008, the change in the water level in well 9-304 was negligible, but for the period of record, a decline a nearly $7 \mathrm{ft}$ was observed.

Results of the Wilcoxon signed-rank test indicate no significant change in paired samples from 2003 to 2008 (app.
10-2). Water levels increased in 2 wells (17 percent), were unchanged in 1 well ( 8 percent), and decreased in 9 wells (75 percent). One Rio Grande water-bearing zone well had sufficient data for the Mann-Kendall trend test (app. 10-1). Water levels from 2003 to 2008 did not significantly change; from 1998 through 2008, however, there was a statistically significant downward trend, although the annual rate of decline of $0.12 \mathrm{ft} / \mathrm{yr}$ was considered insubstantial. Additional wells within the aquifer need to be identified and data collected in order for substantive interpretations to be made. 

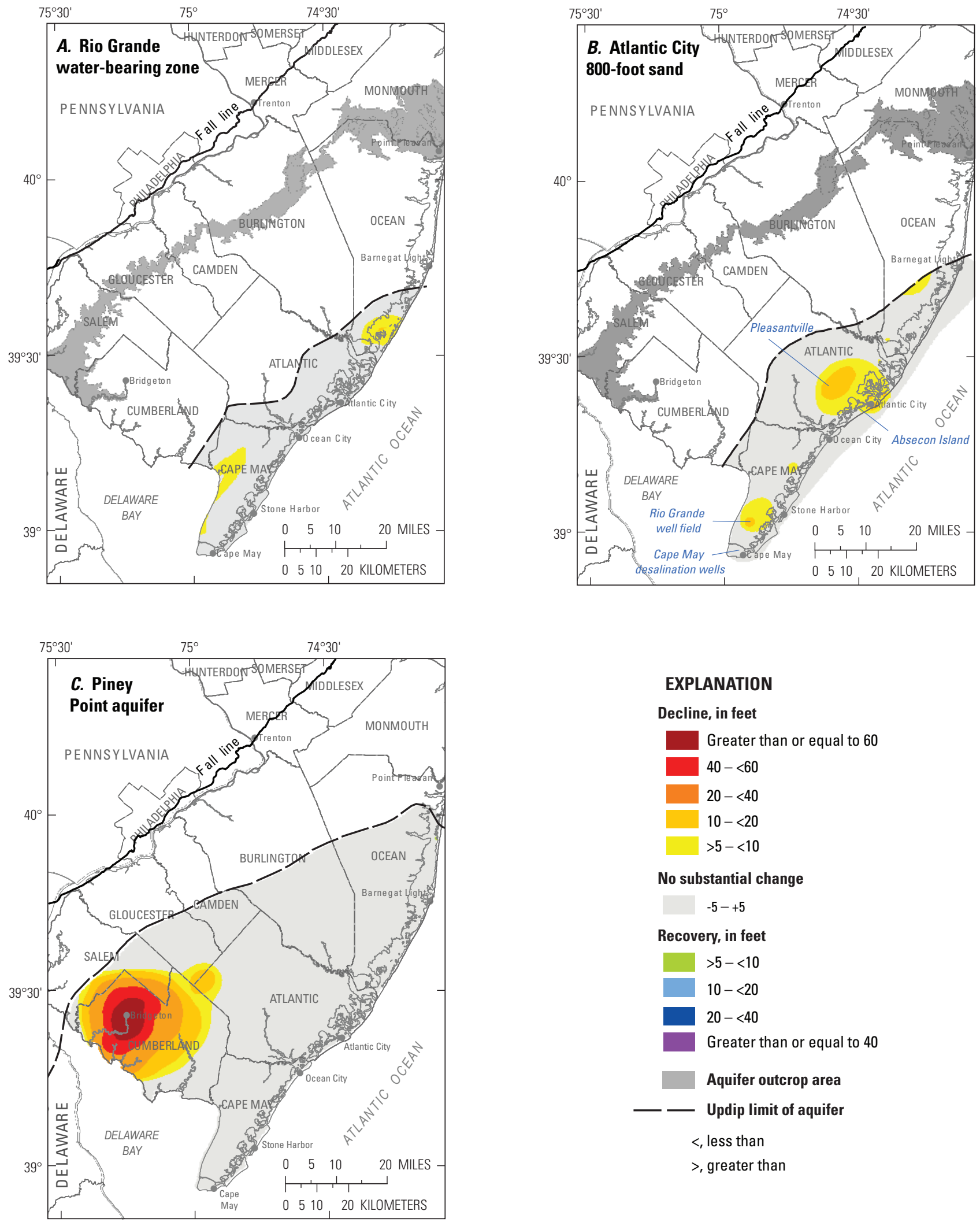

\section{EXPLANATION}

Decline, in feet

Greater than or equal to 60

$40-<60$

$20-<40$

$10-<20$

$>5-<10$

No substantial change

$-5-+5$

Recovery, in feet

$>5-<10$

$10-<20$

$20-<40$

Greater than or equal to 40

Aquifer outcrop area

_—_ Updip limit of aquifer

$<$, less than

$>$, greater than

Figure 8. Groundwater-level changes in $A$, the Rio Grande water-bearing zone, $B$, the Atlantic City 800 -foot sand, and $C$, the Piney Point aquifer, New Jersey Coastal Plain, 2003-8. 


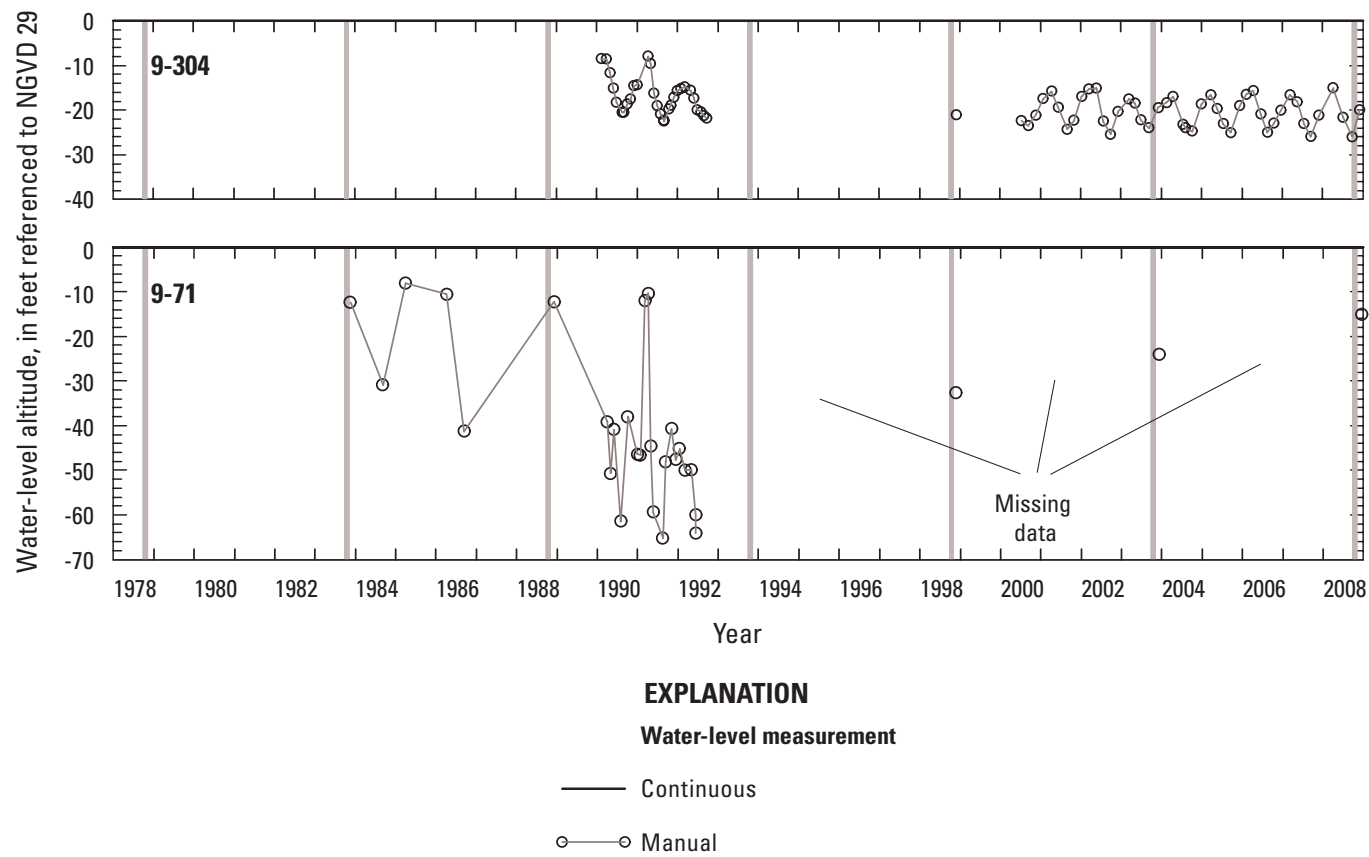

Figure 9. Water-level hydrographs for selected observation wells screened in the Rio Grande water-bearing zone, New Jersey Coastal Plain, 1978-2008. (All hydrographs are at the same scale; vertical bars denote 5-yr data collection cycles; well locations shown on pl. 1-2)

\section{Atlantic City 800-Foot Sand}

The Atlantic City 800 -foot sand, originally named for the depth of production wells in the Atlantic City area, is a major confined aquifer within the Kirkwood Formation. The aquifer is composed of medium- to coarse-grained quartz sands with interspersed shell material. The updip limit of the aquifer is based on the updip limit of the overlying confining unit; however, this confining unit is poorly defined in places. The updip boundary extends, from northeast to southwest, from southern Ocean County 1.7 mi north of Barnegat Light to eastern Cumberland County (pl. 2). The downdip limit of the aquifer is offshore from Ocean, Atlantic, and Cape May Counties. The aquifer thickens downdip and southward from a thickness of $40 \mathrm{ft}$ near Barnegat Light to more than $200 \mathrm{ft}$ at Cape May City (McAuley and others, 2001). Recharge is through vertical flow from the overlying Kirkwood-Cohansey aquifer throughout the extent of the aquifer, although recharge is more substantial near the updip limit where the confining unit is leaky or where the aquifers are in direct contact (Pope, 2006). Recharge also occurs via lateral flow from the KirkwoodCohansey aquifer near the updip boundary.

The Atlantic City 800-foot sand contains freshwater throughout southern Ocean, Atlantic, and northern Cape May Counties where dissolved chloride concentrations typically range from 2 to $20 \mathrm{mg} / \mathrm{L}$. Proceeding south from Avalon, however, the groundwater becomes progressively more chloriderich, and near the southern tip of the Cape May Peninsula, concentrations range from $400 \mathrm{mg} / \mathrm{L}$ to more than $1,500 \mathrm{mg} / \mathrm{L}$.
The estimated position of the $250-\mathrm{mg} / \mathrm{L}$ isochlor is approximately $4 \mathrm{mi}$ to the south-southeast of production wells at Stone Harbor. Concentrations of chloride in groundwater from observation well 9-337, located between the saltwater front and the Stone Harbor pumping center have not increased. At the Stone Harbor production wells nearest the front, chloride concentrations have remained largely constant over time. From the mid-1960s through 2008, concentrations generally ranged from 30 to $40 \mathrm{mg} / \mathrm{L}$, only occasionally exceeded these values, and subsequently returned to antecedent levels. Recently reported chloride concentrations were as high as $87 \mathrm{mg} / \mathrm{L}$, as low as $26 \mathrm{mg} / \mathrm{L}$, and fluctuated with pumping. The highest concentrations typically occurred during the late summer or early fall. Concentrations decreased during the winter and spring. Moreover, recent flow simulations indicate that the $250-\mathrm{mg} / \mathrm{L}$ isochlor will not intersect production wells at Stone Harbor for at least 720 years under various waterallocation scenarios (Pope, 2006). Farther to the north and offshore of Atlantic County, the saltwater front is estimated to be about 9.6 and $8 \mathrm{mi}$ to the southeast of production wells in Ventnor and Brigantine, respectively. Dissolved chloride in samples from production wells at Brigantine remained at concentrations consistently below $8 \mathrm{mg} / \mathrm{L}$ for the period of record through 2008. Similarly, data from production wells at Ventnor showed little or no sustained increase in dissolved chloride concentrations through 2008; for the period 1998 to 2008, reported values only infrequently exceeded $10 \mathrm{mg} / \mathrm{L}$ and were typically below this value. Farther to the south, the estimated saltwater front bisects the southern part of the Cape May 
peninsula, trending approximately east-west from Wildwood to the south of Villas. South of this line, chloride concentrations in groundwater at or near pumping centers increased modestly from 1998 to 2008; concentrations at wells 9-508 and 9-302, although elevated, have remained stable. The estimated location of the $10,000-\mathrm{mg} / \mathrm{L}$ isochlor is approximately $36 \mathrm{mi}$ offshore and to the southeast of Atlantic City.

\section{Water Withdrawals}

The Atlantic City 800 -foot sand is the principal confined aquifer supplying water to New Jersey's barrier island communities from Harvey Cedars in southern Ocean County to Cape May City and as far inland as Mays Landing and Egg Harbor City in Atlantic County. Withdrawals from the aquifer ranged from 17.9 to $27 \mathrm{Mgal} / \mathrm{d}$ during 1978 to 2008 (fig. 7B). Withdrawals have gradually increased since 1978; from any given year to the next increases ranged from 2 to 14 percent, with intervening periods of reduction of generally a few percent or less. Increases of 5 percent or more from the previous year occurred in 1986, 1993 to 1994, 1997, 2001, and 2004. Withdrawals in 2008 averaged nearly $27 \mathrm{Mgal} / \mathrm{d}$, the greatest of the 30-year period from 1978 to 2008. Withdrawal amounts were greatest in Atlantic County and least in Ocean County, where the aquifer thins and becomes less transmissive. From 1978 to 2008, average withdrawals in Atlantic County ranged from 7.8 to $12.0 \mathrm{Mgal} / \mathrm{d}$, gradually increasing throughout the 30 -year period; nearly 60 percent of withdrawals occurred along the barrier islands. Three major pumping centers are within Atlantic County: Absecon Island, Brigantine, and Pleasantville (fig. $6 B$ ). The Pleasantville pumping center is composed of well fields of the Atlantic City Municipal Utility Authority and New Jersey American Water Company-Atlantic and includes several supply wells in eastern Hamilton Township. During 2008, average daily withdrawals from Pleasantville of 5.9 Mgal were greatest among the three pumping centers. Withdrawals ranged from a low of $2 \mathrm{Mgal} / \mathrm{d}$ in 1985 to the highs in 2008. Increases of more than 20 percent from a given year to the next occurred in 1996, 2001, and 2005-6. The Absecon Island pumping center, which includes Atlantic City, Margate, Ventnor, and Longport, historically accounted for a greater percentage of withdrawals than the other pumping centers. During the 1980s, withdrawals from Absecon Island center were equal to the combined withdrawals from the other two centers. In 2005 withdrawals at the Pleasantville and Absecon Island centers were nearly equal, and while withdrawals at the former have since increased, those at the latter decreased. Withdrawals at the Absecon Island pumping center were relatively constant from 1980 to 2006 ; average withdrawals generally fluctuated between 4 and $5 \mathrm{Mgal} / \mathrm{d}$, until reductions during 2007-8. At Brigantine, average withdrawals in 2008 were $1.8 \mathrm{Mgal} / \mathrm{d}$. Withdrawals increased from 1.5 to $2 \mathrm{Mgal} / \mathrm{d}$ during 1980-86; thereafter, combined withdrawals from all wells were approximately $2 \mathrm{Mgal} / \mathrm{d}$.

In Cape May County, most of the groundwater withdrawals were distributed throughout the barrier islands, although substantial withdrawals were also made near Cape May Court House and near Cape May City at the southern end of the peninsula (fig. 6B). From 1978 to 2008, average withdrawals ranged from 5.0 to $8.9 \mathrm{Mgal} / \mathrm{d}$. Withdrawals decreased during 1986-92 from $7.5 \mathrm{Mgal} / \mathrm{d}$ to less than $6 \mathrm{Mgal} / \mathrm{d}$; however, during 1992-2003 withdrawals increased by more than 20 percent. In early 1998, a desalination plant in lower Cape May County began operation to augment existing groundwater supply, and by 2003, associated withdrawals from the aquifer were approximately $1 \mathrm{Mgal} / \mathrm{d}$. During 2003-8, withdrawals throughout the county further increased by 25 percent. In 2008 , withdrawals of $8.7 \mathrm{Mgal} / \mathrm{d}$ represented the greatest total during 1978-2008.

In southern Ocean County, withdrawals from the aquifer were made over nearly the entire length of the barrier island complex; the largest volumes were withdrawn within the mainland communities of Stafford and Little Egg Harbor Townships. Average withdrawals in Ocean County during 2008 were $6.2 \mathrm{Mgal} / \mathrm{d}$, a 9 percent increase from 2003 volumes.

\section{Water Levels}

The 2008 potentiometric surface of the Atlantic City 800 -foot sand is shown on plate 2; groundwater-level measurements used in the preparation of this map are presented in appendix 2. Long-term groundwater withdrawals have created a large, elongated cone of depression that aligns along the general strike of the Kirkwood Formation and extends beneath the coastal barrier island communities from Barnegat Light in Ocean County south to Cape May City. Water levels within the Atlantic City 800-foot sand range in altitude from greater than $40 \mathrm{ft}$ near the updip boundary in central Atlantic County to more than $90 \mathrm{ft}$ below NGVD 29 within the deepest part of the cone, beneath the eastern Atlantic County municipalities of Atlantic City, Margate, and Ventnor. At the northern end of the cone of depression, south of Barnegat Light, water levels ranged from $-29 \mathrm{ft}$ near the northern limit of the confined aquifer to $-35 \mathrm{ft}$ (well 29-9) near the southern end of Long Beach Island. Southwest from the center of the regional cone, water levels were progressively higher toward the southern end of the Cape May peninsula, where the highest water level measured in coastal Cape May County was $-24 \mathrm{ft}$. Two small cones of depression are present in southern Cape May County at the Cape May City (wells 9-479 and 9-480) and WWU well fields.

Groundwater levels measured in 72 wells in 2003 and 2008 were compared to evaluate water-level changes in the Atlantic City 800-foot sand and to map the potentiometric differences (fig. 8B). In 2008, water levels declined in 64 wells ( 89 percent), were unchanged in 4 wells (5.5 percent), and rose in 4 wells ( 5.5 percent). Owing to the substantial increase in withdrawals at the Pleasantville pumping center, groundwater decline was greatest in Atlantic County in an area near the center of the cone of depression, extending throughout the mainland communities of Egg Harbor Township and the city 
of Pleasantville to the barrier island communities of Brigantine, Atlantic City, and Ventnor. From 2003 to 2008 throughout eastern Atlantic County, groundwater-level declines were typically about $9 \mathrm{ft}$ but as great as $16 \mathrm{ft}$. To the north and east, small to moderate declines were observed throughout much of southern Ocean County, were greatest at and near mainland pumping centers, and were smallest along the barrier island. In Cape May County, groundwater-level declines were greatest in the vicinity of the Rio Grande well field. Because not all wells measured in 2008 were available during the 2003 study, water-level data were compared to estimates derived from the 2003 potentiometric surface at those locations, resulting in apparent declines of nearly $25 \mathrm{ft}$ at the Rio Grande well field. These values may overestimate the 5-year decline, whereas the measured change of $-7 \mathrm{ft}$ at an observation well 1 mile (mi) to the east probably underestimates the overall decline in the vicinity of the well field (fig. $8 B$ ). In the vicinity of the Cape May City desalination wells, interspersed but modest declines and rises relative to 2003 were observed.

Results of the Wilcoxon signed-rank test indicate statistically significant differences (declines) in paired measurements during both the 5- and 10-year periods across the aquifer. Given recently (2003-8) declining water levels throughout
Atlantic County, this relationship was strongest during the 5 -year period. Differences (declines) are considered statistically significant among paired measurements throughout the counties of Atlantic, Ocean, and Cape May for the 5-year period, and in Atlantic and Cape May Counties for the 10-year period (appendix 10-2, fig. 8B).

Results of the Mann-Kendall statistical trend test are listed in appendix 10-1. Supporting hydrographs for seven observation wells that depict long-term and seasonal trends in the Atlantic City 800-foot sand from 1978 to 2008 are shown in figure 10. Water-level trends during 2003-8 were downward at six wells; data from the seventh well (1-37) were insufficient for testing. Downward trends were strongest at wells in eastern Atlantic County at and near the center of the cone of depression (wells 1-180, 1-578, and 1-702) and weakest on the western side of the Cape May peninsula (well 9-306). From 1998 to 2008, trends were downward at four wells (1-578, 9-302, 9-306, and 9-337) and insignificant at the remaining three wells (1-37, 1-180, and 1-702). For the 30-year period, significant downward trends were observed at all seven wells. Trend tests for each were run for the periods of record, and trends were downward with rates of decline ranging from 0.5 to $1 \mathrm{ft} / \mathrm{yr}$.

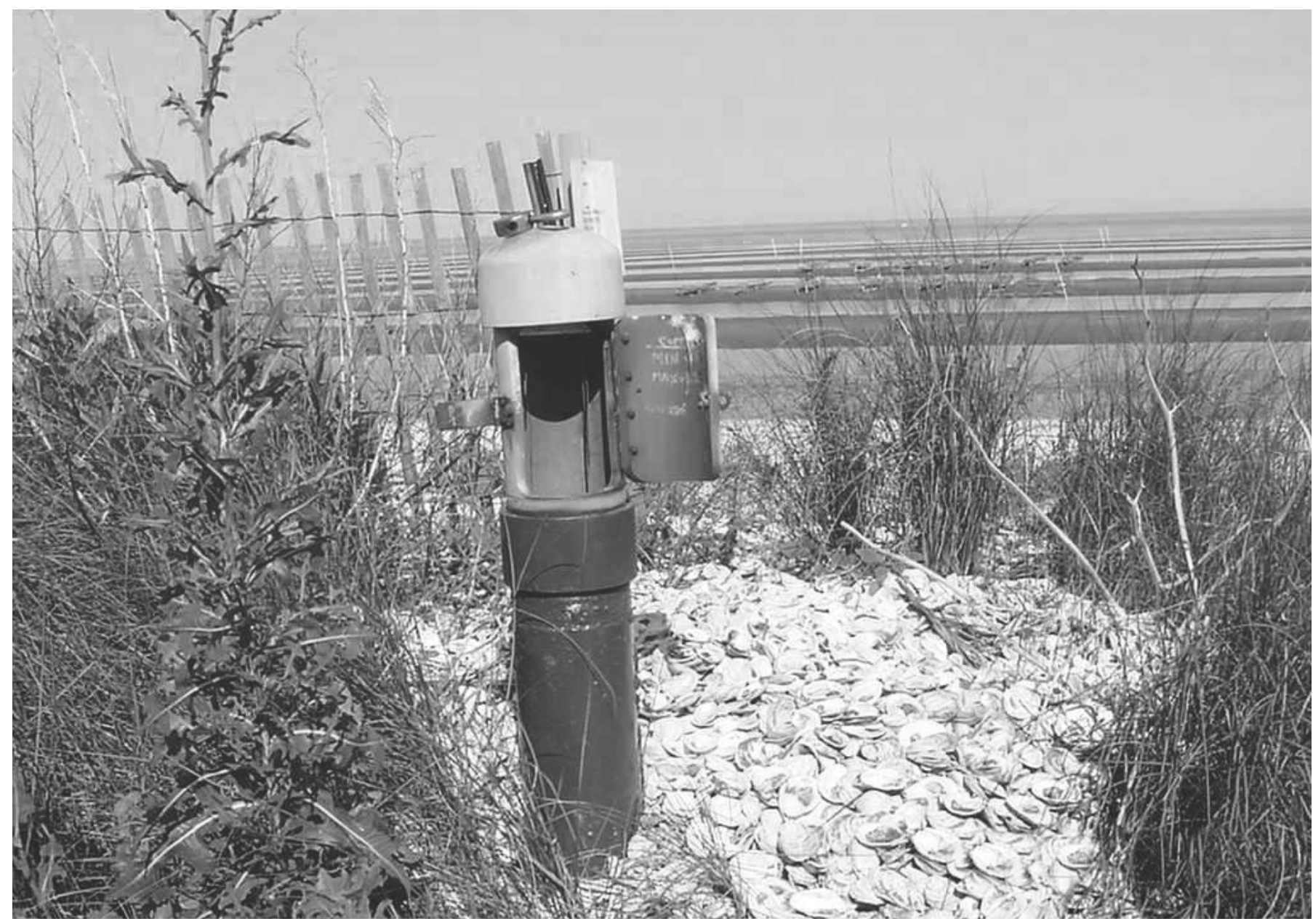

Photograph was provided by U.S. Geological Survey field personnel 

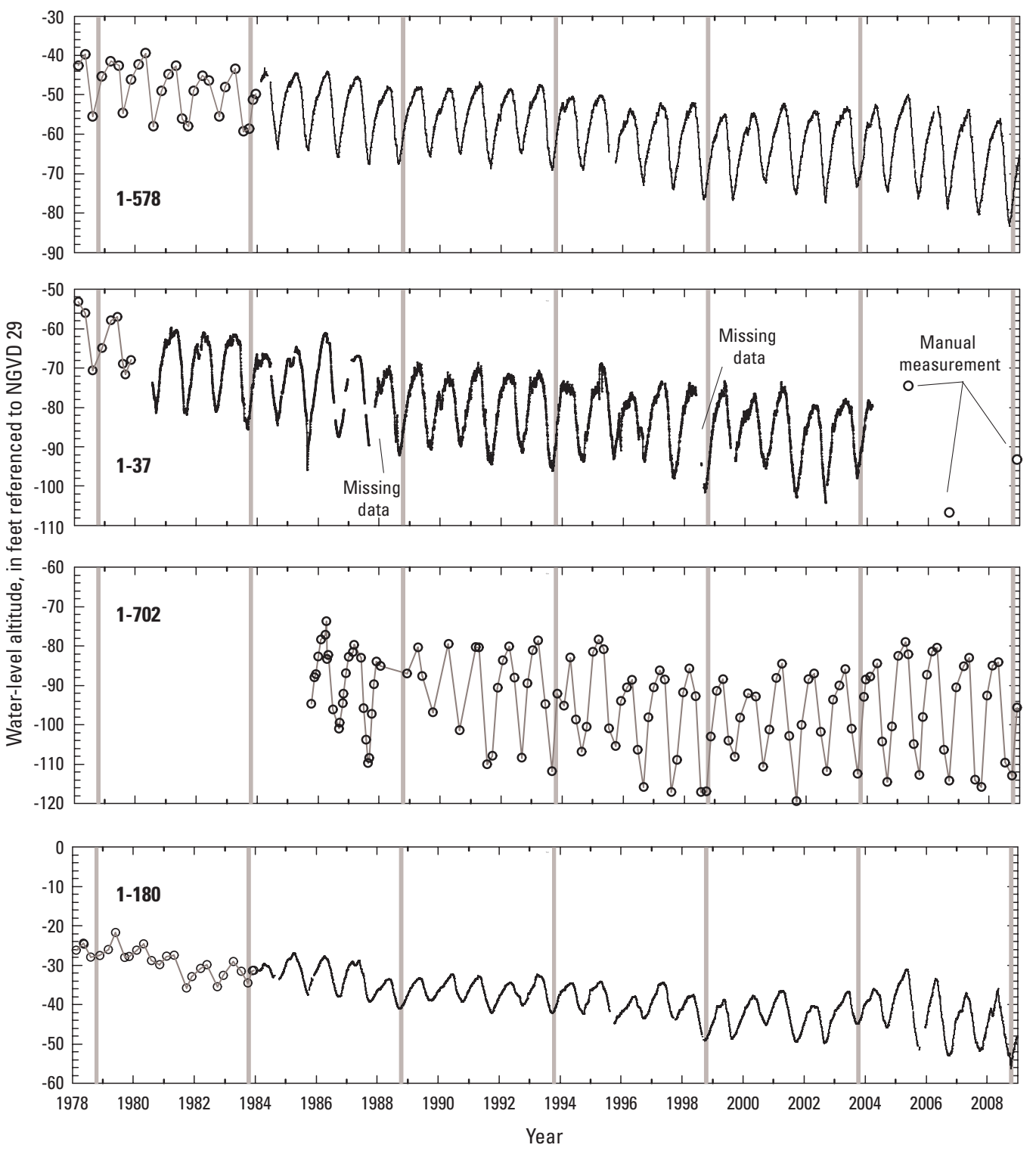

EXPLANATION

Water-level measurement

Continuous

○ $\circ$ Manual

Figure 10. Water-level hydrographs for selected observation wells screened in the Atlantic City 800 -foot sand, New Jersey Coastal Plain, 1978-2008. (All hydrographs are at the same scale; vertical bars denote 5-yr data collection cycles; well locations shown on pl. 2) 


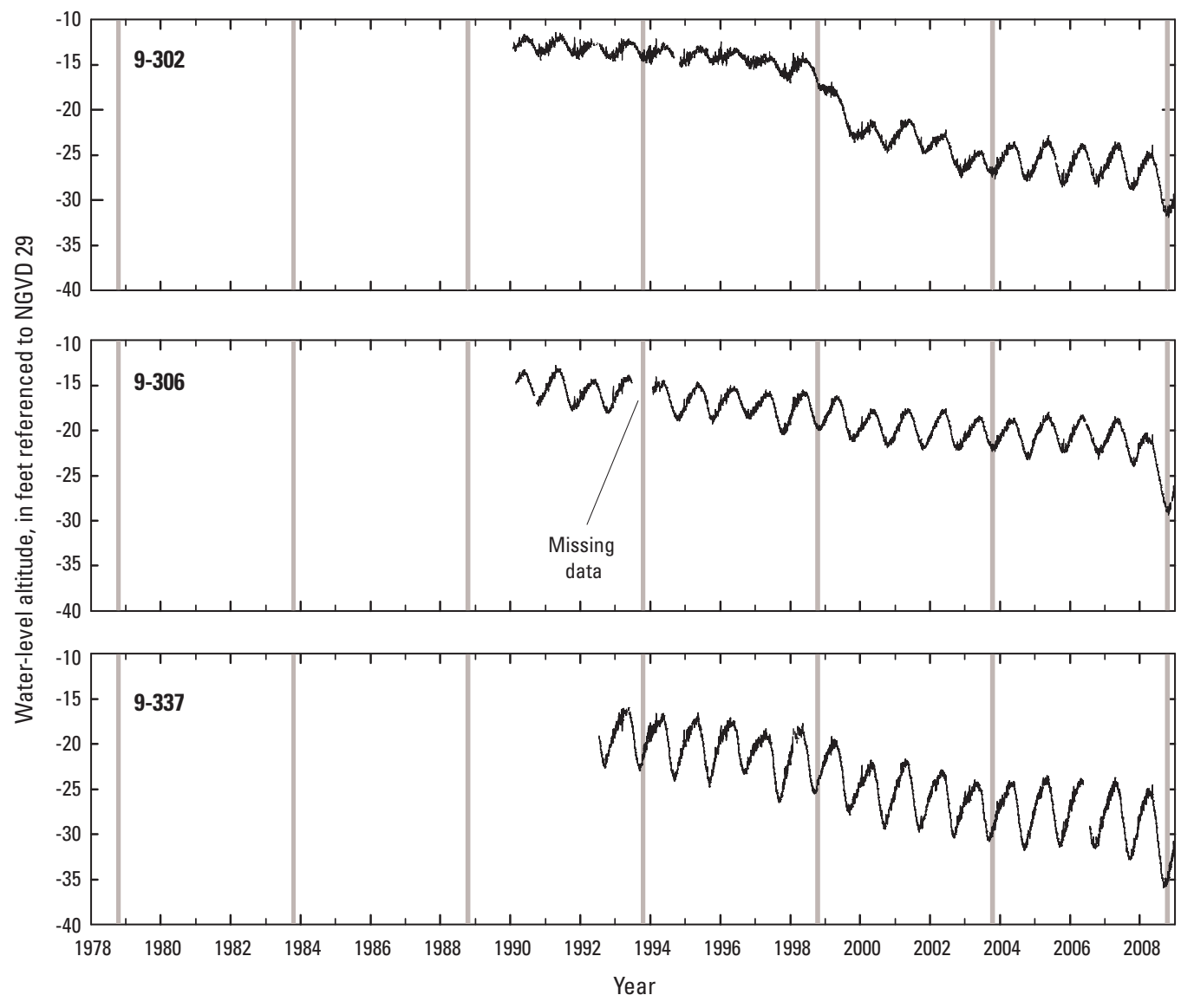

EXPLANATION

Water-level measurement

Continuous

○ O Manual

Figure 10. Water-level hydrographs for selected observation wells screened in the Atlantic City 800-foot sand, New Jersey Coastal Plain, 1978-2008. (All hydrographs are at the same scale; vertical bars denote 5-yr data collection cycles; well locations shown on pl. 2)—Continued 


\section{Piney Point Aquifer}

The Piney Point aquifer, of middle to late Eocene age, is composed of fine- to coarse-grained glauconitic sands interspersed with shell material. The Piney Point aquifer does not crop out within the study area and, therefore, cannot be recharged directly by precipitation; recharge occurs by leakage through confining layers, primarily from the overlying aquifer. The updip limit of the aquifer is in central Ocean, Burlington, Camden, Gloucester, and Salem Counties and approximately near the downdip limit of the Vincentown aquifer. Near this updip limit, the aquifer is generally $40 \mathrm{ft}$ thick. There are two areas within the aquifer extent in New Jersey of substantial sand accumulation (Zapecza, 1989) — southern Burlington and Ocean Counties where thicknesses can exceed $130 \mathrm{ft}$ and, to the southwest, in southern Cumberland County where maximum thicknesses are greater than $200 \mathrm{ft}$. In the former, a greater percentage of coarse-grained materials readily permits the transmission of water and is favorable to development, and in the latter, thin clay beds and clay-silt in the aquifer matrix limit productivity (Sugarman and others, 2005). In Delaware, the Piney Point aquifer is composed of two geologic units, the Piney Point Formation and the basal sand of the Calvert Formation, that together function as a single hydrologic unit (McLaughlin and Velez, 2006). The Piney Point aquifer in Delaware is predominantly an upward coarsening, shelly quartz sand containing glauconite that grades to a muddier facies north and west of the city of Dover. The updip limit of the aquifer is in central Kent County, and the downdip limit extends into southeastern Sussex County (Vroblesky and Fleck, 1991). The maximum thickness of the aquifer in Delaware, approximately $250 \mathrm{ft}$, occurs near the city of Dover.

Groundwater in the Piney Point aquifer is typically a calcium-sodium or sodium-bicarbonate type water that evolves to a sodium-chloride type water in downdip areas. Owing to recharge via vertical flow through the upper confining unit, ion-exchange reactions are likely important determinants of the water chemistry of the aquifer, as evidenced by the enrichment of sodium and potassium relative to chloride (Lettini and others, 2003). Sodium to chloride molar ratios range from 1.8:1 to more than 100:1 with highest ratios present in updip sections and beneath the barrier island complex of central Ocean County, indicative of the greater capacity for cationexchange within the aquifer in these areas. In many areas of the aquifer, sodium concentrations exceeded the NJDEP secondary maximum contaminant level of $50 \mathrm{mg} / \mathrm{L}$. Chloride concentrations in groundwater ranged from 2 to $10 \mathrm{mg} / \mathrm{L}$ throughout much of Ocean and central Burlington Counties but increased to the south and seaward where concentrations exceeded $300 \mathrm{mg} / \mathrm{L}$ in groundwater in coastal Atlantic County. In southern and southwestern New Jersey, concentrations ranged from 1 to $200 \mathrm{mg} / \mathrm{L}$ and increased with decreasing distance to the Delaware Bay. Historical data indicate possible saltwater intrusion into wells at bay front communities in southern Cumberland County; owing to the lack of supporting chemical data, it is unclear whether increases in chloride concentrations resulted from lateral intrusion from the Delaware Bay or from vertical leakage from the overlying aquifer via compromised annular well seals. Further, recent (2008) water-quality data for the aquifer in this area were not available.

For this study, the location of the $250-\mathrm{mg} / \mathrm{L}$ isochlor in New Jersey was modified from Schaefer (1983) and Lacombe and Rosman (2001); in Delaware, the location was mapped by Woodruff (1969) and modified by Lacombe and Rosman (2001). The location of the onshore part of the line extends from eastern Atlantic County southwest to northern Cape May County. To the north, the position of this line was estimated by Lacombe and Rosman (2001) to be 12 mi downdip from production wells at Barnegat Light; however, neither observed nor simulated data were available to substantiate this estimate. The simulated $10,000-\mathrm{mg} / \mathrm{L}$ isochlor is located offshore, approximately $8 \mathrm{mi}$ from production wells at Barnegat Light (Pope and Gordon, 1999). Measured chloride concentrations in production wells at Barnegat Light ranged from 5 to $15 \mathrm{mg} / \mathrm{L}$ but were typically $10 \mathrm{mg} / \mathrm{L}$ or less; sustained increases have not occurred during 1998-2008. Similarly, chloride concentrations in groundwater from observation wells near the saltwater front have not increased substantially, and the extent of freshwater remains similar to that in 2003. In Delaware, the position of the front is approximately $10 \mathrm{mi}$ downdip from the major pumping center at Dover.

\section{Water Withdrawals}

In New Jersey, groundwater withdrawals from the Piney Point aquifer were made predominantly in the coastal region of Ocean County, particularly in the central Barnegat Bay region, in Buena Borough in western Atlantic County, and in and around the city of Bridgeton in southern Cumberland County where water-quality issues in the overlying KirkwoodCohansey aquifer have spurred recent development of the Piney Point aquifer (fig. 6C). Withdrawals from the Piney Point aquifer also are made in the updip parts of the aquifer in southeastern Burlington and Camden Counties in locations where yields are favorable to development. In Delaware, the Piney Point aquifer is a major source of groundwater in Kent County and has long been utilized for supply in and around the city of Dover.

Average withdrawals in New Jersey from the Piney Point aquifer ranged from less than 2 to $5.8 \mathrm{Mgal} / \mathrm{d}$ during 1978-2008 (fig. 7C). Withdrawals from the Piney Point aquifer were relatively minor from 1978 to 1992 at $2 \mathrm{Mgal} / \mathrm{d}$ with most withdrawals in Ocean County and negligible amounts in Atlantic and Cumberland Counties. Withdrawals increased by more than 50 percent from 1992 to 1993 , largely owing to increasing development in the Toms River area. From 1993 to 2002, development of the aquifer in Ocean County continued to expand, and by 2003 withdrawals there accounted for 90 percent $(4.3 \mathrm{Mgal} / \mathrm{d})$ of all withdrawals from the Piney Point aquifer within New Jersey. Combined withdrawals in Atlantic, Burlington, Camden, and Cumberland Counties 
ranged from 0.1 to $0.6 \mathrm{Mgal} / \mathrm{d}$ from 1978 through 2002, followed by increases of 56 and 41 percent in 2003 and 2004, respectively, as withdrawals in the Bridgeton area began.

\section{Water Levels}

The potentiometric surface of the Piney Point aquifer during late fall 2008 in New Jersey and Delaware is shown on plate 3; the groundwater-level data that were used in the analysis are listed in appendix 3 . The maximum groundwater altitude within the Piney Point aquifer (118 ft in well 29-425) occurred near the up-dip extent along the border of Burlington and Ocean Counties, and the minimum (less than $-150 \mathrm{ft}$, various wells) occurred in south-central Cumberland County, New Jersey. The configuration of the 2008 potentiometric surface indicates the presence of six distinct cones of depression. The northernmost cone underlies Seaside Park in Ocean County near the area where the aquifer is most heavily utilized in New Jersey; the minimum water level at the center of this cone of depression was $-45 \mathrm{ft}$ (well 29-1681). To the south, the cone of depression centered beneath Barnegat Light had a potentiometric minimum of -39 ft (well 29-607).

A cone of depression in coastal Atlantic County is consistent with sustained head decline in the overlying Atlantic City 800 -foot sand. The Piney Point aquifer is unused in this area, and the presence of this cone indicates upward leakage in response to lower water levels in the overlying aquifer. Above the Atlantic City 800-foot sand, a cone of depression in the infrequently used Rio Grande water-bearing zone also is an indicator of hydraulic stress propagating through the hydrogeologic section in this area. The 2008 water level at the center of this cone (-38 ft, well 1-834) was approximately $4 \mathrm{ft}$ lower than that observed during the previous study. Water levels in the overlying Atlantic City 800 -foot sand declined as much as $16 \mathrm{ft}$ in this area from the previous study.

Development of the aquifer in Bridgeton, Cumberland County, after 2003 caused a deep and regionally extensive cone of depression to form within an area already characterized by persistent potentiometric lows and long-term gradual declines in water levels as a result of withdrawals at Dover, Delaware. Yields within the Piney Point aquifer vary at different locations because of variations in hydraulic conductivity that result from facies changes within the Piney Point Formation. The depth and extent of this cone are greater than expected given the relatively small amounts of groundwater withdrawn. Measured water level altitudes at the pumping center in Bridgeton ranged from -154 to $-157 \mathrm{ft}$; a subsequent review of purveyor-collected data reported throughout 2009 confirmed these observations (NJDEP, 2012). With the introduction of the supply wells in Bridgeton and the deepening of the cone of depression, the hydraulic gradient was somewhat reversed, forming a groundwater divide within the aquifer beneath the Delaware Bay. Groundwater that previously flowed beneath the bay from New Jersey toward pumping centers in Dover is now partially captured by production wells at Bridgeton.
In Delaware, a cone of depression, with a minimum water-level altitude of $-138 \mathrm{ft}$ (well Jd14-15) persists in and around the city of Dover. This cone is the most regionally extensive within the Piney Point aquifer in the study area. Substantial long-term withdrawals in Dover placed significant hydraulic stress on the aquifer with the breadth of effects extending throughout a large area beneath the Delaware Bay and into southern New Jersey. Until 2004, the longterm withdrawals were the primary cause of declining water levels in the Piney Point aquifer in Cumberland County. The potentiometric surface shows a slight deepening and apparent movement of the center of the cone to the north; this change is probably a result of spatial shifts in the withdrawal patterns or the configuration of the water levels relative to those of previous studies.

In updip areas of the aquifer, vertical head differences between the overlying Kirkwood- Cohansey aquifer and the Piney Point aquifer were greatest in Camden, Gloucester, Cumberland, and western Atlantic Counties, and flow is downward, recharging the aquifer. A downward vertical gradient to the Piney Point aquifer persists throughout much of Ocean County; however, in southern Burlington County estimated heads were generally higher in the Piney Point aquifer, particularly in low-lying areas near the Batsto and Mullica Rivers, resulting in a strong upward vertical gradient that is demonstrated by the presence of flowing artesian wells. Vertical head differences between the Piney Point and the Wenonah-Mount Laurel aquifers indicate strong downward gradients and the potential for flow out of the Piney Point aquifer in central Burlington, Camden, and Gloucester Counties, particularly in areas where the underlying Wenonah-Mount Laurel aquifer is stressed, such as in Winslow and Monroe Townships (Williamstown quadrangle). Vertical water-level differences range from 60 to $80 \mathrm{ft}$ in this area, and maximum differences may exceed $100 \mathrm{ft}$. In south-central Cumberland County, estimated vertical differences within the regional cone of depression exceed $150 \mathrm{ft}$ both above and below the Piney Point aquifer; thus there is the potential for induced flow from both the underlying and overlying units into the Piney Point aquifer.

In the northern extent of the aquifer, vertical differences between the Piney Point and Wenonah-Mount Laurel aquifers diminish in the downdip direction, and the potential for a downward gradient lessens. At the northernmost cone of depression in the Piney Point aquifer in Ocean County, the vertical gradient reverses, and flow is upward into the Piney Point aquifer. At Barnegat Light and immediately to the south, a potential downward vertical gradient into the Piney Point aquifer from the transitional area of the Kirkwood-Cohansey aquifer system and the Atlantic City 800-foot sand is present. From Harvey Cedars and proceeding down the coast, the gradient reverses and strengthens. Near Atlantic City, vertical head differences are as great as $60 \mathrm{ft}$, and flow is upward from the Piney Point aquifer into the overlying Atlantic City 800 -foot sand. This potential upward gradient weakens south and to the west; however, vertical head differences between the two units remain substantial throughout Cape May County 
(where Piney Point aquifer water levels are believed to be higher than -20 ft and Atlantic City 800-foot sand water levels are known to be generally lower than $-20 \mathrm{ft}$ and as low as $-60 \mathrm{ft})$.

Of the confined aquifers included in this study, groundwater levels in the Piney Point aquifer changed more from 2003 to 2008 than water-levels in other units in terms of mean $(-14 \mathrm{ft})$ and maximum $(-136 \mathrm{ft})$ change. Although water levels were essentially unchanged or had recovered throughout much of the State (fig. 8C), declines exceeding $130 \mathrm{ft}$ were observed in southern New Jersey. Of the 50 wells measured in both 2003 and 2008, groundwater levels declined in 38 (76 percent), remained about the same in 4 ( 8 percent), and rose in 8 (16 percent) wells. Stable groundwater levels to a slight recovery of groundwater levels were observed throughout southern Ocean, Burlington, and parts of northern Atlantic Counties. Moderate to large declines were most common at the cones of depression in western Atlantic and Cumberland Counties in New Jersey and Kent County in Delaware (fig. 8C). In Bridgeton, Cumberland County, moderate withdrawals created a deep cone of depression and caused groundwater levels to decline more than $130 \mathrm{ft}$ at the center of the cone and from 25 to $60 \mathrm{ft}$ through much of Cumberland County. In western Atlantic County, the cone of depression centered beneath the Borough of Buena widened and deepened as groundwater levels declined $17 \mathrm{ft}$ relative to 2003 levels. Although withdrawals from borough wells increased during 2003-8, declining groundwater levels probably were, to some degree, affected by the expansion of the area with water levels below NGVD 29 throughout Cumberland County.

Moderate groundwater-level declines were observed in most wells in Kent County, Delaware. Near Dover, declines ranged from $9 \mathrm{ft}$ to $17 \mathrm{ft}$ with the largest declines occurring near the center of the cone of depression and the most temperate declines to the south and west.

Results of the Wilcoxon signed-rank test indicate significant differences in the paired water-level measurements throughout the dataset as a whole for both the 5-year and the decadal period. Given steeply declining groundwater levels in southern New Jersey during 2004-8, this relation was strongest for the 5-year period. Repeated measurements made at individual wells were not available in sufficient numbers to group and test by county, except for Ocean County, where no differences were detected during either period, indicating that statistical significance is attained on the basis of changes observed in wells in southern New Jersey.

Results of the Mann-Kendall statistical trend test are listed in appendix 10-1. Hydrographs for 13 observation wells that show long-term and seasonal trends for the Piney Point aquifer in New Jersey and Delaware are provided in figures 11 and 12. Downward trends during 2003-8 were observed at seven wells, most notably at wells in southern Cumberland County-11-44, 11-96 and 11-163 - where annual rates of decline exceeded 9, 6, and $7 \mathrm{ft} / \mathrm{yr}$, respectively. Slight downward trends were observed at wells 1-834, 5-407, 29-18, and 29-585 located in downdip areas of Atlantic, Burlington, and Ocean Counties, respectively. At two wells located in updip and mid-dip areas of Burlington and Ocean Counties (5-676 and 29-425), no significant upward or downward trend was observed. Results were similar for the 10- and 30-year periods; statistically significant downward trends were detected at observation wells in Atlantic and Cumberland Counties. No significant trend was detected at well ID55-01, located near Dover, Delaware, for the period 2003 to 2008; however, downward trends were observed for both the 10 -year and 30-year periods.

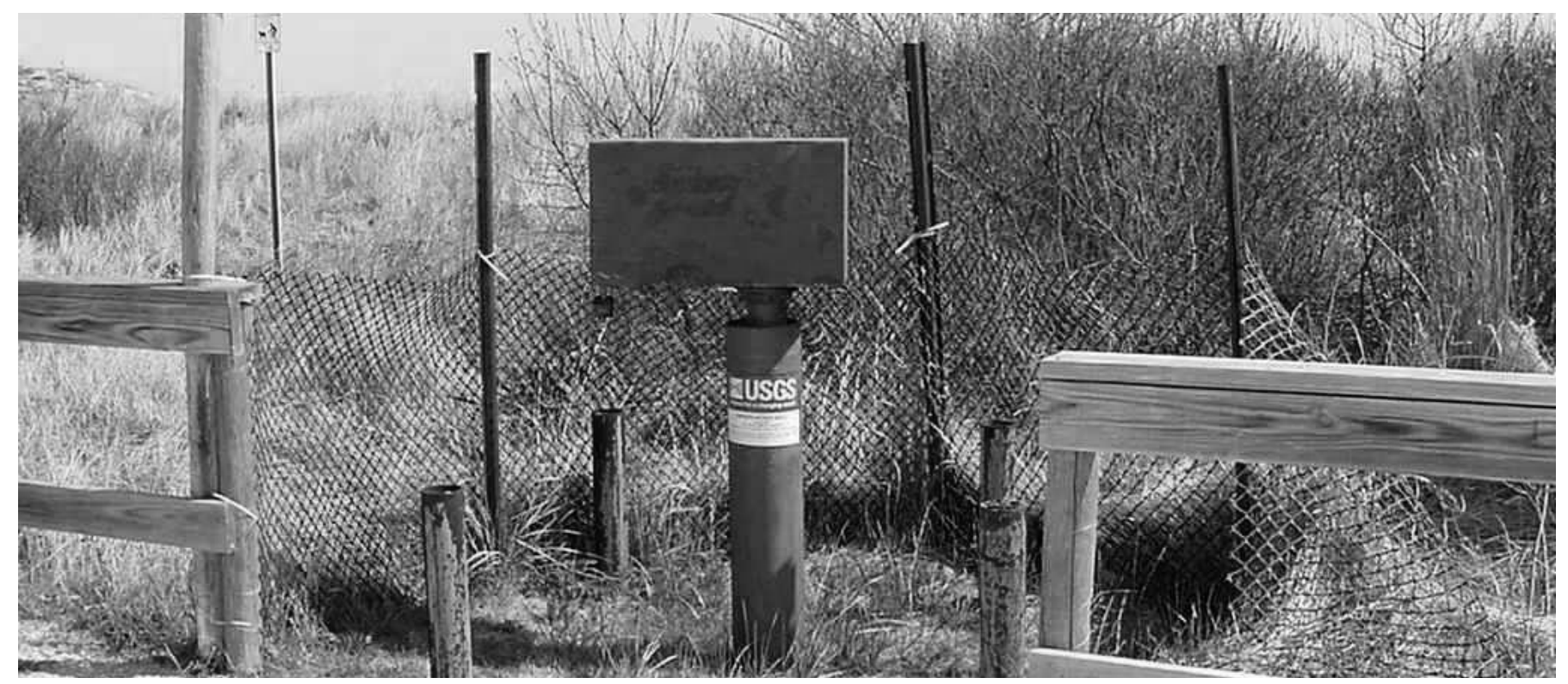

Photograph was provided by U.S. Geological Survey field personnel 


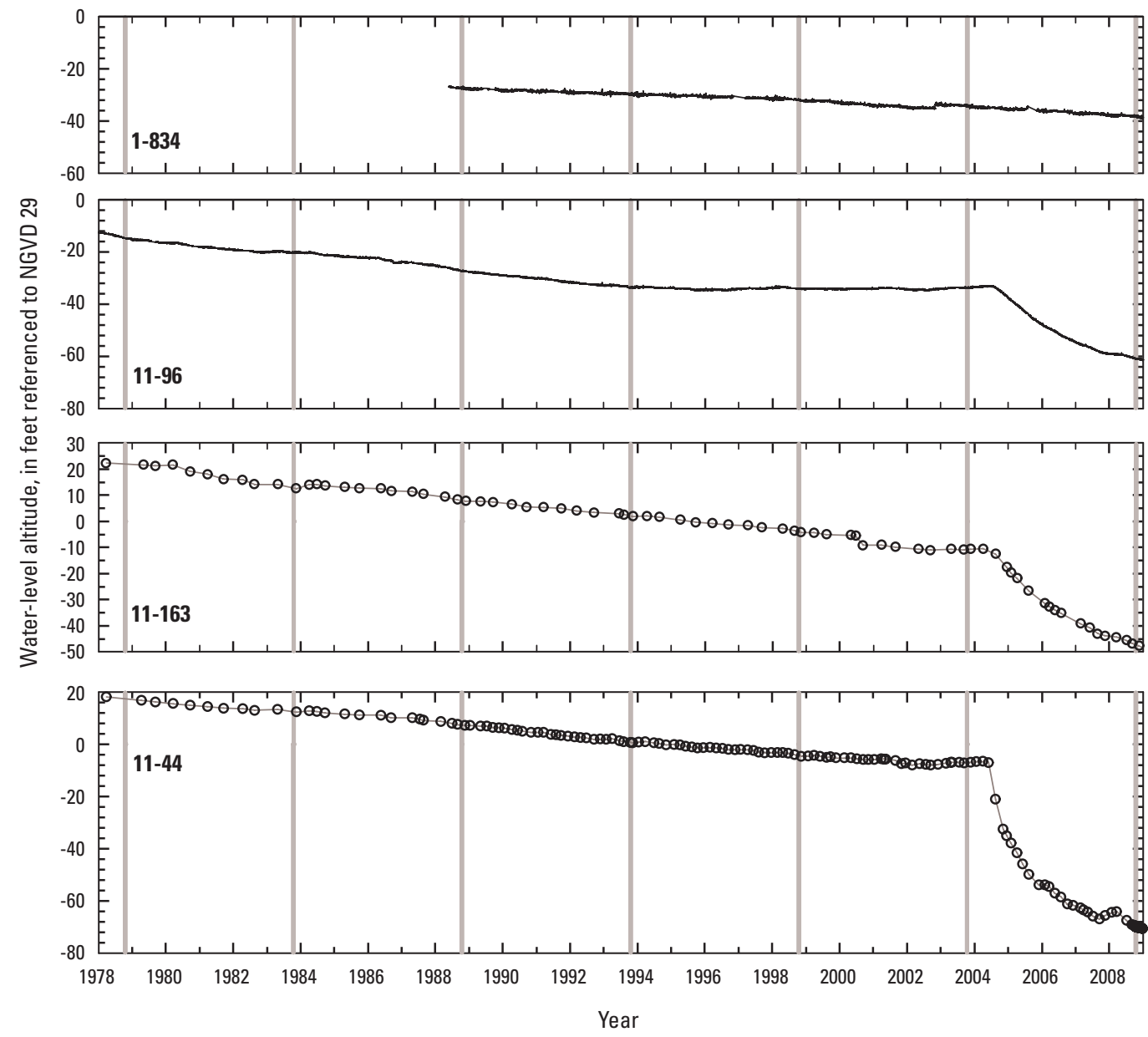

EXPLANATION

Water-level measurement

Continuous

○ M Manual

Figure 11. Water-level hydrographs for selected observation wells screened in the Piney Point aquifer, New Jersey Coastal Plain, 1978-2008. (All hydrographs are at the same scale; vertical bars denote 5-yr data collection cycles; well locations shown on pl. 3) 


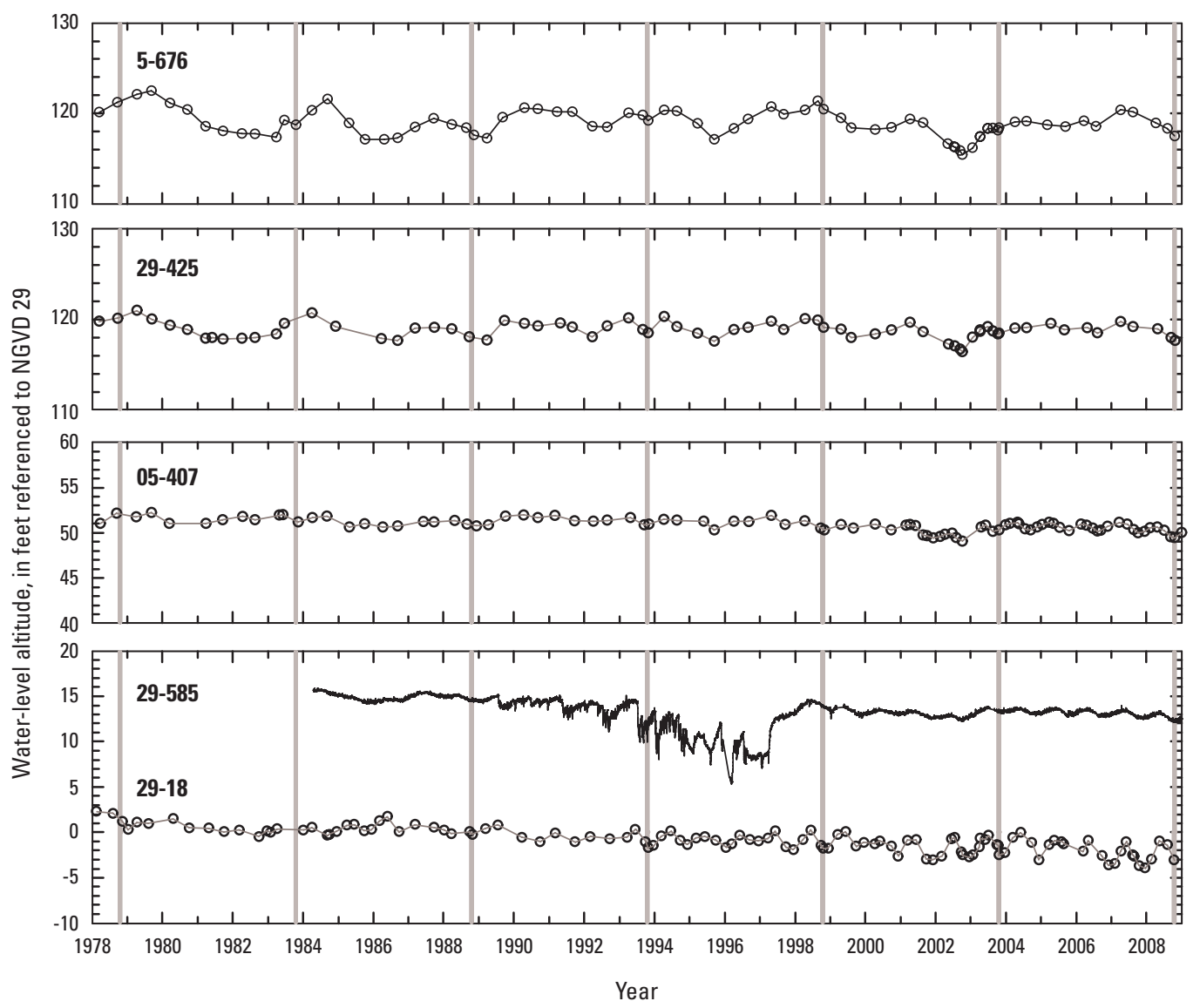

EXPLANATION

Water-level measurement

- Continuous

- o Manual

Figure 11. Water-level hydrographs for selected observation wells screened in the Piney Point aquifer, New Jersey Coastal Plain, 1978-2008. (All hydrographs are at the same scale; vertical bars denote 5-yr data collection cycles; well locations shown on pl. 3)Continued 


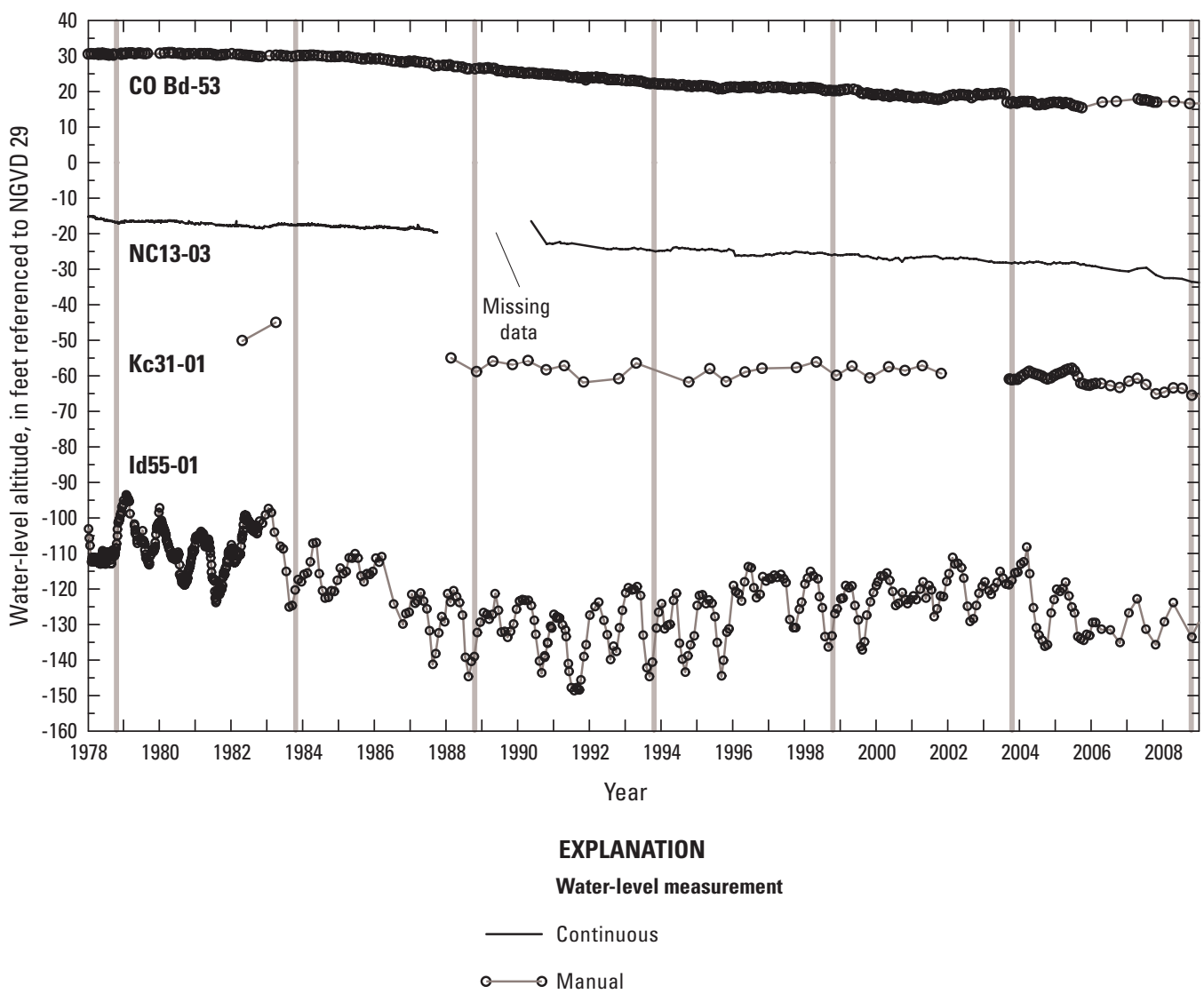

Figure 12. Water-level hydrographs for selected observation wells screened in the Piney Point aquifer, Delaware and eastern Maryland, 1978-2008. (Vertical bars denote 5-yr data collection cycles; well locations shown on pl. 3)

\section{Vincentown Aquifer}

The Vincentown aquifer is composed of the sandy parts of the Paleocene Vincentown Formation. Within the outcrop and from 8 mi to 10 mi downdip, the Vincentown Formation can yield quantities of groundwater capable of sustaining small production and domestic-supply wells; beyond this extent, it functions primarily as a confining unit (Zapecza, 1989). In the outcrop and the shallow subsurface, the formation is composed primarily of a massive quartzose sand containing abundant glauconite, mica, and shell material. The formation grades to silty sand then to silt downdip from the outcrop (Sugarman, 1992). The formation is thickest (more than $100 \mathrm{ft}$ thick) in Monmouth County, the area where it is most often used for water supply. The aquifer is well defined in northern Ocean and southern Monmouth Counties but is less well defined in the rest of the Coastal Plain. Beyond Monmouth and Ocean Counties, the Vincentown Formation is silty and produces appreciable quantities of water only locally; the
Vincentown Formation is not a significant source of water in any part of southwestern or south-central New Jersey.

The Vincentown aquifer is recharged by direct infiltration of rainfall on outcrop areas and in areas where the overlying confining unit is thin or absent. The aquifer also receives recharge from the lower part of the Kirkwood-Cohansey aquifer where the overlying confining unit is thin or leaky. The Vincentown aquifer contains freshwater throughout its confined extent. Chloride concentrations range from 1 to $20 \mathrm{mg} / \mathrm{L}$ throughout the northern counties; in southern counties, concentrations range from 1 to $25 \mathrm{mg} / \mathrm{L}$. Locally, greater concentrations are present in groundwater within the outcrop, likely owing to anthropogenic sources such as road deicers, agricultural chemicals, and septic system effluent. Despite presumed hydraulic contact between the aquifer and the Atlantic Ocean and the aquifer and the lower Delaware River, no evidence of saltwater intrusion exists. Because of the low to moderate chloride concentrations in groundwater, the $250-\mathrm{mg} / \mathrm{L}$ isochlor was not determined for the Vincentown aquifer. 


\section{Water Withdrawals}

Groundwater withdrawals from the Vincentown aquifer are most common in Monmouth County and parts of northern Ocean County. The aquifer in this area is used for public supply, but it also is an important source for domestic and irrigation supply (fig. 13A). Withdrawals for self supply and irrigation are made from the sandy parts of the aquifer in Salem and Burlington Counties and, to a lesser extent, in Gloucester and Camden Counties. Groundwater withdrawals from the Vincentown aquifer ranged from 0.8 to $1.5 \mathrm{Mgal} / \mathrm{d}$ from 1978 to 2008 (fig. 14A). From any given year to the next, withdrawals increased or were reduced by relatively large percentages, ranging from 5 to 44 percent. Average withdrawals during 2008 were $1.1 \mathrm{Mgal} / \mathrm{d}$ with more than 95 percent occurring throughout Ocean and Monmouth Counties. Production wells located in close proximity to the Metedeconk River, which forms the border between northern Ocean and southern Monmouth Counties, accounted for nearly 65 percent $(0.7 \mathrm{Mgal} / \mathrm{d})$ of total reported withdrawals from the aquifer.

\section{Water Levels}

The 2008 potentiometric surface map for the Vincentown aquifer is shown on plate 4; supporting water-level data are presented in appendix 4. Where water-level data were sparse, particularly in southwestern New Jersey, previously published potentiometric surface maps (DePaul and others, 2009), as well as simulated water levels from Voronin (2004), were used to estimate the position and shape of the contours. The configuration of the potentiometric surface for the Vincentown aquifer is nearly identical to that interpreted for 2003; however, small declines in water-level altitudes are indicated by a slight updip and northeastern shift in the mapped contours relative to 2003. The highest groundwater-level altitudes occurred near the updip limit in western Monmouth and northwestern Ocean County in areas of greatest topographic relief; the lowest observed water-level altitudes occurred in coastal Monmouth and Salem Counties in the northeastern and southwestern extent of the aquifer, respectively. A potentiometric high in northern Ocean County, indicated by the $160 \mathrm{ft}-$ contour, reflects prevailing water-table altitudes in the outcrop. Groundwater flow in Monmouth, Ocean, and northern Burlington Counties is generally to the east-southeast from areas of high water-level altitudes near the updip boundary in the west toward areas of discharge to pumped wells and the Atlantic Ocean and toward the eastern areas at the downdip limit of the aquifer where flow recharges the underlying Wenonah-Mount Laurel aquifer.

The lack of accessible wells in Burlington and Camden Counties precluded mapping of 2008 conditions, although the infrequent usage of the aquifer here would indicate that water levels remain essentially unchanged and the potentiometric surface has a configuration similar to that simulated by Martin
(1998). The limited water-level data for central Gloucester County indicate that a local potentiometric high, originally mapped by Hardt and Hilton (1969) and confirmed by DePaul and others (2009), is present. Potentiometric lows of near $0 \mathrm{ft}$ observed during previous studies where the aquifer underlies the Salem River and Delaware estuary were not confirmed in 2008 owing to the loss of observation wells in southwestern Salem County. Reported static water levels at several irrigation wells (not shown on map) during 2008, however, confirm the presence of low water-level altitudes in Salem County. Groundwater altitudes progressively decrease to the southwest of the potentiometric high in Gloucester County, indicating regional flow toward the Delaware River.

Vertical water-level differences between the Vincentown aquifer and the overlying Kirkwood-Cohansey aquifer are generally less than $20 \mathrm{ft}$ in Monmouth and Ocean Counties; a weak to moderate downward hydraulic gradient to the Vincentown aquifer from the water-table aquifer is present and increases in the downdip direction toward the east. In central and southern New Jersey, vertical water-level differences are as great $60 \mathrm{ft}$, indicating a downward gradient from the watertable aquifer to the Vincentown aquifer. A downward vertical gradient is present from the Vincentown to the WenonahMount Laurel aquifer throughout most of Monmouth and Ocean Counties, strengthening toward the downdip boundary of the Vincentown aquifer where water-level altitudes ranged from 40 to $80 \mathrm{ft}$ higher than in the underlying Wenonah-Mount Laurel aquifer. In areas where localized potentiometric highs in the Wenonah-Mount Laurel aquifer coincide with the downdip boundary of the Vincentown aquifer, groundwater-level altitudes are similar and vertical gradients are nearly neutral. At limited observation wells in southern New Jersey, a downward gradient that weakens to the southwest was apparent.

Substantive interpretations of water-level changes could not be made for the extent of the aquifer in 2008, given the spatial limitations of the data collected at individual wells during both studies. Of the 21 wells measured during both the 2003 and 2008 studies, water levels declined in 15 (72 percent), remained the same in 3 (14 percent) and rose in 3 (14 percent) of wells. Water-level changes were minor, owing to the relative constancy of withdrawals, and generally declined or rose by 1 to $3 \mathrm{ft}$. Declines of 5 or $6 \mathrm{ft}$ occurred at four wells, but no spatial patterns are apparent. Declines were not always associated with withdrawals from the aquifer (fig. 13, 15A).

Results of the Wilcoxon signed-rank test indicate significant declines in the paired water-level measurements throughout the dataset as a whole for the 5-year period, but no significant change was observed for the 10-year period (appendix 10-2). Long-term water-level data collected at three wells open to the Vincentown aquifer are represented in figure 16; results of the trend test are provided in appendix 10-1. No significant upward or downward trends were detected at any well for the 5-, 10-, or 30-year periods. 

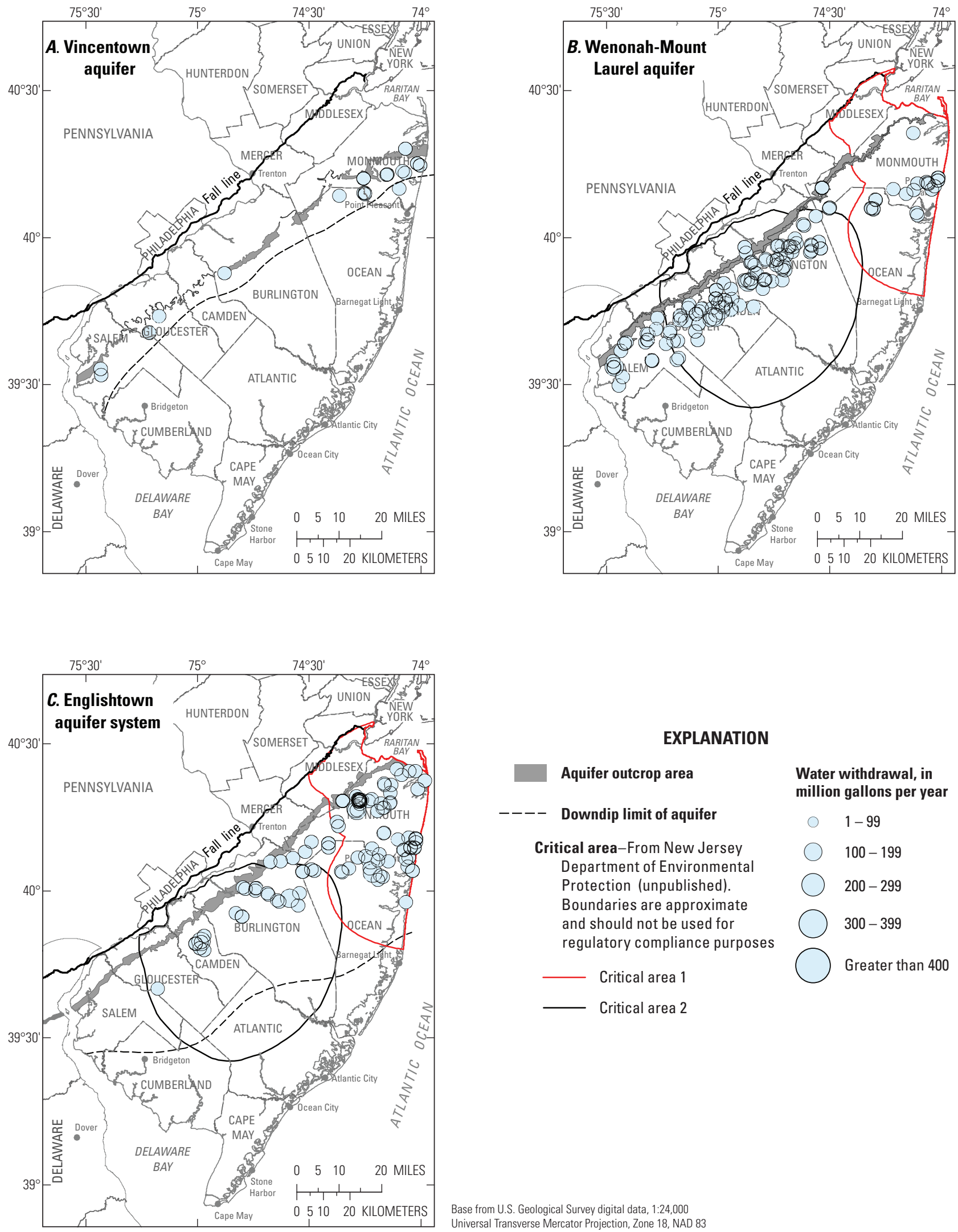

EXPLANATION

Aquifer outcrop area

Downdip limit of aquifer

Critical area-From New Jersey

Department of Environmental

Protection (unpublished).

Boundaries are approximate

and should not be used for

regulatory compliance purposes

Critical area 1

Critical area 2
Water withdrawal, in million gallons per year

- $\quad 1-99$

100-199

200-299

$300-399$

Greater than 400

Base from U.S. Geological Survey digital data, 1:24,000

Universal Transverse Mercator Projection, Zone 18, NAD 83

Figure 13. Location and volume of groundwater withdrawals from $A$, the Vincentown aquifer, $B$, Wenonah-Mount Laurel aquifer, and $C$, the Englishtown aquifer system, New Jersey Coastal Plain, 2008. 


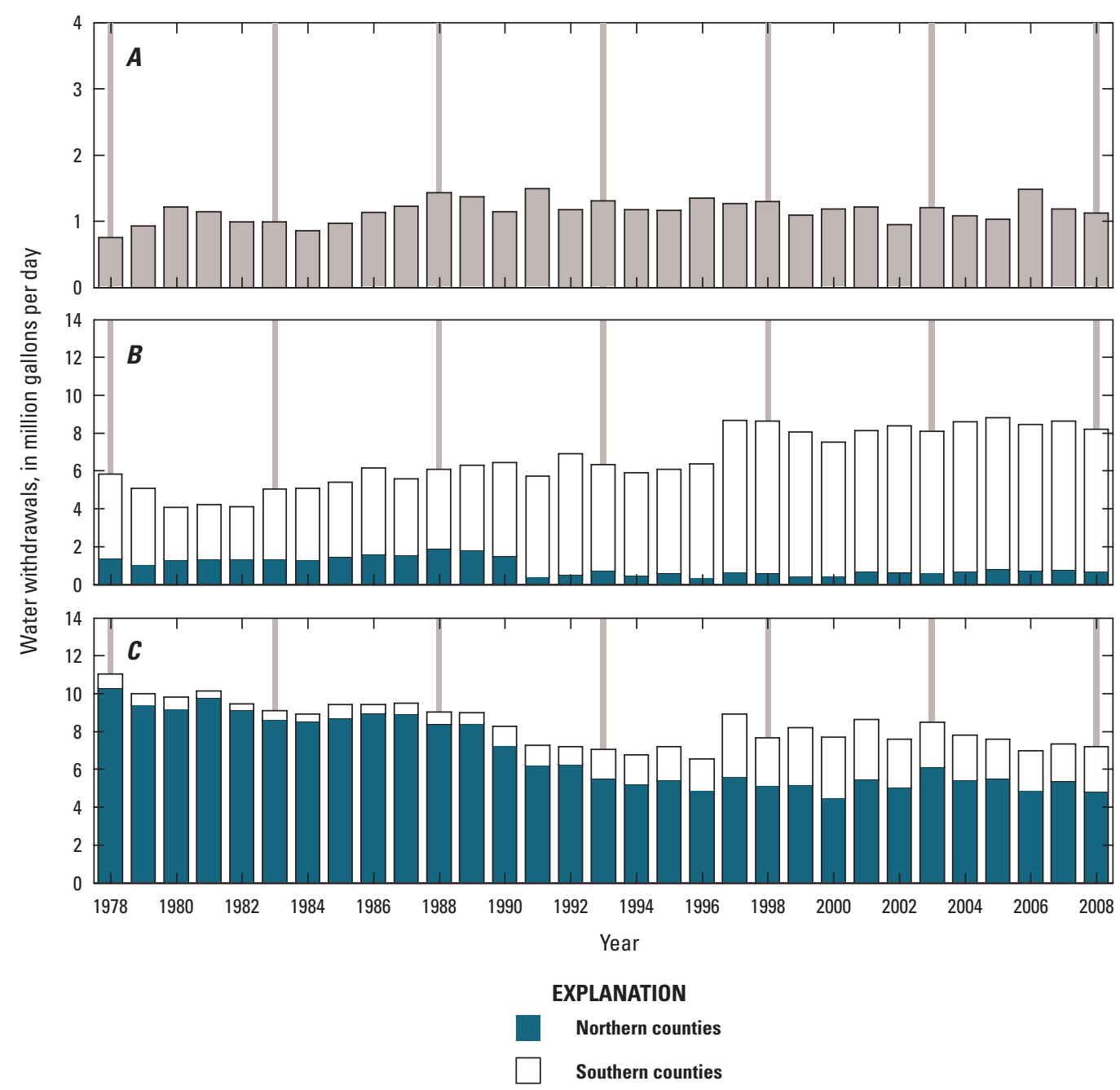

Figure 14. Estimated groundwater withdrawals from $A$, the Vincentown aquifer, $B$, the Wenonah-Mount Laurel aquifer, and $C$, the Englishtown aquifer system, New Jersey Coastal Plain, 1978-2008. (Thin vertical bars denote 5-yr data collection periods; note different vertical scaling) 

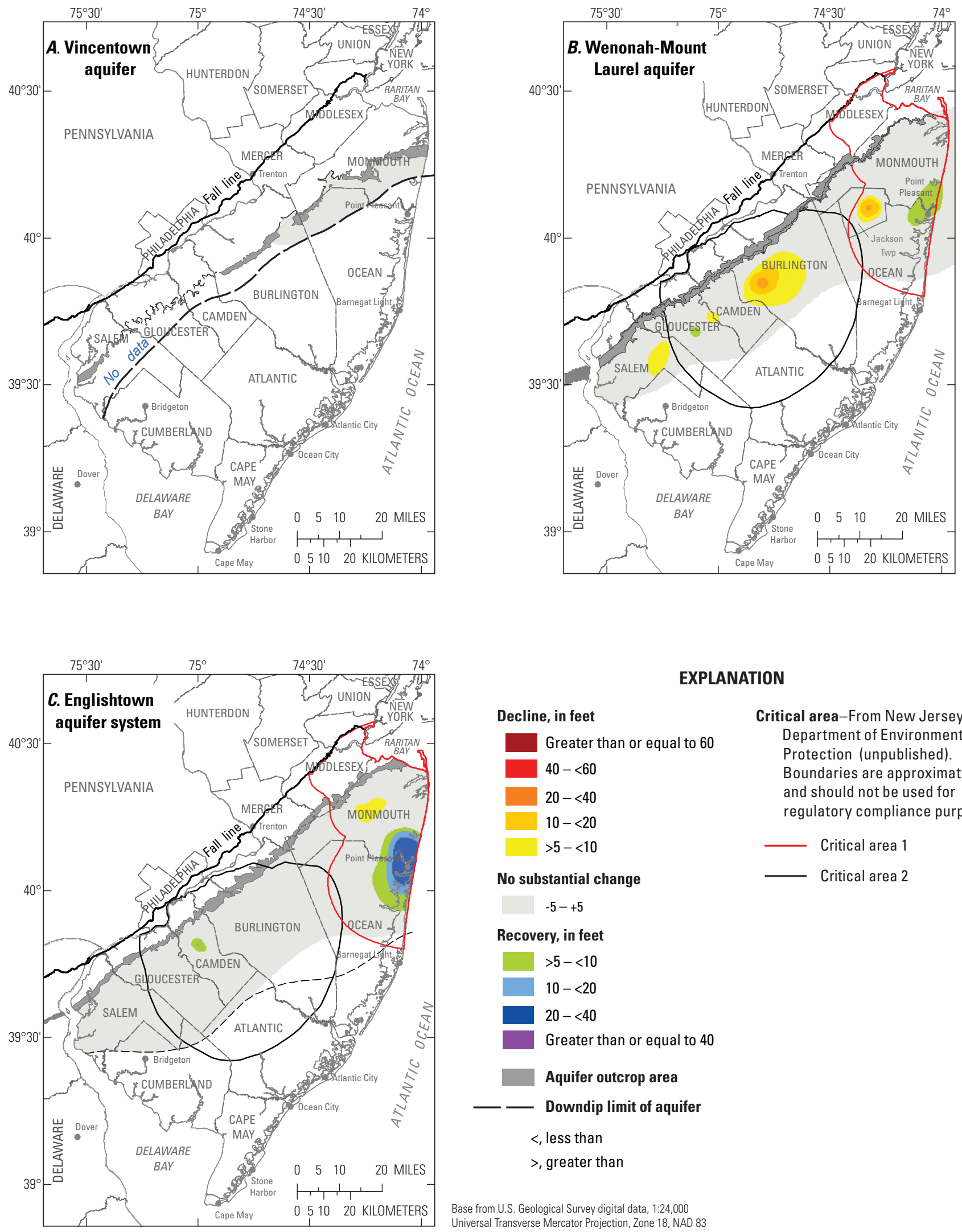

\section{EXPLANATION}

\section{Decline, in feet}

Greater than or equal to 60

$40-<60$

$20-<40$

$10-<20$

$>5-<10$

No substantial change

$-5-+5$

\section{Recovery, in feet}

$>5-<10$

$10-<20$

$20-<40$

Greater than or equal to 40

Aquifer outcrop area

—— Downdip limit of aquifer

$<$, less than

$>$, greater than
Critical area-From New Jersey Department of Environmental Protection (unpublished). Boundaries are approximate and should not be used for regulatory compliance purposes

\section{Critical area 1}

Critical area 2

Figure 15. Groundwater level changes in $A$, the Vincentown aquifer, $B$, the Wenonah-Mount Laurel aquifer, and $C$, the Englishtown aquifer system, New Jersey Coastal Plain, 2003-8. 


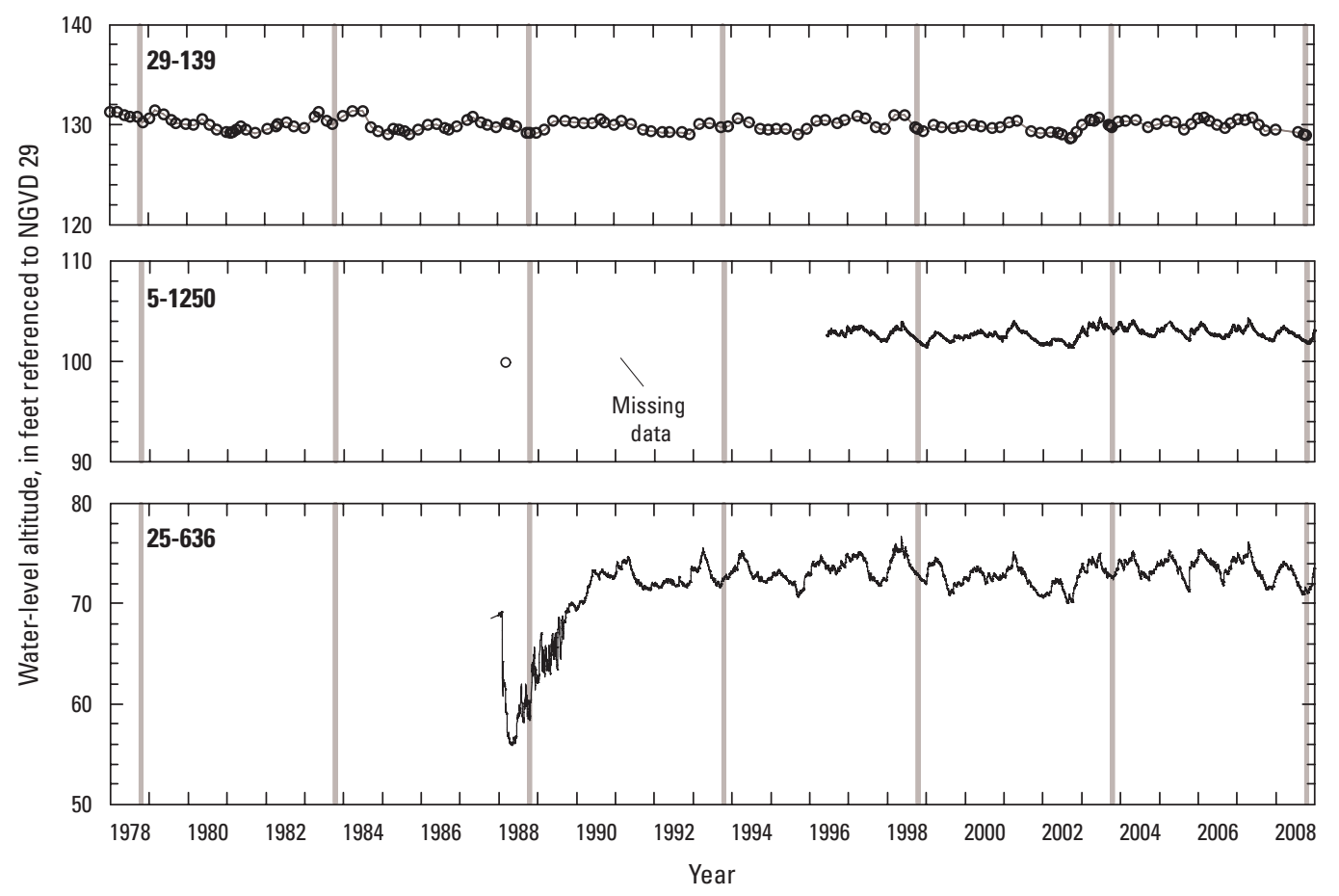

EXPLANATION

Water-level measurement

- Continuous

- o Manual

Figure 16. Water-level hydrographs for selected observation wells screened in the Vincentown aquifer, New Jersey Coastal Plain, 1978-2008. (All hydrographs are at the same scale; vertical bars denote 5-yr data collection cycles; well locations shown on pl. 4)

\section{Wenonah-Mount Laurel Aquifer}

The Wenonah-Mount Laurel aquifer is composed of the sand of the Mount Laurel Formation and, locally, the upper part of the Wenonah Formation where the latter is not composed predominantly of silt. The Mount Laurel Formation is a slightly glauconitic, micaceous quartz sand; shell beds are fairly common throughout. The upper part of the Wenonah Formation consists of slightly glauconitic, clayey fine sand or silt containing abundant lignite fragments and occasional pyrite (Owens and others, 1970); at its base, the formation grades to a silt. The aquifer crops out within the exposures of the Mount Laurel and Wenonah Formations from Monmouth and Middlesex Counties in the northeastern part of the Coastal Plain to Salem County in the southwest (pl. 5). The downdip limit of the aquifer is offshore of Monmouth and Ocean Counties; in the southern New Jersey counties-Atlantic, Cumberland, and Cape May - this limit is poorly defined. The productivity at any location is based on the thickness and silt content of the materials composing the aquifer. The aquifer is thickest in southwestern New Jersey (western Salem, and central Gloucester and Camden Counties) where it is most often used for water supply. In this area, thicknesses of $100 \mathrm{ft}$ to $200 \mathrm{ft}$ are common (Zapecza, 1989). In Salem County, the silt content increases, and the productive sands decrease accordingly. In the northeastern part of the Coastal Plain, the aquifer is used for water supply in central and eastern Monmouth and northern Ocean Counties; the aquifer here is generally $60 \mathrm{ft}$ to $80 \mathrm{ft}$ thick (Zapecza, 1989), although thicknesses may exceed $100 \mathrm{ft}$ in some areas of Monmouth County.

The Wenonah-Mount Laurel aquifer contains freshwater throughout much of its confined extent. In the northern part of the study area, chloride concentrations in groundwater generally range from 2 to $20 \mathrm{mg} / \mathrm{L}$ with concentrations increasing in the downdip direction. The highest chloride concentrations along the coast in Monmouth County typically were less than $25 \mathrm{mg} / \mathrm{L}$. Occasional elevated concentrations were observed in close proximity to outcrop areas where recently recharged groundwater may discharge to pumped wells finished in the confined aquifer. In southern Cumberland and Salem Counties, a zone of saline groundwater is present along the Delaware estuary, extending approximately $2 \mathrm{mi}$ inland in the southwestern part of Salem County (pl. 5). Elevated chloride concentrations ( 50 to greater than $100 \mathrm{mg} / \mathrm{L}$ ) also are present in 
groundwater in and near the city of Salem. During 1990-2004, chloride concentrations in some supply wells increased to more than $150 \mathrm{mg} / \mathrm{L}$, with the greatest annual rates of increase occurring during 2000-2. Concentrations have since stabilized at approximately $100 \mathrm{mg} / \mathrm{L}$. Elsewhere in southern New Jersey, in areas where the aquifer is used, the groundwater is generally fresh, and chloride concentrations are typically less than $25 \mathrm{mg} / \mathrm{L}$.

\section{Water Withdrawals}

Groundwater withdrawals from the Wenonah-Mount Laurel aquifer occur mostly in southern New Jersey where the aquifer is confined throughout a narrow band from central Burlington County to central Salem County from the outcrop to less than $10 \mathrm{mi}$ downdip (fig. 13). Groundwater is also withdrawn in eastern Monmouth County, along and within $10 \mathrm{mi}$ of the Atlantic coast. From 1978 to 2008, withdrawals ranged from 4.1 to $8.8 \mathrm{Mgal} / \mathrm{d}$; in 2008, withdrawals averaged $8.2 \mathrm{Mgal} / \mathrm{d}$ (fig. $14 \mathrm{~B}$, table 3). During 2008, most of the groundwater $(7.5 \mathrm{Mgal} / \mathrm{d}, 91$ percent) was pumped from the aquifer underlying the southern counties of New Jersey and, during most years, was typically greater by an order of magnitude than that pumped in the north. Withdrawals in the northern counties decreased from about $1.4 \mathrm{Mgal} / \mathrm{d}$ in 1978 to $0.7 \mathrm{Mgal} / \mathrm{d}$ in 1993 with the largest reduction occurring in 1991 as a result of the implementation of Critical Area 1 cutbacks. During the same period, groundwater withdrawals in the southern counties increased only marginally; thereafter, withdrawals increased to more than $8 \mathrm{Mgal} / \mathrm{d}$ with peak volumes occurring during 1997-98 and 2005 (fig. 14B). From 1996 to 1997, average withdrawals from the aquifer in southern counties increased by 34 percent in an effort to supplement lost allocation from the regulated PRM aquifers in Critical Area 2.

\section{Water Levels}

The potentiometric surface map, depicting water levels during the fall and early winter 2008 for the Wenonah-Mount Laurel aquifer, is shown in plate 5; supporting water-level data used to construct this map are presented in appendix 5. The 2008 potentiometric surface shows high groundwater altitudes near the outcrop in northern New Jersey Coastal Plain counties, a potentiometric low near the outcrop in north-central Burlington County, and three cones of depression within the aquifer. The highest groundwater altitudes were observed near the outcrop in Monmouth County (147 ft in well 25-412); the lowest were observed in coastal Monmouth County and along the border of central Camden and Gloucester Counties. The northernmost cone of depression, located in the coastal region of Monmouth and Ocean Counties, is elongate in shape; is centered beneath the boroughs of Point Pleasant, Brielle, and Spring Lake Heights; and extends throughout a broad area from Seaside Park in northern Ocean County north to Long
Branch in Monmouth County and west toward Lakewood. The configuration and shape of the cone of depression is similar to that in the underlying Englishtown aquifer system, though the generally lower transmissivity of the aquifer produces a cone that is narrower. Simulated contours (Voronin, 2004) were used to guide the closure of contours at the eastern or offshore edge of the cone. At the deepest part of the cone, groundwaterlevel altitudes ranged from -63 to $-68 \mathrm{ft}$, a rise of 6 to $8 \mathrm{ft}$ from levels observed in 2003 . Within the area encompassed by the $0-\mathrm{ft}$ contour, groundwater withdrawals from the aquifer in 2008 were estimated to be approximately $0.4 \mathrm{Mgal} / \mathrm{d}$. Given the depth and breadth of this cone, this amount is not substantial; the relatively low transmissivity of the aquifer of 500 to 700 square feet per day ( $\left.\mathrm{ft}^{2} / \mathrm{d}\right)$ (Martin, 1998), coupled with long-term withdrawals and low potentiometric head in the underlying Englishtown aquifer system, contribute to the size and persistence of the cone.

The central cone of depression, the smallest of the three, is centered beneath the community of Browns Mills and has a minimum water-level altitude of -27 ft (well 5-367). Average groundwater withdrawals during 2008 from 10 wells in the Browns Mills area were modest at $0.54 \mathrm{Mgal} / \mathrm{d}$. Since 1980, average withdrawals ranged from 0.5 to $1.2 \mathrm{Mgal} / \mathrm{d}$, peaking in the early 1990s and generally decreasing thereafter. Notable reductions in withdrawals of more than 15 percent from the previous year occurred in 1994, 1996, and 2006.

The southern cone of depression underlies parts of central Burlington, Camden, and Gloucester Counties. This elongated cone of depression began to form after 1983. Two smaller cones of depression have since merged to form the larger, more regionally extensive feature present in 2008, extending approximately $30 \mathrm{mi}$ along the direction of the strike of the Wenonah and Mount Laurel Formations. The northernmost "center" of the cone underlying Medford Lakes has a potentiometric-surface low of -55 ft (well 5-1253), a decline of more than $20 \mathrm{ft}$ from the previous study. The southernmost "center" underlies an area straddling the border between Camden and Gloucester Counties; its length is approximately $8 \mathrm{mi}$ along the direction of strike. The low water level of $-82 \mathrm{ft}$ (well 7-847) represents a decline of $11 \mathrm{ft}$ from 2003. Each center is characterized by steep, lateral hydraulic gradients in their respective updip areas, ranging from 42 to $50 \mathrm{ft} / \mathrm{mi}$.

Vertical head differences between the Piney Point and the Wenonah-Mount Laurel aquifers indicate a moderate to strong downward gradients in central Burlington, Camden, and Gloucester Counties, particularly in areas where the WenonahMount Laurel aquifer is experiencing pumping stresses, such as Winslow and Monroe Townships (Williamstown quadrangle). Potentiometric differences range from 60 to $80 \mathrm{ft}$ in this area, with maximum differences exceeding $100 \mathrm{ft}$. Throughout much of the mid-dip and updip areas of the aquifer, a downward hydraulic gradient is present from the Wenonah-Mount Laurel aquifer to the underlying Englishtown aquifer system. At the deep cone of depression in the Wenonah-Mount Laurel aquifer in coastal Ocean and Monmouth Counties, water-level differences between the two units can be substantial, although 
along the eastern and northern edges, these differences moderate and, in places, are neutral.

Groundwater-level changes in the Wenonah-Mount Laurel aquifer from 2003 to 2008 are shown in figure $15 B$. Most groundwater levels measured showed small to moderate changes relative to 2003, although large declines were indicated in a few areas. Water levels declined in 84 wells (74 percent), recovered in 21 wells (19 percent), and remained about the same in 8 wells ( 7 percent). Water levels, in general, rose 5 to $10 \mathrm{ft}$ near the center of the regional cone of depression underlying eastern Monmouth County (fig. 15B), continuing the long-term trend of recovery in this area. This rise in water-levels can be attributed to a reduction in withdrawals and corresponding recovery in the underlying Englishtown aquifer system, as the volume of, and year to year changes in, withdrawals from the Wenonah-Mount Laurel are minor. Away from the center of the cone of depression, changes in groundwater levels were subtle, and declines or rises of 2 to 3 feet were most common. Beyond the 0 - $\mathrm{ft}$ contour and to the north and west, the potentiometric surface showed little to no change from 2003. In central Jackson Township, however, water levels were as much as $20 \mathrm{ft}$ lower than in 2003 despite modest increases in withdrawals of less than 10 percent.

Throughout the southern counties, water levels measured in 2003 and 2008 declined in 66 percent of wells, recovered in 10 percent, and remained about the same in 24 percent. Within the Browns Mills cone of depression, water levels remained about the same as in 2003, reflecting stable trends in withdrawals. Groundwater levels in central Burlington County declined from 2 to $23 \mathrm{ft}$ in response to increasing withdrawals in the vicinity of Medford Lakes. In comparison, water-level declines near the Camden/Gloucester County line were more moderate, and stable to rising water levels were observed in surrounding municipalities, reflecting an 11 percent decrease in withdrawals since 2003.
Results of the Wilcoxon signed-rank test indicate a statistically significant difference (decline) in paired waterlevel measurements in the dataset as a whole (app. 10-2) from 2003 to 2008. A similar relation was observed in measurements throughout Critical Area 2; however, no significant difference among compared measurements throughout Critical Area 1 was indicated. Significant decreases between paired measurements were observed for Burlington, Camden, Ocean, and Salem Counties, but not for Monmouth or Gloucester Counties. From 1998 to 2008, significant differences between paired measurements were not observed.

Results of the Mann-Kendall statistical trend test are listed in appendix 10-1. Supporting hydrographs for eight observation wells that show long-term and seasonal trends in the Wenonah-Mount Laurel aquifer from 1978 to 2008 are provided in figures 17 and 18. From 2003 to 2008, statistically significant downward trends were observed for 5 wells (7-118, 7-478, 29-140, 33-20, and 33-252), and upward trends were observed for 2 wells (25-486 and 25-637). Downward trends were strongest for wells 7-478 and 33-20 and weakest for wells nearest the outcrop (33-252 and 7-118). No significant upward or downward trend was observed for well 25-353. From 1998 to 2008, significant downward trends were observed for two wells, 7-478 and 29-140. Observation well 7-478 is located near the border between Camden and Gloucester Counties and along the downdip side of the southern cone of depression. Following a $70-\mathrm{ft}$ water-level decline over an 18-year period (1983-2001), water levels stabilized, then rose during 2004-5, but have since declined. Well 29-140, located in the mid-dip section of the aquifer in northern Ocean County, shows only a modest decline for the 10 -year period, as well as for the period of record. Upward trends were observed for wells 25-353, 25-486, and 25-637 for their respective periods of record; in contrast, downward trends were observed for wells 7-478 and 33-20 from 1978 to 2008 .

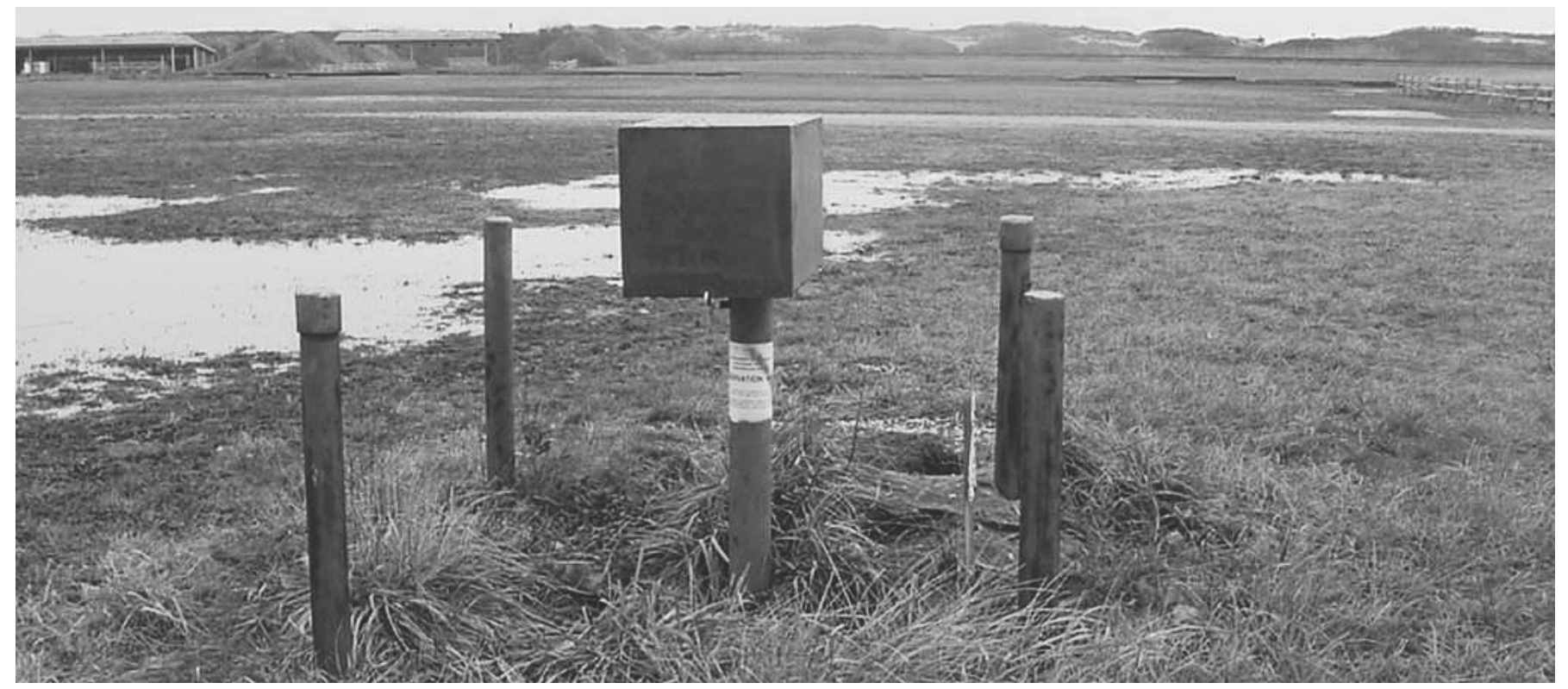

Photograph was provided by U.S. Geological Survey field personnel 


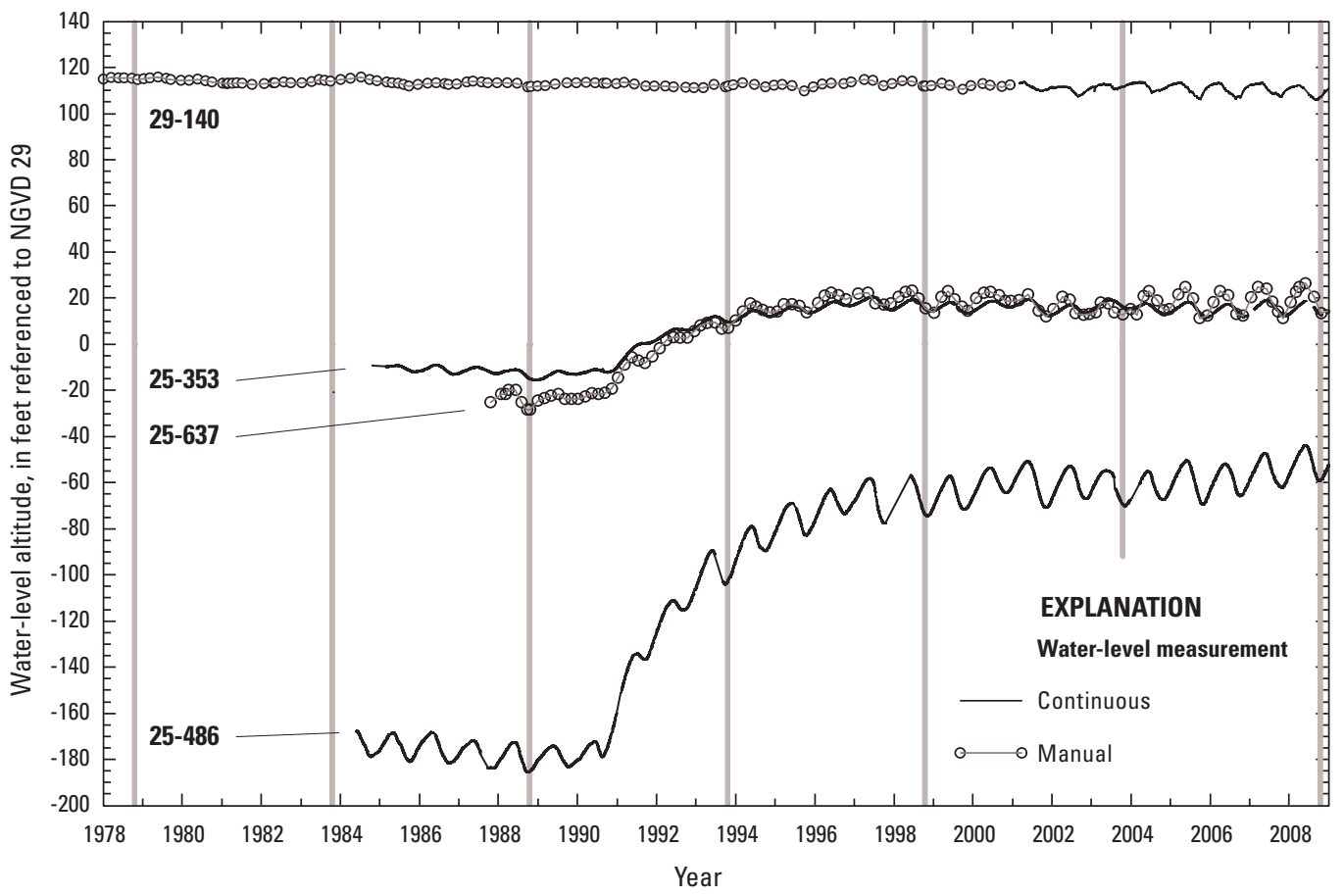

Figure 17. Water-level hydrographs for selected observation wells screened in the Wenonah-Mount Laurel aquifer in the northern counties of the New Jersey Coastal Plain, 1978-2008. (Vertical bars denote 5-yr data collection cycles; well locations shown on pl. 5)

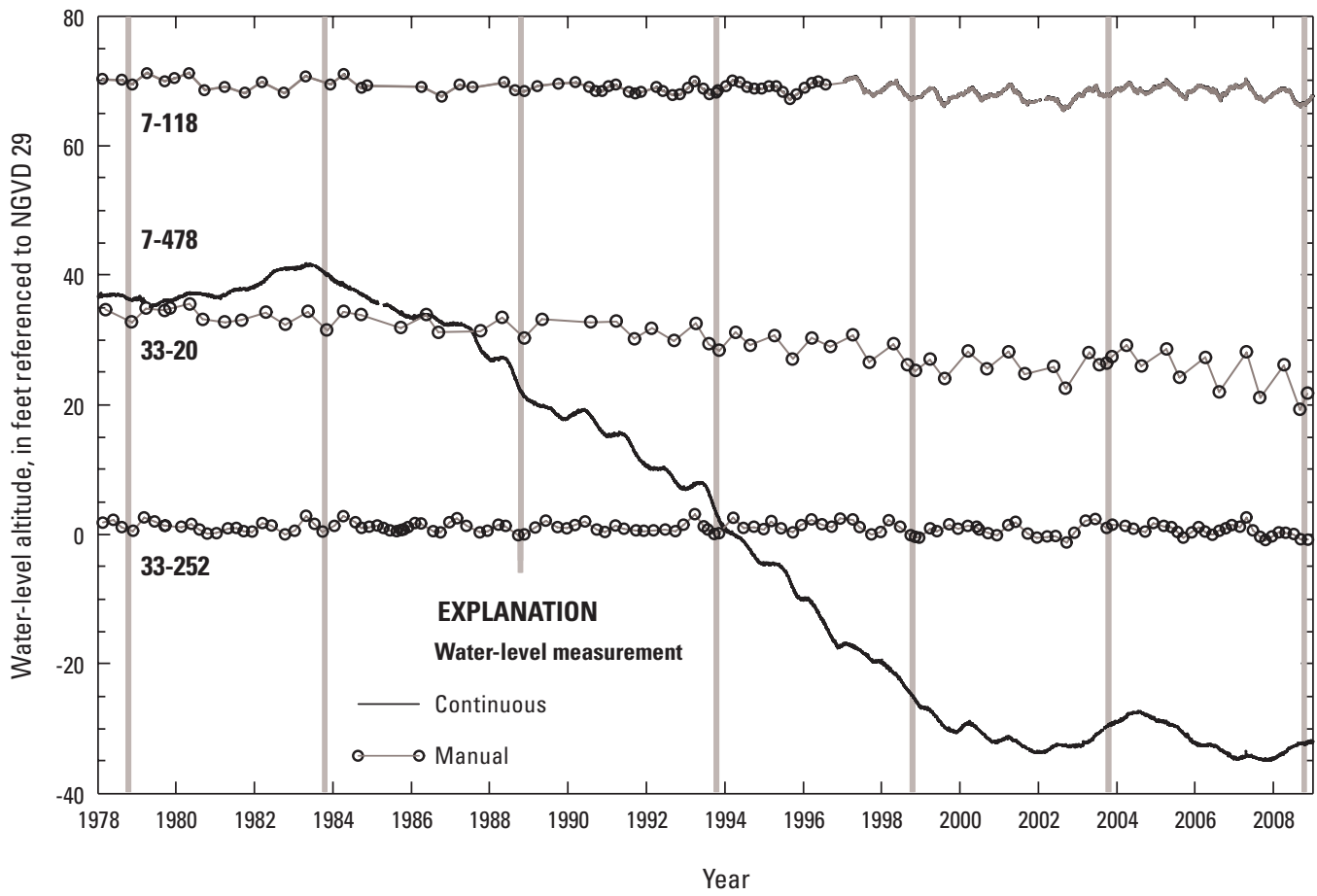

Figure 18. Water-level hydrographs for selected observation wells screened in the Wenonah-Mount Laurel aquifer in the southern counties of the New Jersey Coastal Plain, 1978-2008. (Vertical bars denote 5-yr data collection cycles; well locations shown on pl. 5) 


\section{Englishtown Aquifer System}

The Englishtown Formation is a fine- to medium-grained feldspathic quartzose sand that in some places grades to a silt. The formation is thickest ( $200 \mathrm{ft}$ ) in Monmouth County and remains sandy and thick a substantial distance downdip from the outcrop; therefore, the aquifer yields large quantities of water in Monmouth and Ocean County. In central and southern Ocean County, a confining unit partitions the Englishtown aquifer system into upper and lower aquifers. The aquifer system is underlain by the Merchantville-Woodbury confining unit, which is the most extensive confining unit in the Coastal Plain. The Englishtown Formation thins considerably to the southwest, where sandy units are discontinuous and silt beds predominate (Zapecza, 1989). The approximate downdip limit of the aquifer system is shown on plate 6; it extends from the Forked River in Ocean County, southwest through Hammonton and Buena in Atlantic County, then along an east-west trending line through Bridgeton in Cumberland County to the Delaware Estuary in Salem County. The distance from outcrop to the downdip boundary is approximately $34 \mathrm{mi}$ in Ocean County, but to the southwest, the lateral extent of the confined aquifer decreases to about $12 \mathrm{mi}$ in southern Salem County. To the south and east the aquifer is not recognized on geophysical logs that penetrate the section (Zapecza, 1989). Transmissivity in the Englishtown aquifer system decreases substantially to the southwest as geologic material composing the aquifer matrix becomes finer-grained (Nichols, 1977), and little water is produced from the aquifer in the southwestern part of the State (Zapecza, 1989).

Most of the confined part of the Englishtown aquifer system contains fresh groundwater, except in a limited area at and surrounding the Sandy Hook observation well (25-771) in northeastern Monmouth County where chloride concentrations exceed $15,000 \mathrm{mg} / \mathrm{L}$. The geochemical imprint on the groundwater from this well indicates a direct connection to, and mixing with, seawater. The saline water is present below a 5-ft-thick clay lens, however, and is effectively segregated from the upper part of the aquifer where the groundwater is fresh and used for potable supply.

In updip and mid-dip sections of the confined aquifer, calcium and bicarbonate are the predominant ionic species, and concentrations of chloride are low, ranging from 1 to less than $10 \mathrm{mg} / \mathrm{L}$, except in northern Monmouth County where concentrations at times exceed $10 \mathrm{mg} / \mathrm{L}$. In far downdip areas of northern Ocean County, sodium is the predominant cation, and the groundwater exhibits high sodium to chloride molar ratios, ranging from 5:1 to $100: 1$, evidence of substantial amounts of cation exchange. Concentrations of chloride in groundwater from the lower part of the confined aquifer in these areas occasionally exceeded $15 \mathrm{mg} / \mathrm{L}$ and have been observed to be as high as $40 \mathrm{mg} / \mathrm{L}$ but are most often less than the former. No evidence of upward trends has been observed.

Chloride concentrations in the Englishtown aquifer system in southern New Jersey generally ranged from less than 1 to $9 \mathrm{mg} / \mathrm{L}$ throughout the confined aquifer, although higher concentrations were observed within and near outcrop areas. Chloride concentrations showed no apparent increase with increasing distance in the downdip direction; however, most of the chloride data from the southern counties are from wells within $10 \mathrm{mi}$ of the outcrop. Water-quality data farther downdip are sparse, and substantive conclusions about the evolution of groundwater toward this boundary could not be made. Chloride data for individual wells through time also are rare, and temporal trends could not be determined.

\section{Water Withdrawals}

Withdrawals from the Englishtown aquifer system are made primarily in Monmouth and northern Ocean Counties and in central Camden County; however, smaller-capacity production wells are present throughout north-central Burlington County (fig. 13C). The aquifer is used locally in eastern Mercer County and near the outcrop in Salem and Gloucester Counties where withdrawals are made primarily for domestic self-supply. Average withdrawals from the Englishtown aquifer system in 2008 were approximately $7.2 \mathrm{Mgal} / \mathrm{d}$ (table 3); withdrawals from the northern counties accounted for 67 percent of this volume. Withdrawals decreased from approximately $11 \mathrm{Mgal} / \mathrm{d}$ in 1978 to less than $7 \mathrm{Mgal} / \mathrm{d}$ by 1996 (fig. 14C) as a result of mandated cutbacks in Critical Area 1 and, beginning in 1991, the use of the Manasquan Reservoir as an alternative source of water. Reductions during 1989-91 (26 percent) were the most notable. In 1997 withdrawals increased to nearly $9 \mathrm{Mgal} / \mathrm{d}$ and, during the ensuing decade, ranged from 7 to $8.5 \mathrm{Mgal} / \mathrm{d}$. In northern Coastal Plain counties, withdrawals averaged nearly $9 \mathrm{Mgal} / \mathrm{d}$ during the $1980 \mathrm{~s}, 5.7 \mathrm{Mgal} / \mathrm{d}$ during the $1990 \mathrm{~s}$, and from 2000 to 2008 , $5.2 \mathrm{Mgal} / \mathrm{d}$.

Withdrawals from the aquifer system in the southern counties were constant at approximately $0.5 \mathrm{Mgal} / \mathrm{d}$ from 1978 through 1987 (fig.14C); in 1988 withdrawals began to increase gradually. By 1996, average withdrawals were nearly $1.7 \mathrm{Mgal} / \mathrm{d}$; a sharp increase to $3.3 \mathrm{Mgal} / \mathrm{d}$ followed in 1997. In 1997 in Camden County, estimated withdrawals more than doubled from the previous year because of new wells brought on line in the county. This increase in the use of the Englishtown aquifer system was a consequence of restrictions placed on withdrawals from the underlying PRM aquifer system in 1996. From 1998 to 2001 withdrawals averaged approximately $3 \mathrm{Mgal} / \mathrm{d}$. In 2002, withdrawals from the aquifer system in the southern Coastal Plain began a gradual decline, then leveled at approximately $2 \mathrm{Mgal} / \mathrm{d}$. In 2008 average withdrawals throughout the southern Coastal Plain counties were $2.3 \mathrm{Mgal} / \mathrm{d}$.

\section{Water Levels}

The potentiometric surface during the fall and early winter of 2008 for the Englishtown aquifer system is shown on plate 6; supporting water-level data used to construct this map 
are presented in appendix 6 . The highest groundwater altitudes within the confined aquifer exceeded $100 \mathrm{ft}$ and occurred near the outcrop in western Monmouth County, roughly coinciding with areas of greatest topographic relief. The lowest groundwater altitudes (-84 to $-101 \mathrm{ft}$ ) occurred along the Monmouth/ Ocean County boundary and are associated with pumping centers near Point Pleasant and Lakewood. The dominant feature of the groundwater flow system is a prominent cone of depression underlying northeastern Ocean and eastern Monmouth Counties (pl. 6). This regionally extensive cone of depression has been well documented; a 1958 potentiometric surface map by Seaber (1965) shows water levels in this area in excess of $100 \mathrm{ft}$ below NGVD 29. Nichols (1977) similarly documents declines in water levels from 1900 to 1959 of greater than $100 \mathrm{ft}$ near the border of Monmouth and Ocean Counties; from 1959 to 1983, groundwater levels in this region declined an additional $150 \mathrm{ft}$.

The location and configuration of this cone is similar to that in the overlying Wenonah-Mount Laurel aquifer; vertical leakance through the confining unit allows good hydraulic connection between the two aquifers. Closed contours on the seaward side of the cone were mapped on the basis of simulations by Voronin (2004). The lateral hydraulic gradient on the updip side of the cone of depression is relatively steep, ranging from 12 to $30 \mathrm{ft} / \mathrm{mi}$; on the downdip side this gradient is generally less than $5 \mathrm{ft} / \mathrm{mi}$. The cone of depression is composed of several smaller cones underlying pumping centers located at Point Pleasant, Spring Lake, and Lakewood, the largest of which underlies coastal communities from Mantoloking in northern Ocean County to Belmar in southern Monmouth County. Lowest water-level altitudes in this area $(<-80 \mathrm{ft})$ were measured in production wells at Point Pleasant.

The remaining local cones underlie areas near the town of Lakewood. Each is radially small but deep, and each is associated with either a single well or two wells. This area is characterized by a potentiometric head of less than $-70 \mathrm{ft}$, with the minimum groundwater altitude $(-101 \mathrm{ft})$ observed in the northern part of the municipality, near the Metedeconk River.

A local depression in the potentiometric surface at Freehold (well 25-727) is indicated on the map (pl. 6) by the upswept 80-ft contour in the southeastern part of the Freehold quadrangle. This feature was initially included on the 1993 potentiometric map and verified during the 1998 and 2003 studies (Lacombe and Rosman, 2001; DePaul and others, 2009). A measured water-level altitude near this feature was $62 \mathrm{ft}$, a decline from the previous study of $6 \mathrm{ft}$. In the southern counties, groundwater altitudes ranged from a high of $96 \mathrm{ft}$ in northern Burlington County to a low of $-38 \mathrm{ft}$ where a small, localized cone of depression is present in central Burlington County beneath the community of Browns Mills.

Vertical head differences between the Englishtown aquifer system and the Upper PRM aquifer are significant in updip and mid-dip areas of western Monmouth, northeastern Ocean, and Camden Counties. Groundwater altitudes during 2008 in the Englishtown aquifer system were as much as 117, 115, and $104 \mathrm{ft}$ higher in Monmouth, Ocean, and Camden Counties, respectively, and the potential for downward flow out of the Englishtown aquifer system is greatest in these areas. In eastern Monmouth and northeastern Ocean County, however, groundwater altitudes are higher in the Upper PRM aquifer than in the Englishtown aquifer system. Despite heads that are more than $40 \mathrm{ft}$ higher in the Upper PRM aquifer than in the Englishtown aquifer system beneath the cone of depression in eastern Monmouth and Ocean Counties, upward flow is impeded owing to the thickness and low permeability of the underlying Merchantville-Woodbury confining unit in that area (Martin, 1998).

Water-level differences between the Englishtown aquifer system and the Wenonah-Mount Laurel aquifer are generally less than those between the Upper PRM aquifer and the Englishtown aquifer system. Water-level differences range from 10 to $25 \mathrm{ft}$ in updip areas of Monmouth and Ocean County; however, in mid-dip areas where the Englishtown aquifer system is used for supply, water levels may be as much as $45 \mathrm{ft}$ lower than those in the overlying Wenonah-Mount Laurel aquifer. Along the western edge of the cone of depression in coastal Monmouth and Ocean Counties, water-level differences are as much as $60 \mathrm{ft}$, and the Englishtown aquifer system receives downward recharge from the overlying Wenonah-Mount Laurel aquifer, contributing to the sustained potentiometric lows in the Wenonah-Mount Laurel aquifer. Flow from the Wenonah-Mount Laurel aquifer to the Englishtown aquifer system may be substantial in areas where vertical gradients are strong because of the relatively high leakance of the Marshalltown-Wenonah confining unit (Martin, 1998). Water-level differences decrease toward the east and north of the cone of depression, ranging from 5 to $20 \mathrm{ft}$.

Water-level changes from 2003 to 2008 were calculated for the 76 wells open to the Englishtown aquifer system and measured in both years. A map showing these water-level changes is provided in figure $15 \mathrm{C}$. Of the wells measured in both 2003 and 2008, water levels declined in 40 (53 percent), recovered in 32 (42 percent), and remained the same in 4 (5 percent). Water-level declines ranged from 1 to $23 \mathrm{ft}$ and were most common in central Monmouth County to the north and updip from the regional cone of depression, and in updip and mid-dip areas of northwestern Ocean and Burlington Counties. In mid-dip areas of north-central Ocean County, groundwater levels did not change. The largest changes were observed at and near the center of the regional cone of depression where a 40-percent reduction in withdrawals relative to 2003 volumes caused water levels to recover by 28 to $38 \mathrm{ft}$. On the western and updip side of the cone of depression, water levels were stable or had recovered by 3 to $18 \mathrm{ft}$. At the southern edge of the cone of depression, water levels were unchanged or modestly recovered.

In central Camden County in southern New Jersey, water levels were as much as $20 \mathrm{ft}$ higher than those observed in 2003. Rising water levels occurred throughout several small municipalities as a result of a 20 -percent reduction in withdrawals during this period.

Results of the Wilcoxon signed-rank test indicate that, from 2003 to 2008 and from 1998 to 2008, the differences in 
paired water-level measurements throughout the aquifer were not significant (appendix 10-2). In Critical Area 1, water levels recovered during 1998-2008 and 2003-8, although during 2003-8, rises are not statistically significant at the 95-percent confidence level. Evaluated by county, water-level rises from 2003 to 2008 in Ocean County were significant, and declines in Burlington County were significant during the same period. There were no significant changes in other counties during 2003-8 and no significant changes in any county during 1998-2008.

Results of the Mann-Kendall statistical trend test are listed in appendix 10-1. Supporting hydrographs for nine observation wells that graphically depict long-term and seasonal trends in the Englishtown aquifer system from 1978 to 2008 are shown in figure 19. The hydrographs for wells 23-104 and 25-715 show little to no change in water levels during the periods of record, whereas the hydrograph for well 29-138 shows periods of modest decline and subsequent recovery. Wells 23-104 and 25-715 are located in updip areas, and well 29-138 is within the mid-dip section of the aquifer system. These wells are distant from the regional cone of depression along the coast.

The water level in well 25-715, located near Sandy Hook Bay in northern Monmouth County, has remained relatively constant since the well was installed in 1991. Withdrawals from the aquifer are made $1.25 \mathrm{mi}$ to the west but are minor; therefore, the range in seasonal fluctuations is small, from 2 to less than $4 \mathrm{ft}$, and the long-term water-level change is barely perceptible. Temporal fluctuations observed in well 23-104 show responses to changes in precipitation and subsequent recharge; this well is located away from the influence of pumping wells and within the outcrop where infiltration is rapid and recharge paths are relatively short. From 1978 to 2008 , the water level in this well has remained essentially unchanged. Results of trend testing indicated a near-zero slope for the periods of record (1978-2008) at both wells.

The hydrograph for well 29-138 (fig. 19) shows a gradual decline of $7 \mathrm{ft}$ during 1978-93, followed by a rise of $8 \mathrm{ft}$ through 1998; thereafter, annual high-water levels generally stabilized at $66 \mathrm{ft}$. During the latter part of the period of record, a slight downward trend was observed, and the water level declined by nearly $4 \mathrm{ft}$ from 2003 to 2008 .

Observation wells 25-250 and 5-259 are located in updip areas of western Monmouth and Burlington Counties, respectively, far from major cones of depression but near areas where the aquifer is pumped. From 2003 to 2008 a slight, downward trend was observed at well 5-259. A calculated slope of -0.46 indicates a water-level decline of 2 to $3 \mathrm{ft}$ during this period. In comparison, the trend observed at well 25-250 was statistically insignificant. For the 10 -year period, however, a slight upward trend was observed in well 25-250, and for the 30-year period, the trend, though insubstantial, was slightly downward.

Water-level change within the aquifer was more dynamic at wells located nearer the regional cone of depression. Well 29-530 is located near the center of the cone, and proceeding updip, in order of increasing distance, are wells 25-429 and 25-638. Water-level trends observed in each of the wells parallel one another, and with increasing distance inland, the slopes of the hydrographs become shallower, groundwater altitudes increase, and the seasonal variability is tempered. Owing to Critical Area conservation strategies introduced in the late 1980s, water levels rose sharply in all three wells from 1990 to 1996; the magnitude of recovery during this period was greatest in well 29-530 at approximately $100 \mathrm{ft}$. From 1998 to 2008, despite a brief decline during 2001-3, an upward trend in water levels occurred for wells 25-429 and 29-530. From 1998 to 2008, results of the Mann Kendall trend test indicate that no change occurred in the water levels in well 25-638; however, for the 5-year period 2003 to 2008, an upward trend is indicated. Both graphical and statistical analyses of data from well 29-534 indicate a trend similar to those in wells described above; however, the position of the well on the southern edge of the depression, distant from withdrawal centers, and the depth of its screened interval contribute to the moderation in both decline and recovery. Water levels in this well lack seasonality, and the inflection point indicating recovery lagged others by nearly 3 years. Results of the Mann Kendall trend test indicate significant upward trends for the 5-, 10-, and 30-year periods.

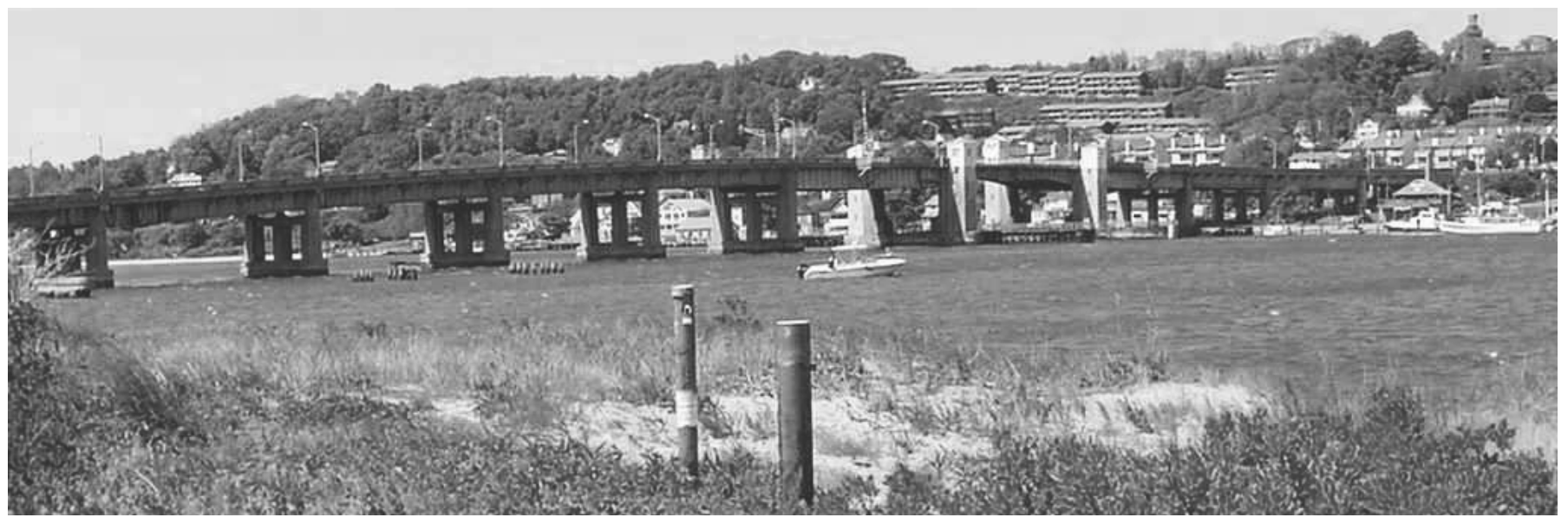

Photograph was provided by U.S. Geological Survey field personnel 


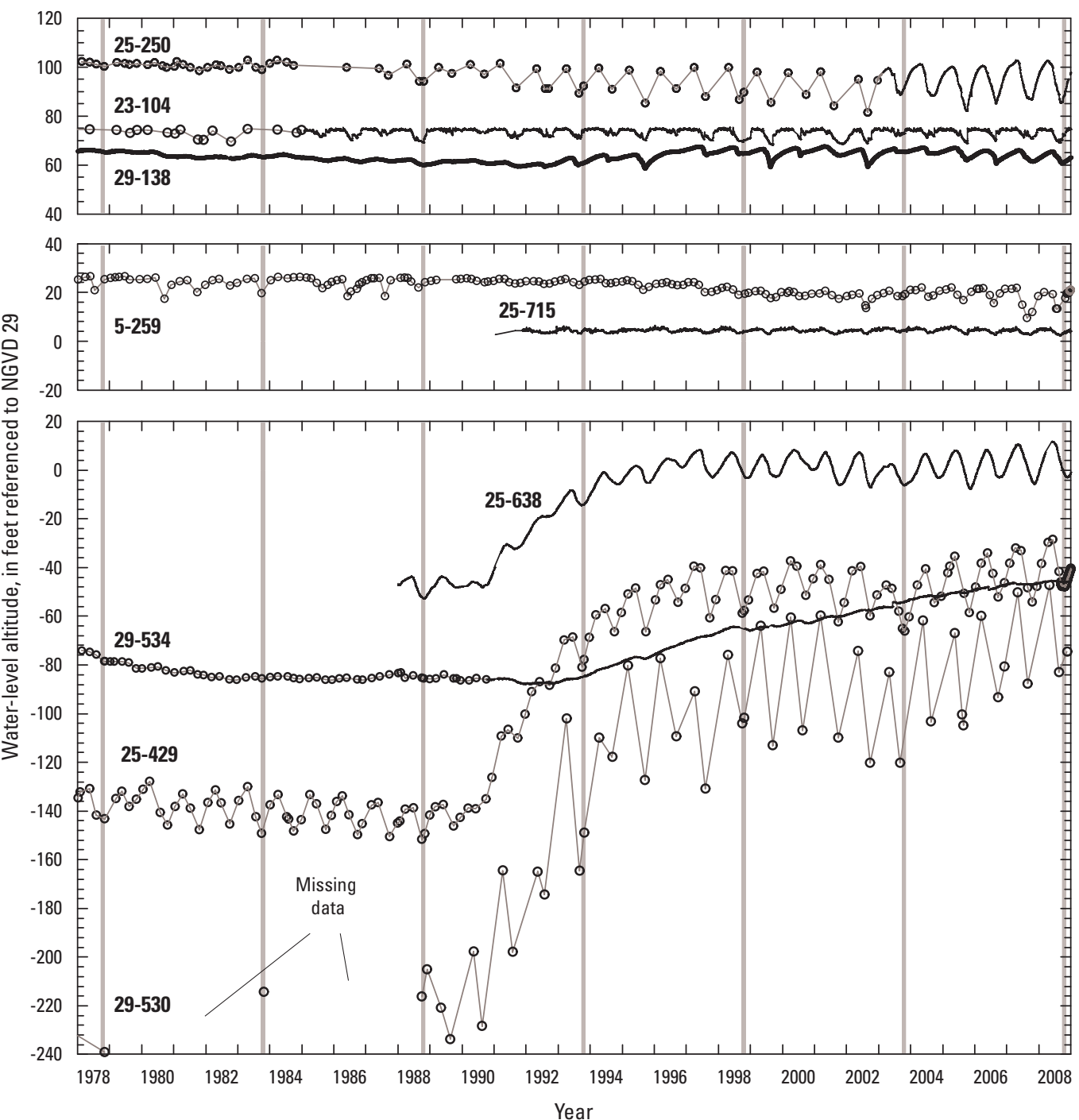

EXPLANATION

Water-level measurement

Continuous

- o Manual

Figure 19. Water-level hydrographs for selected observation wells screened in the Englishtown aquifer system, New Jersey Coastal Plain, 1978-2008. (Hydrographs are at the same scale; vertical bars denote 5-yr data collection cycles; well locations shown on pl. 6) 


\section{Potomac-Raritan-Magothy Aquifer System}

The PRM aquifer system includes the most productive aquifers in the New Jersey Coastal Plain. In order of increasing depth they are the Upper, Middle, and Lower PRM aquifers. The Upper PRM aquifer generally corresponds to the Magothy Formation in New Jersey (Zapecza, 1989) and is the most extensive unit within the aquifer system. In Monmouth and Middlesex Counties, the aquifer is locally referred to as the Old Bridge aquifer. The aquifer consists of coarse-grained permeable sands with thin interbedded clay and clayey silt layers present locally. The outcrop extends in a northeast to southwest trending band from the Raritan Bay to the Delaware River adjacent to Salem County and is mostly coincident with the outcrop of the Magothy Formation. The downdip part of the aquifer is well defined offshore of Monmouth and Ocean Counties but less well defined in Atlantic, Cumberland, and Cape May Counties. The thickness of the sand interval ranges from more than $200 \mathrm{ft}$ in eastern Monmouth County to about $50 \mathrm{ft}$ in Cape May County. Recharge to the aquifer is mainly from outcrop areas in Mercer, Middlesex, and Monmouth Counties and from the overlying Englishtown aquifer system, but water also enters the system from outcrop areas in Burlington, Camden, and Gloucester Counties because long-term withdrawals and cones of depression in these areas have altered the natural flow paths, converting areas formerly receiving discharge into recharge areas. The overlying confining unit, ranging in thickness from 200 to $300 \mathrm{ft}$ throughout Monmouth, Ocean, and southern Burlington Counties, is relatively impermeable and effectively impedes vertical flow in downdip areas (Zapecza, 1989). Transmissivity of the aquifer is greatest in the eastern part of Monmouth County, although the sand bodies remain highly conductive throughout western Monmouth County, as well as in western Camden and Gloucester Counties.

The Middle and undifferentiated aquifer of the PRM aquifer system extends from the Raritan Bay in the northeastern part of the study area to Maryland in the southwest. Northeast of Burlington County, the aquifer is locally referred to as the Farrington aquifer. The aquifer in this area is well defined from the outcrop area to about $20 \mathrm{mi}$ downdip; beyond this distance the aquifer cannot be separated from the underlying sediments within the PRM aquifer system. Zapecza (1989) refers to the aquifer in eastern Middlesex County and western Monmouth County as the undifferentiated PRM aquifer. Similarly, in southern New Jersey the aquifer can be traced in the subsurface from the outcrop to an area extending approximately $10 \mathrm{mi}$ to $12 \mathrm{mi}$ downdip, beyond which the aquifer is indistinguishable from the Lower PRM aquifer. Where the confining unit between the Lower and Middle aquifers is absent, the aquifer unconformably overlies bedrock or weathered bedrock. The transmissivity of the aquifer is greatest in northern Ocean County (greater than 16,000 ft' $/$ d), but the aquifer is most productive in Burlington, Camden, and
Gloucester Counties in, and within a short distance from, the outcrop area where the transmissivity ranges from $6,000 \mathrm{ft}^{2} / \mathrm{d}$ to more than 10,000 $\mathrm{ft}^{2} / \mathrm{d}$ (Martin, 1998). To the southwest, discontinuous silt and clay beds within the Middle aquifer in Salem County inhibit its productivity. The Middle PRM aquifer is continuous into Delaware where it is composed of the sandy parts within the upper part of the Potomac Formation. The updip limit of the aquifer in Delaware is within the outcrop of the Potomac Formation in northern New Castle County. The downdip limit of the freshwater-saltwater interface, as indicated by the $10,000 \mathrm{mg} / \mathrm{L}$ isochlor, extends into eastern Sussex County, Delaware.

The Lower PRM aquifer is the lowermost aquifer within the Coastal Plain of New Jersey and Delaware. The aquifer does not crop out in New Jersey but is entirely overlain by the confining bed separating the Middle and the Lower PRM aquifers. The aquifer is recognizable about 8 to $12 \mathrm{mi}$ downdip from the outcrop area of the Potomac and Raritan Formations (Zapecza, 1989); beyond this limit the aquifer cannot be differentiated from the overlying sediments of the Middle PRM aquifer. The transmissivity of the aquifer is highest in northwestern and central Camden County and adjoining areas in Gloucester and Burlington Counties; this is where the aquifer is most productive. The Lower PRM is continuous into Delaware, coinciding with the lower part of the Potomac Formation. The updip limit of the aquifer in Delaware lies between the western edge of the Coastal Plain sediments and the updip limit of the Middle PRM aquifer; the downdip limit is in northern Kent County (Vroblesky and Fleck, 1991).

\section{Extent of Saline Water}

The PRM aquifer system contains saline water throughout a broad area of southern New Jersey $\left(2,490 \mathrm{mi}^{2}\right)$, extending from the banks of the Delaware River in Salem and Gloucester Counties east through southern Ocean County and to the south, encompassing parts of Burlington, Camden, and Ocean Counties, much of Gloucester and Salem Counties, and all of Atlantic, Cumberland, and Cape May Counties (fig. 20). The presence of saline water in the aquifer system throughout much of southern New Jersey largely resulted from past seawater incursions and the subsequent deposition of paleoseawaters that accompanied eustatic rises in sea level. Long residence times and continued reaction with minerals in the aquifer matrix, particularly in far downdip areas in southern New Jersey, resulted in a dense, highly mineralized, and geochemically mature groundwater. These waters have not yet been flushed with more dilute groundwater from northern recharge areas owing to low freshwater heads at and near the transitional zone. The saltwater front arcs in the updip direction and toward the Delaware River in southern Gloucester County, reflecting predevelopment flow paths and movement of groundwater toward predevelopment discharge areas. Chloride concentrations in the groundwater range from $1 \mathrm{mg} / \mathrm{L}$ to more than $20,000 \mathrm{mg} / \mathrm{L}$, generally increasing in the seaward 


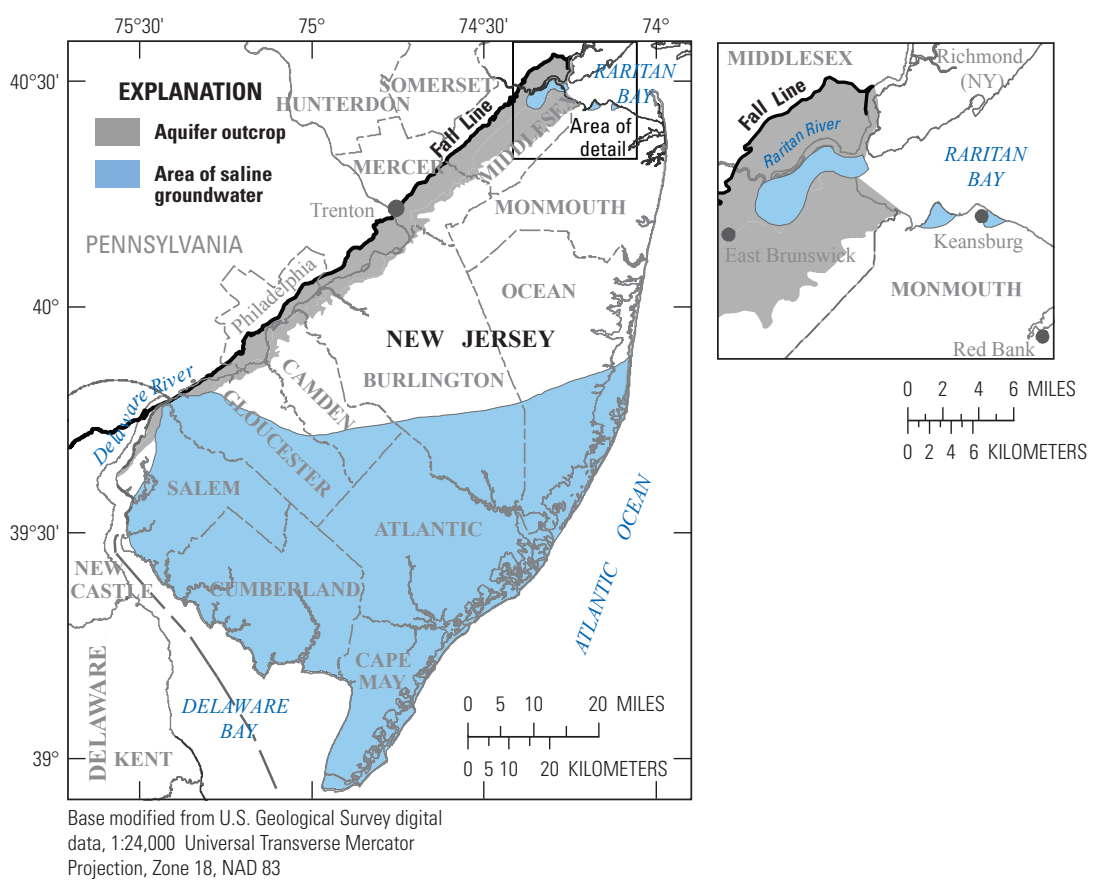

Figure 20. Area of saline groundwater, Potomac-Raritan-Magothy aquifer system, New Jersey, 2008.

direction and with depth throughout the aquifer system. Although saline groundwater in deeper parts of the aquifer system in Salem, Gloucester, and Cumberland Counties occasionally exhibits geochemical properties similar to those of seawater (sodium and bromide to chloride ratios of 0.86 and $1.5 \times 10^{-3}$, respectively), the composition of the groundwater generally indicates a reverse base-exchange reaction, whereby calcium and magnesium ions are lost to sodium-bearing exchange sites, resulting in sodium enrichment of the groundwater (Meisler, 1989). As sodium enrichment progresses, calcium-magnesium to chloride ratios decrease relative to those for seawater. Concurrent increases in boron to chloride ratios in the groundwater relative to seawater are consistent with desorption from clay confining units (Pucci and others, 1997; DePaul and Szabo, 2007; Vinson and others, 2011). Because the aquifer system is in good hydraulic connection with the Delaware River in Camden, Gloucester, and to a lesser degree in Salem County (Navoy and others 2005), induced infiltration during periods of drought and low river discharge may also be a source of chloride contamination in southern New Jersey.

In the northern parts of the Coastal Plain, the PRM aquifer system underlying Middlesex and Monmouth Counties is hydraulically connected to the Raritan and South Rivers, the Washington Canal, and the Raritan Bay, permitting saline water to recharge the aquifer system where prevailing hydraulic gradients are landward (Pucci and others, 1994).

Within the Upper PRM aquifer, freshwater is present throughout much of the updip extent, but saline water is present in Salem County, east through southern Ocean County and south, encompassing most of Atlantic and all of Cumberland and Cape May Counties (pl. 7). Chloride concentrations in the Upper aquifer range from $1 \mathrm{mg} / \mathrm{L}$ to more than 4,000 $\mathrm{mg} / \mathrm{L}$. The lowest concentrations occurred in mid-dip and downdip areas of the aquifer throughout Monmouth, Middlesex, northern Ocean, Burlington, and Camden Counties, where values are less than $10 \mathrm{mg} / \mathrm{L}$. In updip areas adjacent to the aquifer outcrop, concentrations are typically higher, ranging from 2 to $92 \mathrm{mg} / \mathrm{L}$, likely resulting from anthropogenic sources such as road deicers and agricultural runoff in nearby recharge areas. The highest concentrations of chloride were observed in the downdip areas of Salem and Gloucester Counties and in areas of limited extent near the Raritan Bay in northern Monmouth County.

In areas adjacent to, and where the Upper PRM is in good hydraulic connection with, the Raritan Bay, saline water recharges the aquifer underlying parts of Keyport, Union Beach, and Keansburg. Increasing chloride concentrations and the related chemical quality of groundwater during the past decade (1998-2008) indicate continued active saltwater intrusion in this area. From 1998 to 2008 chloride concentrations in wells 25-206 and 25-567 increased at rates of more than $60 \mathrm{mg} / \mathrm{L}$ per year. In southern New Jersey, saline groundwater is present within the aquifer throughout large parts of southern Salem, central and western Gloucester, and southern Camden Counties. Saline groundwater occurs throughout all of Cumberland County and points south and likely beneath 
much of Atlantic and parts of southern Burlington and Ocean Counties. Water-quality data for the area east of Gloucester County is limited, and the location of the freshwater-saltwater interface is inferred from water-quality data for wells located to the north and by the relative position of this interface within the underlying Middle PRM aquifer. Chloride concentrations ranged from less than $1 \mathrm{mg} / \mathrm{L}$ to $30 \mathrm{mg} / \mathrm{L}$ in and around the Camden cone of depression to as high as $250 \mathrm{mg} / \mathrm{L}$ in central Gloucester County. At observation wells in the downdip direction of the saltwater front, chloride concentrations are as high as 3,300 $\mathrm{mg} / \mathrm{L}$. Trends in chloride concentrations are most often upward along this line in the direction of the Camden cone of depression, particularly at production wells in Glassboro and Clayton, although annual rates of increase typically are small.

Within the Middle PRM aquifer, groundwater is generally fresh throughout the northern counties, except in areas where the aquifer underlies or is adjacent to the Raritan and South Rivers in Middlesex County. The recent movement of the saltwater front in the Raritan River and Bay area and the extent of saline groundwater are not fully known because of the lack of current data and wells open to the aquifer; therefore, the mapped location of this line has not changed during the past several data-collection cycles. Recent (2006-8) water-quality data for a limited number of observation wells, however, indicate that moderate to highly saline groundwater $(500-4,800 \mathrm{mg} / \mathrm{L})$ is still (2008) present in the Sayreville area of Middlesex County. Within the southern extent of the Middle PRM aquifer, the saltwater front roughly bisects southern New Jersey from Salem County in the west to southern Ocean County in the east. In similar fashion to the geographic pattern of saltwater occurrence in the Upper aquifer, a tongue of saline groundwater arcs in an updip direction toward areas of higher potentiometric head in central Gloucester County (pl. 8). To the west of this line in Salem County, trends in dissolved chloride in groundwater were not significant or, in some cases, were downward for 1998 to 2008. Northeast of this line, toward the Camden cone of depression but in areas where chloride concentrations are low to moderate (15 to $60 \mathrm{mg} / \mathrm{L}$ ), slight upward trends were sometimes observed for production wells.

The extent of freshwater within the Lower PRM aquifer is shown on plate 9. The location of the saltwater front, based on previously published works by Barksdale and others (1958), Gill and Farlekas (1976), and Schaefer (1983), was updated by using recent water-quality data (DePaul and others, 2009). Chloride concentrations in groundwater from the Lower PRM aquifer ranged from less than $2 \mathrm{mg} / \mathrm{L}$ to more than $11,000 \mathrm{mg} / \mathrm{L}$. The lowest concentrations, which generally did not exceed $20 \mathrm{mg} / \mathrm{L}$, occurred in downdip areas of Burlington and Camden Counties and away from the Delaware River. Highest concentrations of chloride are present in the aquifer underlying much of western Gloucester County and northwestern Salem County and areas to the south and east, where concentrations ranged from 143 to $850 \mathrm{mg} / \mathrm{L}$. The presence of chloride concentrations in excess of $22,000 \mathrm{mg} / \mathrm{L}$ has also been determined in groundwater in eastern Cumberland County where, in the undifferentiated part of the system, highly concentrated brines are encountered at depths of $3,000 \mathrm{ft}$ or greater. The simulated $10,000 \mathrm{mg} / \mathrm{L}$ isochlor trends northeast to southwest from southern Burlington to southern Salem County (Pope and Gordon, 1999). This line, along with the $250-\mathrm{mg} / \mathrm{L}$ isochlor, approximately defines the transition or dispersion zone, whereby fresh and saline groundwater mix primarily through the process of diffusion but by advection and mechanical dispersion as well. The simulated location of this line is $2 \mathrm{mi}$ in the downdip direction from the $250-\mathrm{mg} / \mathrm{L}$ isochlor in Gloucester and $3 \mathrm{mi}$ distant in southern Salem County, indicating a laterally narrow zone of dispersion in places.

\section{Groundwater Flow System}

Groundwater flow in the Potomac-Raritan-Magothy aquifer system is discussed in detail in Martin (1998) and Voronin (2004), and for the Camden area, in Navoy and Carleton (1995). Prior to water-supply development (pre-1900), groundwater flow within the PRM aquifer system was controlled primarily by variations in hydraulic properties of the saturated sediments, as well as by land-surface topography. The aquifer system was recharged by precipitation at outcrop areas in Mercer and Middlesex Counties and by leakage from the overlying Englishtown aquifer system. Groundwater flowed to the east and southeast from topographic highs in Mercer, Monmouth, and Middlesex Counties toward topographic low points near the Raritan Bay and the Atlantic Ocean. Groundwater in the shallow part of the system followed short flow paths and discharged locally to surface-water bodies; water that entered the deeper, regional groundwater flow system followed intermediate and relatively long flow paths toward discharge points beneath the Raritan Bay and Atlantic Ocean. Longer flow paths curved toward the southwest, trending arcuately across, then up the aquifer dip, discharging to the Delaware River and other low-lying surface-water bodies in outcrop areas of Camden, Gloucester, and Salem Counties (Martin, 1998; Spitz and DePaul, 2008).

After development, potentiometric surfaces and groundwater flow patterns in the PRM aquifer system were substantially altered by the location and magnitude of groundwater withdrawals. Withdrawals throughout the system had increased, causing groundwater levels to decline and large cones of depression to form. Long flow paths indicative of the unstressed system were supplanted by short and intermediate flow paths in many places, with groundwater discharging to pumped wells. By the early 1980s, cones of depression had formed in both the Upper and Middle aquifers in the northern section of the Coastal Plain, marked by water levels below $-50 \mathrm{ft}$ in both the Upper and Middle aquifers, and water levels in the Middle aquifer were below -100 ft in northern Monmouth County. In southern New Jersey, regional cones of depression underlying central Camden County extended more 
than 45 miles in the downdip direction and encompassed all three aquifers. By the late 1980s and early 1990s, groundwater levels in the Upper, Middle, and Lower PRM aquifers had reached minima of $-109,-92$, and $-107 \mathrm{ft}$, respectively. Owing to this decline, groundwater flow patterns were reversed such that recharge and discharge were redistributed throughout the system, and areas that once supplied recharge to downdip areas of the aquifer now (2008) supply discharge to production wells. Moreover, areas of discharge, such as those in the southwestern part of the State adjacent to the Delaware River, were converted to recharge areas.

With the establishment of the Critical Areas and associated management strategies, the progressive, long-term declines in groundwater levels began to stabilize and subsequently recover. By 2008 groundwater levels typically recovered from $10 \mathrm{ft}$ to more than $30 \mathrm{ft}$ in the Upper and Middle aquifers across much of Monmouth County, with maximum recoveries of $37 \mathrm{ft}$ and $51 \mathrm{ft}$, respectively. In Middlesex County, recovery of groundwater levels in the Middle aquifer typically ranged from less than $10 \mathrm{ft}$ to $40 \mathrm{ft}$ but was as much as $67 \mathrm{ft}$. Recovery in northern Ocean County was less dynamic and ranged from $2 \mathrm{ft}$ to $25 \mathrm{ft}$. In places, water levels continued to decline in the Upper aquifer. In southern New Jersey groundwater levels recovered by as much as 53,40 , and $50 \mathrm{ft}$ in the Upper, Middle, and Lower aquifers, respectively.

A more detailed discussion of groundwater-level recovery in the PRM aquifers as a result of Critical Area management strategies is provided in Spitz and others (2008), DePaul and others (2009), and Spitz and DePaul (2008). Groundwaterlevel conditions in the PRM aquifer system during fall 2008 are discussed in the following sections.

\section{Upper Potomac-Raritan-Magothy Aquifer}

\section{Water Withdrawals}

Withdrawals from the Upper PRM aquifer are made in Middlesex, Monmouth, and northern Ocean Counties from upland recharge areas to the Atlantic coastline (fig. 21A); however, in the southern part of the study area from Burlington County south to Salem County, withdrawals are confined to a narrow band extending from the aquifer outcrop to about 12 mi downdip. Beyond this limit, depth to the top of the aquifer is substantial and elevated (higher than background) dissolved solids in the groundwater prompts the use of shallower aquifers. The primary pumping centers are located in eastern Middlesex County within and near the outcrop of the Magothy Formation and in central Camden and Gloucester Counties. Substantial withdrawals also are made in northwestern Burlington, northern Ocean, and throughout Monmouth County. Minor withdrawals are made in Mercer County and in Salem County within close proximity to the up dip limit of the aquifer.

Estimated groundwater withdrawals from the Upper PRM aquifer during 1978-2008 ranged from 54.4 to $80.5 \mathrm{Mgal} / \mathrm{d}$; average withdrawals during 2008 were $55.1 \mathrm{Mgal} / \mathrm{d}$ (fig. 22A; table 3). Withdrawals peaked during the early to mid-1980s prior to emplacement of mandatory restrictions and alternative sources of supply. From 1989 to 1995, withdrawals were relatively constant, ranging from 65 to $69 \mathrm{Mgal} / \mathrm{d}$, and were followed by a reduction of $8 \mathrm{Mgal} / \mathrm{d}$ or 12 percent during 1994-95. From 1996 to 2008 withdrawals ranged from 54.4 to $62.9 \mathrm{Mgal} / \mathrm{d}$ with reductions occurring in successive years, except for 2000-1, 2004-5 and 2006-7. Average withdrawals throughout the aquifer during 2008 were about the same as in 2003 .

Upper PRM aquifer withdrawals were highest in Middlesex, Gloucester, and Monmouth Counties, at 15.8, 8.7, and 8.6 Mgal/d, respectively (table 3). Throughout the northern counties average withdrawals during 2008 were $32 \mathrm{Mgal} / \mathrm{d}$, nearly 30 percent greater than those in the southern counties (table 3, fig. 22A). Combined withdrawals from the northern counties peaked from 1981 to 1984 (approximately $47 \mathrm{Mgal} / \mathrm{d}$ ); from 1984 to 2000, withdrawals generally decreased in successive years with the largest reductions occurring during 1988-89. A marked increase occurred during 2001 when withdrawals were 17 percent greater than during the previous year. Withdrawals decreased again by 2003 and were followed by modest increases in 2005 and 2007. In the southern counties, water withdrawals generally were stable (approximately 30-32 Mgal/d) from 1978 through 1995; in 1996 withdrawals decreased to $27 \mathrm{Mgal} / \mathrm{d}$, or by 16 percent, from the year prior. Mandatory restrictions on withdrawals from the Upper PRM aquifer further reduced these amounts, and from 1997 to 2008, withdrawals ranged from 23 to $27 \mathrm{Mgal} / \mathrm{d}$. Average withdrawals during 2008 (23 Mgal/d) were at the low end of this range.

\section{Water Levels}

The potentiometric surface map for 2008 for the Upper PRM aquifer is shown on plate 7; supporting water-level data used to construct this map are provided in appendix 7 . The dominant feature of the potentiometric surface is the extensive cone of depression that extends from the Raritan Bay in the northeastern part of the study area to Salem and Cumberland Counties in the southwest. The highest groundwater altitudes occurred in and near the outcrop area in eastern Mercer and Middlesex Counties; the lowest groundwater altitudes occurred in northern Ocean and central Camden Counties. Previous water-level studies documented low water levels extending into northern Delaware and eastern Maryland (Lacombe and Rosman, 2001; DePaul and others, 2009). Because of the unavailability of data during 2008, groundwater conditions in the Upper PRM aquifer in Delaware were not determined.

The regional cone of depression can be divided into two sub-regional segments, northeastern and southwestern segments. The northeastern sub-regional depression encompasses most of Ocean and Monmouth Counties. This cone of depression has expanded and deepened since the 2003 study as a result of continued increases in groundwater withdrawals. The well-defined center of the cone is beneath pumping centers 

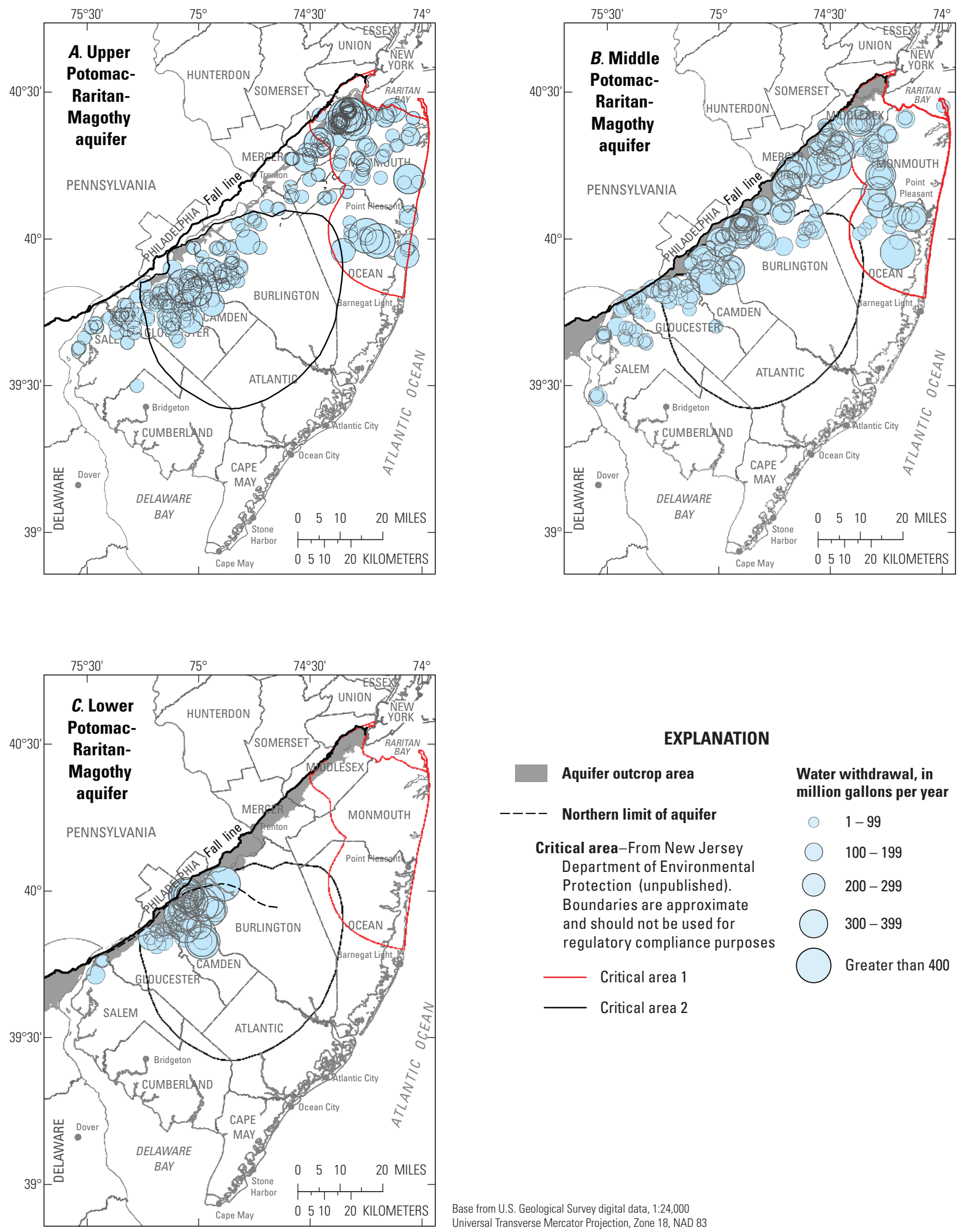

\section{EXPLANATION}

Aquifer outcrop area

Northern limit of aquifer

Critical area-From New Jersey

Department of Environmental

Protection (unpublished).

Boundaries are approximate and should not be used for regulatory compliance purposes

Critical area 1

Critical area 2
Water withdrawal, in million gallons per year

- $\quad 1-99$

100-199

$200-299$

$300-399$

Greater than 400

Base from U.S. Geological Survey digital data, 1:24,000

Universal Transverse Mercator Projection, Zone 18, NAD 83

Figure 21. Location and volume of groundwater withdrawals from $A$, the Upper Potomac-Raritan-Magothy aquifer, $B$, the Middle Potomac-Raritan-Magothy aquifer, and C, the Lower Potomac-Raritan-Magothy aquifer, New Jersey Coastal Plain, 2008. 


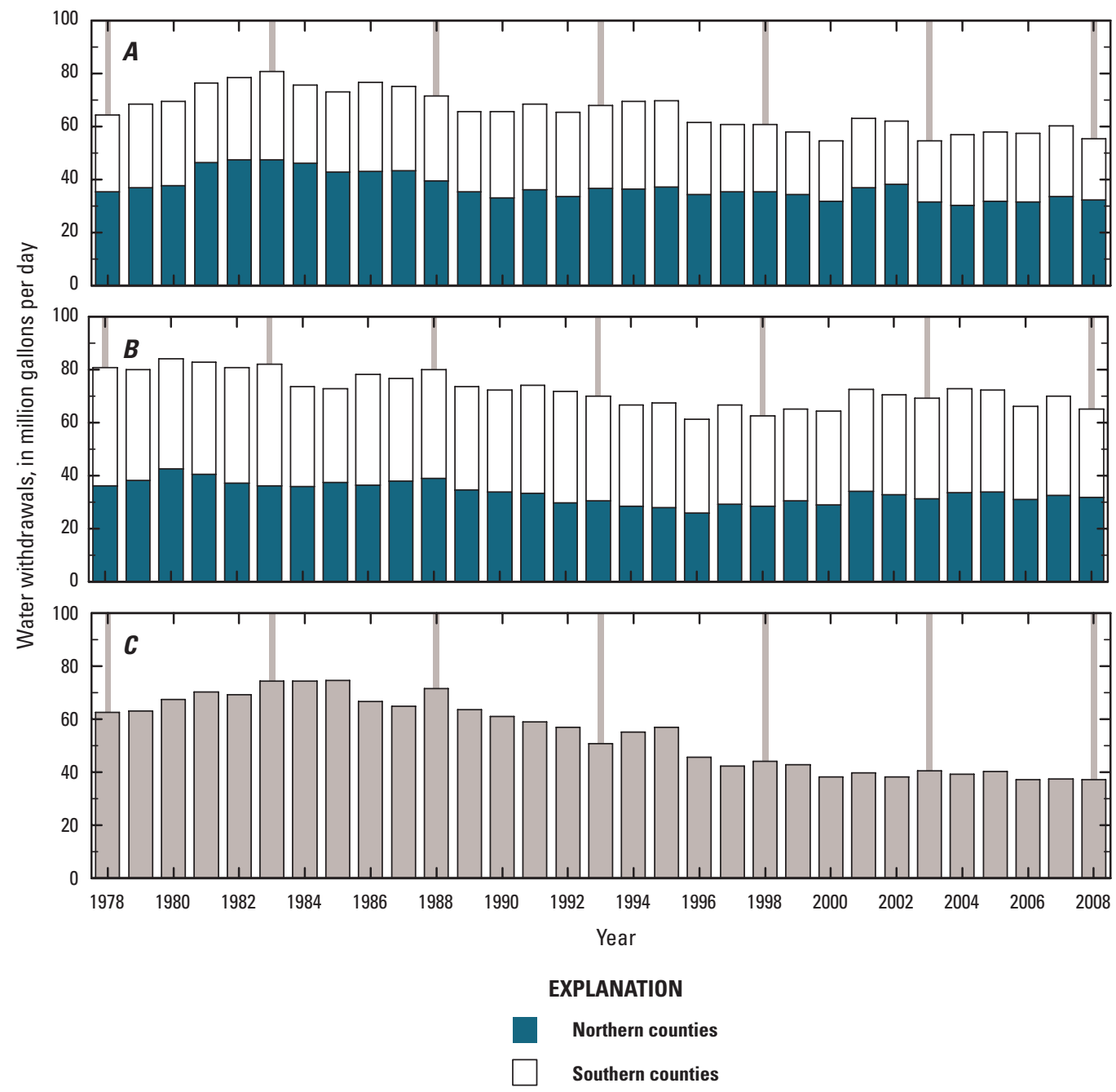

Figure 22. Estimated groundwater withdrawals from $A$, the Upper Potomac-Raritan-Magothy aquifer, $B$, the Middle Potomac-RaritanMagothy aquifer, and $C$, the Lower Potomac-Raritan-Magothy aquifer, New Jersey Coastal Plain, 1978-2008. (Thin vertical bars denote 5 -yr data collection periods)

in Manchester and Toms River Townships and Lakehurst Borough; groundwater altitudes in this area ranged from -81 to $-95 \mathrm{ft}$. Lateral hydraulic gradients are steeper on the updip side of this cone (because of proximity to recharge at and near the outcrop) than on the downdip side; therefore, hydraulic stress extends eastward and beneath the Barnegat Bay, encompassing pumping centers on the barrier island from Mantoloking to Seaside Heights. Moreover, despite constant or decreasing withdrawals on the barrier islands, water levels were generally lower than in 2003 and likely were affected by increases in groundwater withdrawals to the west. The small, localized cone near Seaside Heights has deepened, and water levels throughout the barrier islands declined by $6 \mathrm{ft}$ to as much as $15 \mathrm{ft}$. Approximately $15 \mathrm{mi}$ to the southwest, the water level in well 5-1391 declined by nearly $10 \mathrm{ft}$ to $-35 \mathrm{ft}$, and the area of aquifer encompassed by the $-30 \mathrm{ft}$ potentiometric contour became contiguous with that in southern New Jersey.
Elsewhere throughout the northern counties, water levels ranged from -37 to $76 \mathrm{ft}$ with high altitudes near the outcrop in Mercer and Middlesex Counties and low altitudes at the center of a localized depression near Asbury Park. Such localized depressions were more common in the potentiometric surfaces during previous studies; however, owing to rising water levels in central and northern Monmouth County coupled with declining water levels in southern Monmouth and northern Ocean Counties, such depressions are no longer evident.

The southern segment of the regional cone of depression encompasses much of Burlington, Camden, Gloucester, and eastern Salem Counties. In areas where data are sparse or absent, simulated potentiometric contours by Voronin (2004) were adapted to close the contours on the downdip edge of the regional cone. Groundwater-level altitudes in this segment ranged from highs of $0-19 \mathrm{ft}$ in extreme updip areas of Burlington and Salem Counties to lows of -70 to $-91 \mathrm{ft}$ at and 
near the center of the cone in Berlin, Pine Hill, and Clementon in Camden County and Medford Lakes in Burlington County. From 2003 to 2008, water levels in this central segment, in general, remained stable or had recovered modestly; however, water levels at the center of the cone were as much as $16 \mathrm{ft}$ higher in 2008.

Water-level differences between the Upper and Middle PRM aquifers are generally small to moderate near the outcrop and to about $8 \mathrm{mi}$ downdip, ranging from near neutral to approximately $20 \mathrm{ft}$ and indicating the potential for downward flow out of the Upper PRM aquifer. Vertical head differences in the southwest in Salem County are locally as much as $30 \mathrm{ft}$ along the Delaware River and, in the northeast within and along the outcrop of the Magothy Formation in Middlesex and western Monmouth Counties, range from $20 \mathrm{ft}$ to as much as $50 \mathrm{ft}$ above the potentiometric low in the Middle PRM aquifer. The potential for downward flow from the outcrop to the underlying Middle aquifer is greatest in this area, and the natural flow patterns have been altered such that recharge to the Middle aquifer is enhanced, reducing the volume of groundwater in the Upper aquifer that formerly flowed to the south and east. Because of the reduction of groundwater flow in the Upper aquifer, coupled with the loss of upward discharge beneath the Raritan Bay from both the Upper and Middle PRM aquifers, refreshening of the aquifer in the Union Beach area cannot progress. In eastern Monmouth County, the vertical gradient reverses; groundwater altitudes in the Upper PRM aquifer are as much as 25 feet lower than in the underlying Middle PRM aquifer in the Red Bank, Monmouth County, and area. In north-central Ocean County within the cone of depression near Lakehurst, vertical head differences between the Upper and Middle aquifers increase to nearly $70 \mathrm{ft}$, and the potential for vertical flow is upward into the Upper PRM. In southern New Jersey, near the cone of depression in Camden and Burlington Counties, vertical head differences range from 10 to $20 \mathrm{ft}$, and flow is upward from the Middle aquifer. To the south and southeast (downdip) from the cone of depression, vertical head differences are uncertain owing to the limited amount of data in these areas.

Vertical head differences between the Upper PRM aquifer and the Englishtown aquifer system are substantially greater than those between the Upper and Middle PRM aquifers. Head differences and potential for downward flow into the aquifer are greatest in updip and mid-dip areas. Estimated vertical head differences in 2008 were as much as $104 \mathrm{ft}$ in Camden, $117 \mathrm{ft}$ in Western Monmouth, and $115 \mathrm{ft}$ in northwestern Ocean County. In eastern Monmouth and northeastern Ocean County, however, groundwater altitudes are higher in the Upper PRM than in the Englishtown aquifer system. Despite differences of more than $40 \mathrm{ft}$ between the Upper PRM and the Englishtown aquifer system beneath the cone of depression in eastern Monmouth and Ocean Counties, upward flow is probably limited because of the thickness and low permeability of the overlying Merchantville-Woodbury confining unit (Martin, 1998).
The mapped difference in the potentiometric surfaces of the Upper PRM aquifer from 2003 to 2008 is shown in figure $23 \mathrm{~A}$. Of 182 wells measured in 2003 and 2008, water levels declined in 110 (60 percent) wells in 2008; declines of $5 \mathrm{ft}$ or greater were observed in 50 wells ( 27 percent) and declines of $10 \mathrm{ft}$ or more in 21 wells (12 percent). In contrast, water levels rose in 61 wells ( 34 percent); rises of $5 \mathrm{ft}$ or greater were observed in 27 wells (15 percent), and rises of $10 \mathrm{ft}$ or more were observed in 6 wells ( 3 percent). Water levels remained about the same in 11 wells (6 percent). Results of the Wilcoxon signed-rank test indicate that, on an aquifer-wide basis, water levels were statistically lower in 2008 than in 2003 (appendix 10-2). When grouped by county, this relation held for Monmouth, Ocean, and Salem Counties but was strongest for Monmouth and Ocean, providing further evidence of declining groundwater levels in these areas as shown in figure 23A. In Burlington, Gloucester, and Middlesex Counties, differences in water levels from 2003 to 2008 are not significant; however, differences in Camden County were substantially higher. Similarly, water levels, grouped according to management area, declined in Critical Area 1 but recovered in Critical Area 2. For the 10-year period, significant declines occurred in Critical Area 1, as well as in the subregional group of Middlesex, Monmouth, and Ocean Counties. Water-level increases occurred in Critical Area 2, as well as in the sub-regional group of Burlington, Camden, and Gloucester Counties.

Results of the Mann-Kendall trend analysis are listed in appendix 10-1; supporting water-level hydrographs for the northern and southern counties are shown in figures 24 and 25 , respectively. In the northern counties, water levels followed an upward trend from 2003 to 2008 at two wells (23-292 and 23-228). Trends were insignificant at 3 wells (23-351 25-206, 25-316), and a downward trend was observed at 1 well (25-639). Observation well 25-639 is located in southern Monmouth County at the northern edge of the expanding sub-regional depression. In the southern counties, upward trends from 2003 to 2008 were observed at 2 wells (5-258 and 7-117), and insubstantial trends were observed at 2 wells (7-477 and 15-741). Downward trends were observed at two wells (15-728 and 33-253); both are located beyond the boundary of Critical Area 2. Downward trends for wells in the southern counties, though statistically significant, were generally small with annual rates of decline of less than $0.6 \mathrm{ft}$ that are sometimes difficult to see graphically. The absence of nearby withdrawals and the lack of distinct seasonality in water levels in well 33-253, much like those in observation wells in Delaware, indicate regional influences from withdrawals and sustained head declines in adjacent aquifers on both sides of the Delaware Bay (DePaul and others, 2009).

From 1998 to 2008, for observation wells in the northern counties, trends were similar to those observed during the 5-year period; trends were upward in 2 wells (23-228 and 23-292), insignificant in 3 wells (23-351, 25-206, and 25-316), and downward in well 25-639 along the periphery of the cone 

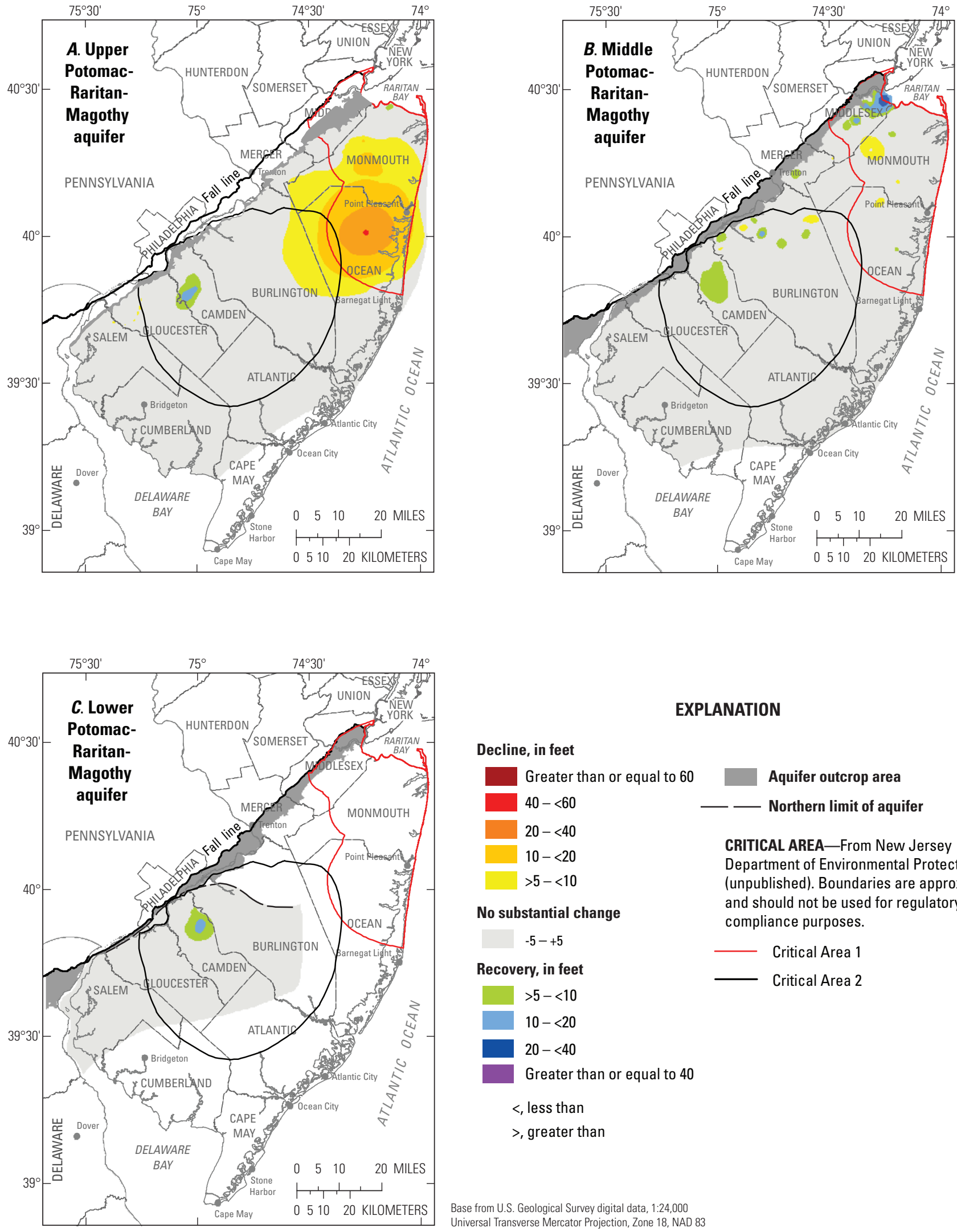

EXPLANATION

Decline, in feet

Greater than or equal to 60
$40-<60$
$20-<40$
$10-<20$
$>5-<10$

No substantial change $-5-+5$ Recovery, in feet

$>5-<10$

$10-<20$

$20-<40$

Greater than or equal to 40

$<$, less than

$>$, greater than

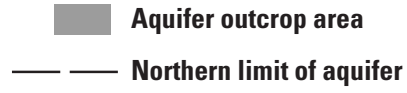

CRITICAL AREA-From New Jersey Department of Environmental Protectionm (unpublished). Boundaries are approximate and should not be used for regulatory compliance purposes.

Critical Area 1

Critical Area 2

Base from U.S. Geological Survey digital data, 1:24,000

Figure 23. Groundwater-level changes in the $A$, Upper Potomac-Raritan-Magothy aquifer, $B$, Middle Potomac-Raritan-Magothy aquifer, and C, Lower Potomac-Raritan-Magothy aquifer, New Jersey Coastal Plain, 2003-8. 


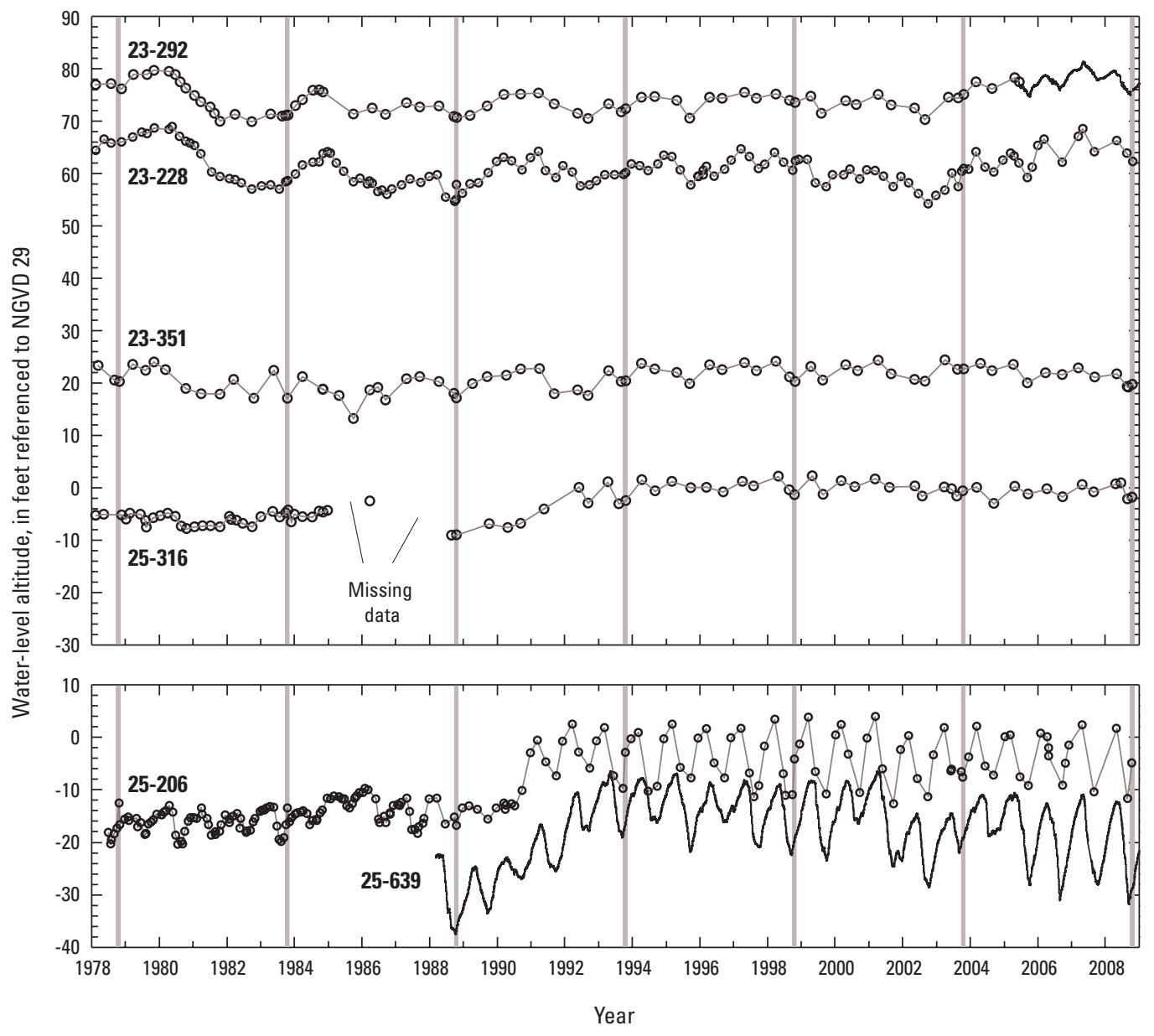

EXPLANATION

Water-level measurement

Continuous

- O Manual

Figure 24. Water-level hydrographs for selected observation wells screened in the Upper Potomac-Raritan-Magothy aquifer in the northern counties, New Jersey Coastal Plain, 1978-2008. (All hydrographs are at the same scale; vertical bars denote 5-yr data collection cycles; well locations shown on pl. 7) 

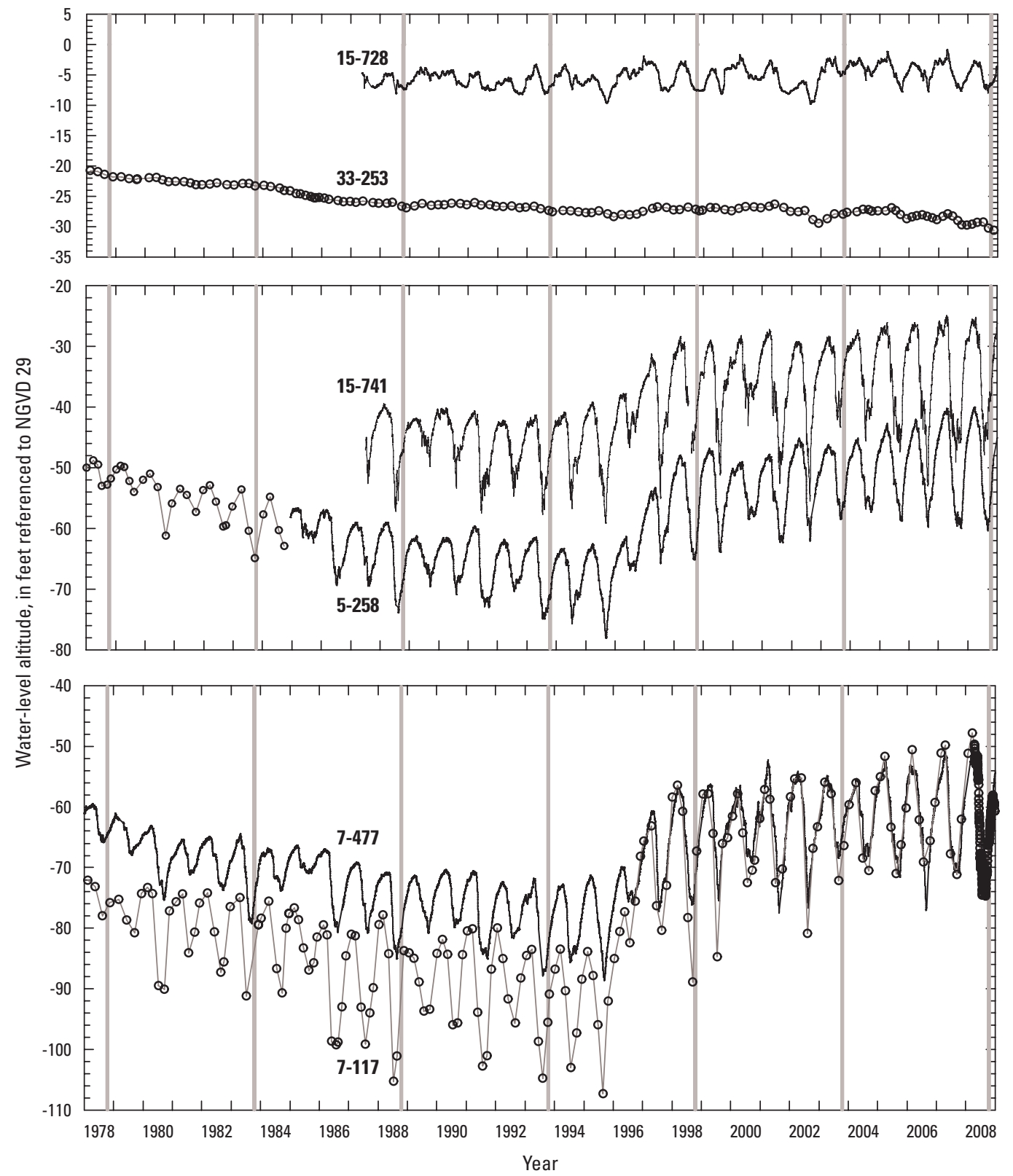

EXPLANATION

Water-level measurement

Continuous

o o Manual

Figure 25. Water-level hydrographs for selected observation wells screened in the Upper Potomac-Raritan-Magothy aquifer in the southern counties, New Jersey Coastal Plain, 1978-2008. (All hydrographs are at the same scale; vertical bars denote 5-yr data collection cycles; well locations shown on pl. 7) 
of depression. For observation wells in the southern counties, trends were upward at four wells $(5-258,7-117,7-477$, and 15-741). The 10-year trend at well 15-728 was considered insignificant; a downward trend was indicated for well 33-253.

In the northern Coastal Plain counties from 1978 to 2008 upward water-level trends were observed at 3 wells (23-292, 25-206 and 25-316), and water-level change was insubstantial at 3 wells (23-228, 23-351, and 25-639) (app. 10-1). The upward trend at well 25-206 was attained largely through a substantial rise in water levels during 1990-92, which corresponds to the cessation of withdrawals from the aquifer. In the southern counties, upward trends in water levels were determined for four wells (same as those for the 10-year period); rates of recovery ranged from 0.36 to $1.13 \mathrm{ft} / \mathrm{yr}$. Results also indicate slightly increasing water levels in well 15-728; however, the annual rate of recovery was considered insubstantial. The highest annual rates of recovery coincided with the steepest lateral hydraulic gradients on the updip side of the regional cone of depression; annual rates of recovery were lower on the northern and downdip sides of the depression. A downward trend was observed for well 33-253 for the 30-year period; the net change in the water level in this well was $9 \mathrm{ft}$.

\section{Middle Potomac-Raritan-Magothy Aquifer}

\section{Water Withdrawals}

Groundwater withdrawals from the Middle and undifferentiated PRM aquifer occurred throughout its extent from the Raritan Bay to Salem County. Primary pumping centers in the aquifer's northern extent are located in eastern Middlesex, northern Monmouth, and northern Ocean Counties and, in the south, Burlington, Camden, Gloucester, and Salem Counties. The distribution of withdrawals is similar to that in the Upper PRM aquifer in that withdrawals are made in the updip and mid-dip areas of the aquifer throughout the northern counties of New Jersey, but withdrawals are confined to a relatively narrow band extending from the outcrop to approximately $8 \mathrm{mi}$ downdip in the southern counties (fig. 21B). Beyond this limit, the presence of elevated concentrations of dissolved solids in the groundwater inhibits development of the aquifer.

Groundwater withdrawals from the Middle PRM aquifer from 1978 to 2008 ranged from 61 to $84 \mathrm{Mgal} / \mathrm{d}$ (fig. 22B). Withdrawals peaked during the early 1980s, but from 1984 to 2000 , withdrawals were reduced by $18 \mathrm{Mgal} / \mathrm{d}$ (22 percent) as a result of mandated Critical Area cutbacks. From 2001 to 2005, however, withdrawals increased by 13 percent. By 2008 average withdrawals throughout the aquifer declined again, and the reported withdrawals of nearly $65 \mathrm{Mgal} / \mathrm{d}$ represent a 6-percent decrease from 2003, the year of the last regional water-level study (table 3).

In the northern counties of New Jersey, average withdrawals ranged from 26 to $43 \mathrm{Mgal} / \mathrm{d}$ from 1978 to 2008. Withdrawals generally decreased during 1980-96; Critical Area restrictions triggered notable single-year reductions from 1988 to 1989 and again from 1991 to 1992 . From 1997 to
2002, withdrawals again increased and by 2005 were approximately $34 \mathrm{Mgal} / \mathrm{d}$. Withdrawals across the northern counties subsequently declined and in 2008 were at $32 \mathrm{Mgal} / \mathrm{d}$, nearly $1 \mathrm{Mgal} / \mathrm{d}$ greater than the 2003 withdrawals. In the northern counties in 2008, average groundwater withdrawals were greatest in Mercer County ( $9 \mathrm{Mgal} / \mathrm{d})$, followed by Middlesex, Monmouth, and Ocean Counties at 8.4, 7.3, and 7.0 Mgal/d, respectively (table 3). Historically, withdrawals among the northern counties were greatest in Middlesex County and, at their maximum in 1980, exceeded $15 \mathrm{Mgal} / \mathrm{d}$. Declining water levels and saltwater encroachment along tidal reaches of the Raritan River and its tributaries led to the systematic reduction of withdrawals in this area, and by 1990, average withdrawals were approximately $8 \mathrm{Mgal} / \mathrm{d}$. Since 1991 , however, average withdrawals throughout Middlesex County increased and receded during successive short 1- to 3-year periods. During 1998-2008, average withdrawals in Middlesex County peaked in 2004 at $11.2 \mathrm{Mgal} / \mathrm{d}$, but withdrawals decreased during 2005-8. In Ocean County, average withdrawals decreased by approximately $7.2 \mathrm{Mgal} / \mathrm{d}$ or 58 percent during 1980-98; thereafter, average withdrawals ranged from 6 to $8 \mathrm{Mgal} / \mathrm{d}$. Withdrawals in Monmouth County followed a similar trend with the smallest annual volumes withdrawn during 1992-97. Withdrawals increased slightly in 1998 and, from 1999 to 2000, ranged from 5.7 to $7.3 \mathrm{Mgal} / \mathrm{d}$. In comparison, withdrawals from the aquifer in Mercer County were relatively constant during the 1980s, ranging from 7 to $8 \mathrm{Mgal} / \mathrm{d}$, increased in 1991, and stabilized through the early 2000s until peaking in 2007 at $9.5 \mathrm{Mgal} / \mathrm{d}$.

Withdrawals from the aquifer in the southern counties were slightly greater on average than those in northern counties during 1978-2008. Average groundwater withdrawals in the southern counties ranged from 33.3 to $46.1 \mathrm{Mgal} / \mathrm{d}$ during the 30-period. Groundwater withdrawals in the combined southern counties peaked in 1983 , decreased by nearly $9 \mathrm{Mgal} / \mathrm{d}$ to $37 \mathrm{Mgal} / \mathrm{d}$ in 1984 and were relatively constant from 1986 to 2007, alternately increasing or decreasing in any given year by 1 to 10 percent. Average withdrawals in 2008 of approximately $33 \mathrm{Mgal} / \mathrm{d}$ were at their lowest levels since 1978. Withdrawals from the aquifer in southern New Jersey were greatest in Burlington County and least in Salem County.

\section{Water Levels}

Water-level data from 173 wells open to the Middle and undifferentiated PRM aquifer are provided in appendix 8; the 2008 potentiometric surface is shown on plate 8 . The highest groundwater-level altitudes in the Middle PRM aquifer occurred near the updip limit in Mercer and Middlesex County, New Jersey. This potentiometric high coincides with groundwater highs in the overlying Upper PRM aquifer and is where the aquifer historically received most of the recharge. The lowest groundwater-level altitudes occurred in central Camden County where they are associated with the longterm regional cone of depression and in southwestern Salem County, adjacent to the Delaware Estuary. The major feature 
of the potentiometric surface is the regionally extensive cone of depression that encompasses much of the study area and extends from the Raritan Bay in the northeast to Salem in the southwest. Much like the regional cone of depression in the Upper PRM aquifer, several discrete sub-regional cones or areas of low potentiometric head are present within the northern, north-central, central, and southwestern parts of the larger cone.

The northern segment underlies eastern Middlesex County and part of northwestern Monmouth County in New Jersey and is within Critical Area 1. Groundwater altitudes in the northern segment of the regional cone ranged from $-11 \mathrm{ft}$ (well 23-194) to -36 ft (well 25-545) in 2008; water levels were lowest along the Raritan Bay front and inland and south to about $6 \mathrm{mi}$. Groundwater altitudes increased toward the outcrop because of topographic influences. The north-central area of the regional cone of depression includes much of southeastern Monmouth County and is within Critical Area 1. Groundwater altitudes in this segment ranged from -11 to -33 ft (wells 23-194 and 25-272); lowest altitudes occurred near pumping centers in and around Freehold, with groundwater altitudes increasing to the north and west.

The central segment of the regional cone of depression underlies a broad area of the New Jersey Coastal Plain, extending from Ocean County southwest to Gloucester County and eastward to Atlantic County; it includes substantial parts of Burlington and Camden Counties. Water-level altitudes in this segment ranged from $0 \mathrm{ft}$ to $-66 \mathrm{ft}$; the lowest water levels were observed in central Camden County and in the vicinity of Marlton in Burlington County. The shape and orientation of the cone of depression is similar to that in the overlying Upper PRM aquifer, though groundwater altitudes generally were higher in the Middle aquifer near its center and on the downdip side, indicating the potential for upward flow out of the aquifer. Lateral hydraulic gradients on the updip side of the cone of depression of nearly $8 \mathrm{ft} / \mathrm{mi}$ are steeper than those in either the Upper or Lower aquifers, although at 1 to $2 \mathrm{ft} / \mathrm{mi}$ on the downdip side, the gradients are similar to those of the Upper aquifer and slightly less than those of the Lower aquifer. Large areas of low hydraulic head are present in central Camden County despite the absence of withdrawals from the Middle aquifer; substantial withdrawals from both the Upper aquifer and the underlying Lower PRM aquifer likely induce leakage through adjacent confining layers, contributing to the depth of the cone of depression here. Near the southeastern edge of this central segment, depths to the top of the aquifer are considerable, and the groundwater is highly mineralized; consequently, few wells are open to the aquifer. Observation well 11-137 in eastern Cumberland County, New Jersey, is the farthest downdip well open to the aquifer included in this study; total dissolved solids in the groundwater are such that the density of the groundwater is substantially greater than fresher waters within other parts of the aquifer. Correcting for density, the measured groundwater altitude of $-52 \mathrm{ft}$ yields a freshwater equivalent of $-29 \mathrm{ft}$. In northern Ocean County, at the northeastern edge of this segment, water levels ranged from -16 ft (well 29-626) to -39 ft (well 29-576); the lowest water levels were measured at or near production wells throughout Jackson Township.

The southwestern segment of the regional cone of depression encompasses Salem County in New Jersey and most of New Castle County in Delaware. Groundwater altitudes in Salem County ranged from -20 ft (wells 33-305 and 33-166) to $-75 \mathrm{ft}$ (well 33-934). Groundwater altitudes were estimated to be highest in the south-central part of Salem County, and measured water levels were lowest along the Delaware River and estuary where localized cones of depression are present in Pennsville and on Artificial Island. Previous studies documented potentiometric lows extending beneath the Delaware Bay and into northern Delaware and eastern Maryland (Lacombe and Rosman, 2001; DePaul and others, 2009). Water-level data for a comparable time period were not available, and groundwater conditions could not be determined.

Water-level differences were small to moderate near the outcrop of the Middle aquifer and to about 8 mi downdip; higher groundwater altitudes in the Middle aquifer indicate a weak downward vertical gradient and the potential for flow into the Lower aquifer. Despite the relatively small vertical head differences between the two aquifers, flow rates between the two may be substantial owing to high leakance of the intervening confining unit (Martin, 1998). On the downdip side of the cone of depression, estimated heads may be higher in the Lower aquifer than in the Middle aquifer, by as much as $15 \mathrm{ft}$, indicating the potential for upward flow into the Middle PRM aquifer. Water-level differences between the Upper PRM aquifer and Middle PRM aquifer are presented in detail in the previous section. In brief, a downward hydraulic gradient is present from the Upper to the Middle PRM aquifer in most places along, and for short distances downdip from, the western boundary of the Upper PRM aquifer. In parts of Monmouth and north-central Ocean County where the Upper PRM aquifer is stressed, the potential for flow is upward through the top of the Middle aquifer. In southern New Jersey, within the regional cone of depression, flow is generally upward through the top of the Middle aquifer.

The 5-year change in water levels in the Middle PRM aquifer is shown in figure $23 \mathrm{~B}$. Of 151 wells measured in both 2003 and 2008, water levels declined in 71 (47 percent) wells in 2008. Declines of $5 \mathrm{ft}$ or greater were observed in 15 wells (10 percent) and of $10 \mathrm{ft}$ or more in only 3 wells. In contrast, water levels recovered in 63 wells (42 percent); rises of $5 \mathrm{ft}$ or greater were observed in 29 wells and of $10 \mathrm{ft}$ or greater in 5 wells (19 percent). Water levels remained about the same in 17 wells (11 percent). Stable or rising water levels were most often associated with the regional cone of depression in Critical Area 2 but were also observed throughout eastern Middlesex and northern Monmouth Counties. Moderate declines were observed in central Monmouth and northern Ocean Counties and in updip areas of Burlington, Gloucester, and Salem Counties, beyond the boundary of Critical Area 2.

Groundwater levels in northern Ocean and southern Monmouth Counties were generally at or slightly below those 
observed during 2003 with declines of 1 to $6 \mathrm{ft}$ typical. In northwestern Monmouth County groundwater levels declined by 5 to $10 \mathrm{ft}$ since 2003, but near the Raritan Bay and in updip sections in Middlesex County, water levels were stable or had recovered. Near the Raritan and South Rivers, water levels showed modest to substantial recovery, ranging from 2 to $8 \mathrm{ft}$, as a result of continued reduction in groundwater withdrawals. Semi-annual water-level data collected from observation wells in this area confirm small to moderate rises from 2003 to 2008 (U.S Geological Survey, 2010). Mapped recovery near the Raritan Bay in Sayreville (greater than $20 \mathrm{ft}$ ) was based on observations at a single well (23-401); however, a review of reported static water-level measurements from nearby production wells during this period indicated rises of at least as much. Such large differences may be an artifact of residual pumping effects during the earlier measurement period; however, rising groundwater levels are likely because withdrawals from the Middle aquifer were discontinued in this area by 2004, and those from the Upper aquifer were minor.

In the central segment and within Critical Area 2, small to moderate recovery of water levels was observed in most wells (range of 2-11 ft), except for scattered wells located along the updip side of the cone and beyond the depleted zone of Critical Area 2. Although withdrawals typically decreased and water levels recovered throughout much of the area, withdrawals at individual wells or small groups of wells have increased since 2003 as a result of temporal and spatial shifts in local pumping patterns, resulting in local declines in groundwater levels. Near the center of the cone of depression, water levels rose 3 to $8 \mathrm{ft}$ in 10 wells and were unchanged in 3 wells. On the downdip side of the cone, water levels recovered slightly. Adjacent to the outcrop in and around Camden, N.J., unchanged water levels or rises of 2 to $4 \mathrm{ft}$ were most common, although combined withdrawals from the Middle and Lower aquifers remained at 2003 volumes. In eastern Cumberland County, far from withdrawal centers, the water level in well 11-137 did not change. Within the southwestern segment of the cone, water levels declined 1 to $5 \mathrm{ft}$ throughout southern Gloucester County and central Salem County.

Results of the Wilcoxon signed-rank test indicate that, from 2003 to 2008, the differences in water levels between paired measurements throughout the aquifer were not significant (app. 10-2). A similar result was calculated for paired measurements from Critical Area 1; however, within Critical Area 2, a significant increase was observed. Significant increases are also indicated for Camden and Middlesex Counties and significant decreases for Gloucester and Salem Counties. Water levels in Monmouth, Ocean, Burlington, and Mercer Counties did not appreciably change. For the period 1998 to 2008, a statistically significant rise in water levels was observed in the study area as a whole, as well as in Critical Area 2; however, differences between paired measurements were not significant throughout Critical Area 1. Results indicate significant increases in water levels in Burlington and Gloucester Counties, significant decreases in water levels throughout Monmouth and Salem Counties, and no significant difference in the paired measurements for Camden, Middlesex, and Ocean Counties.

Water-level hydrographs for seven wells screened in the Middle and undifferentiated aquifer of the PRM aquifer system in the northern counties of New Jersey are shown in figure 26; well locations are shown on plate 8. From 2003 to 2008 , statistically significant downward trends in water levels were detected at wells 29-19 and 29-85 (app. 10-1). Changes were subtle, at $-0.28 \mathrm{ft} / \mathrm{yr}$ at well $29-19$ and $-0.38 \mathrm{ft} / \mathrm{yr}$ at well 29-85 and were, in part, responses to the increased withdrawals and the deepening cone of depression within the Upper PRM aquifer. Water levels in wells 25-635 and 23-291 showed no significant change during this period; however, trend test results indicated a significant rise in the water level in well 25-272. Limited water-level data during targeted periods precluded a statistical analysis of wells 23-97, 23-273, and 23-439. During 1998-2008, downward trends were detected at three observation wells (29-19, 29-85, and 25-635), and an upward trend was detected at well 23-291. No significant upward or downward trends were observed at well 25-272. The water level in observation well 29-19 declined during this period. Although results of the Mann-Kendall produced a p-value of less than 0.001 for well 29-19, the annual rate of decline was less than $0.2 \mathrm{ft}$ and, therefore, was considered unimportant for the purposes of this discussion. During the 30-year period, 1978-2008, upward trends were detected at five wells (23-291, 23-439, 25-272, 25-635, and 29-85); neither an upward nor a downward trend was determined for well 29-19.

Groundwater hydrographs for 10 wells open to the Middle aquifer and the undifferentiated part of the PRM aquifer system in southern counties of New Jersey are shown in figure 27; observation well locations are shown on plate 8 . For the southern counties from 2003 to 2008, upward trends were indicated for 6 wells, and downward trends were indicated for 3 wells. The geographic patterns of both downward and upward trends are consistent with observations based on the water-level-change maps. Upward trends were detected at observation wells within the depleted zone of Critical Area 2, and downward trends were detected beyond the Critical Area 2 boundary and to the southwest in Gloucester and Salem Counties. Seasonal water-level fluctuations and the annual rate of recovery were greatest at wells nearest the cone's center (7-413 and 5-261) and more temperate on the northern and southeastern sides of the cone. Annual rates of decline were highest in mid-dip areas in Salem County (wells 33-187 and 33-251) and moderate in updip areas of Gloucester County. The wider seasonal fluctuations observed in well 33-187 show the effects of nearby production wells at Woodstown; the absence of distinct seasonality in water levels in wells 11-137 and 33-251 illustrate long-term regional trends that are not dominated by the effects of local withdrawals. 

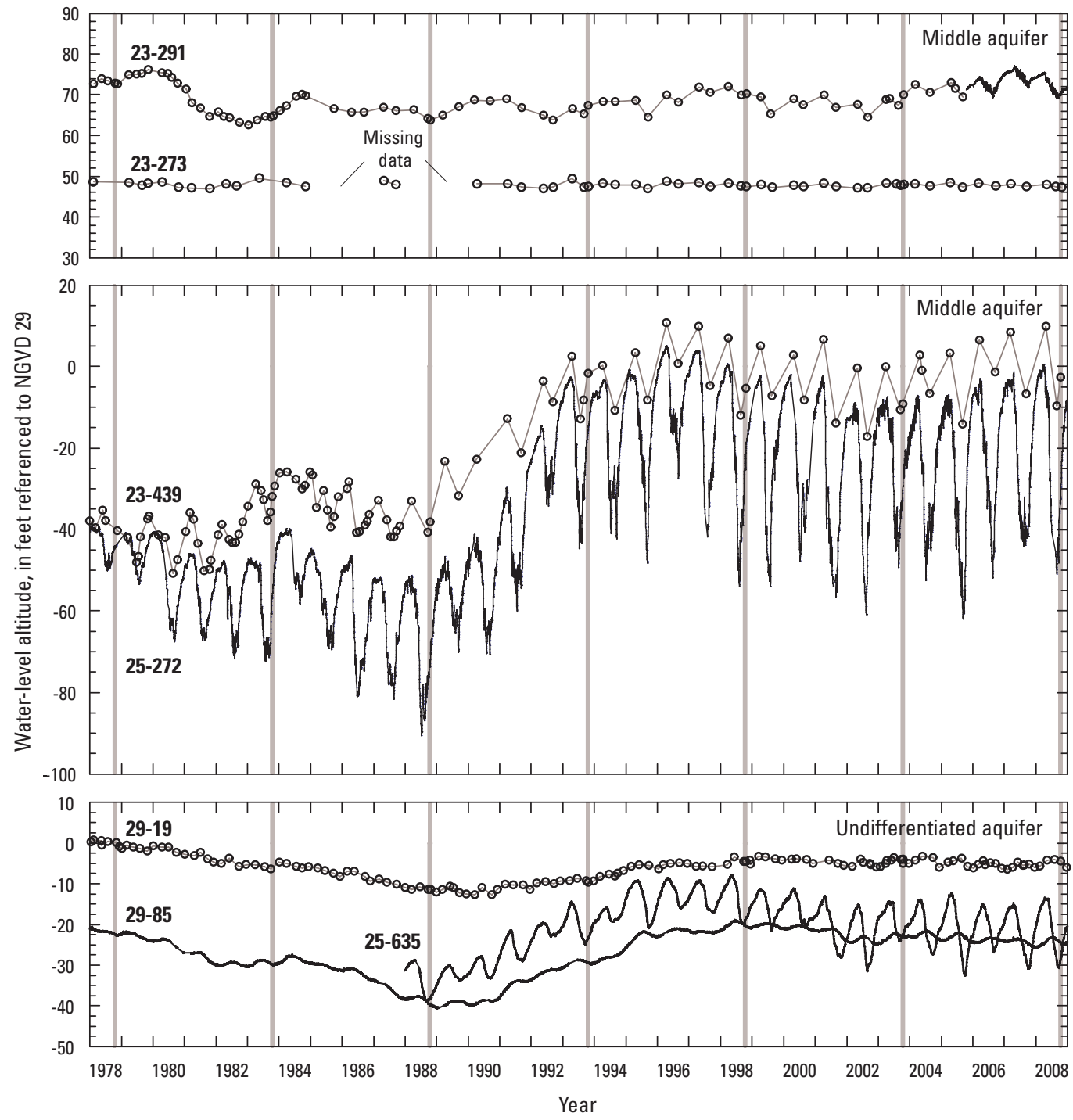

EXPLANATION

Water-level measurement

Continuous

- o Manual

Figure 26. Water-level hydrographs for selected observation wells screened in the Middle and undifferentiated Potomac-RaritanMagothy aquifer in the northern counties, New Jersey Coastal Plain, 1978-2008. (All hydrographs are at the same scale; vertical bars denote 5-yr data collection cycles; well locations shown on pl. 8) 


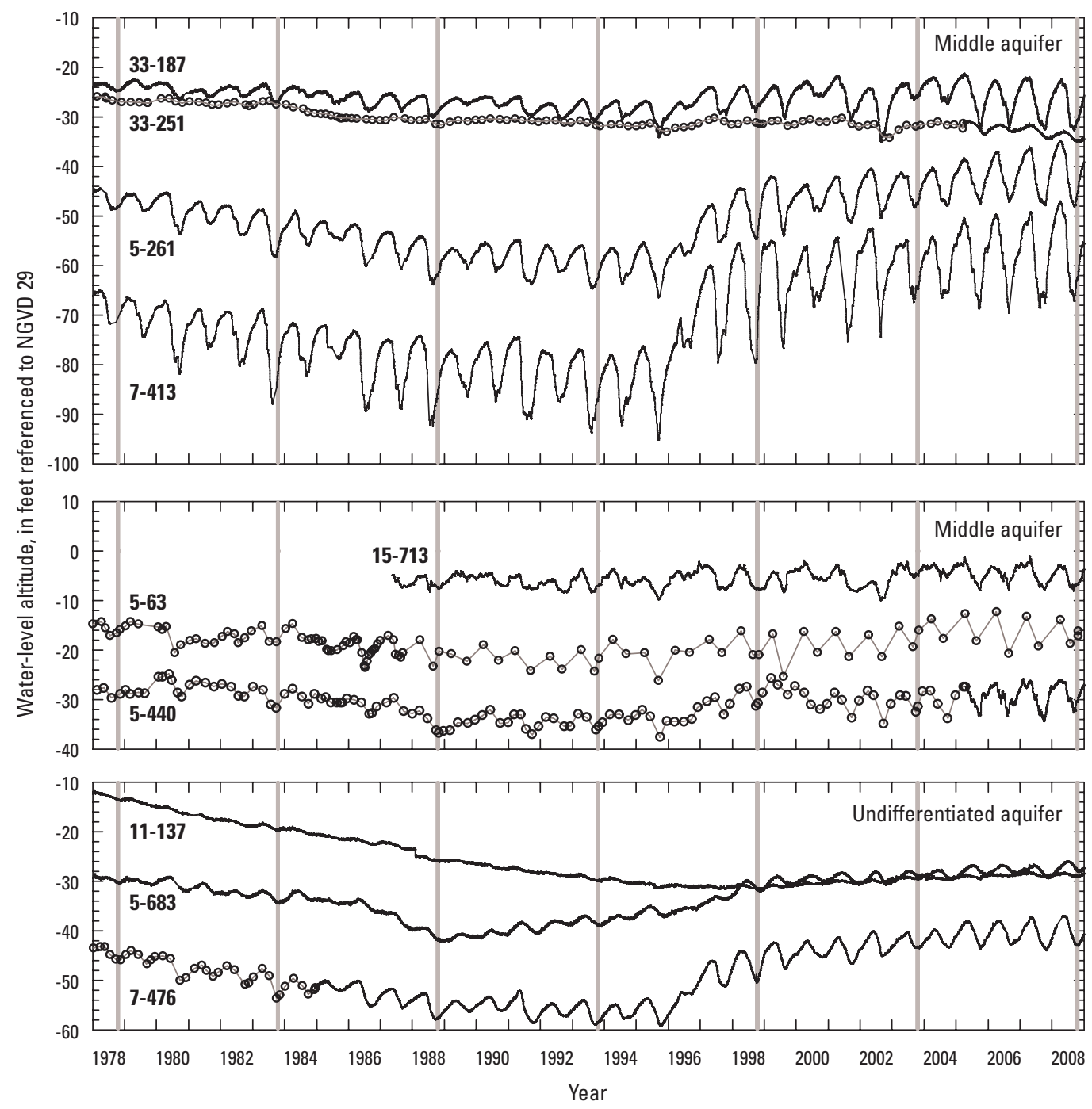

EXPLANATION

Water-level measurement

Continuous

- $\circ$ Manual

Figure 27. Water-level hydrographs for selected observation wells screened in the Middle and undifferentiated Potomac-RaritanMagothy aquifer in the southern counties, New Jersey Coastal Plain, 1978-2008. (All hydrographs are at the same scale; well 11-37 corrected for density; vertical bars denote 5-yr data collection cycles; well locations shown on pl. 8) 


\section{Lower Potomac-Raritan-Magothy Aquifer}

\section{Water Withdrawals}

Groundwater withdrawals from the Lower PRM aquifer in New Jersey were made predominantly in areas adjacent to the Delaware River, with most (approximately $24.4 \mathrm{Mgal} / \mathrm{d}$ or 66 percent) in Camden County (table 3). Most withdrawals were made in the northwestern part of the county near the eastern bank of the Delaware River, although pumping centers are located as far as $11 \mathrm{mi}$ downdip in the central part of the county (fig. 21C). Substantial withdrawals (9.5 Mgal/d) were made in Burlington County along the Camden border and near the northern limit of the aquifer. In Salem and Gloucester Counties, withdrawals were made in the extreme updip parts of the aquifer owing to the presence of saline water in downdip areas. Groundwater withdrawals from the aquifer in Delaware were most common within or near the outcrop area of the Potomac Formation; however, production wells are also located in downdip areas adjacent to the Delaware River (Delaware City).

From 1978 to 2008, average withdrawals from the Lower PRM aquifer ranged from 37 to $75 \mathrm{Mgal} / \mathrm{d}$ (fig. 22C). Withdrawals peaked in the early and mid-1980s; thereafter, withdrawals generally decreased until 2000 and, from 2000 to 2005 , remained constant at approximately 38 to $40 \mathrm{Mgal} / \mathrm{d}$. In 2006, groundwater withdrawals were further reduced by $1 \mathrm{Mgal} / \mathrm{d}$ to $37 \mathrm{Mgal} / \mathrm{d}$. In 2008, average withdrawals were $37 \mathrm{Mgal} / \mathrm{d}$ with 66 percent occurring in Camden County. In Camden County, most withdrawals were made by the Camden City Water Department (United Water Camden), the Merchantville-Pennsauken Water Commission, and New Jersey American Water; together these utilities accounted for 78 percent of withdrawals in the county during 2008.

Trends in withdrawals throughout Camden and Gloucester Counties were similar to regional trends, and although the percentage of reductions was higher in Gloucester County, reductions in volume were much greater in Camden County. Reductions of 20 percent or greater from the previous year occurred in 1989, 1991, 2000, and 2006 in Gloucester County; in Camden County, reductions of 10 percent or greater occurred in 1986, 1989, 1993, 1996, and 2006. In Burlington County, withdrawals generally increased from 1978 through 1990, and during the ensuing decade withdrawals were relatively constant, ranging from 8 to $10 \mathrm{Mgal} / \mathrm{d}$. During 2001-4 withdrawals nominally decreased, and during 2005-8, withdrawals increased by nearly 30 percent. These large increases were associated with the city of Camden wells located along, but just beyond, the boundary of Critical Area 2. In Salem County, withdrawals were limited because of the widespread presence of saline groundwater. Withdrawals were relatively small at approximately $1 \mathrm{Mgal} / \mathrm{d}$ from 1982 to 2006, although withdrawals in Salem County peaked during the early 1990s at nearly $1.5 \mathrm{Mgal} / \mathrm{d}$. Notable reductions in withdrawals (20 percent or greater) from any given year to the next occurred during 1985, 1994, 2000, and 2007.
Withdrawals from the aquifer in Delaware ranged from approximately 3.5 to more than $8 \mathrm{Mgal} / \mathrm{d}$ during 1978-2001 and peaked during 1999-2001 (DePaul and others, 2009). Recent data (2002-8) for this aquifer in Delaware were not tabulated for this study.

\section{Water Levels}

The potentiometric surface map for fall and early winter 2008 for the Lower Potomac-Raritan-Magothy aquifer is shown on plate 9; water-level data used to construct this map are listed in appendix 9. Most of the water-level measurements were made at wells located within New Jersey (80); 8 wells in Delaware and 3 in Pennsylvania were included. Despite the limited availability of water-level data, interpretation of the potentiometric surface was extended into northeastern Delaware, given the lateral flow beneath the bay and the effect of long-term withdrawals in Delaware on low water levels observed in southwestern New Jersey In addition, the cone of depression in Delaware historically has been well documented and mapped.

The configuration of the potentiometric surface in New Jersey is a generally ovate depression, slightly elongated from northeast to southwest along strike and centered beneath the Camden County community of Gibbsboro. The location and configuration of the cone of depression are similar to those in the overlying Middle and Upper PRM aquifers, though the Lower aquifer is shallower at its center and slightly updip from the Middle aquifer. Lateral hydraulic gradients on the updip side of the cone of approximately $8 \mathrm{ft} / \mathrm{mi}$ are similar to those of the Middle aquifer along the same hydrogeologic section; the estimated lateral gradient of $2.5 \mathrm{ft} / \mathrm{mi}$ on the downdip side is slightly greater than that of the Middle aquifer.

During 2008, water-level altitudes ranged from $4 \mathrm{ft}$ to $-66 \mathrm{ft}$ throughout southern New Jersey. Throughout the aquifer, groundwater altitudes typically were at or below $0 \mathrm{ft}$; water levels greater than $0 \mathrm{ft}$ occurred adjacent to the Delaware River along the northwestern boundary of the aquifer in Burlington County and immediately adjacent to the updip boundary in New Castle County, Del. The lowest water levels were observed in central Camden County. The general direction of lateral groundwater flow is dominated by the large cone of depression in central Camden and is similar to that in the southern extents of the Upper and Middle PRM aquifers; flow moves radially from the updip and downdip margins of the aquifer toward potentiometric lows at pumping centers. A groundwater divide is present approximately along the border between Gloucester and Salem Counties; beyond this divide, groundwater flow is to the southwest and beneath the Delaware Bay toward the regional cone of depression in Delaware. Water-level differences between the Middle and Lower PRM aquifers are discussed in the previous section, which describes water levels within the Middle PRM aquifer in detail.

The 5-year change in water levels in the Lower PRM aquifer is shown in figure $23 \mathrm{C}$. Of the 84 wells measured in both 2003 and 2008, water levels in 2008 were lower in 
22 of the wells ( 26 percent); however, all declines in New Jersey were typically less than $5 \mathrm{ft}$ (water levels in one well in Delaware declined by $6 \mathrm{ft}$ ) and are represented as no substantial change in figure $23 C$. Water levels increased in 54 wells (64 percent) and remained the same in 8 (10 percent). Water levels increased in 12 wells by more than $5 \mathrm{ft}$ relative to 2003; these changes occurred primarily in wells in north-central Camden County and southwestern Burlington County.

Results of the Wilcoxon signed-rank test indicate increasing water levels from 2003 to 2008 in the Lower aquifer as a whole, in Critical Area 2, and in Camden County (app. 10-2). Test results indicate differences in water levels throughout Burlington and Gloucester Counties were insignificant likely because scattered, modest declines and rises within the aquifer offset one another. For 1998-2008, a statistically significant increase was observed in the aquifer as a whole, in Critical Area 2, and in Burlington, Camden, and Gloucester Counties.

Groundwater hydrographs for seven monitoring wells in southern New Jersey and northern Delaware are presented in figures 28 and 29; well locations are shown on plate 9. Results of the Mann Kendall trend test (app. 10-1) indicate that, from 2003 to 2008 upward trends were observed for four wells (5-262, 7-412, 15-671, and Dc34-05). A downward trend was indicated for 1 well (15-712), and water-level changes were insignificant for 2 wells. Much like recent trends in the Upper and Middle PRM aquifers, upward trends observed within Critical Area 2 were strongest for wells located nearest the center of the cone of depression. Water levels observed at Dc34-05, located within the outcrop of the Potomac Formation on the northeastern side of the cone of depression in east-central New Castle County, Del., followed a pattern similar to that observed in Db33-17. From 1984 to 2003, water levels in both wells, despite numerous brief periods of decline and recovery, generally did not change, and from 2003 to 2008, water levels recovered slightly. On the other hand, water levels in well Ec32-07, located on the southern side of the cone of depression, declined from the early 1980 s through 2007 , followed by rising water levels in 2008.

During 1998-2008, upward trends were indicated for 3 wells (5-262, 7-412, and 15-671), a downward trend was indicated for 1 well (Ec32-07), and an insubstantial trend was indicated for well 15-712. For the 30-year period, water-level trends were upward for 4 wells, downward for 1 well, and insubstantial for 1 well (appendix 10-1).

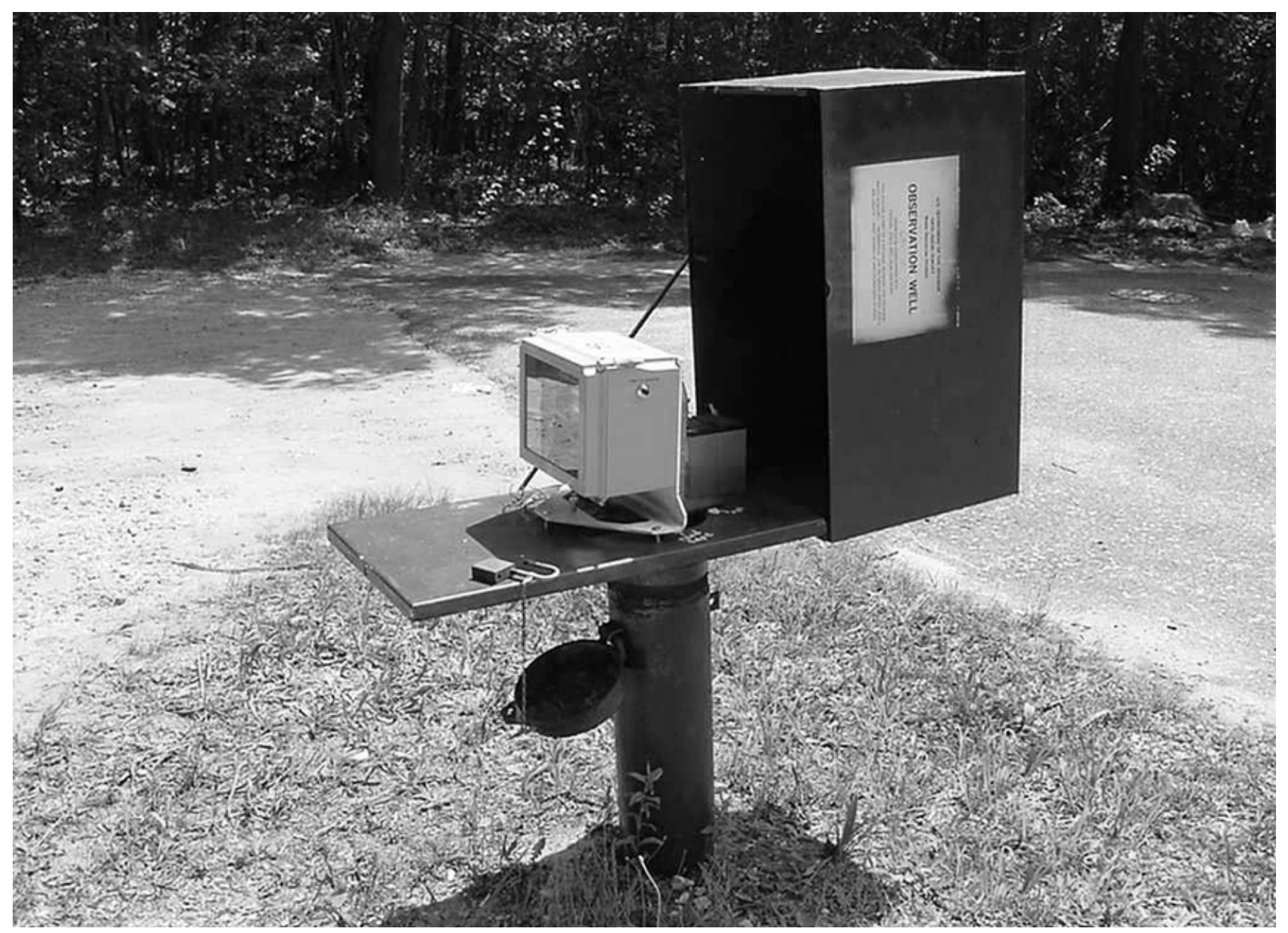

Photograph was provided by U.S. Geological Survey field personnel 


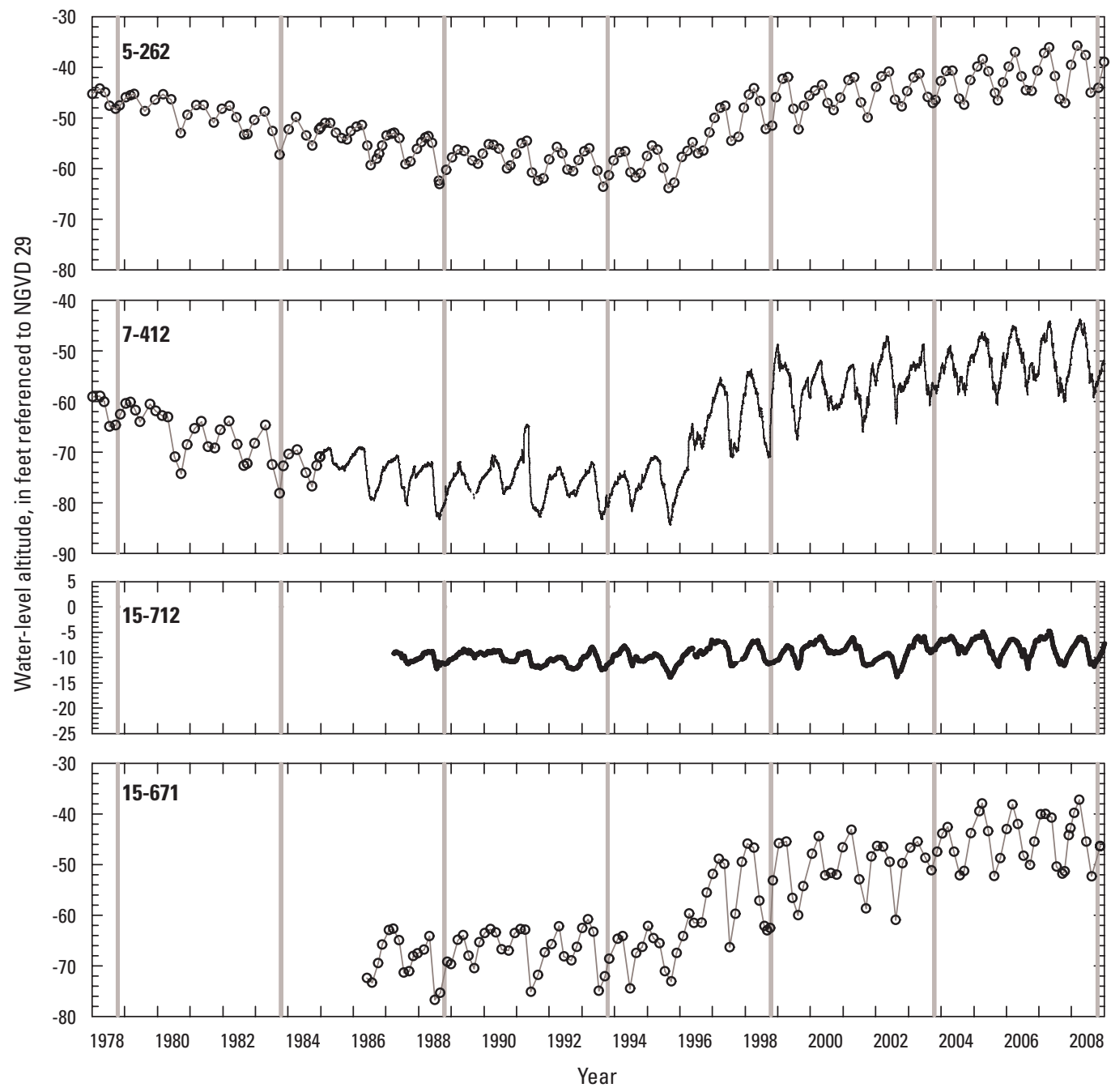

EXPLANATION

Water-level measurement

Continuous

o o Manual

Figure 28. Water-level hydrographs for selected observation wells screened in the Lower Potomac-Raritan-Magothy aquifer, New Jersey Coastal Plain, 1978-2008. (All hydrographs are at the same scale; vertical bars denote 5-yr data collection cycles; well locations shown on pl. 9) 


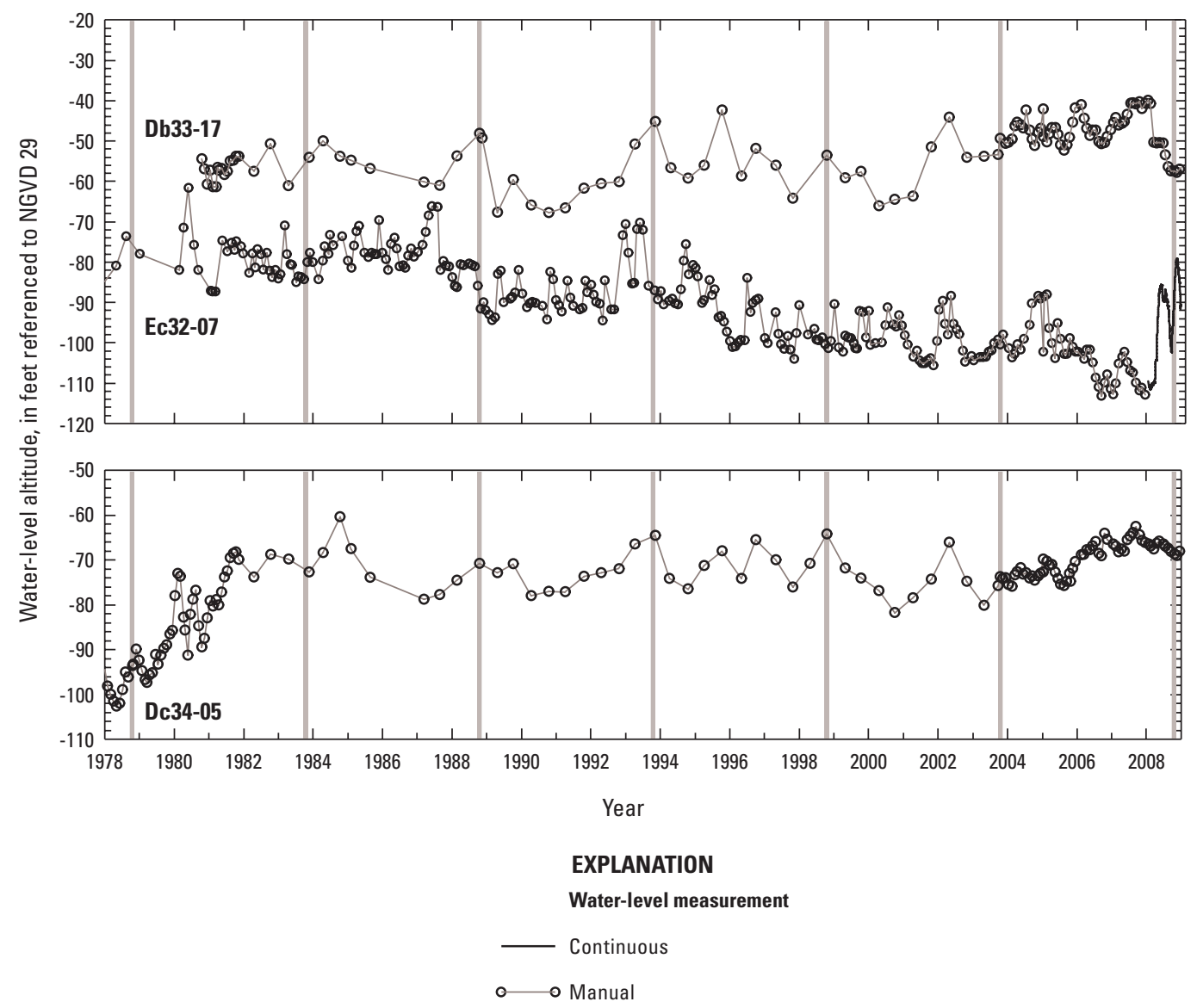

Figure 29. Water-level hydrographs for selected observation wells screened in the Lower Potomac-Raritan-Magothy aquifer, Delaware Coastal Plain, 1978-2008. (All hydrographs are at the same scale; vertical bars denote 5-yr data collection cycles; well locations shown on pl. 9)

\section{Potentiometric Heads in Relation to the Tops of Aquifers}

Withdrawals from confined aquifers can reduce the pressure head, resulting in a lowering of the potentiometric surface, but in most cases do not cause a dewatering of the aquifer. Desaturation of confined aquifers can lead to adverse effects, such as the compression of the aquifer materials (resulting in decreased porosity and hydraulic conductivity) and the deterioration of water quality by enhanced leakage through confining units of poor water quality, as well as through potential oxidation reactions with the aquifer matrix. In order to identify areas within selected confined aquifers that are potentially unsaturated, the altitudes of the 2008 potentiometric surfaces were compared to digital surfaces of the associated hydrogeologic unit-top altitudes. Raster datasets representing the differences between the two surfaces were created and contoured by using GIS software. The contours of the differences were then manually adjusted on the basis of the current understanding of the hydrogeologic framework of the
Coastal Plain. Analyses were conducted for aquifers characterized by persistent potentiometric lows: the Atlantic City 800 -foot sand, the Piney Point aquifer, the Wenonah-Mount Laurel aquifer, the Englishtown aquifer system, and the Upper, Middle, and Lower aquifers of the PRM aquifer system. Selected analyses and maps (fig. 30) are provided for informative purposes only and are best not applied at a local scale. In the updip areas of the aquifers, the height of hydraulic head above the unit top approaches zero as distance from the outcrop decreases and is presumed to be at or near zero at the downdip edge of the outcrop. Given the presence of an unsaturated zone throughout much of the extent of the outcrops, this difference is expected to be less than zero within the outcrop, except at discharge points near lakes, streams, and major rivers. Because water-level measurements from wells at the downdip edges of the aquifer outcrops are generally not made during data-collection cycles, the density and configuration of available water-level data in these areas are not sufficient for substantive interpretation. In downdip areas of confined aquifers, however, a negative value would indicate that the potentiometric surface is below the unit top and thus, the 

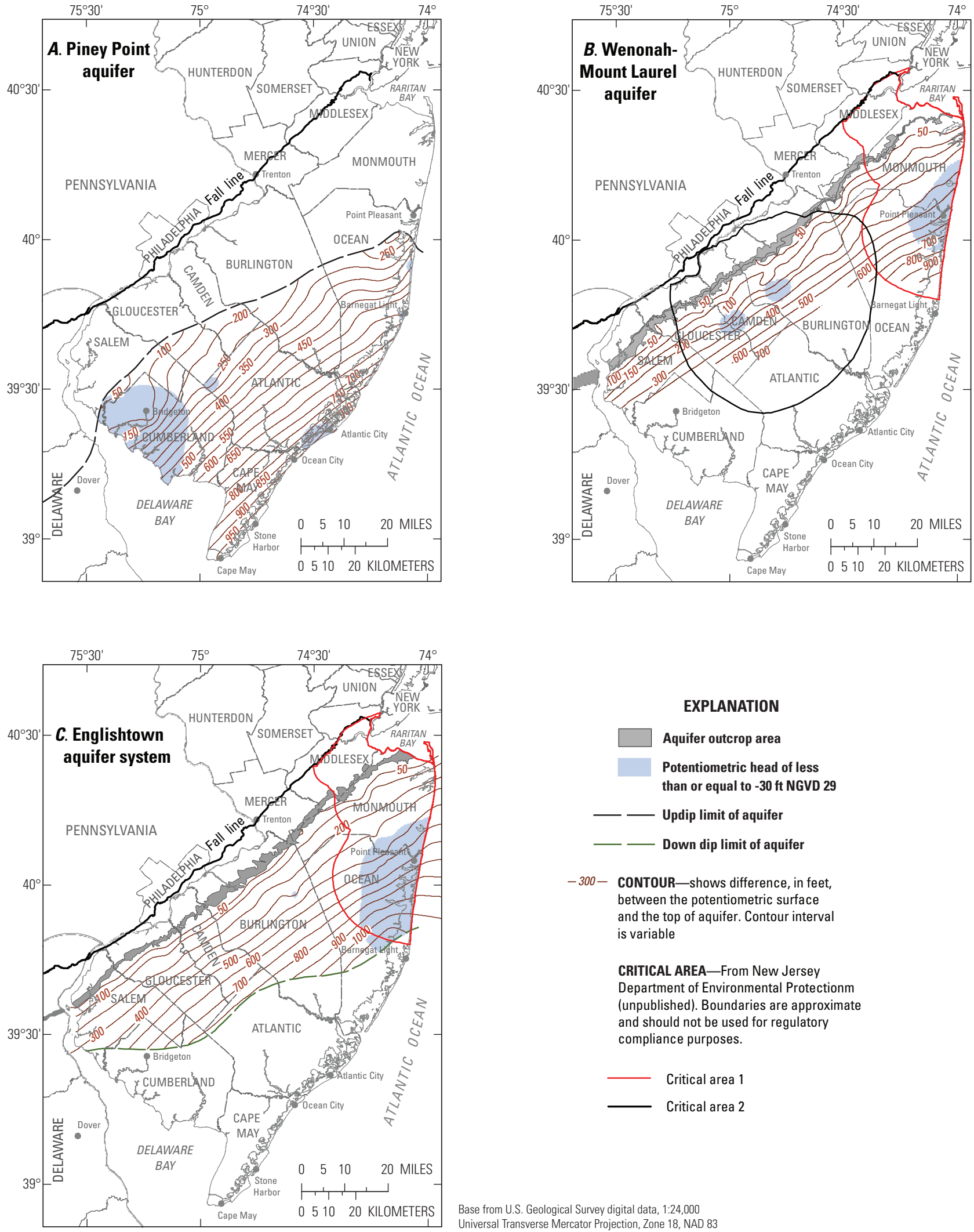

\section{EXPLANATION}

Aquifer outcrop area

Potentiometric head of less than or equal to -30 ft NGVD 29

— Updip limit of aquifer

—_ Down dip limit of aquifer

-300- CONTOUR-shows difference, in feet between the potentiometric surface and the top of aquifer. Contour interval is variable

CRITICAL AREA-From New Jersey Department of Environmental Protectionm (unpublished). Boundaries are approximate and should not be used for regulatory compliance purposes.

- Critical area

Critical area 2

Figure 30. Available feet of potentiometric head above the top of the $A$, Piney Point aquifer, $B$, Wenonah-Mount Laurel aquifer, and $C$, Englishtown aquifer system, central and southern New Jersey, 2008. 
aquifer is potentially desaturated. On the basis of these comparisons, altitudes of selected 2008 potentiometric surfaces do not approach unit-top altitudes in areas away from outcrops. In areas of extreme potentiometric lows, such as the Piney Point aquifer in Cumberland County, the minimum available head above the top of the aquifer was approximately $50 \mathrm{ft}$ where the cone of depression intersected the updip boundary, and available head averaged more than $150 \mathrm{ft}$ throughout the deepest part of the cone (fig. 30). In comparison, within the deep cones of depression in the Englishtown aquifer system and Wenonah-Mount Laurel aquifer, minimum available head above the unit tops was $310 \mathrm{ft}$ and $230 \mathrm{ft}$, respectively (along the updip edge of the $-30 \mathrm{ft}$ contour for 2008), and available heads averaged $680 \mathrm{ft}$ and $470 \mathrm{ft}$, respectively. Even at their lowest historical levels during the mid-1980s, potentiometric heads within the Englishtown aquifer system and Wenonah Mount Laurel aquifer exceeded the unit-top altitudes by a minimum of $275 \mathrm{ft}$ and $145 \mathrm{ft}$, respectively. Within the Critical Area 2 cones of depression, as defined by the $-30 \mathrm{ft}$ contour for the Lower PRM aquifer, groundwater altitudes in the PRM aquifer system exceeded unit-top altitudes on average by more than $370 \mathrm{ft}$ for each of the three units $(371,560$, and $860 \mathrm{ft}$; Upper, Middle, and Lower aquifers, respectively). Minimum available potentiometric heads during 2008, observed near the updip edges of the cones of depression, were 42, 75 , and $195 \mathrm{ft}$ in the Upper, Middle, and Lower PRM aquifers, respectively.

\section{Summary}

Groundwater levels measured in 936 wells in New Jersey, eastern Pennsylvania, eastern Maryland, and northern Delaware during fall 2008 were used to map the potentiometric surfaces of 10 confined aquifers in the New Jersey Coastal Plain. Potentiometric surface maps were prepared for the confined Cohansey aquifer in Cape May County, the Rio Grande water-bearing zone, the Atlantic City 800-foot sand, the Piney Point aquifer, the Vincentown aquifer, the Wenonah-Mount Laurel aquifer, the Englishtown aquifer system, and the Upper, Middle, and Lower aquifers of the Potomac-Raritan-Magothy (PRM) aquifer system.

Water-level differences, evaluated in 800 wells measured during the fall of 2003 and 2008, indicate small to moderate changes in many Coastal Plain aquifers in New Jersey. Groundwater levels stabilized or had recovered, but in places, water levels continued to decline as a result of withdrawals. In the confined Cohansey aquifer in Cape May, groundwater altitudes generally did not change. Groundwater levels in the Atlantic City 800-foot sand typically were below those in 2003; declines were greatest near pumping centers in coastal Atlantic County. Changes were less pronounced in Cape May County, and water levels were, on average, less than $3 \mathrm{ft}$ lower than those measured during the previous study in 2003, except near Rio Grande, N.J., where a localized cone of depression had formed as a result of increased withdrawals. Large and widespread water-level declines were observed in the Piney Point aquifer in Cumberland County where water levels fell in excess of $100 \mathrm{ft}$ in and around Bridgeton and by 30 to $60 \mathrm{ft}$ in surrounding areas. Groundwater levels in the Wenonah-Mount Laurel aquifer and Englishtown aquifer system continued to recover in Critical Area 1. In Critical Area 2 water levels in the Wenonah-Mount Laurel aquifer continued to decline.

In the Upper Potomac-Raritan-Magothy aquifer, groundwater levels were substantially lower than those observed in 2003 in parts of northern Ocean County but did not change appreciably in the Raritan Bay area, and water levels continued to recover in Critical Area 2. In the Middle Potomac-Raritan-Magothy aquifer, water levels recovered near the Raritan and South Rivers in Middlesex County; however, modest declines occurred in the interior parts Monmouth and Ocean Counties. Groundwater levels in both the Middle and Lower PRM aquifers were stable to recovering in Critical Area 2. Beyond Critical Area 2 in southern New Jersey, however, water levels were slightly lower than in 2003.

Water-level trends were calculated for 73 wells for the 30-year period (1978-2008) and for 77 wells for both the 10-year (1998-2008) and 5-year (2003-8) periods. Results of analyses of long-term water-level changes show that, during 1978-2008, trends were downward at 20 wells (27 percent), upward at 27 wells (37 percent), and were insubstantial or insignificant at 26 wells (36 percent). Declining water levels were observed most often in wells screened within the Atlantic City 800-foot sand where rates of decline ranged from less than 0.1 to 1 foot per year ( $\mathrm{ft} / \mathrm{yr}$ ) and in wells in the Piney Point aquifer in southern New Jersey where rates of decline were as much as $1.4 \mathrm{ft} / \mathrm{yr}$. Upward water-level trends were observed commonly for wells in the Englishtown aquifer system and the Wenonah-Mount Laurel aquifer in Critical Area 1 and in the PRM aquifer system in parts of Critical Area 1 and most of Critical Area 2. Annual rates of increase ranged from 1.1 to $5.6 \mathrm{ft}$ in the Englishtown aquifer system and Wenonah-Mount Laurel aquifer. For the aquifers of the PRM aquifer system, annual rates of recovery were greatest in the Lower aquifer.

From 1998 to 2008, downward water-level trends were observed for 22 wells ( 29 percent), upward trends for 21 wells (27 percent), and insubstantial trends for 34 wells (44 percent). Downward water-level trends were observed most often for wells open to the Piney Point aquifer and the Atlantic City 800 -foot sand; rates of decline ranged from less than 0.2 to $7.6 \mathrm{ft} / \mathrm{yr}$. Upward trends were observed mostly for wells open to the Englishtown aquifer system in Critical Area 1 and for wells within the PRM aquifer system in Critical Area 2 and southern New Jersey.

From 2003 to 2008, downward trends were observed for 30 wells ( 39 percent), upward trends for 20 wells ( 26 percent), and insubstantial or insignificant trends for 27 wells (35 percent). The geographic pattern of water-level trends for the 30 -year period was similar to that for the 10 -year period (1998-2008); however, annual rates of decline markedly increased throughout the Atlantic City 800-foot sand and the 
Piney Point aquifer in southern New Jersey where water levels declined by as much as $9.4 \mathrm{ft} / \mathrm{yr}$.

Long-term withdrawals from confined aquifers of the New Jersey Coastal Plain have resulted in the lowering of the potentiometric surface in places but have not caused aquifer dewatering within the study area. In areas of persistent low water levels and deep cones of depression, available potentiometric head above the tops of the aquifers is sufficient, and no evidence of desaturation was observed.

\section{References Cited}

Anderson, H.R., and Appel, C.A., 1969, Geology and groundwater resources of Ocean County, New Jersey: New Jersey Department of Conservation and Economic Development, Special Report No. 29, 93 p.

Barksdale, H.C., Johnson, M.E., Baker, R.C., Schaefer, E.J., and DeBuchananne, G.D., 1943, The groundwater supplies of Middlesex County, New Jersey: New Jersey State Water Policy Commission Special Report 8, 160 p.

Barksdale, H.C., Greenman, D.W., Lang, S.M., Hilton, G.S., and Outlaw, D.W., 1958, Groundwater resources in the tri-state region adjacent to the lower Delaware River: New Jersey Department of Conservation and Economic Development Special Report 13, 190 p.

Charles, E.G., Nawyn, J.P., Voronin, L.M., and Gordon, A.D., 2011, Simulated effects of allocated and projected 2025 withdrawals from the Potomac-Raritan-Magothy aquifer system, Gloucester and Northeastern Salem Counties, New Jersey: U.S. Geological Survey Scientific Investigations Report 2011-5033, 145 p.

Cushing, E.M., Kantrowitz, I.H., and Taylor, K.R., 1973, Water resources of the Delmarva Peninsula: U.S. Geological Survey Professional Paper 822, 58 p., 12 pls.

DePaul, V.T., and Szabo, Zoltan, 2007, Occurrence of radium-224, radium-226, and radium-228 in water from the Vincentown and Wenonah-Mount Laurel aquifers, the Englishtown aquifer system, and the Hornerstown and Red Bank Sands, southwestern and south-central New Jersey: U.S. Geological Survey Scientific Investigations Report 2007-5064, 62 p.

DePaul, Vincent, Rosman, Robert, and Lacombe, P.J., 2009, Water-level conditions in selected confined aquifers of the New Jersey and Delaware Coastal Plain, 2003: U.S. Geological Survey Scientific Investigations Report 2008-5145, 123 p., 9 pl.
Eckel, J.A., and Walker, R.L., 1986, Water levels in major artesian aquifers of the New Jersey Coastal Plain, 1983: U.S. Geological Survey Water-Resources Investigations Report 86-4028, 62 p., 7 pls.

Farlekas, G.M., Nemickas, Bronius; Gill, H.E., 1983, Geology and ground-water resources of Camden County, New Jersey: U.S. Geological Survey Water-Resources Investigations Report 83-4029, 158 p.

Gilbert, R.O., 1987, Statistical methods for environmental pollution monitoring: New York, Van Nostrand Reinhold Company, 320 p.

Gill, H.E., 1962, Groundwater resources of Cape May County, New Jersey-Saltwater invasion of principal aquifers: New Jersey Department of Conservation and Economic Development, Division of Water Policy and Supply Special Report 18, $171 \mathrm{p}$.

Gill, H.E., and Farlekas, G.M., 1976, Geohydrologic maps of the Potomac-Raritan-Magothy aquifer system in the New Jersey Coastal Plain: U.S. Geological Survey Hydrologic Investigations Atlas HA-557, 2 sheets, scale 1:500,000.

Hardt, W.F., and Hilton, G.S., 1969, Water resources and geology of Gloucester County: New Jersey Department of Conservation and Economic Development, Division of Water Policy and Supply Special Report 30, 130 p.

Helsel, D.R., and Hirsch, R.M., 2002, Statistical methods in water resources: U.S. Geological Survey Techniques of Water Resources Investigations, book 4, chap. A3, 522 p.

Hirsch, R.M., and Slack, J.R., 1984, A nonparametric trend test for seasonal data with serial dependence: Water Resources Research, v. 20, p. 727-732.

Jablonski, L.A., 1968, Groundwater resources of Monmouth County, New Jersey: Department of Conservation and Economic Development Special Report 23, 114 p.

Johnson, M.L., and Charles, E.G., 1997, Hydrology of the unconfined aquifer system, Salem River Area: Salem River and Raccoon, Oldmans, Alloway, and Stow Creek Basins, New Jersey, 1993-94: U.S. Geological Survey WaterResources Investigations Report 96-4195, 5 sheets.

Johnson, M.L., and Watt, M.K., 1996, Hydrology of the unconfined aquifer system, Mullica River Basin, New Jersey, 1991-92: U.S. Geological Survey Water-Resources Investigations Report 94-4234, 6 sheets.

Lacombe, P.J., and Carleton, G.B., 2002, Hydrogeologic framework, availability of water supplies, and saltwater intrusion, Cape May County, New Jersey: U.S. Geological Survey Water-Resources Investigations Report 01-4246, $151 \mathrm{p}$. 
Lacombe, P.J., Carleton, G.B., Pope, D.A., and Rice, D.E., 2009, Future water-supply scenarios, Cape May County, New Jersey, 2003-50: U.S. Geological Survey Scientific Investigations Report 2009-5187, 159 p.

Lacombe, P.J., and Rosman, Robert, 1995, Hydrology of the unconfined aquifer system in the upper Maurice River Basin and adjacent areas in Gloucester County, New Jersey, 1986-87: U.S. Geological Survey Water-Resources Investigations Report 92-4128, 3 sheets.

Lacombe, P.J., and Rosman, Robert, 1997, Water levels in, extent of freshwater in, and water withdrawals from eight major confined aquifers, New Jersey Coastal Plain, 1993: U.S. Geological Survey Water-Resources Investigations Report 96-4206, 8 pls.

Lacombe, P.J., and Rosman, Robert, 2001, Water levels in, extent of freshwater in, and water withdrawals from ten major confined aquifers, New Jersey Coastal Plain, 1998: U.S. Geological Survey Water-Resources Investigations Report 00-4143, 10 pls.

Lettini, B.P., Wright, J.D., Szabo, Zoltan, and DePaul, V.T., 2003, Possible effects of pore water from confining units on geochemistry of water in the Piney Point aquifer in New Jersey: Geological Society of America Abstracts, v. 35, no. 3 , p. 31 .

Mann, H.B., 1945, Non-parametric tests against trend: Econometrica v. 13 , p. 245-259.

Martin, Mary, 1984, Simulated ground-water flow in the Potomac aquifers, New Castle County, Delaware: U.S. Geological Survey Water-Resources Investigations Report 84-4007, 85 p.

Martin, Mary, 1998, Ground-water flow in the New Jersey Coastal Plain: U.S. Geological Survey Professional Paper $1404 \mathrm{H}, 146$ p.

McAuley, S.D., Barringer, J.L., Paulachok, G.N., Clark, J.S., and Zapecza, O.S., 2001, Ground-water flow and quality in the Atlantic City 800-foot sand, New Jersey: New Jersey Geological Survey Report GSR 41, 86 p.

McLaughlin, P.P., and Velez, C.C., 2006. Geology and extent of the confined aquifers of Kent County, Delaware: Delaware Geological Survey Report of Investigations No. 72, $40 \mathrm{p}$.

Meisler, Harold, 1989, The occurrence and geochemistry of salty ground water in the northern Atlantic Coastal Plain: U.S. Geological Survey Professional Paper 1404 D, 51 p., $6 \mathrm{pl}$.
Navoy, A.S., Voronin, L.M., and Modica, Edward, 2005, Vulnerability of production wells in the Potomac-RaritanMagothy aquifer system to saltwater intrusion from the Delaware River in Camden, Gloucester, and Salem Counties, New Jersey: U.S. Geological Survey Scientific Investigations Report 2004-5096, 35 p.

Navoy, A.S., 1994, Simulated effects of projected withdrawals from the Wenonah-Mount Laurel aquifer on ground-water levels in the Camden, New Jersey, area and vicinity: U.S. Geological Survey Water-Resources Investigations Report 92-4152, $22 \mathrm{p}$.

Navoy, A.S., and Carleton, G.B., 1995, Groundwater flow and future conditions in the Potomac-Raritan-Magothy aquifer system, Camden area, New Jersey: New Jersey Geological Survey Report GSR 38, 183, 184 p.

New Jersey Administrative Code, 2004, Safe drinking water act regulations: title 7, chapter 10, subchapter 7: Trenton, N.J., 83 p.

New Jersey Administrative Code, 2005, New Jersey water supply allocation rules: title 7 , chapter 19 , subchapter 8 : Trenton, N.J., 82 p.

New Jersey Department of Environmental Protection, 2012, New Jersey Department of Environmental Protection Open Public Records Act, DEP-Data Miner-Water Allocation: Trenton, N.J., accessed January 10, 2011, at http:// datamine2.state.nj.us/DEP_OPRA/OpraMain/categories? category $=$ Water + Allocation .

New Jersey Water Supply Authority, 2005, Annual report of the New Jersey Water Supply Authority: Clinton, N.J., accessed June 14, 2007, at http://www.njwsa.org/2005 Annual_Report.pdf.

Nichols, W.D., 1977, Geohydrology of the Englishtown formation in the northern Coastal Plain of New Jersey: U.S. Geological Survey Water-Resources Investigations Report 76-123, $62 \mathrm{p}$.

Owens, J.P., Minard, J.P., Sohl, N.F., and Mello, J.F., 1970, Stratigraphy of the outcropping Post-Magothy Upper Cretaceous formations in southern New Jersey and northern Delmarva Peninsula, Delaware, and Maryland: U.S. Geological Survey Professional Paper 674, 60 p.

Pope D.A., and Gordon, A.D., 1999, Simulation of groundwater flow and movement of the freshwater-saltwater interface in the New Jersey Coastal Plain: U.S. Geological Survey Water-Resources Investigations Report 98-4216, $159 \mathrm{p}$. 
Pope, D.A., 2006, Simulation of proposed increases in groundwater withdrawals from the Atlantic City 800-foot sand, New Jersey Coastal Plain: U.S. Geological Survey Scientific Investigations Report 2006-5114, 17 p.

Pucci, A.A., Jr., Pope, D.A., and Gronberg, J.M., 1994, Hydrogeology, simulation of ground-water flow and saltwater intrusion, Potomac-Raritan-Magothy aquifer system, northern Coastal Plain of New Jersey: New Jersey Geological Survey GSR-36, 206 p.

Pucci, A.A., Jr., Szabo, Zoltan, and Owens, J.P., 1997, Variations in pore-water quality, mineralogy, and sedimentary texture of clay-silts in the lower Miocene Kirkwood Formation, Atlantic City, New Jersey, in Miller, K.G., and Snyder, S.W., eds., Proceedings of the Ocean Drilling Program, Scientific Results, v. 150X, p. 317-341. (Also available at http://wwwodp.tamu.edu/publications/150X_SR/24X_CHP. $P D F$.)

Rosenau, J.C., Lang, S.M., Hilton, G.S., and Rooney, J.G., 1969, Geology and groundwater resources of Salem County, New Jersey: New Jersey Department of Conservation and Economic Development Special Report 33, 142 p.

Rosman, Robert, Lacombe, P.J., and Storck, D.A., 1996, Water levels in the major artesian aquifers of the New Jersey Coastal Plain, 1988: U.S. Geological Survey WaterResources Investigations Report 95-4060, 74 p., 7 pls.

Rush, F.E., 1968, Geology and groundwater resources of Burlington County, New Jersey: New Jersey Department of Conservation and Economic Development Special Report 26, 45 p.

Schaefer, F.L., 1983, Distribution of chloride concentrations in the principal aquifers of the New Jersey Coastal Plain, 1977-81: U.S. Geological Survey Water-Resources Investigations Report 83-4061, 56 p.

Seaber, P.R., 1965, Variations in chemical character of water in the Englishtown Formation, New Jersey: U.S. Geological Survey Professional Paper 498-B, 35 p.

Sen, P.K., 1968, Estimates of the regression coefficient based on Kendall's tau: Journal of the American Statistical Association, v. 63, p.1379-1389.

Spitz, F.J., 1998, Analysis of ground-water flow and saltwater encroachment in the shallow aquifer system of Cape May County, New Jersey: U.S. Geological Survey Water-Supply Paper 2490, $51 \mathrm{p}$.

Spitz, F.J., Watt, M.K., and DePaul, V.T., 2008, Recovery of ground-water levels from 1988 to 2003 and analysis of potential water-supply management options in Critical Area 1, east-central New Jersey: U.S. Geological Survey Scientific Investigations Report 2007-5193, 40 p.
Spitz, F.J., and DePaul, V.T., 2008, Recovery of ground-water levels from 1988 to 2003 and analysis of effects of 2003 and full-allocation withdrawals in Critical Area 2, southern New Jersey: U.S. Geological Survey Scientific Investigations Report 2008-5142, 28 p.

Sugarman, P.J., 1992, Geologic controls on aquifer distribution in the Coastal Plain of New Jersey, in Gohn, G.S., ed., Proceedings of the 1988 U.S. Geological Survey Workshop on the Geology and Geohydrology of the Atlantic Coastal Plain: U.S. Geological Survey Circular 1059, p. 35-38.

Sugarman, P.J., and Miller, K.G., 1997, Correlation of Miocene sequences and hydrogeologic units, New Jersey Coastal Plain: Sedimentary Geology, v. 108, p. 3-18.

Sugarman, P.J., Miller, K.G., Browning, J.V., and others, 2005, Millville site report, Initial Reports ODP Leg 174AX, Supplement: College Station, Texas, Texas A\&M University, Ocean Drilling Program, 94 p.

Sugarman, P.J., 2001, Hydrostratigraphy of the Kirkwood and Cohansey Formations of Miocene Age in Atlantic County and vicinity, New Jersey: New Jersey Geological Survey Geological Survey Report 40, 26 p

Sugarman, P.J., Miller, K.G., Browning, J.V., Kulpecz, A.A., McLaughlin, P.P., and Monteverde, D.H., 2005, Hydrostratigraphy of the New Jersey Coastal Plain: sequences and facies predict continuity of aquifers and confining units: Stratigraphy, v. 2, p. 259-275.

Todd, D.K., 1980, Groundwater hydrology: New York, John Wiley \& Sons, 535 p.

U.S. Fish and Wildlife Service, 1990, Digital wetlands delineation maps (data base): St. Petersburg, Fla., U.S. Fish and Wildlife Service.

U.S. Geological Survey, 2010, Water resources data for New Jersey, water year 2009, volume 2: U.S. Geological Survey WDR-US-2009, Ground Water Data, CD-ROM, unpaginated.

Vengosh, A., 2003, Salinization and saline environments, in Sherwood Lollar, Barbara, ed., Treatise on geochemistry, v. 9: Amsterdam, Elsevier, p. 333-365.

Vinson, D., Schwartz, H., Dwyer, G., and Vengosh, A., 2011, Evaluating salinity sources of groundwater and implications for sustainable reverse osmosis desalination in coastal North Carolina, USA: Hydrogeology Journal, v. 19, p. 981-994.

Voronin, L.M., 2004, Documentation of revisions to the Regional Aquifer System Analysis model of the New Jersey Coastal Plain: U.S. Geological Survey Water-Resources Investigations Report 03-4268, 49 p. 
Voronin, L.M., Spitz, F.J., and McAuley, S.D., 1996, Evaluation of saltwater intrusion and travel time in the Atlantic City 800-foot sand, Cape May County, New Jersey, 1992, by use of a coupled-model approach and flow-path analysis: U.S. Geological Survey Water-Resources Investigations Report 95-4280, 38 p.

Vroblesky, D.A., and Fleck, W.B., 1991, Hydrogeologic framework of the Coastal Plain of Maryland, Delaware, and District of Columbia: U.S. Geological Survey Professional Paper 1404-E, 45 p.

Walker, R.L., 1983, Evaluation of water levels in major aquifers of the New Jersey Coastal Plain, 1978: U.S. Geological Survey Water-Resources Investigations Report 82-4077, $56 \mathrm{p}$.

Watt, M.K., 2000, A hydrologic primer for New Jersey watershed management: U.S. Geological Survey WaterResources Investigations Report 00-4140, 108 p.

Watt, M.K., and Johnson, M.L., 1992, Water resources of the unconfined aquifer system of the Great Egg Harbor River Basin, New Jersey, 1989-90: U.S. Geological Survey Water-Resources Investigations Report 91-4126, 5 pls.

Watt, M.K., Johnson, M.L., and Lacombe, P.J., 1994, Hydrology of the unconfined aquifer system, Toms River, Metedeconk River, and Kettle Creek Basins, New Jersey, 1987-90: U.S. Geological Survey Water-Resources Investigations Report 93-4110, 5 sheets.
Watt, M.K., Kane, A.C., Charles, E.G., and Stork, Donald, 2003, Hydrology of the unconfined aquifer system, Rancocas Creek Area: Rancocas, Crosswicks, Assunpink, Blacks, and Crafts Creek Basins, New Jersey, 1996: U.S. Geological Survey Water-Resources Investigations Report 02-4280, 5 pls.

Wilcoxon, F., 1945, Individual comparisons by ranking methods: Biometrics, v. 1, p. 80-83.

Winkler, S., 2004, A user-written SAS program for estimating temporal trends and their magnitude: St. Johns Water Management District Technical Publication SJ2004-4, 37 p.

Woodruff, K.D., 1969, The occurrence of saline groundwater in Delaware aquifers: Delaware Geological Survey Report of Investigations 13, 45 p.

Zapecza, O.S., Voronin, L.M., and Martin, Mary, 1987, Ground-water-withdrawal and water-level data used to simulate regional flow in the major Coastal Plain aquifers of New Jersey: U.S. Geological Survey Water-Resources Investigations Report 87-4038, 120 p.

Zapecza, O.S., 1989, Hydrogeologic framework of the New Jersey Coastal Plain: U.S. Geological Survey Professional Paper 1404-B, 49 p., 24 pls. 


\section{Appendixes 1-10.}

\section{Tables}

1-1. Water-level data for wells screened in the confined Cohansey aquifer, New Jersey Coastal Plain, 1978-2008

1-2. Water-level data for wells screened in the Rio Grande water-bearing zone, New Jersey Coastal Plain, 1978-2008

2. Water-level data for wells screened in the Atlantic City 800-foot sand, New Jersey Coastal Plain, 1978-2008

3. Water-level data for wells screened in the Piney Point aquifer, New Jersey Coastal Plain, 1978-2008

4. Water-level data for wells screened in the Vincentown aquifer, New Jersey Coastal Plain, 1978-2008

5. Water-level data for wells screened in the Wenonah-Mount Laurel aquifer, New Jersey Coastal Plain, 1978-2008

6. Water-level data for wells screened in the Englishtown aquifer system, New Jersey Coastal Plain, 1978-2008

7. Water-level data for wells screened in the Upper Potomac-Raritan-Magothy aquifer, New Jersey Coastal Plain, 1978-2008

8. Water-level data for wells screened in the Middle and undifferentiated Potomac-Raritan-Magothy aquifer, New Jersey Coastal Plain, 1978-2008

9. Water-level data for wells screened in the Lower Potomac-Raritan-Magothy aquifer, New Jersey Coastal Plain, 1978-2008

10-1. Results of the Mann-Kendall trend test on water levels from selected observation wells, New Jersey Coastal Plain, 1978-2008

10-2. Results of the Wilcoxon signed-rank test for paired water levels 


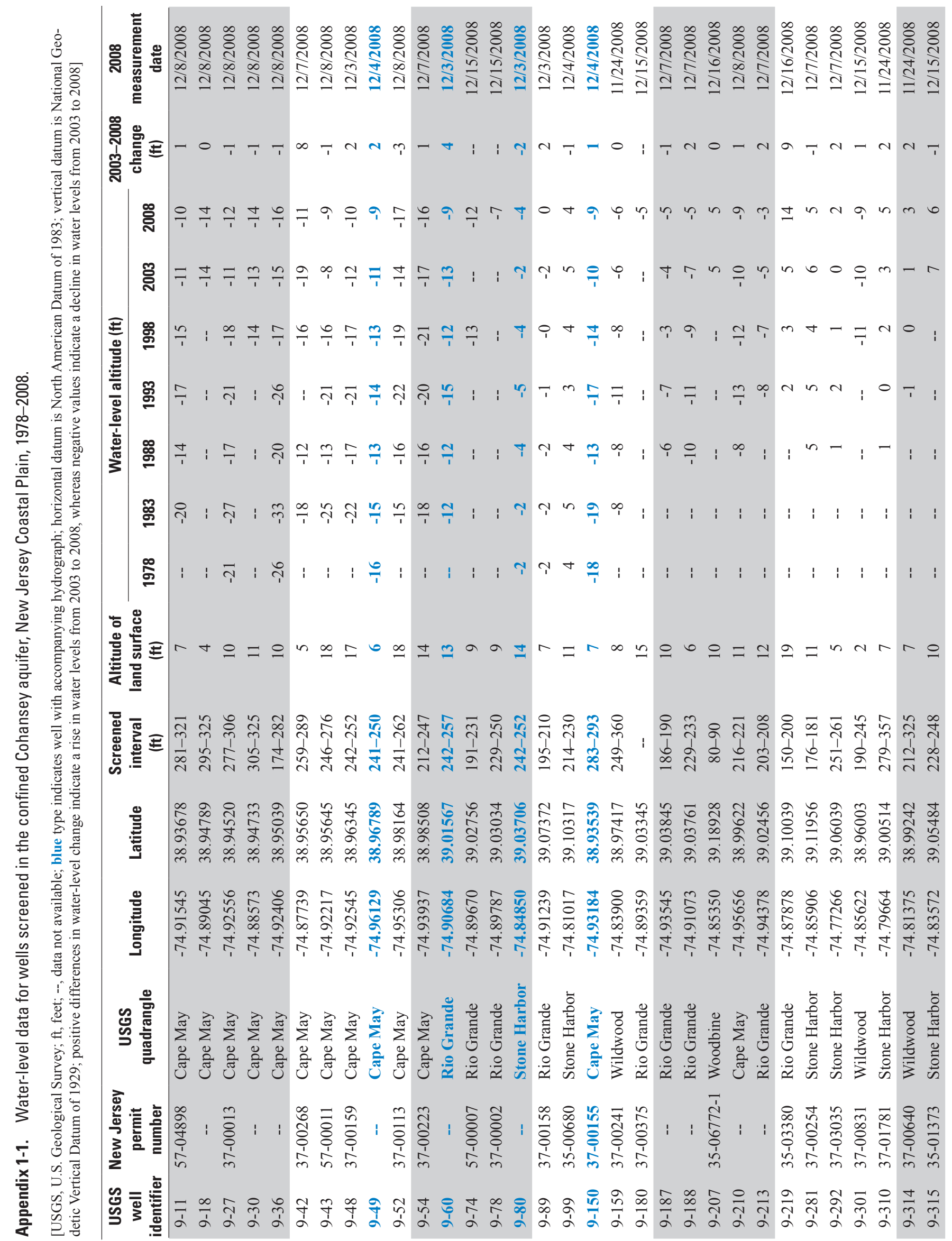



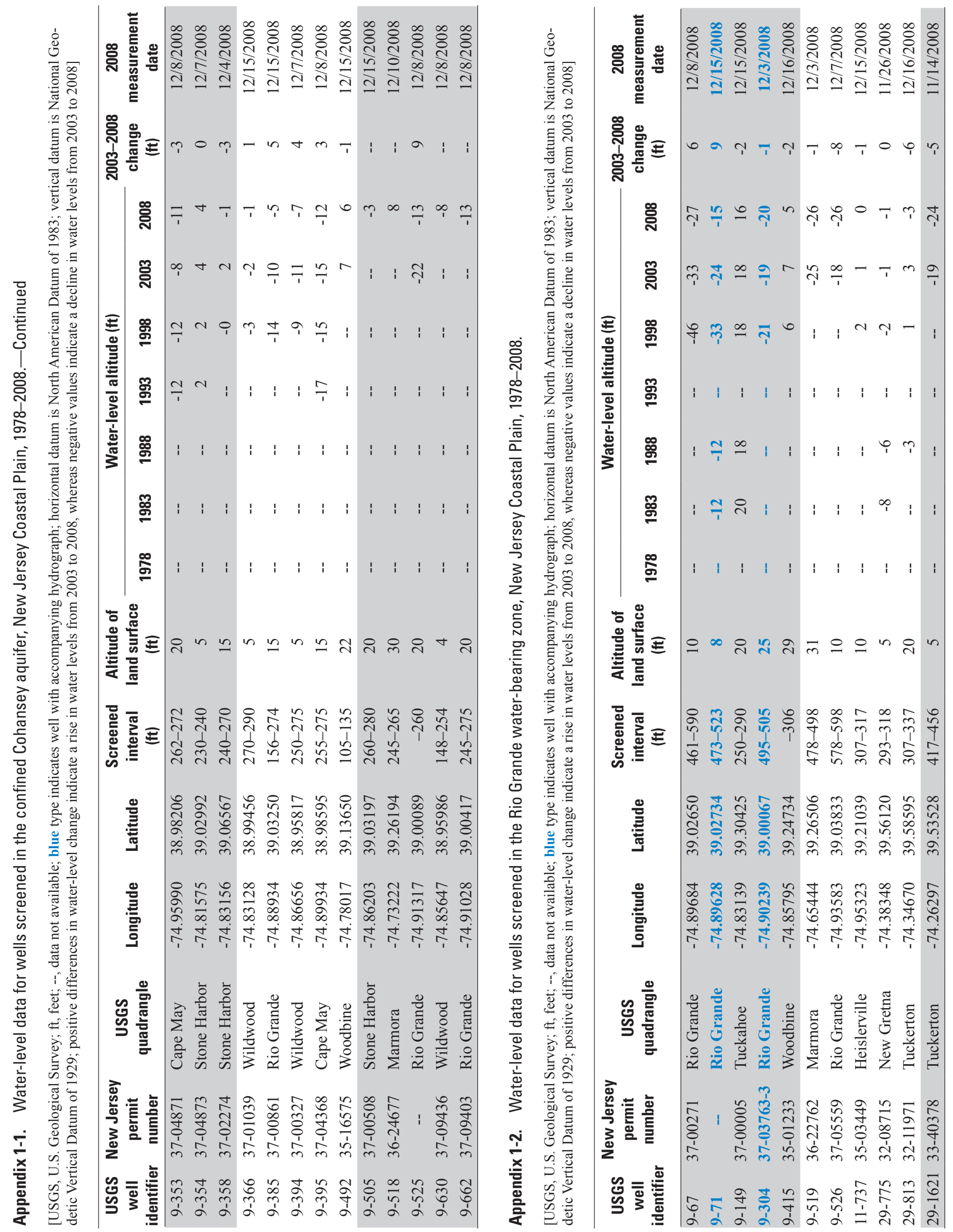


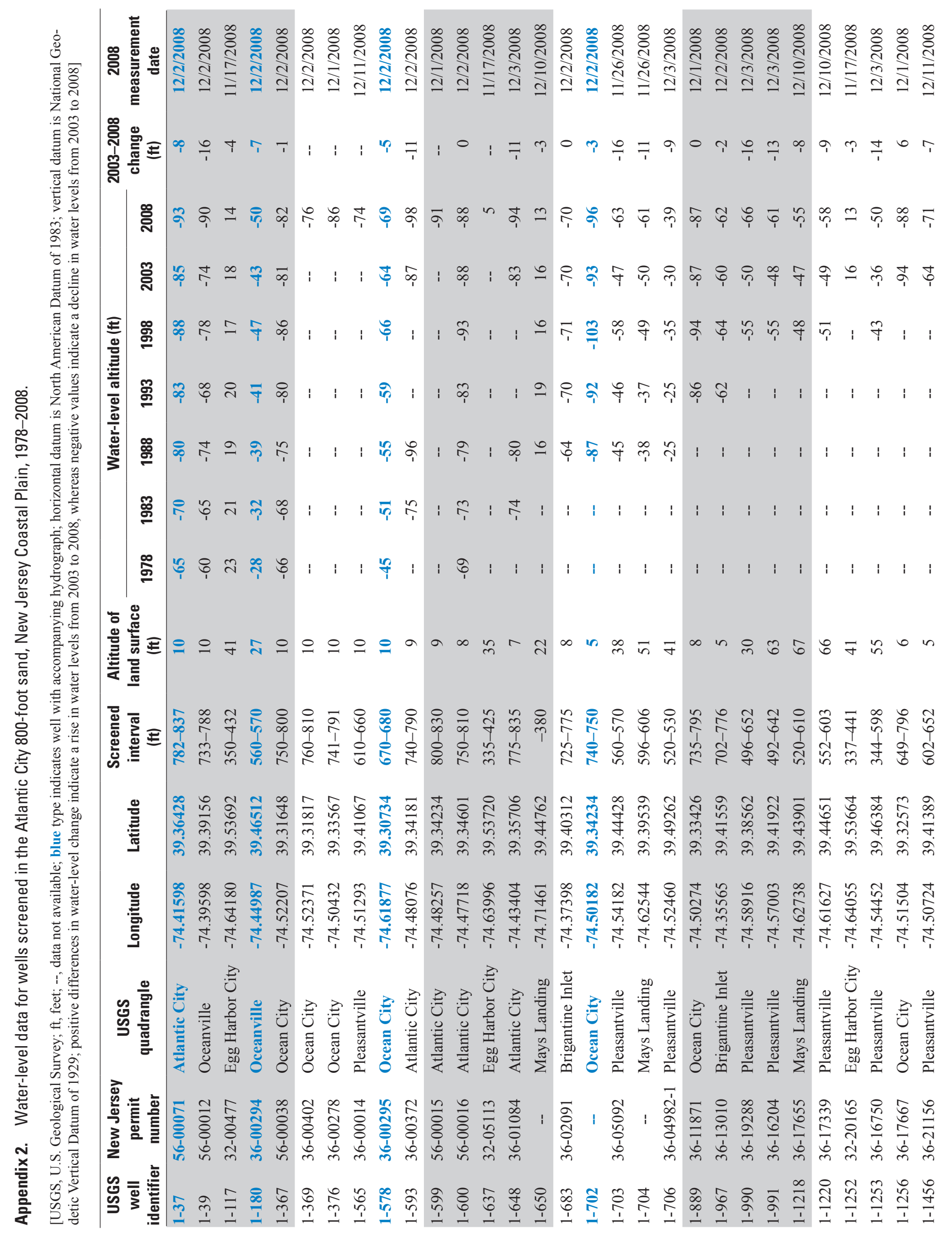




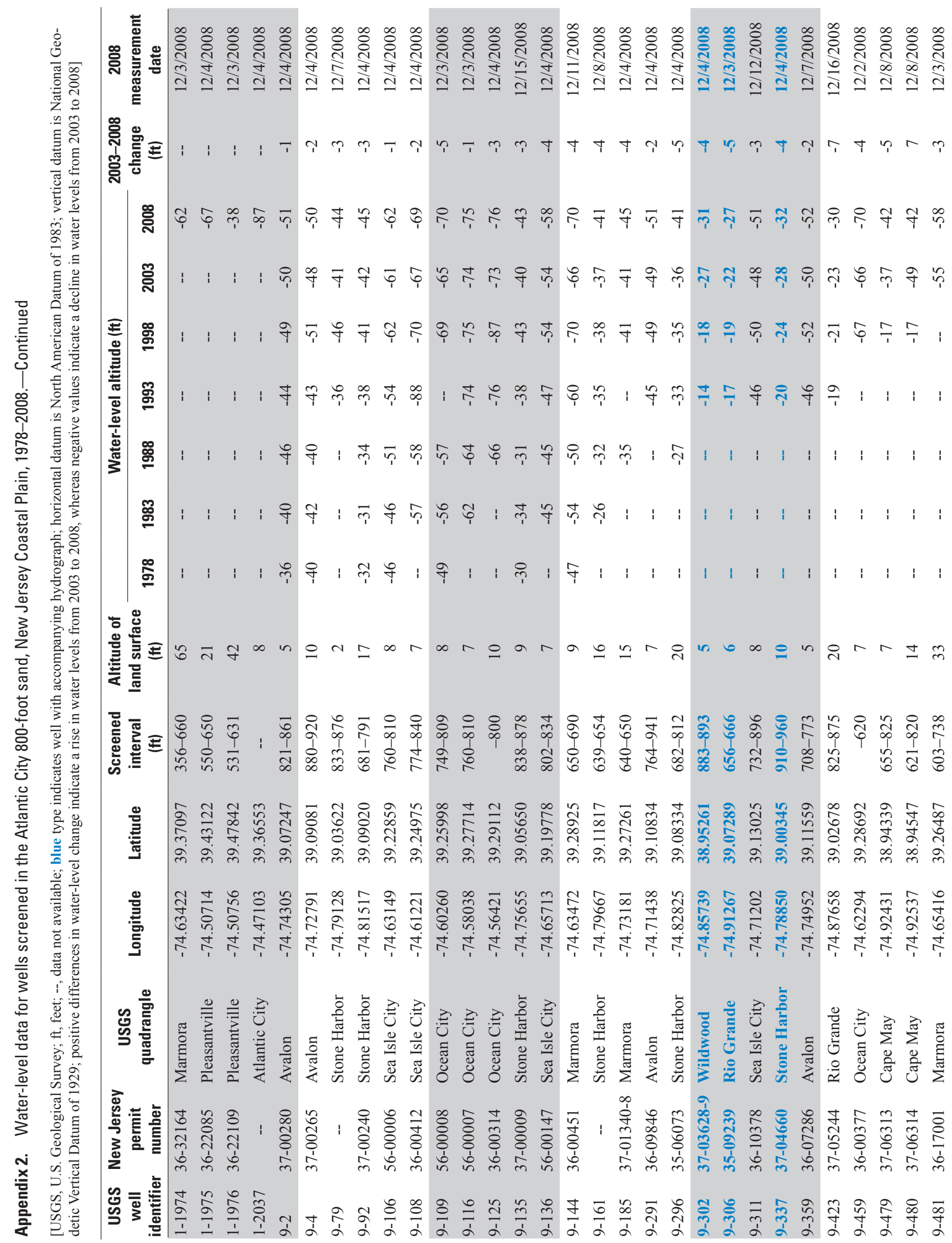




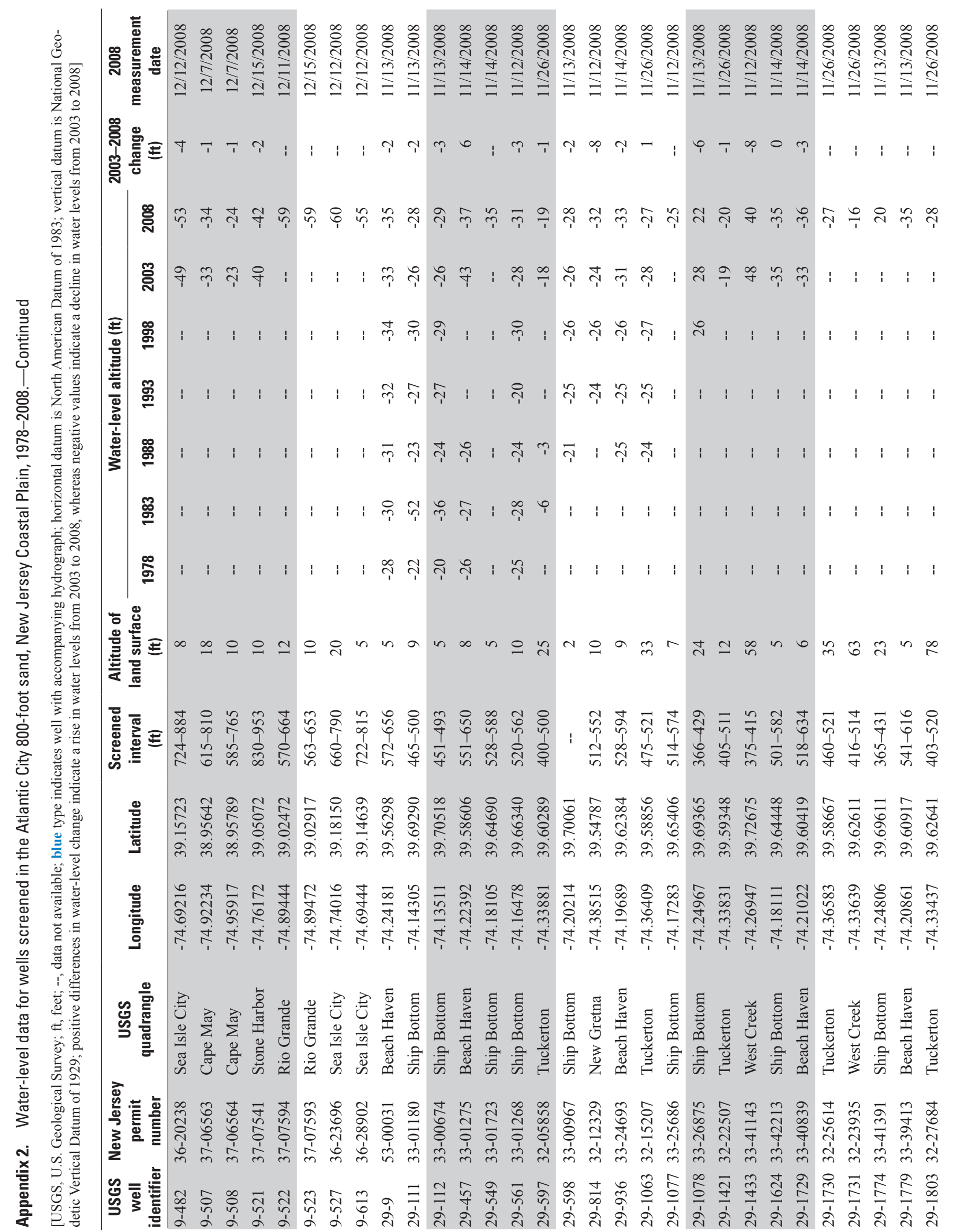




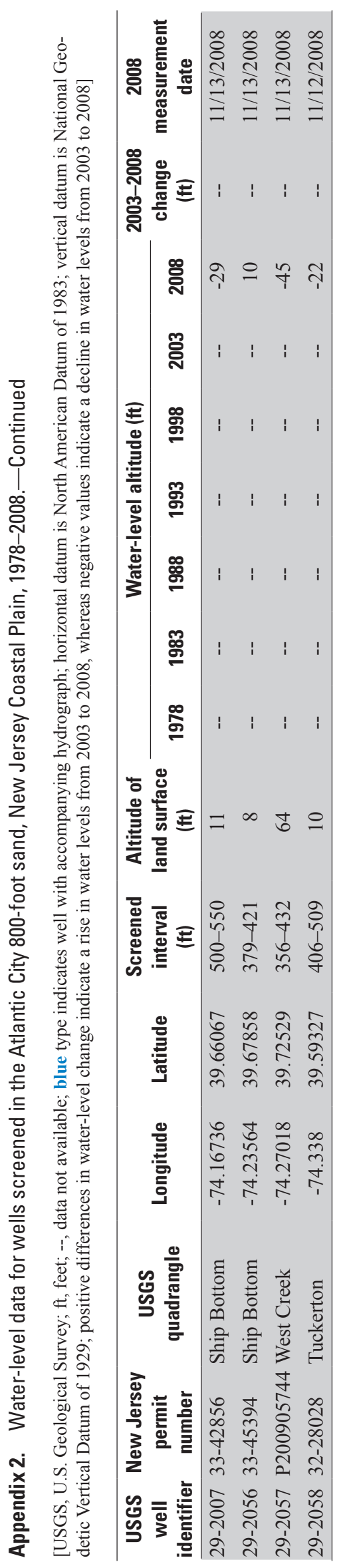




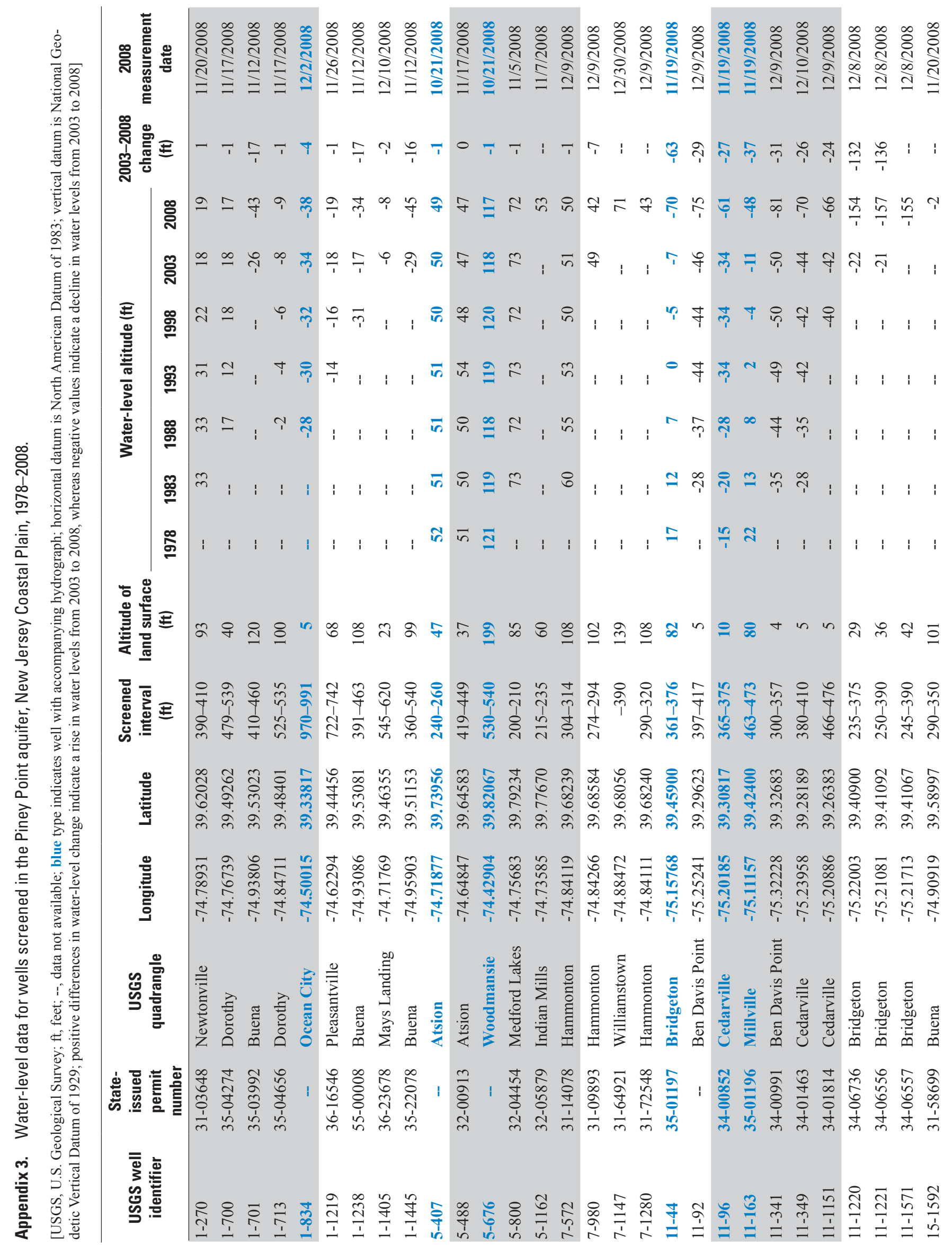




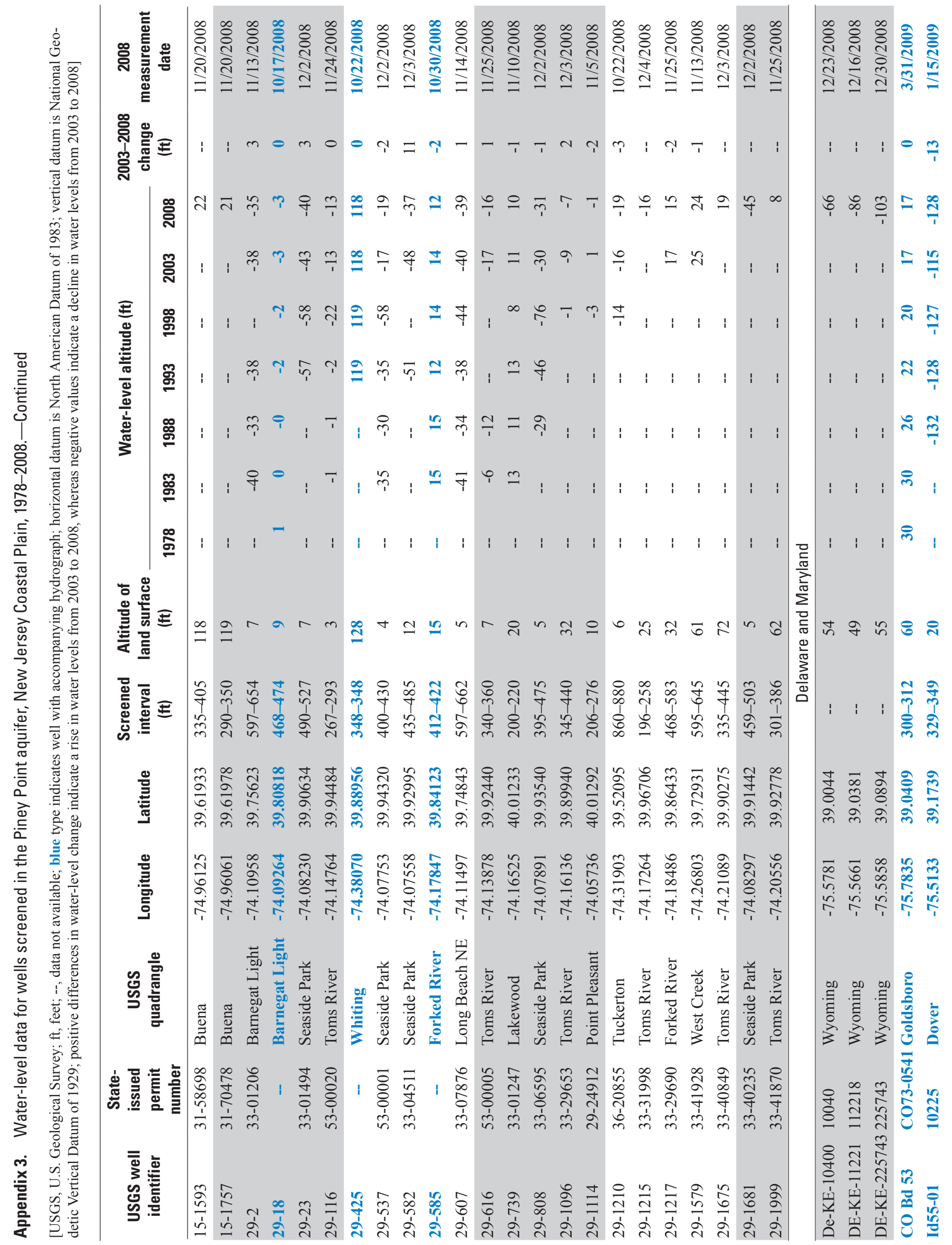




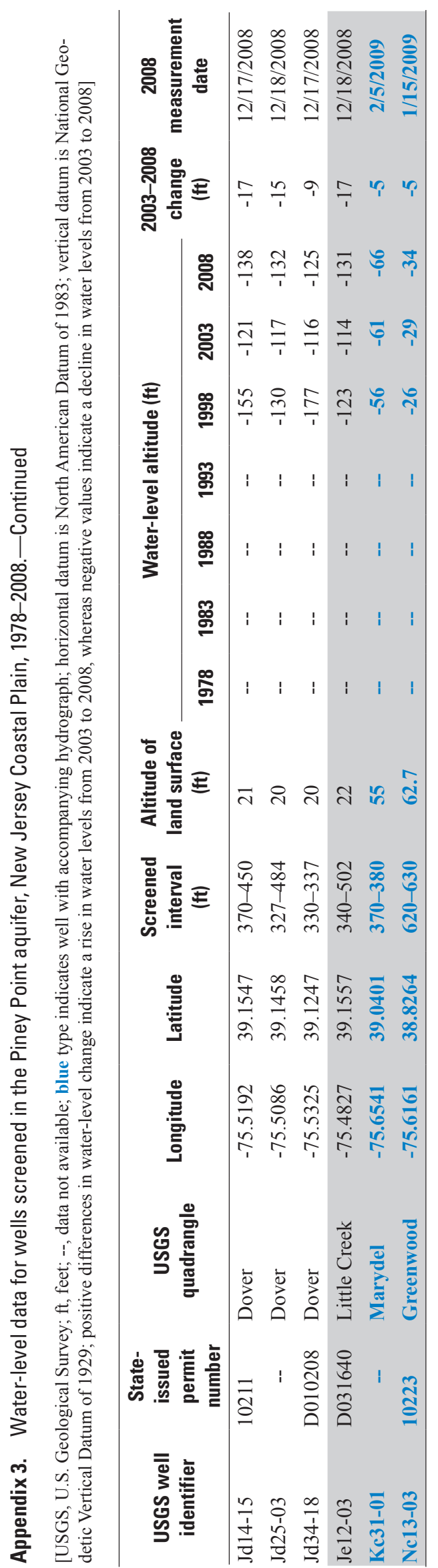




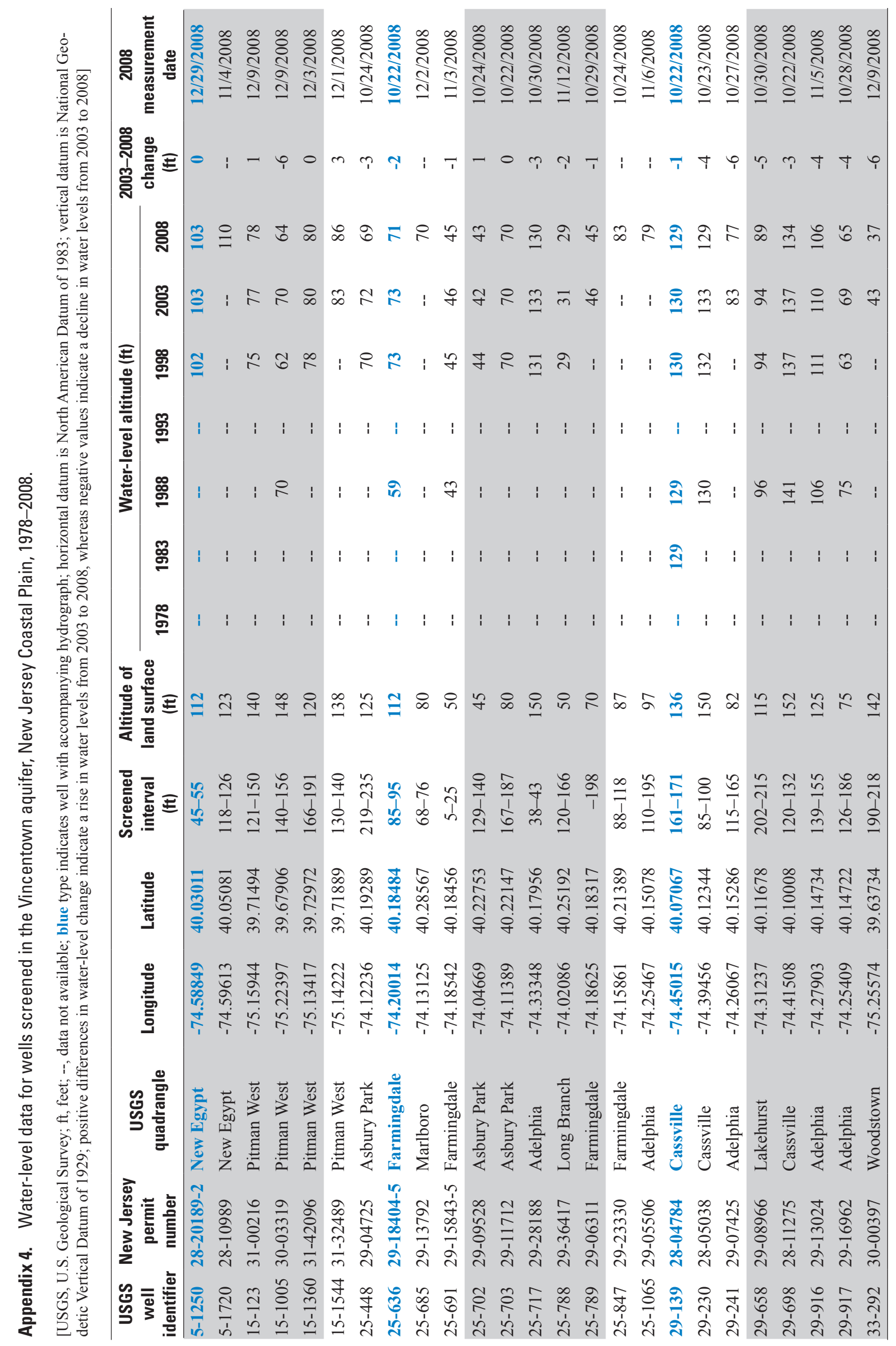




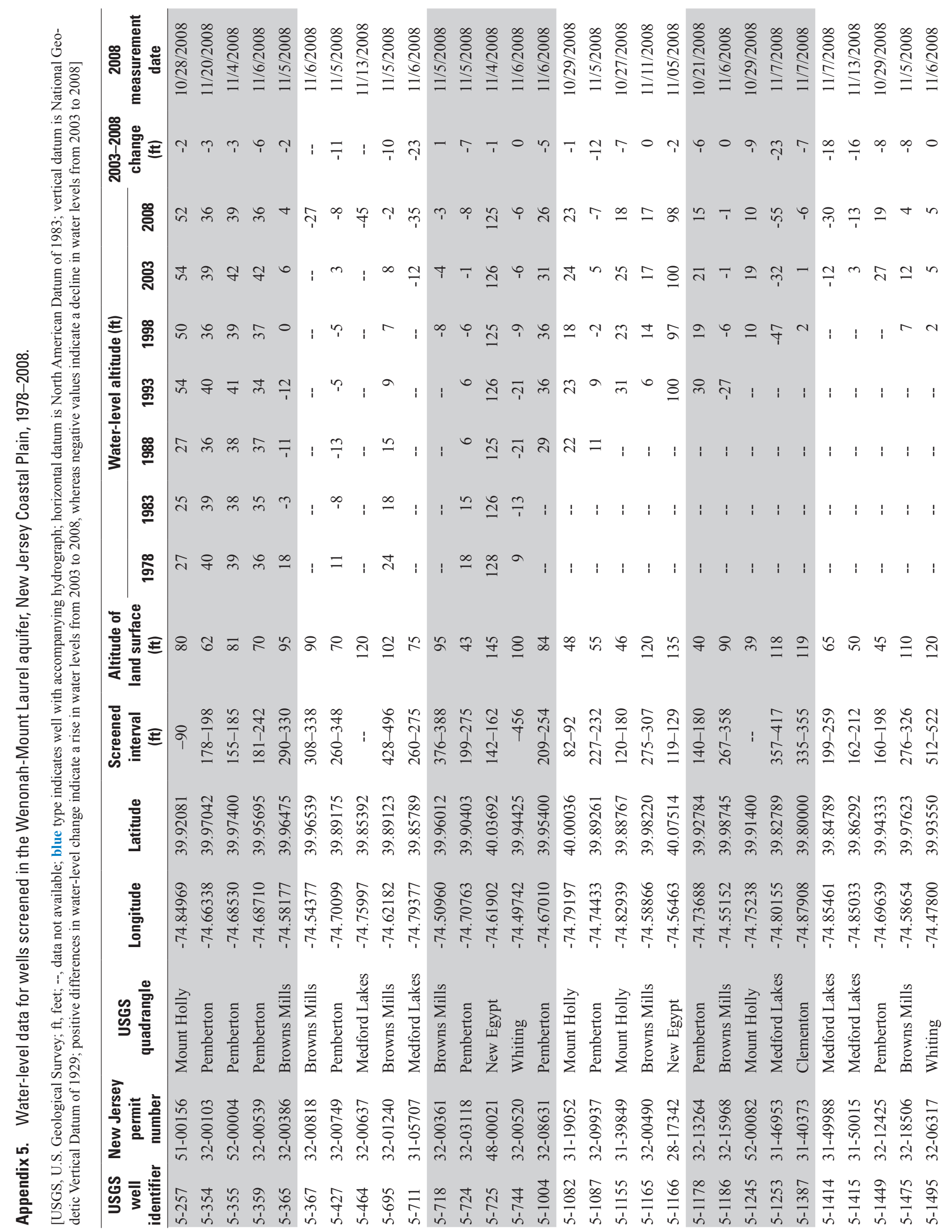




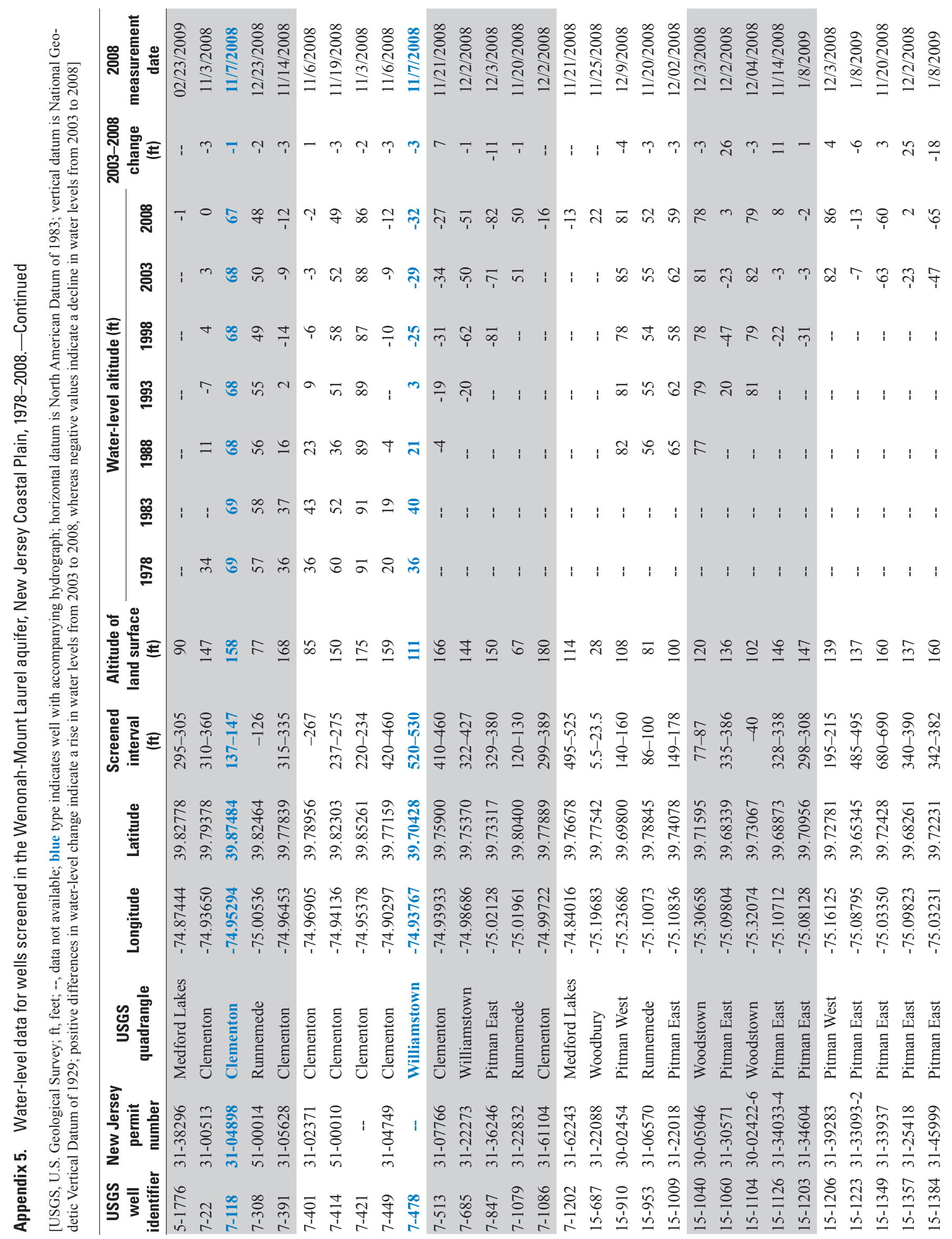




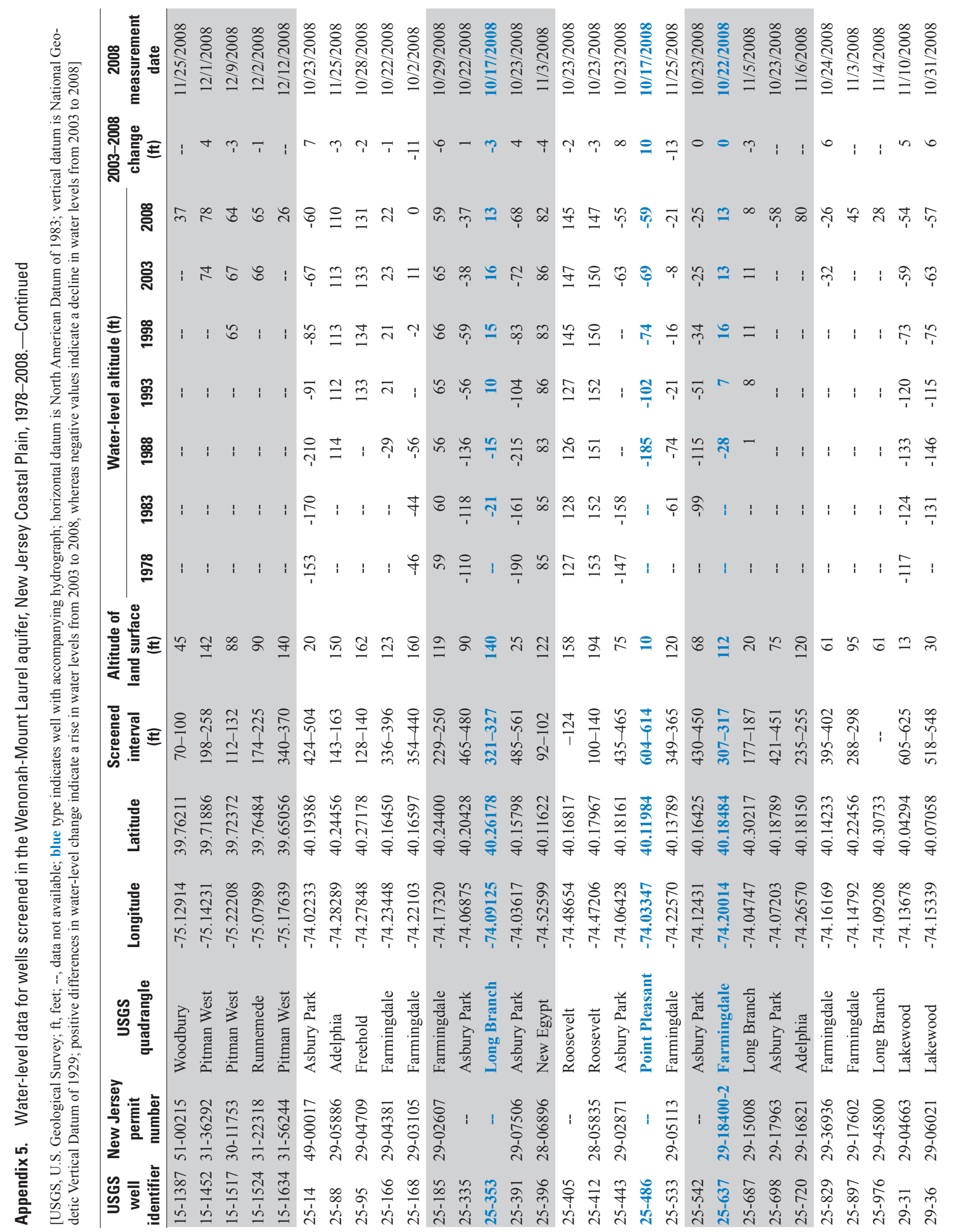




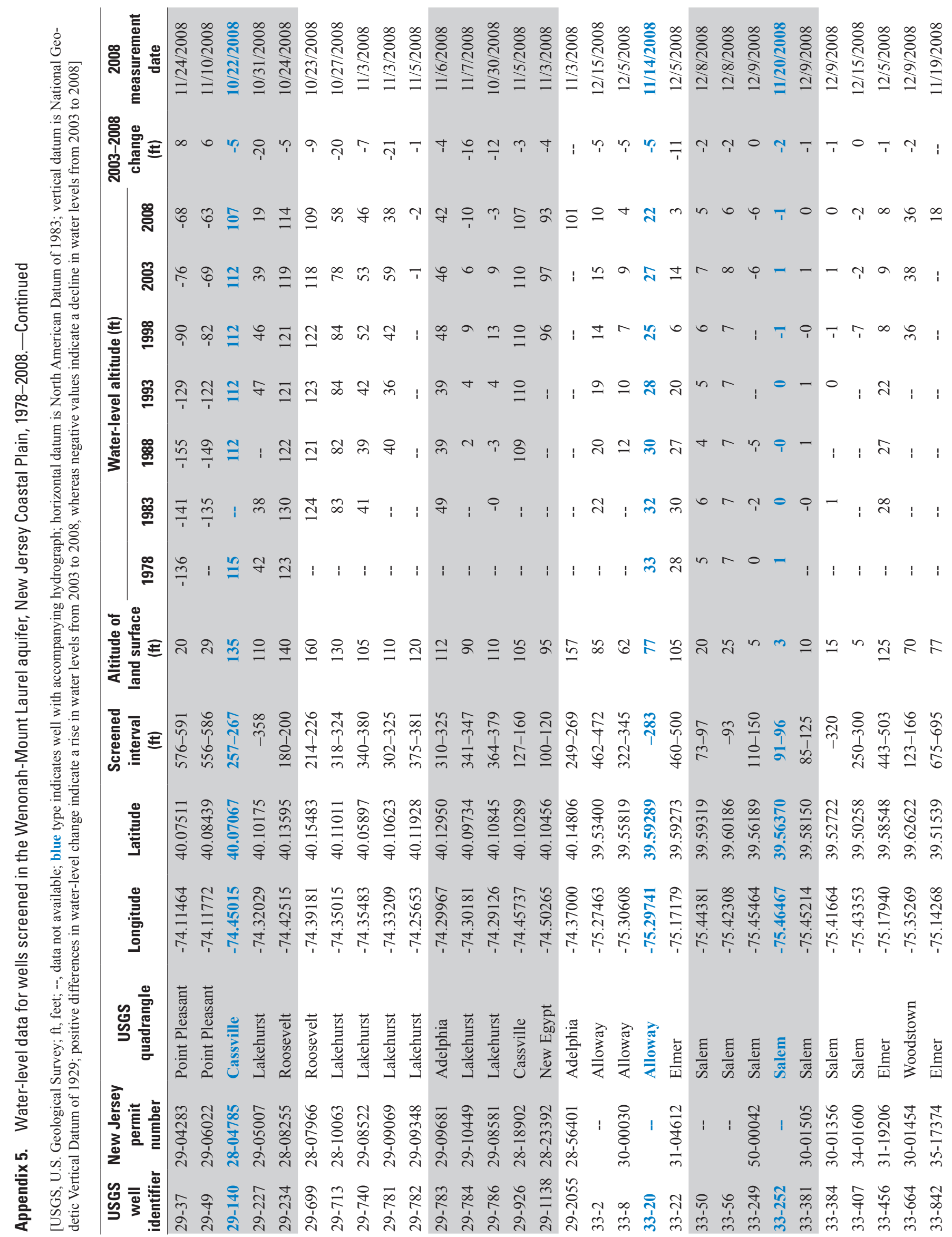




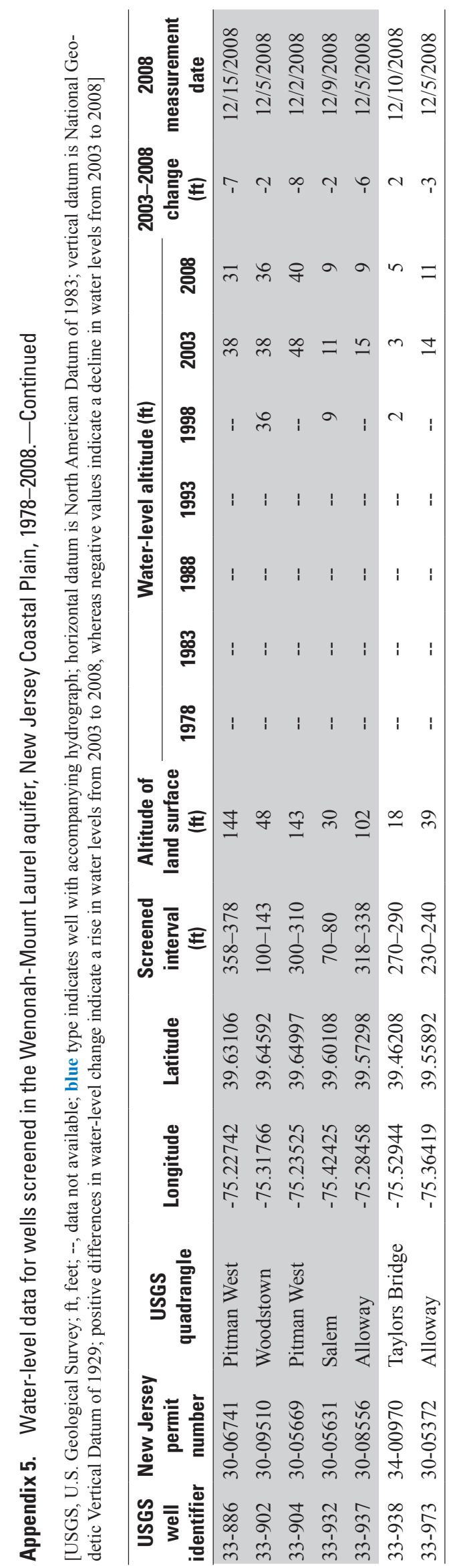




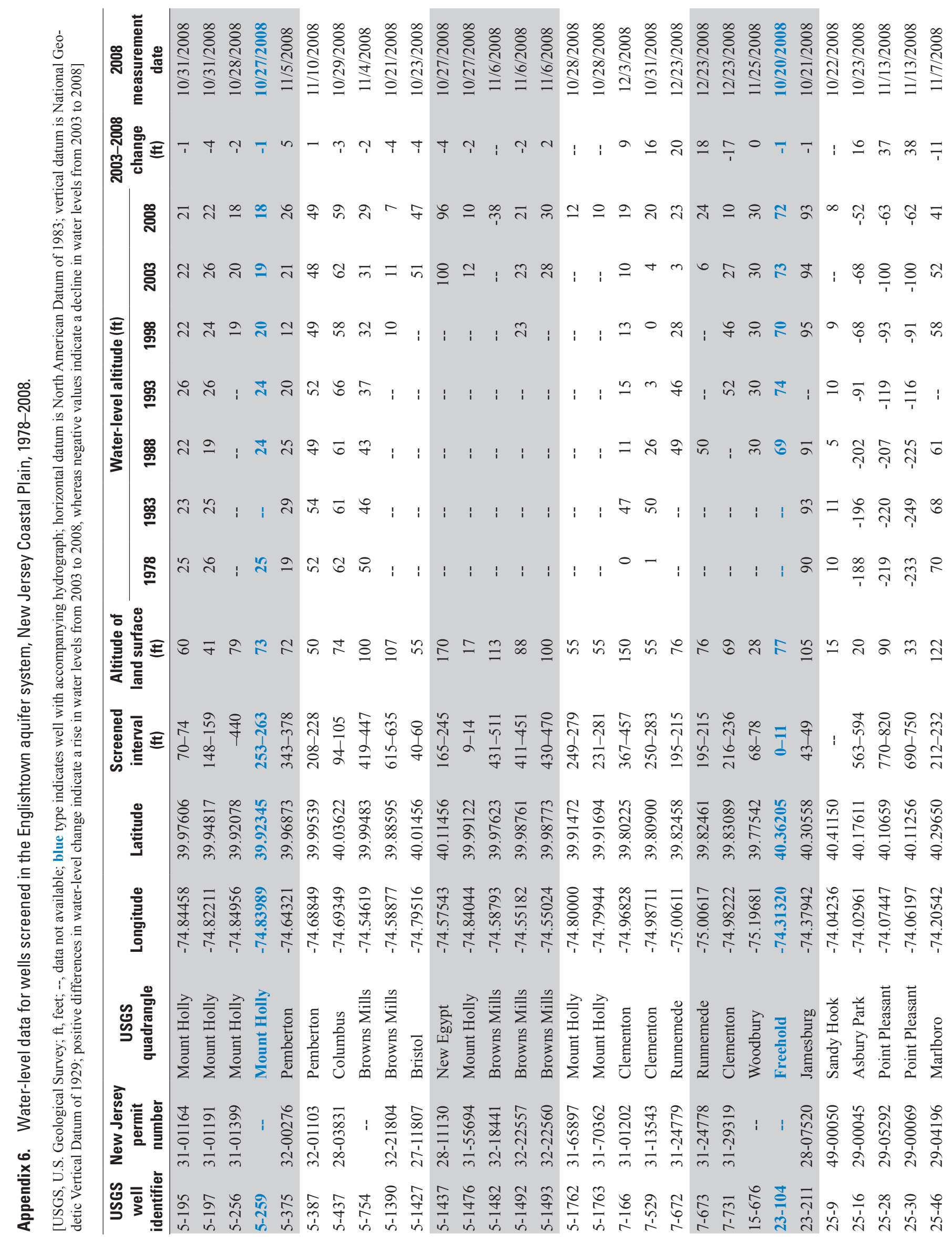




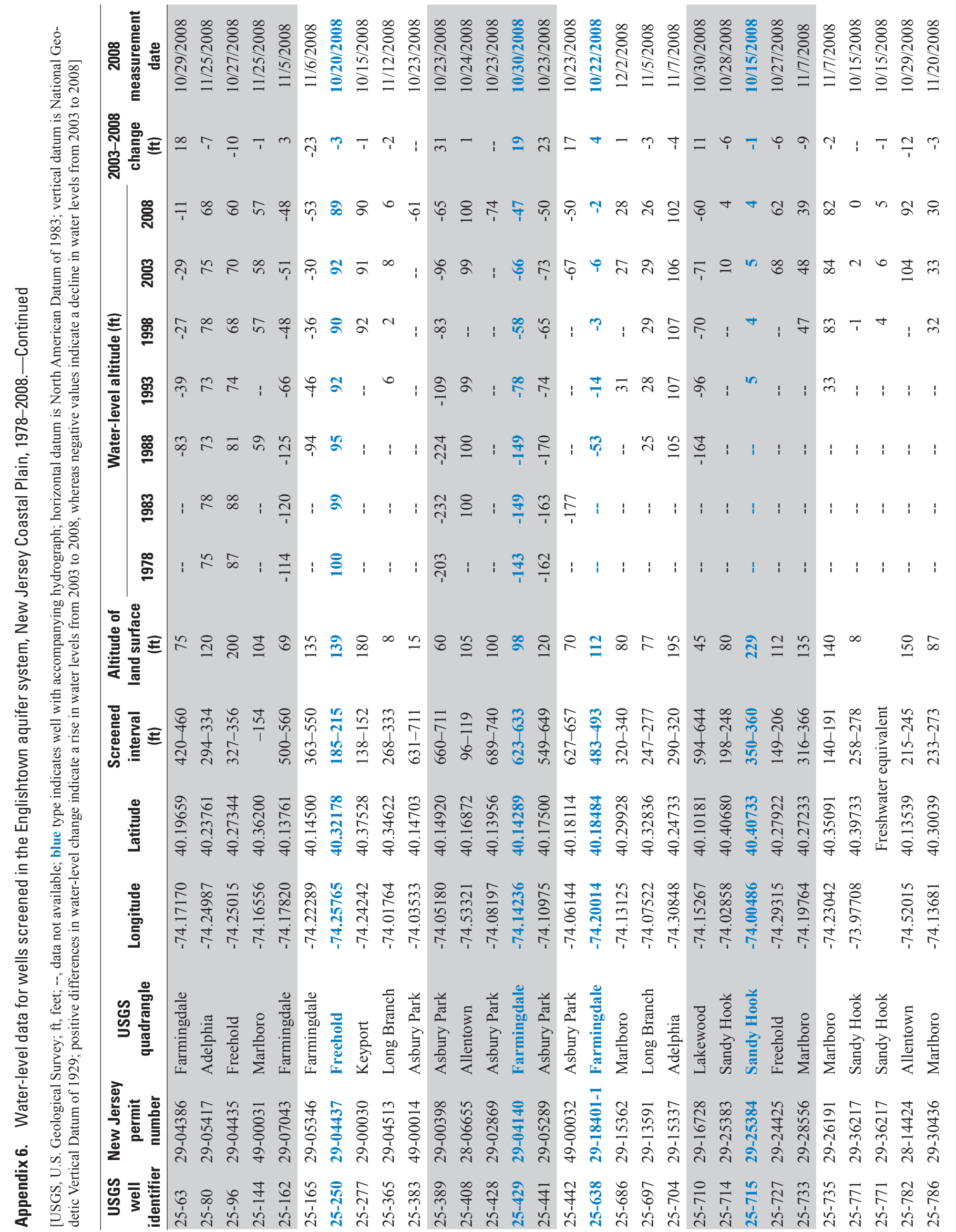




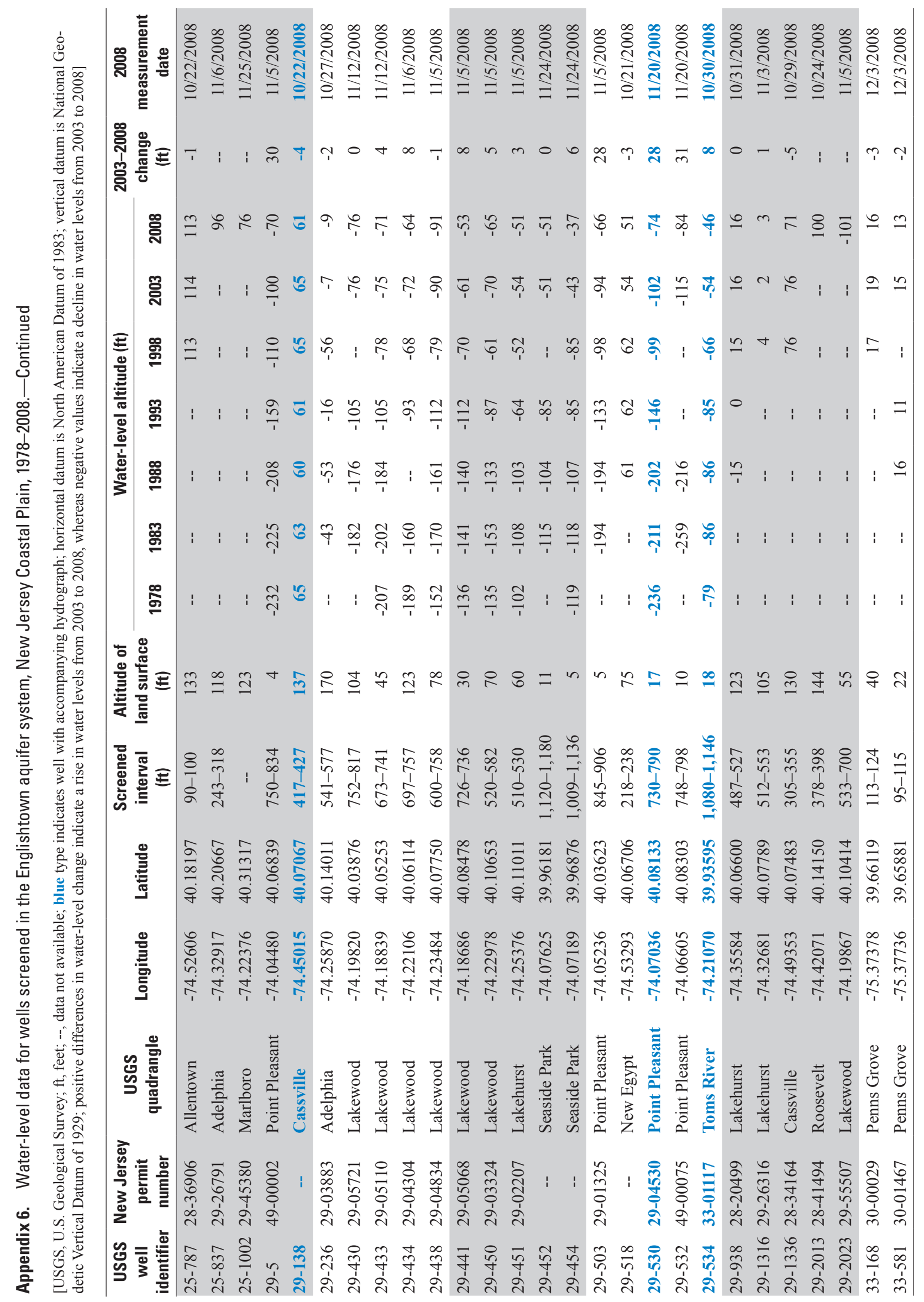




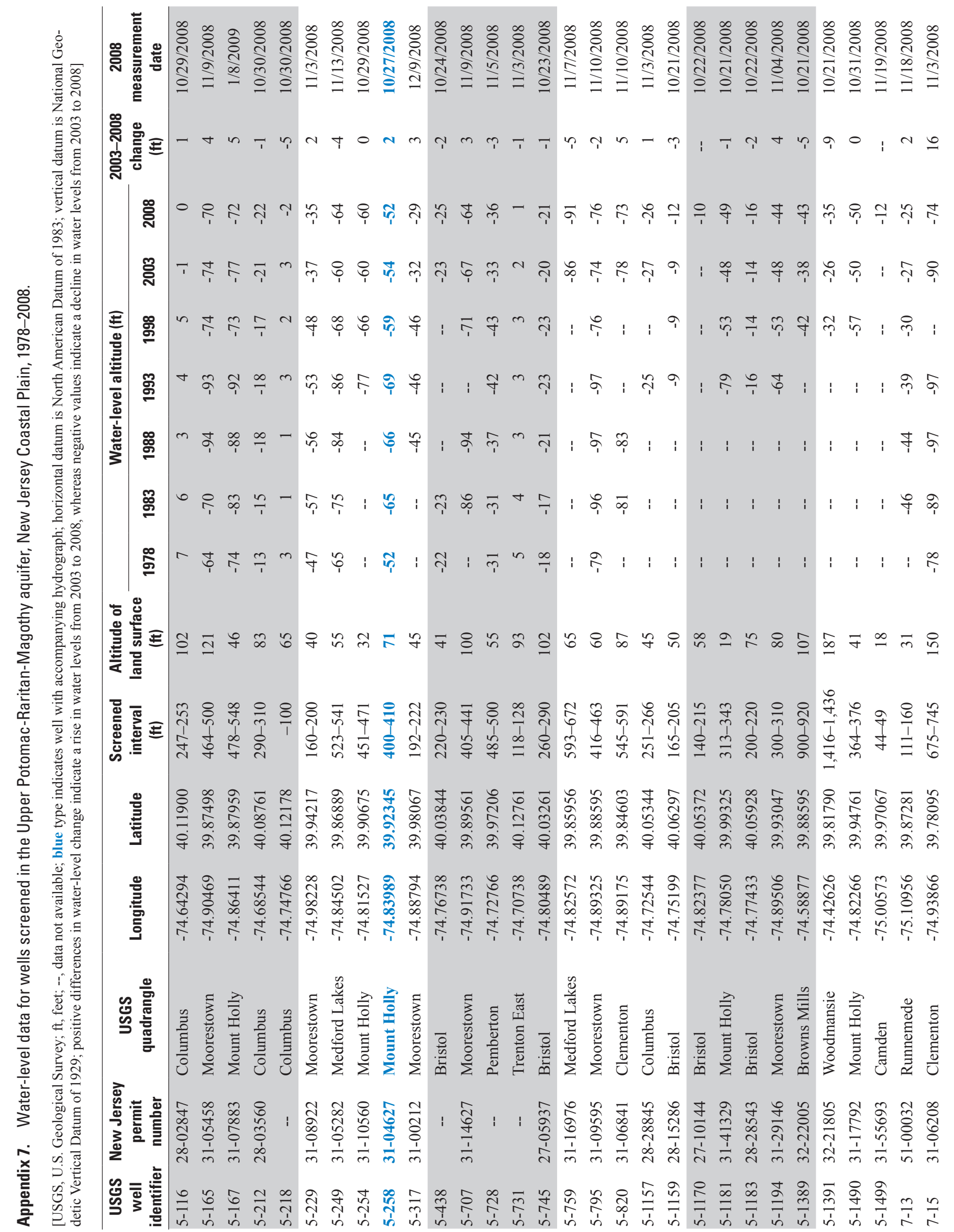


要,

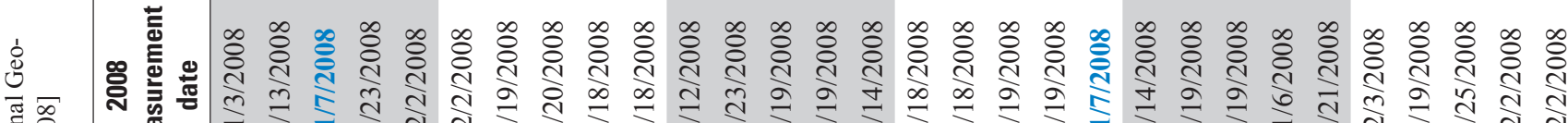

\% 兽

พั่ 薃

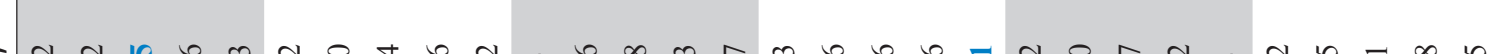

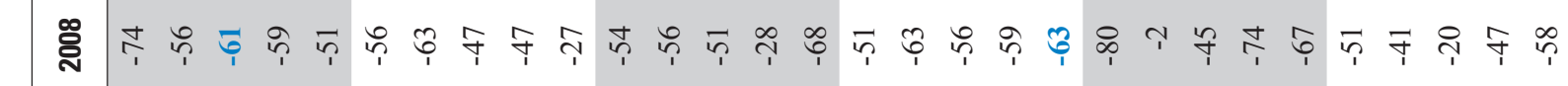
苛

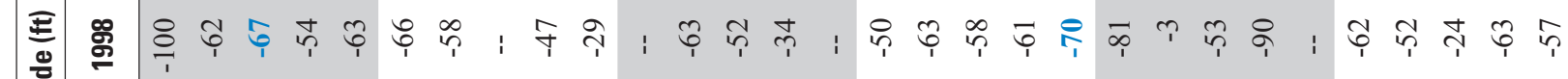

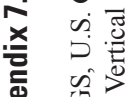

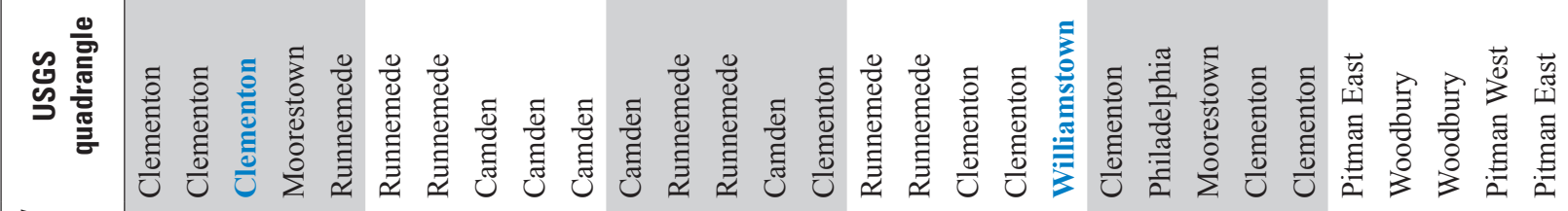




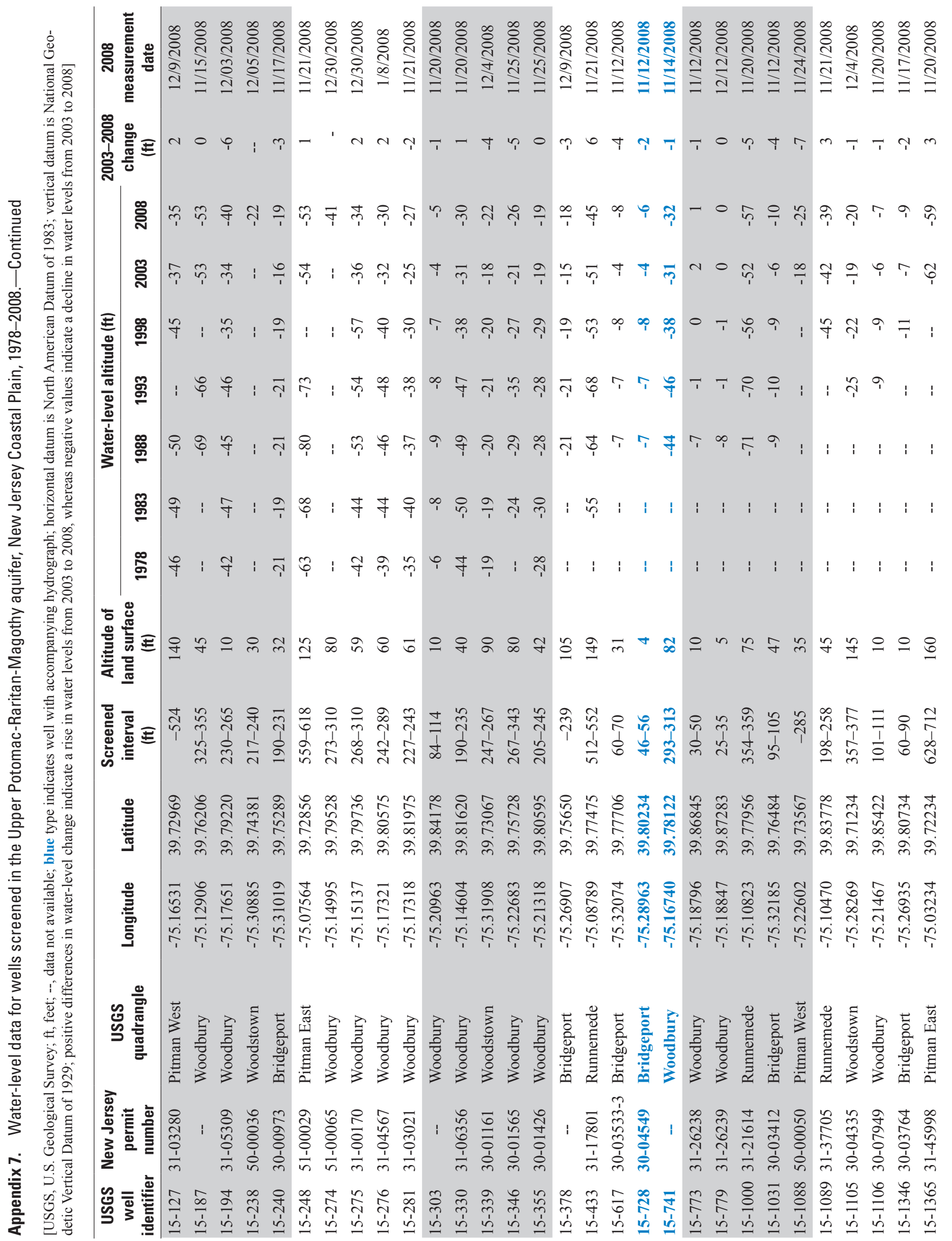




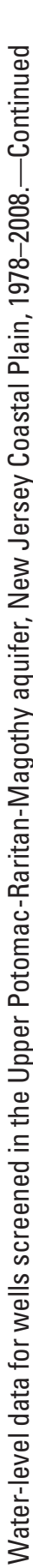

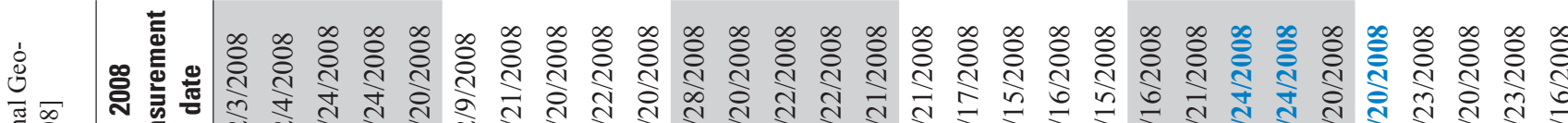

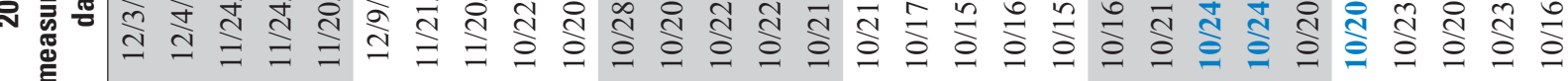

\%

里

뜽

氖

容

ळ

苟

:

象

荅

窇

之े

寻骂

每

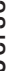

믕

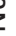

50

을

育

-

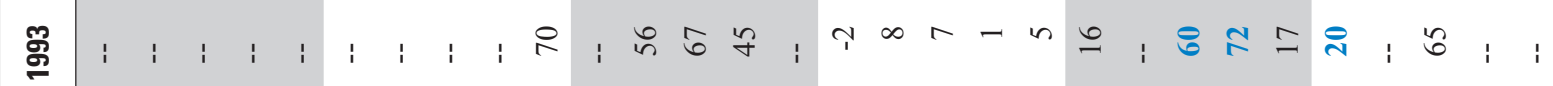

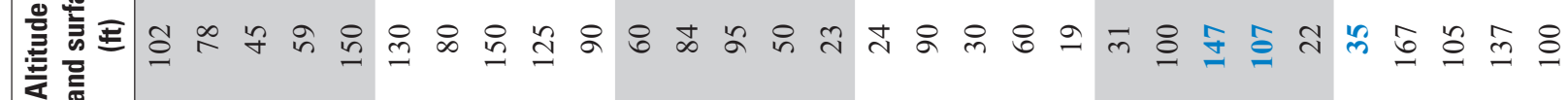

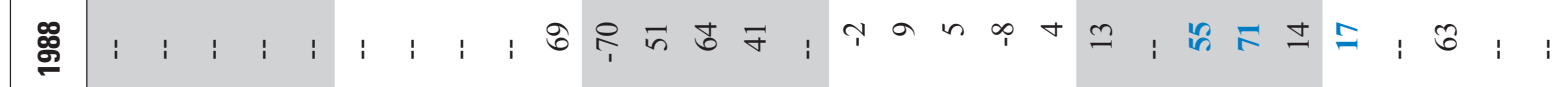

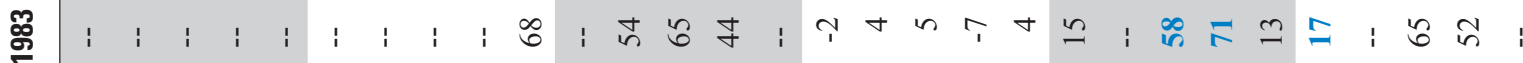

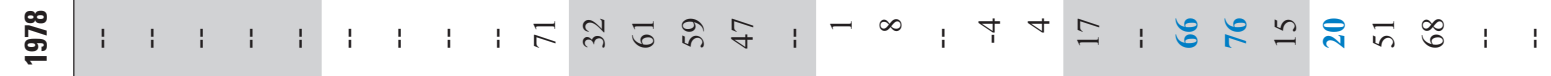

石

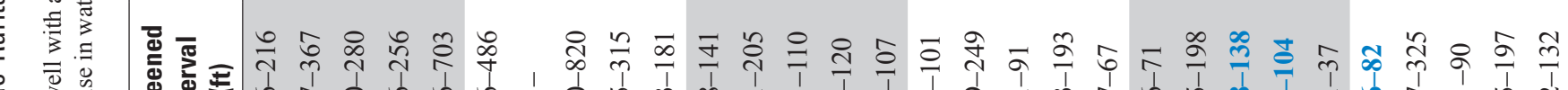

(5)

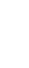
峛.

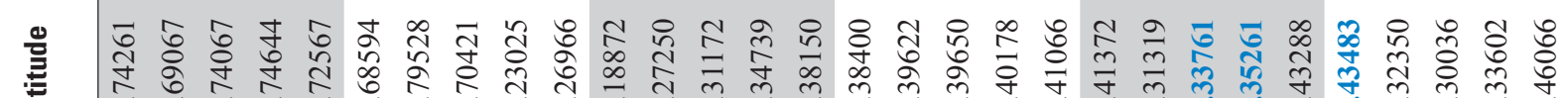

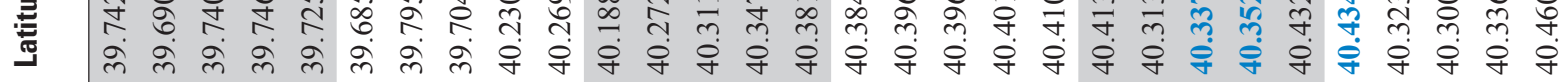

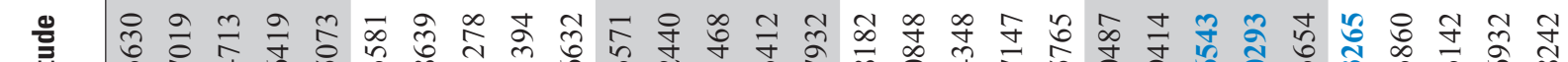

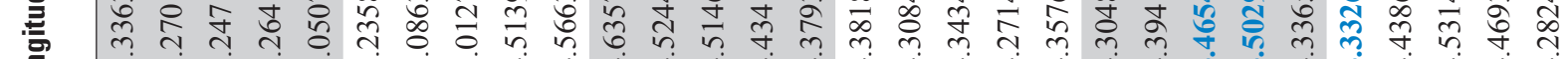

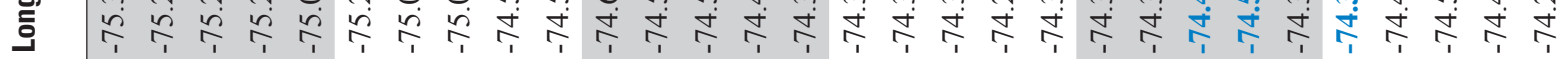

\section{政}

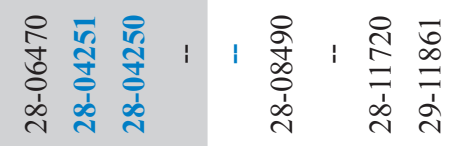




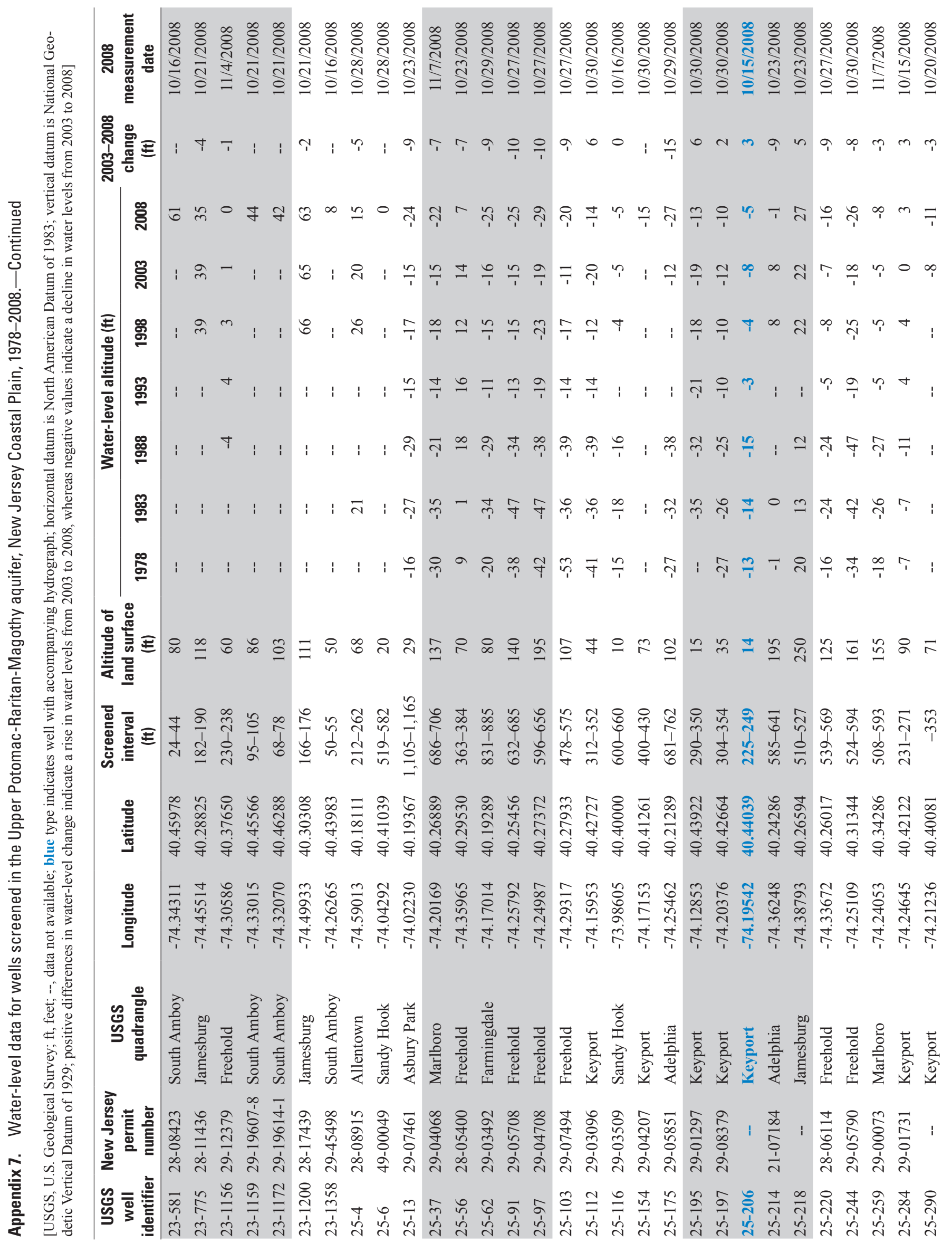




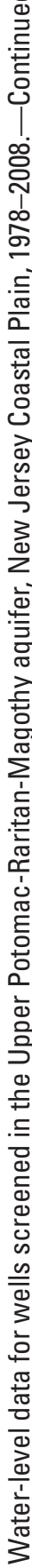

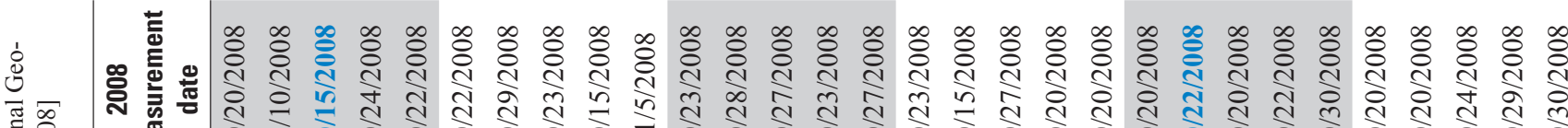

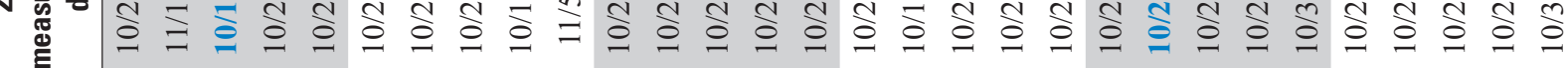

\%

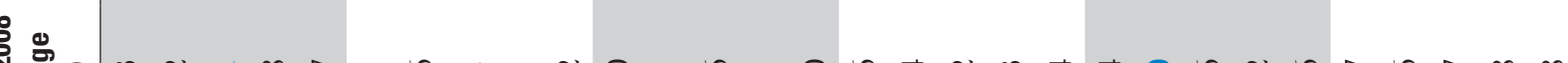

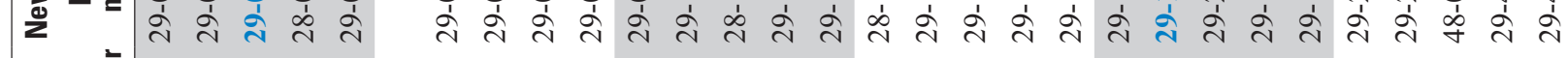

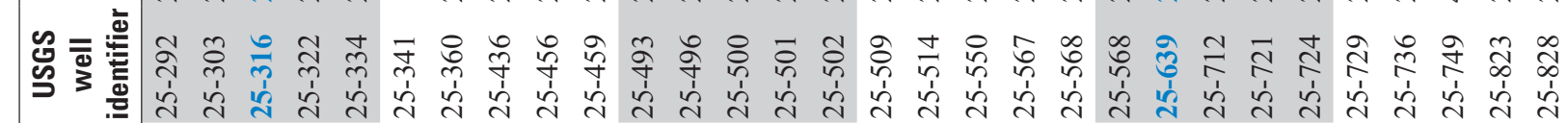




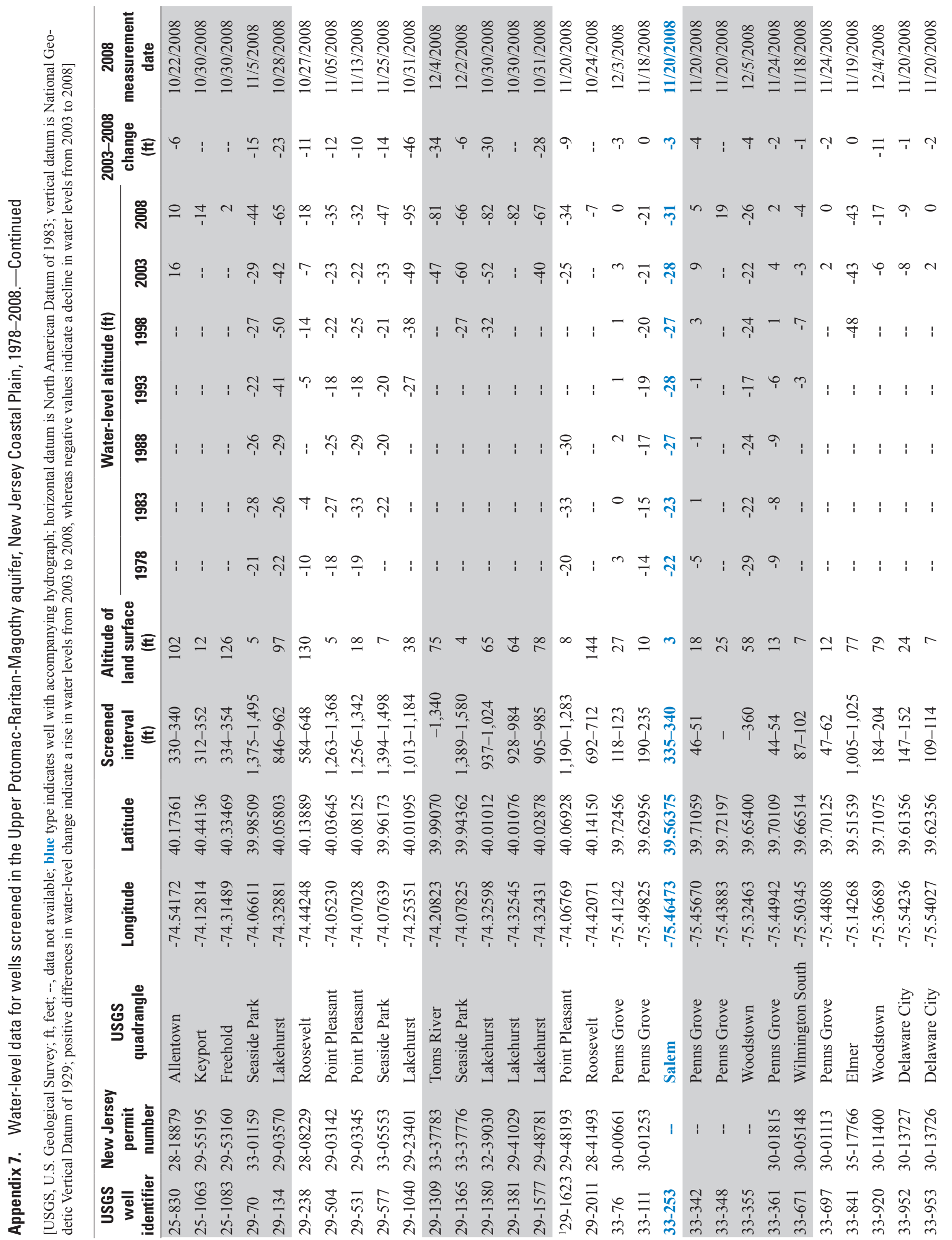




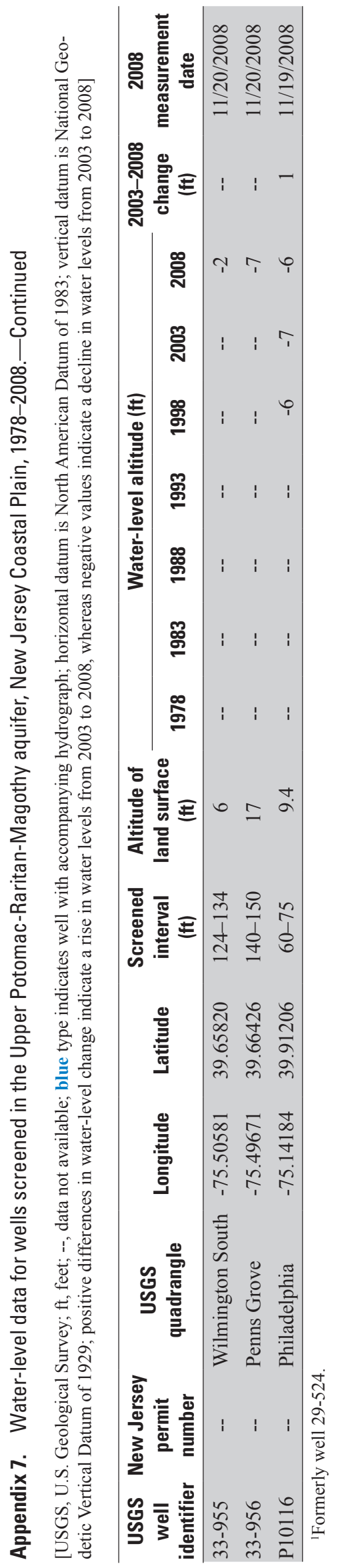




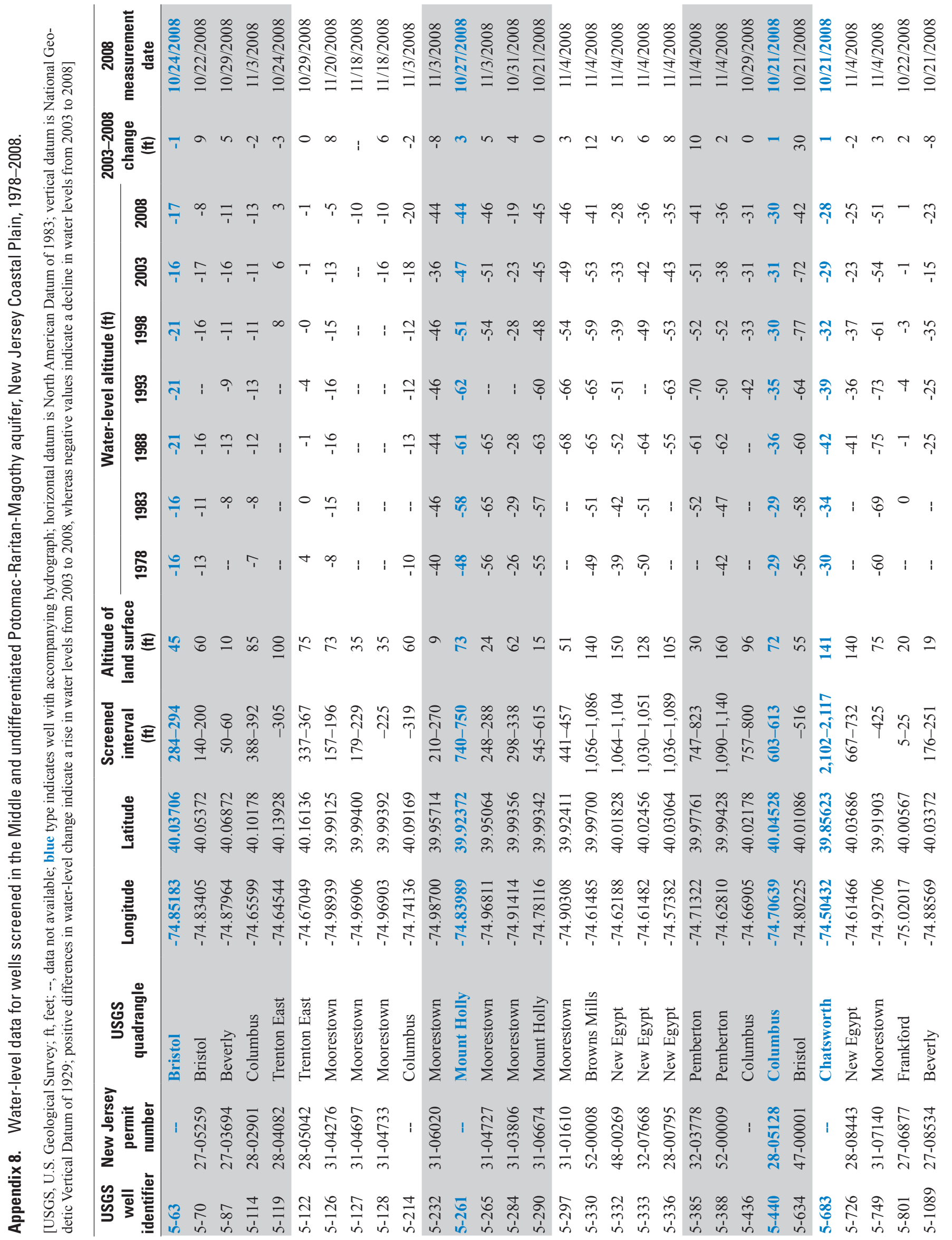




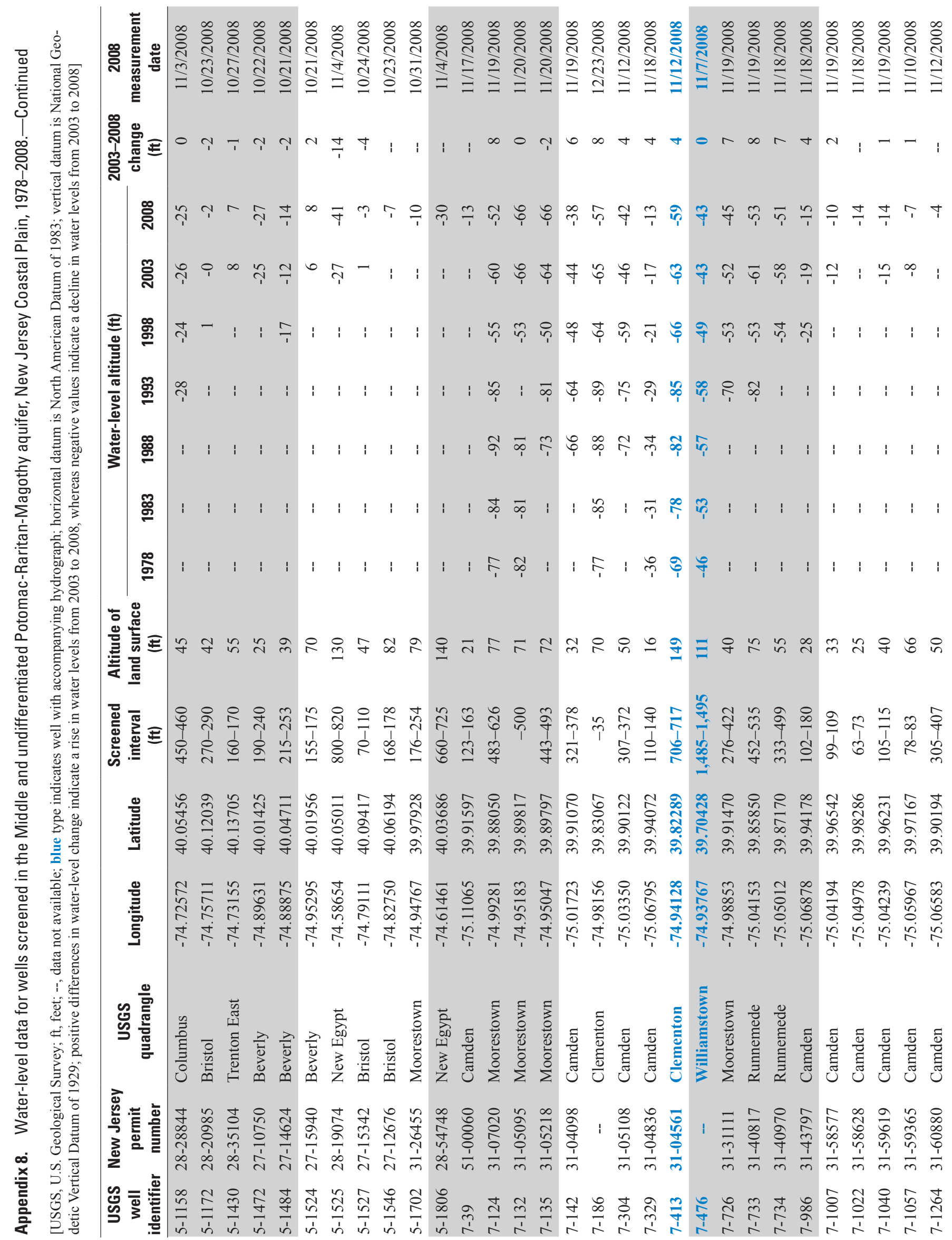




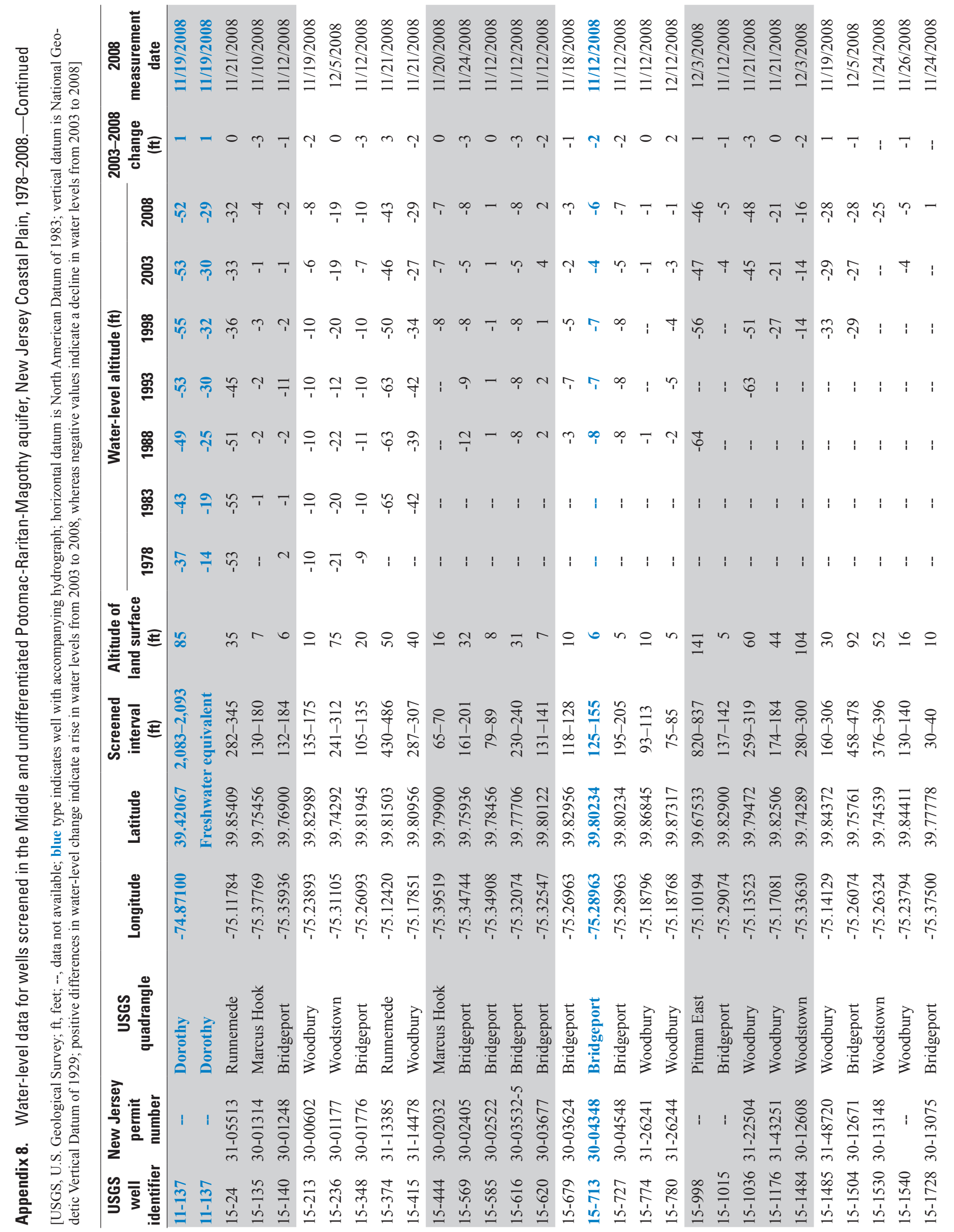




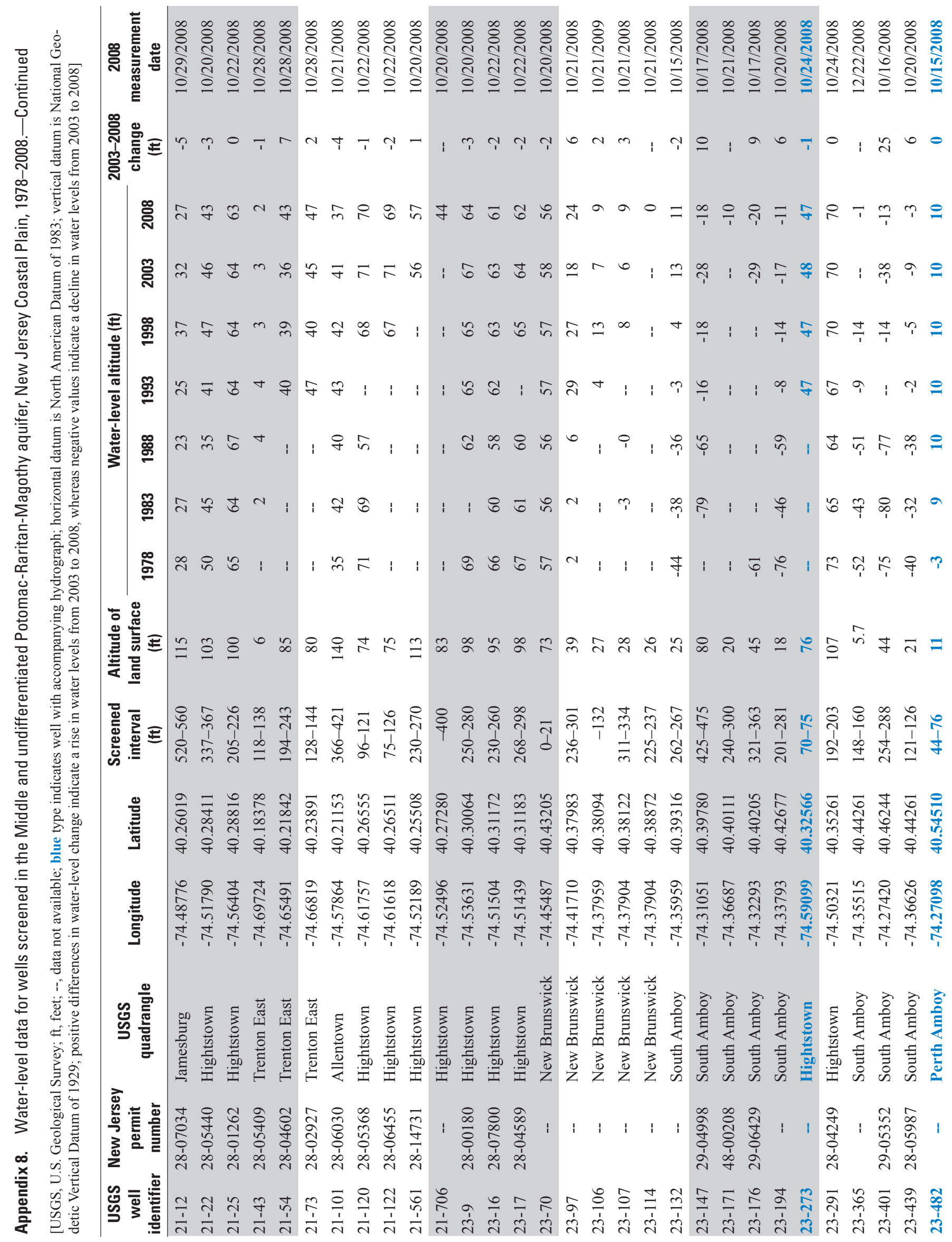




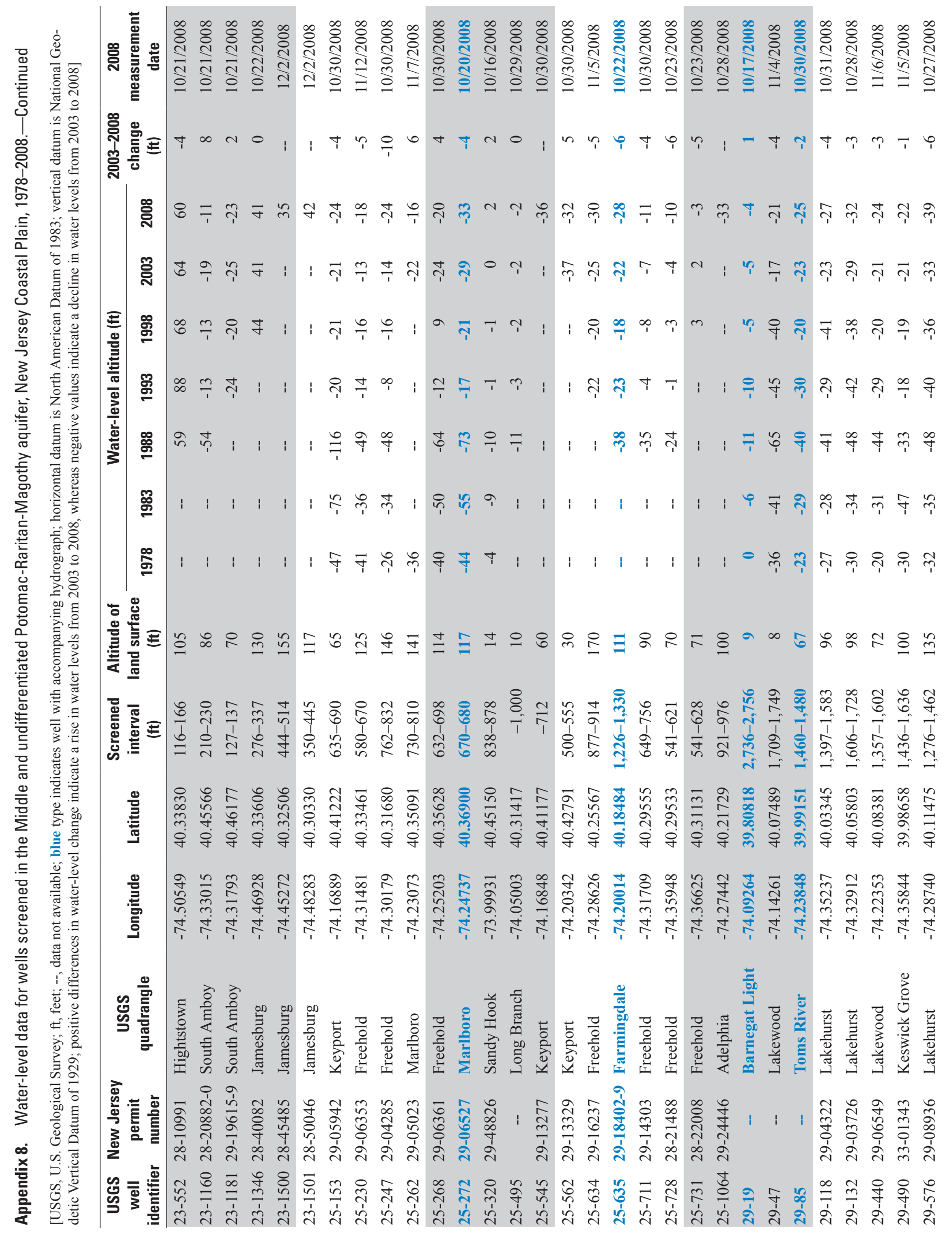




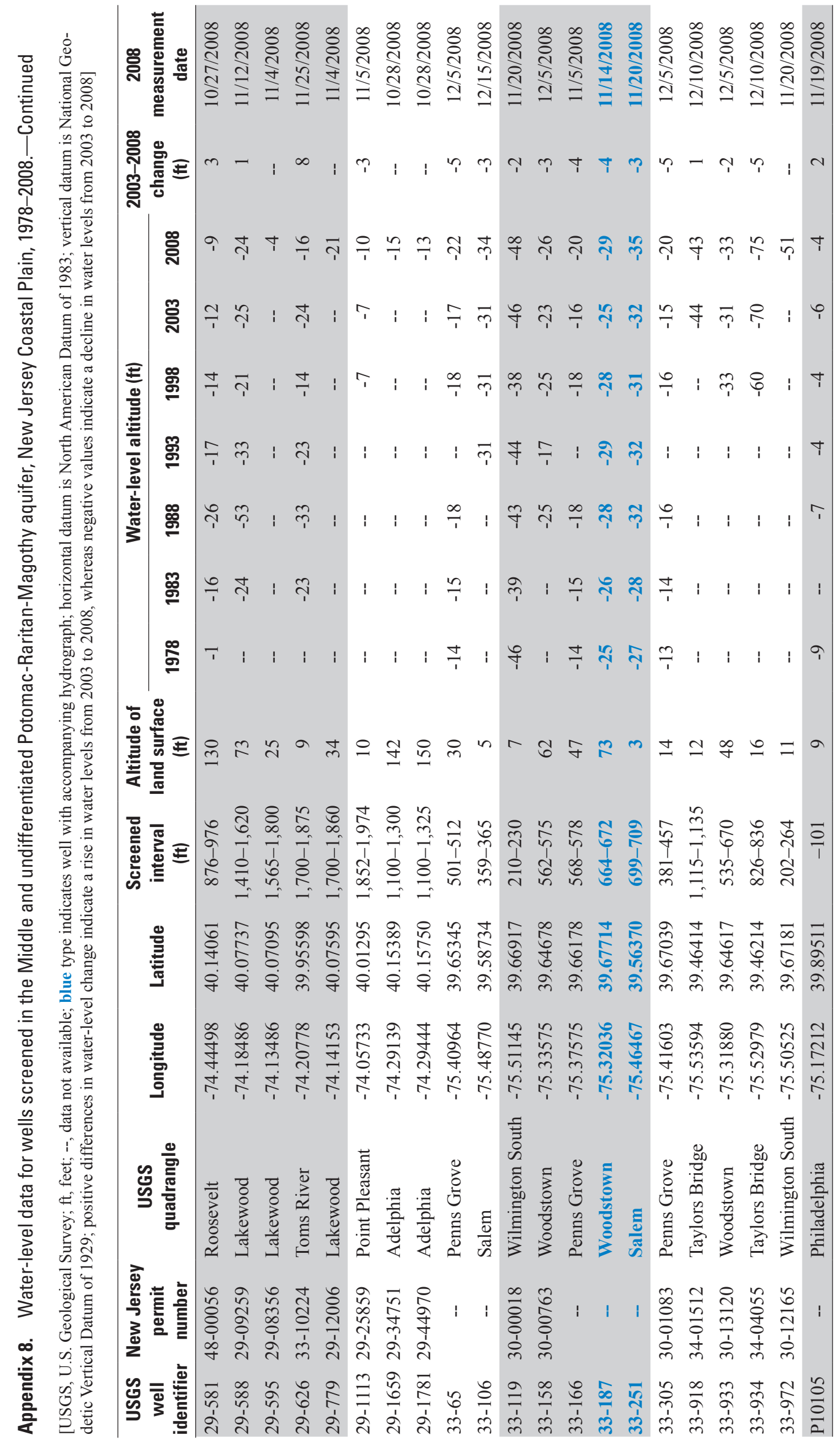




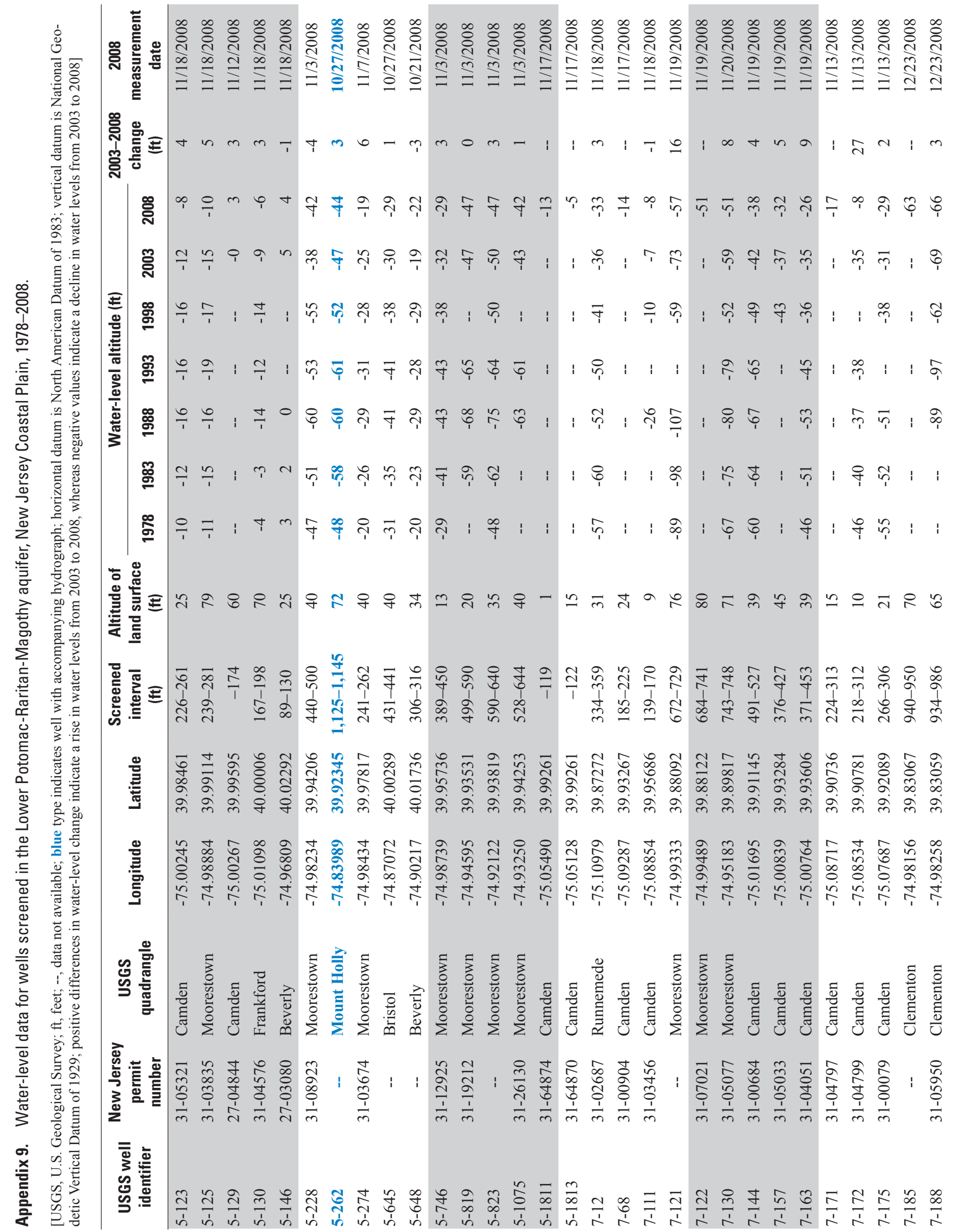




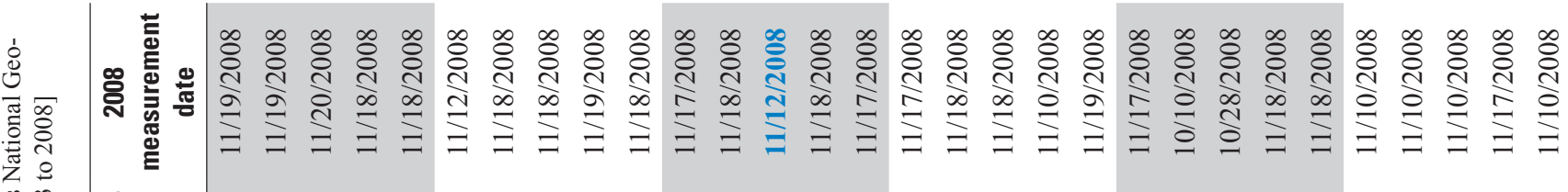

ㅇํํ 


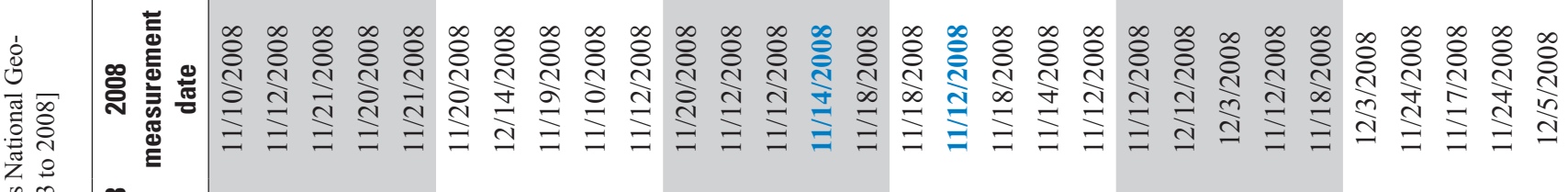

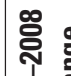

帚

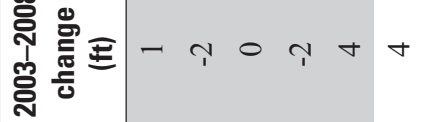

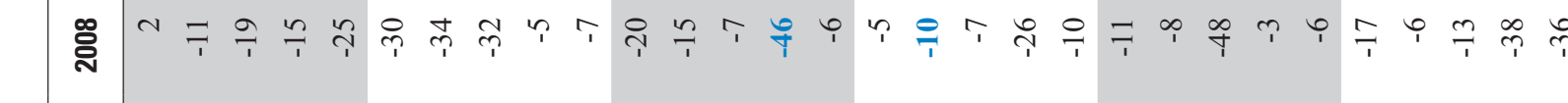

กิ้ -

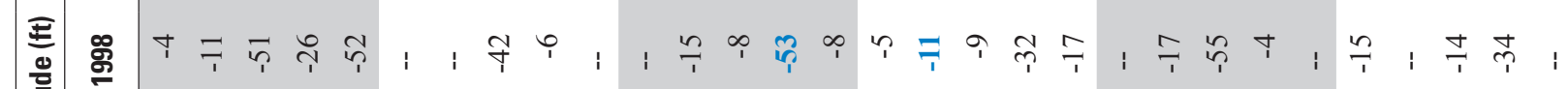

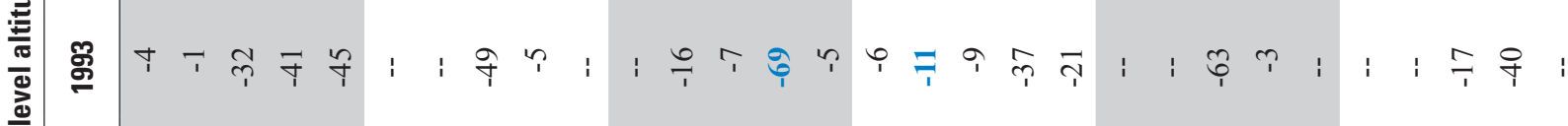

咅

骂 $1 \frac{0}{1}+\frac{n}{1}$ 令

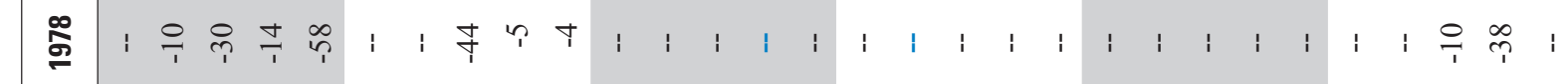

t:

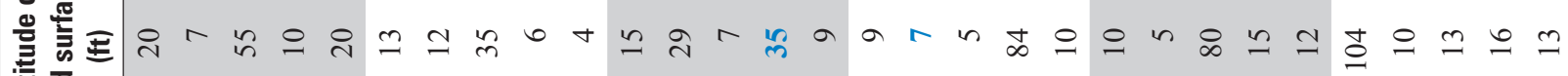
焉

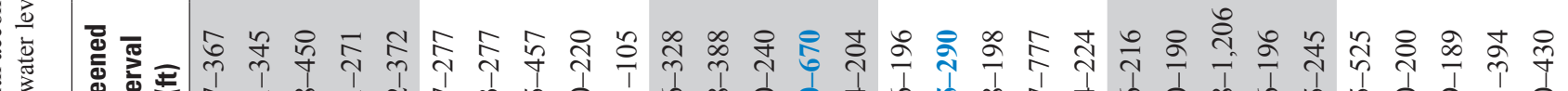

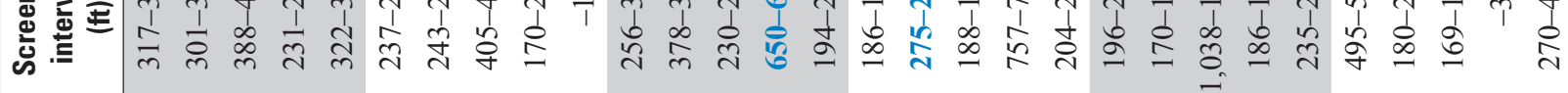

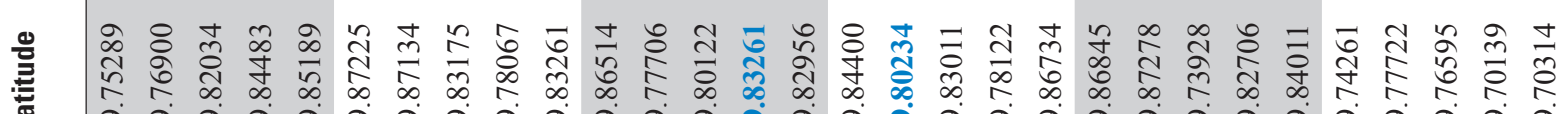

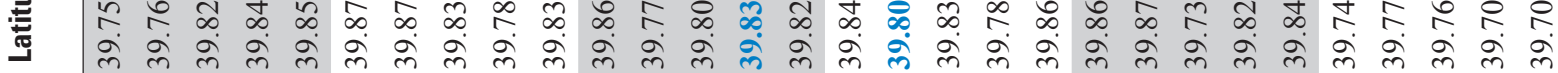

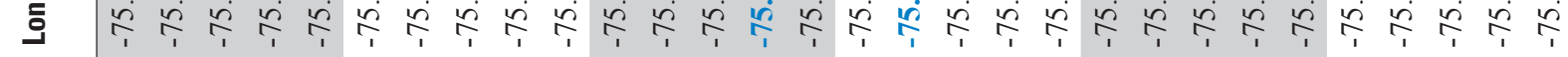

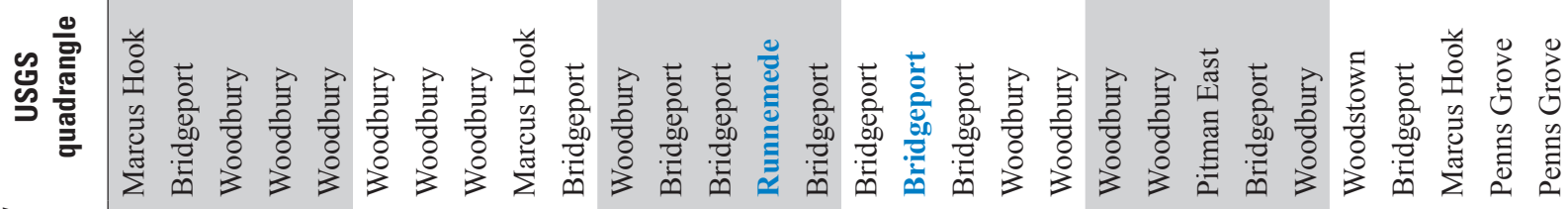

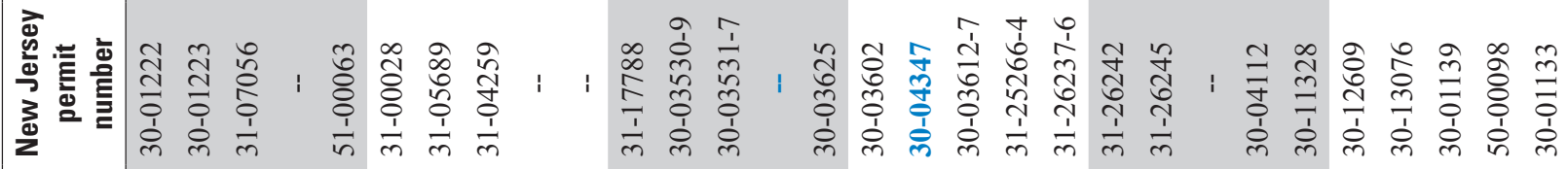




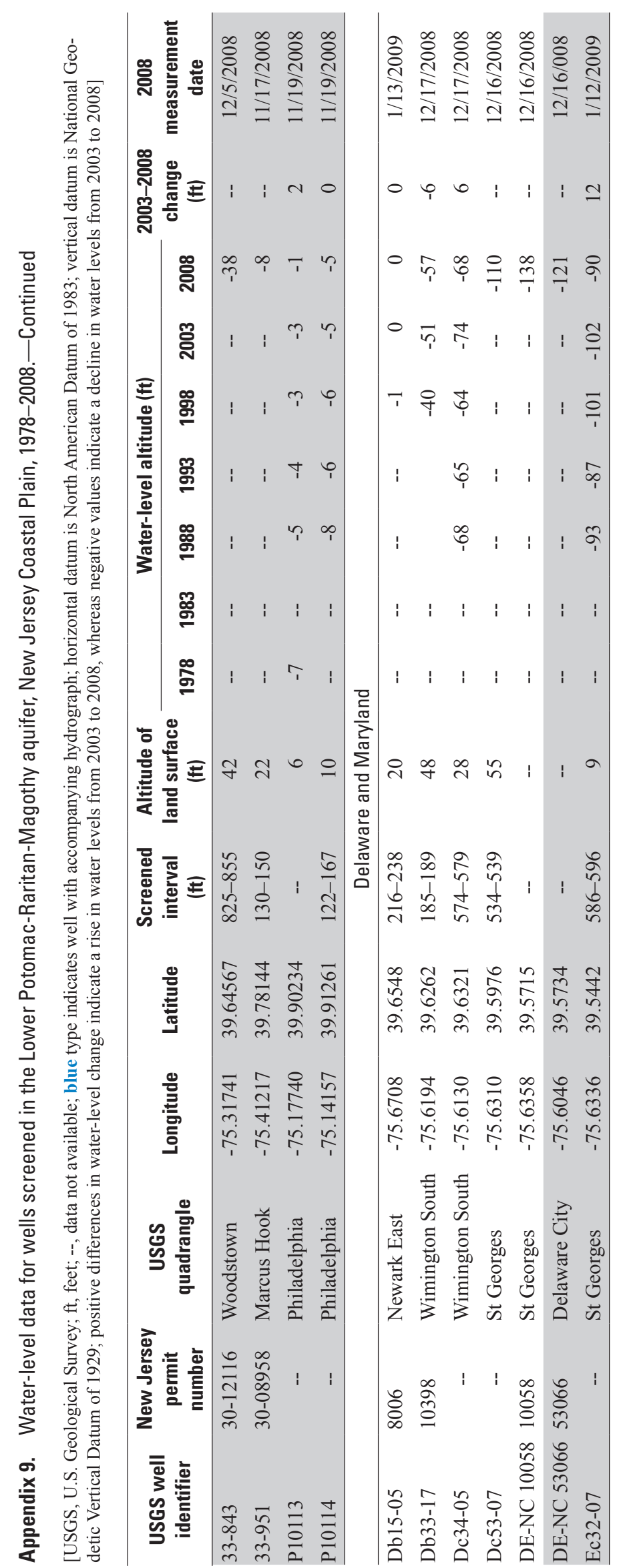




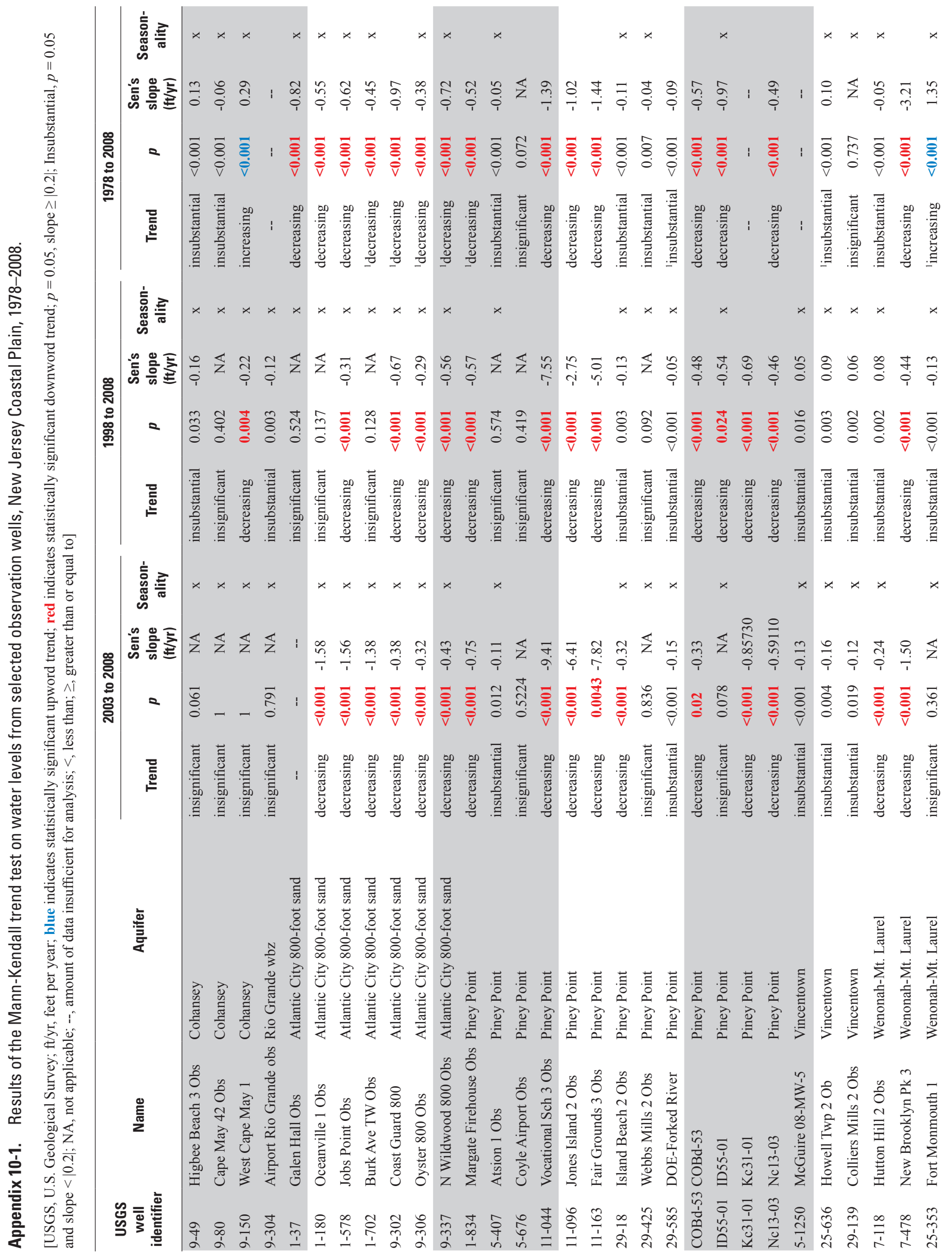




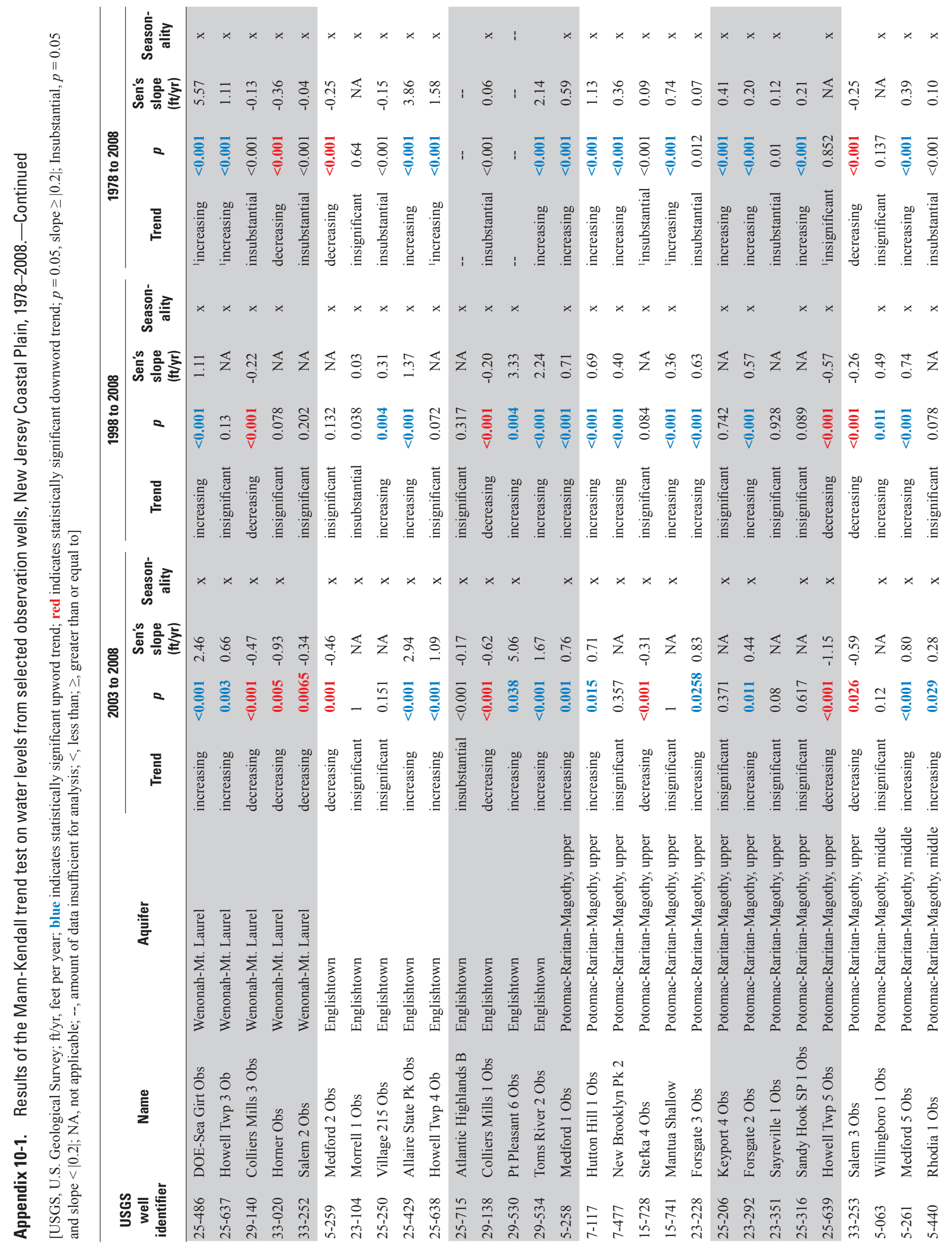




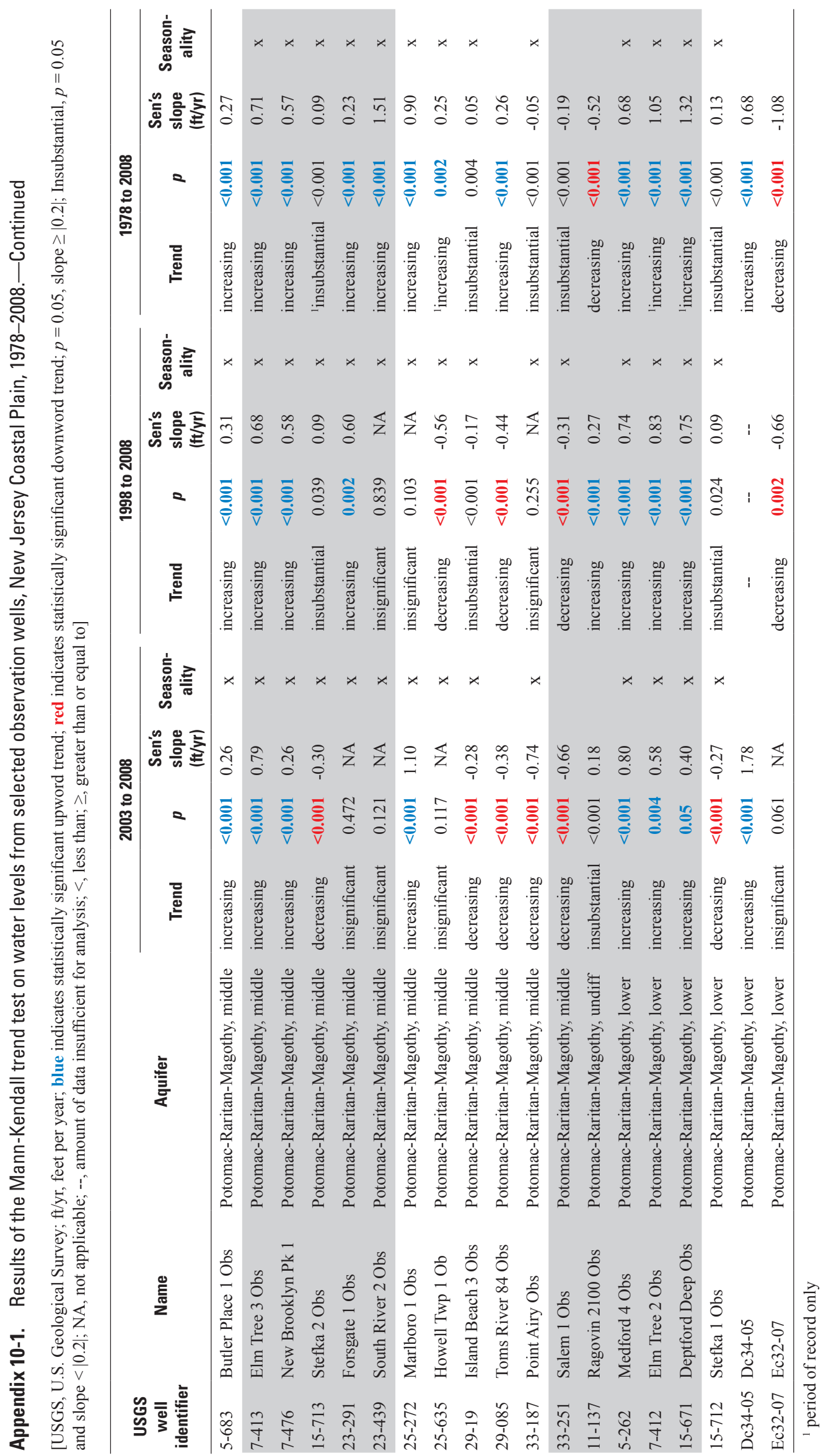




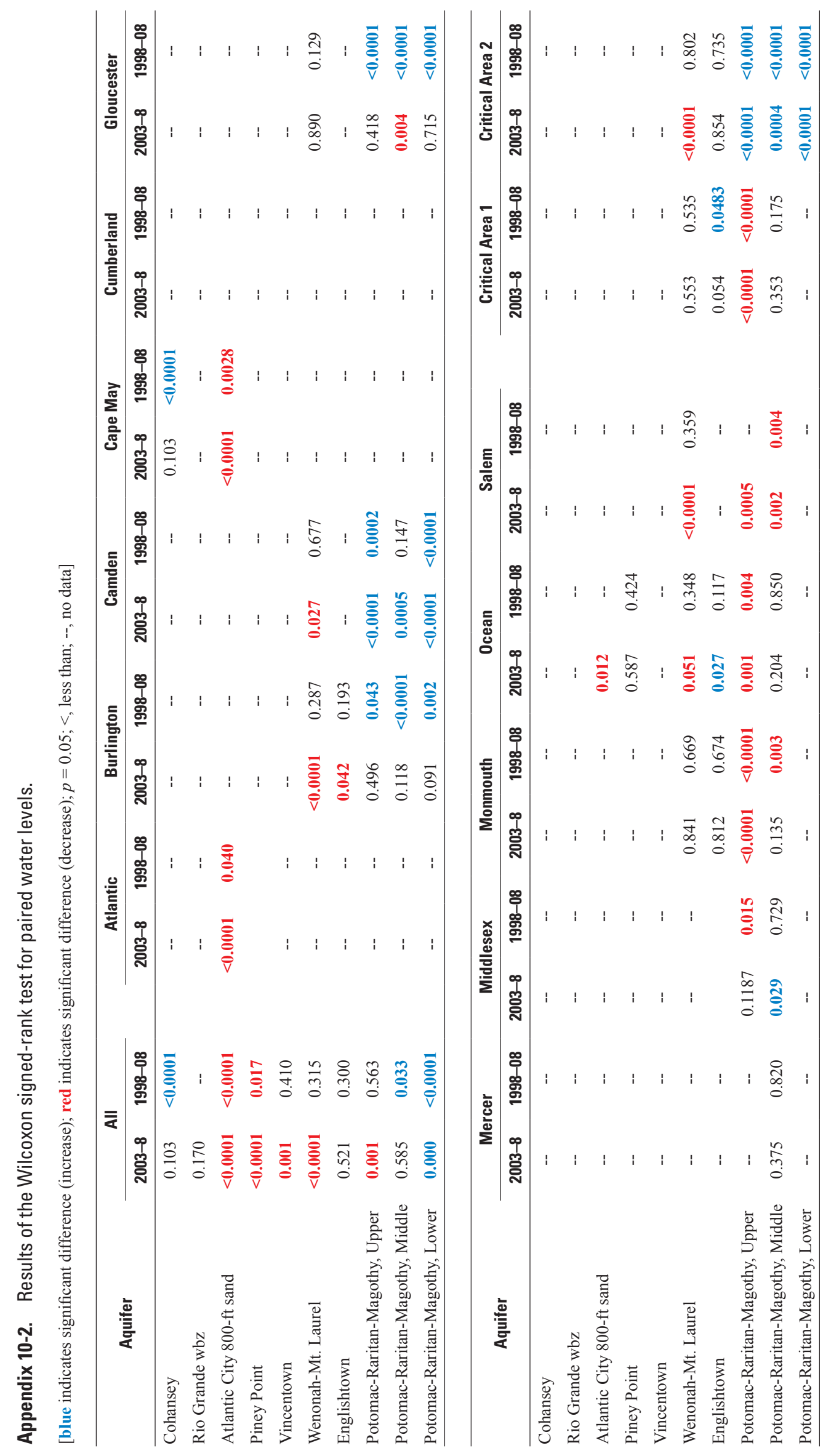


Prepared by the West Trenton Publishing Service Center

For more information, contact:

New Jersey Water Science Center

U.S. Geological Survey

3450 Princeton Pike, Suite 110

Lawrenceville, NJ 08648

http://nj.usgs.gov/ 
